

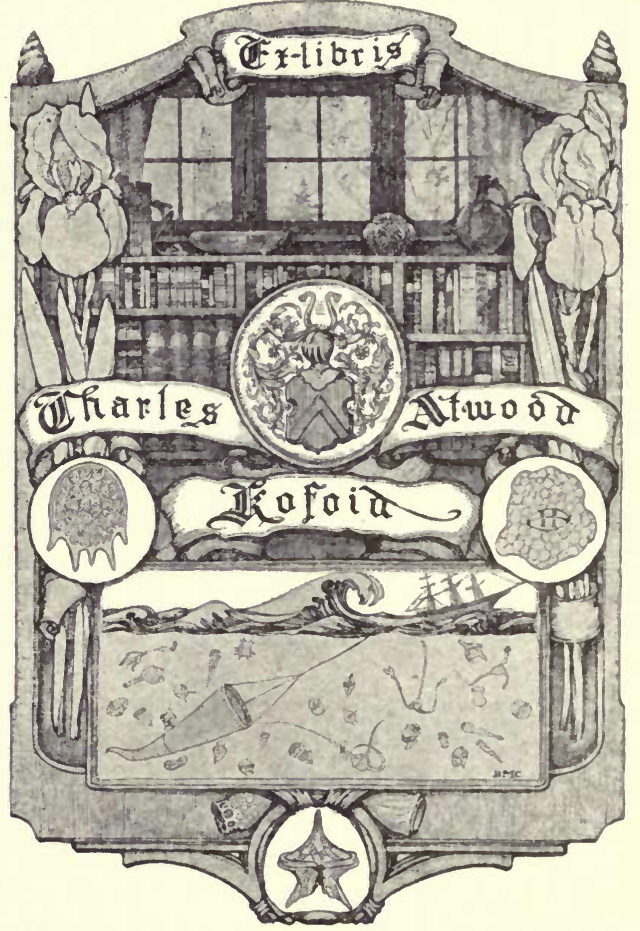




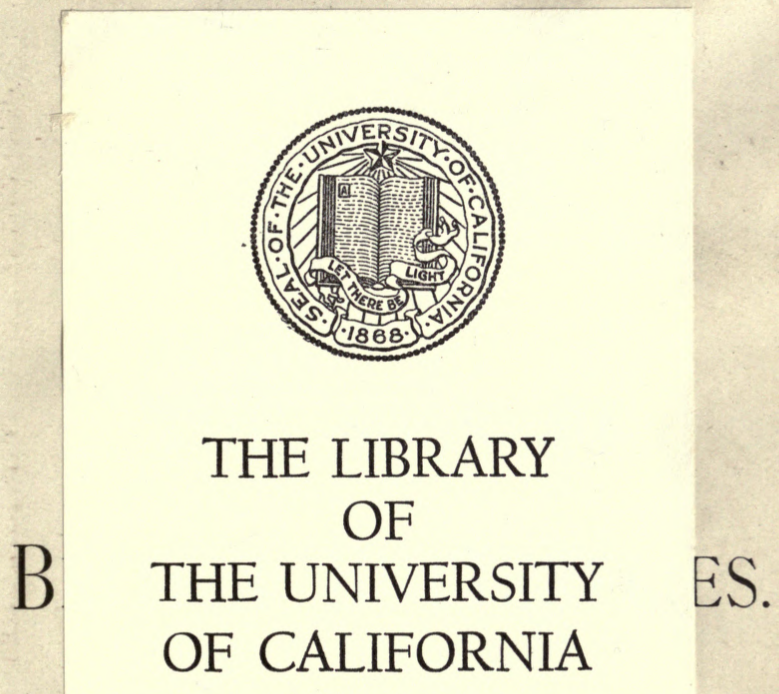

PRESENTED BY

PROF. CHARLES A. KOFOID AND MRS. PRUDENCE W. KOFOID 



\section{THE BOOK OF}

\section{BRITISH BUTTERFLIES.}

A PRACTICAL MANUAL FOR COLLECTORS

AND NATURALISTS.

By W. J. LUCAS, B.A.

WITH ILLUSTRATIONS BY THE AUTHOR.

LONDON :

L. UPCOTT GILL, i7o, STRAND, W.C.

1893. 


$$
\begin{aligned}
& \text { LONDON : } \\
& \text { A. BRADLEY, LONDON AND COUNTY PRINTING WORKS, } \\
& \text { DRURY LANE, w.c. }
\end{aligned}
$$




\section{$K-Q L 555$ G7L7 Bul}

PREFACE.

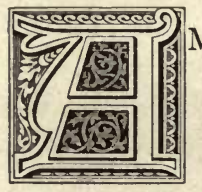

MONG the many beautiful objects which the student of Nature finds awaiting his attention, the Butterflies will be allowed by most to take a very prominent place, adding as they do another to the many charms of the flower-decked summer-fields. To assist the large and ever-increasing body of naturalists who make Butterflies their pursuit, "THE BoOK OF BRITISH BUtTERFLies" has been written. Though primarily intended for beginners it is not a book for mere collectors only, but one that will assist, it is hoped, those who take up the subject in the true entomological spirit-a spirit that seems to be on the increase at the present day-one that speedily transforms the collector into an observing and experimental entomologist.

With this ${ }^{\circ}$ object in view, while $a^{\circ}$ popular style has been employed and abstruse matter has been studiously avoided, the subject has been treated with sufficient fulness, it is hoped, to enable anyone wishing to do so, to work at these insects in all stages of their life-history. It might be thought perhaps that the Butterflies are thoroughly worked out already, but this is quite a mistake, and the lover of this grand division of lepidopterous insects will find that, as in all other.cases, the further he goes the more there is to learn. 
Of the earlier life-history of many species we have very indefinite and unsatisfactory knowledge - of some, indeed, we know scarcely anything, even of the best known our knowledge is none too perfect. In this department then, the aspiring naturalist has a wide field before hima fact which he indeed might perceive from the gaps that occur in the present volume.

A great feature of this book is the number of illus. trations. Most of the figures of the imagines, both upper and under-surface, were made from the author's drawings of the insects, but in some cases they were prepared from photographs taken direct from nature, the insects in the latter case being kindly lent by Messrs. Watkins and Doncaster of 36 , Strand. As often as possible the figures of larvæ and pupæ were drawn from actual specimens; but where these could not be procured assistance was obtained from Buckler's "Larvæ of the British Butterflies," published by the Ray Society; the larva of Danais erippus was taken from a cut that appeared a few years since in The Entomologist.

Descriptions of the larvæ and pupæ have been compared with those of Buckler, Newman, and others, and assistance sometimes was obtained from the same sources. The periodicals on the subject have frequently been laid under contribution, and the last twenty-one years of The Entomologist carefully searched to see how far the records there agreed with the usually given lists of localities. The order, nomenclature, and synonymy of genera and species are those of South's new "Entomologist Synonymic List."

KINGSTON-ON-ThaMES,

$$
\text { W. J. LUCAS. }
$$

June, 1893. 


\section{CONTENTS.}

СHAP.

I.-INTRODUCTION $\quad \ldots$.

II.-PAPILIONIDA.

III.-NYMPHALID

IV.-LyCæNIDE • • . . . . . $\quad$ I64

V.-ERYCINIDE .

VI.-HESPERIIDE . • . . . . . 208

VII.-Collector's Calendar • • • • 224

General Index • . $\quad . \quad$. $\quad$. 239

INDEX OF FOOD-PLANTS . . . . 244 



\section{THE BOOK OF}

\section{BRITISH BUTTERFLIES.}

\section{CHAPTER I.}

\section{INTRODUCTION.}

\section{The Butterfly's Place in Nature.}

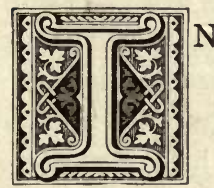

N commencing a popular account of our British butterflies, it will doubtless not be labour wasted if a few lines are devoted to the consideration of what a butterfly. is, and to pointing out its proper position in the scale of animal life. Indeed, this seems not only expedient, but absolutely necessary, seeing that a curious, but at the same time very general, idea prevails that the term "animal" cannot properly be applied at all to butterflies and other of the smaller creatures that live and move and have their being upon the earth. Those who possess this idea are not, of course, students of Nature; for it would be impossible to turn over many pages in her book without discovering that all these creatures, however small, however simple, are endowed 
with a tiny spark of that same unfathomable mystery-life - which reaches its highest manifestation in man himself.

Our subject, then, is a branch of biology, ${ }^{*}$ the science that treats of life in its widest sense; but this com. prehensive science has two sides, which treat respectively of life as it is manifested in animals on the one hand, and in vegetables on the other. It is needless to say that we are concerned with the former alone-the animal or zoologicalt side.

Varied as are the members of the Animal Kingdom, they may all be grouped into eight sub-kingdoms, the highest of the eight containing the vertebrate + animals, that is to say, those which possess a backbone and internal skeleton; while the animals composing the other seven are invertebrate, having no internal skeleton. Butterflies are found among the Arthropoda, $\S$ the most advanced of the invertebrate sub-kingdoms.

The Arthropoda contain four classes, the most highly organised being the Insects, $\|$ which may be distinguished by their arriving at maturity after a series of changes, called metamorphoses, when the outer covering is cast off and a creature appears, as a rule utterly unlike what it was before the change. An insect in the perfect state may further be known by its being enclosed in a jointed envelope and by having its body divided into three parts: the head, bearing antennæ, eyes, feeding apparatus, \&c.; the thorax, bearing six jointed legs and four wings; and the abdomen. Butterflies fulfil these conditions and are therefore insects. It should be observed

* Bíos (bios), life, $\lambda{ }^{\prime}$ yos (logos), an account, a description.

$+\zeta q$ ov (zoon), a living thing.

$\$$ Vertebra a joint.

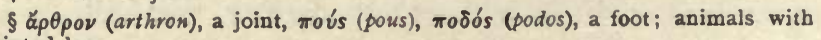
jointed legs

|| Insecta, divided into (segments). 
that we are using the word "insect" in its strictly scientific sense. The term is often employed in common parlance in a very loose way, such animals as worms and spiders being not seldom spoken of as insects. A glance will shew that they do not comply with the description of an insect given above. The busy little creature that elaborates the coral is another favourite subject for the same misnomer.

Thirteen natural orders comprise the class Insecta. The members of the highest order but two have received the scientific name of Lepidoptera, ${ }^{*}$ or scale-winged insects, and are characterised by having four large wings covered with small coloured scales overlapping like the tiles on the roof of a house. Further, the pupæt are inactive, that is, do not move about or feed, or indeed shew signs of what is called active life, except sometimes an impatient wriggling of the anal extremity under irritation.

The lepidopterous order of insects is divided into two sections, the-Rhopalocera ${ }_{\ddagger}^{+}$and the Heterocera§. The former section contains the butterflies, $\|$ with "horns" (antennæ) more or less club-shaped ; the latter, the moths, whose "horns" of whatever shape they may be are never clubbed.

It is not always easy at a glance to distinguish between butterflies and moths, but it is satisfactory to know that butterflies cannot possibly be confused with any other class of animals except moths, and to prevent confusion with them the following points of difference should be

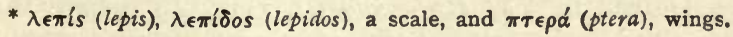

$+P u p a$, an undeveloped being.

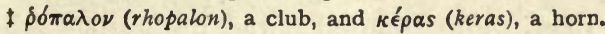

$\S$ єै $\tau \in \rho o s$ (heteros), other, different.

$\|$ From the Anglo-Saxon buttor-fleoge = butterfly. So named probably from the excreta of some species resembling butter, or may be in reference to the colour of some of the commoner kinds. 
noticed. In the first place the former all fly by day, while most of the latter fly at night. Again, the flight of a butterfly is in a wavy line-it flutters, as we saywhile most moths fly in a straight line, and often with great speed. All our butterflies (except the Skippers) repose with the wings meeting perpendicularly over the back, so that the upper surface is hidden; while most moths repose with the wings arranged roof-like over the body, disclosing the upper surface of the forewings, the hind-wings being hidden beneath them. Again, while it is the rule with moths to spin a cocoon for the chrysalis-state, true butterflies never do so, though the Skippers (which, however, resemble moths in many respects) pass that state in a more or less transparent net of silk. But the most satisfactory point of distinction between a butterfly and a moth is to be found in the antennæ-horns, as they are popularly called. The tips of the antennæ of a butterfly are clubshaped, giving each antenna somewhat the appearance of a miniature drumstick with a very long handle; but the antennæ of moths, on the other hand, though variously shaped, always come to a point at the end. Moreover a butterfly, when at rest, keeps its antennæ erect or stretched out in front of its head, whereas a moth bends them back and places them close along the sides of the thorax. But in connection with the last point it will perhaps turn out when more is known about the matter, that the group of butterflies known as Skippers fold back their antennæ in the way just mentioned. Indeed in The Entomologist, xvii., 49, where the sleeping position of Nisoniades tages (Dingy Skipper) is admirably described and figured, we find that the antennæ are represented resting along the thorax in the manner generally adopted by moths, as noted above. 
Synopsis of the Butterfly's Position among Animals.

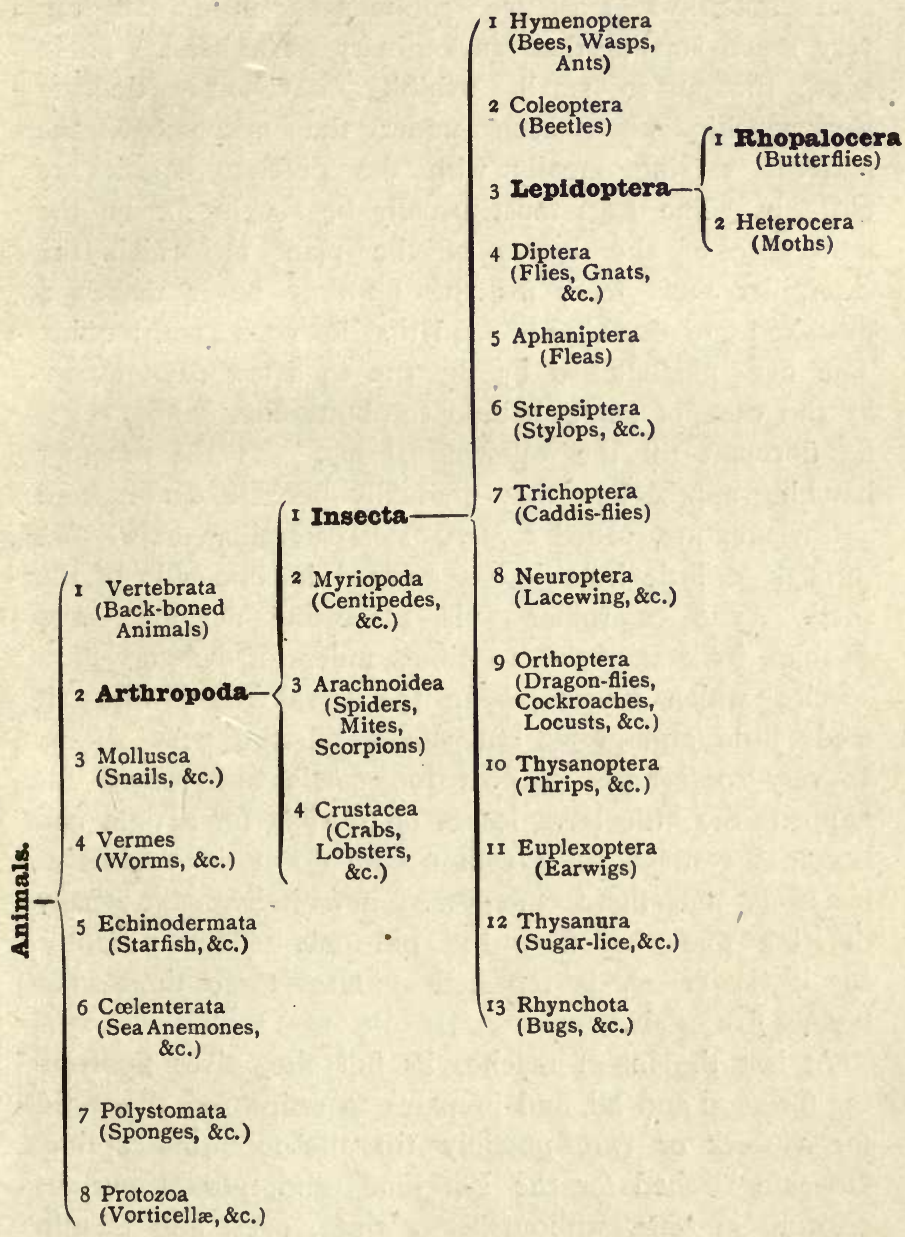




\section{Life-history of a Butterfly.}

A butterfly's existence commences inside an egg very much smaller than an ordinary pin's head. These eggs, though so small, exhibit marvellously delicate workmanship when seen under the microscope, the patterns varying greatly with the different species of butterfly. The eggs must usually be sought for on the under-side of the leaves of the plant on which the caterpillar must feed, for the butterfly never makes a mistake as to the kind of food that its young will require. The eggs are hatched by the sun in a few days, except in the case of some half-dozen butterflies, whose eggs lie dormant till the following spring. As the time for hatching approaches, they gradually become darker, and a tiny creature, called a larva, ${ }^{*}$ or caterpillar, crawls out through a little hole it has gnawed in one side of the shell. The caterpillar falls to eating at once, and doubles its weight in no time, unless it belongs to a species which hibernates in the larval stage, when it feeds little and grows but slowly till the next spring. It very soon finds its coat too small, and when this happens the little larva leaves off feeding for a time and becomes restless, till a split occurs down the middle of its back, and there emerges a new individual, usually differing somewhat from the old one. This "moult," as it is called, is repeated at least three times, but oftener five or six.

At last the insect reaches its full size, gives up feeding for good and all, and prepares to retire from the world for a week or two, possibly till the following spring. Its skin is shed for the last time, and now a curious creature appears, without legs, wings, eyes, and mouth, 
entirely closed up in a horny case, powerless to move, except just to wag the hinder segments of the body. This helpless mummy-like object is called a pupa, or chrysalis. The pupa may usually be found fastened by silk of the larva's spinning to a wall, the food-plant, or some other convenient object.

Usually after from ten to twenty days the last change takes place, the thick end of the pupa splits open in several directions, and the perfect insect, called an imago,* or butterfly, emerges, with large body and tiny, damp, and rumpled wings. The butterfly suspends itself by its legs, and begins shaking out its wings. In an hour or so they have attained their full size, and carry their owner off to enjoy its few weeks of sunny existence. All that the insect has now to do is to flirt awhile, and, if a female, lay eggs before it dies, except in the case of a few species, which sleep through the winter, and, when warm days return with the spring, appear again to reproduce their kind.

\section{Butterfly-hunting.}

It is a bright sunny morning in June, with very little wind stirring, and what there is of it coming from a westerly or south-westerly direction-a morning as inviting to the butterfly-hunter as it no doubt is to the insects he would like to capture. Let the former sally forth with the expectation that if butterflies, due at that time of the year, are to be found in his district, he will have a fair hope of taking them. He need not reach his hunting-ground much before nine, for very few butterflies are on the wing earlier than that; nor, however enthusiastic he may be, will he find it of much use to remain

* Imago, distinct and perfect form. 
out later than half-past four or five, though he will doubtless always find a few individuals on the wing almost from sunrise to sunset.

In general the best spots for butterflies are clearings in woods, or meadows and pathways by the side of them. Some butterflies, such as the Purple Emperor, the White Admiral, the Wood White, the Purple Hairstreak, and many Fritillaries, are scarcely ever found elsewhere. Several, among them being most of the Whites and Vanessas, are friendly enough to visit us in our streets and gardens. Many are common everywhere, others are equally scarce, while some again are local, that is, only to be found in particular spots, though often plentiful enough there. A few haunt marshy places, some must be sought for on heaths, others again prefer the chalk, and one or two are found upon the mountains; in fact, it would be hard to name many spots in a state of nature and to which the sunshine can penetrate, where butterflies of some kind are not to be found.

In dull weather, or when butterflies have retired for the night, they may often be found in their sleepingplaces, though it usually needs a sharp eye to detect them there, for most, if not all, sleep mid surroundings with which they harmonise so well that they are easily passed over on a cursory glance. This is especially the case with the Blues, the Small Copper, the Marbled White, the Orange-tip, and the Vanessas.

The only apparatus required for use in the field are a net to catch the butterflies, and a box or boxes of some kind to hold them when caught.

The most convenient form of net is the ordinary ringnet (Fig. I). The bag is made of gauze, eithęr silk or cotton. If the latter material be used, it must first be well washed to remove the glazing that gives stiffness to 
it. Most people affect green, though white is sometimes used-I prefer the former, as being less conspicuous to an onlooker, if not to the butterfly. 'The bag should be a little shorter than one's arm, so that the bottom may be easily reached, and should on no account end in a point, or butterflies will seem to take a delight in finding their way there, and require a great deal of getting out, to the almost certain damage of their plumage. The bag must be fastened to a ring of cane or stiff wire, and this again firmly fixed to a handle at least as long as an ordinary walking-stick. The top of the net had better be bound with some material stouter than gauze, or it will very soon be torn away from the ring. It is especially important that the net should be firmly made, for nothing is so tantalising as to lose a good insect in consequence of the net falling to pieces at the moment of striking.

Many entomologists have a dislikeno doubt a natural one-to be seen in the streets of a town carrying a net to the field of operations, so dealers in natural history requisites supply nets of various kinds that can be folded up

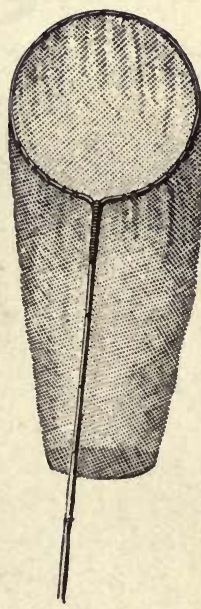

FIG. I.

Gauze RING-Net. and put out of sight. The most convenient one, in my opinion, consists of a three-jointed cane ring (Fig. 2) on which the hem of the net slides, the parts being hinged together and finished with brass fittings. The ends of the ring fit into the two forks of a brass $Y$-tube, while a walking-stick fits into the stem. This net is a very neat affair, and can be thoroughly trusted to do the work required of it. I 
have had such a one in use for several years, and it is still in good working order. The best method of wielding the net will be learnt from experience. The novice will not be long in discovering that it seldom
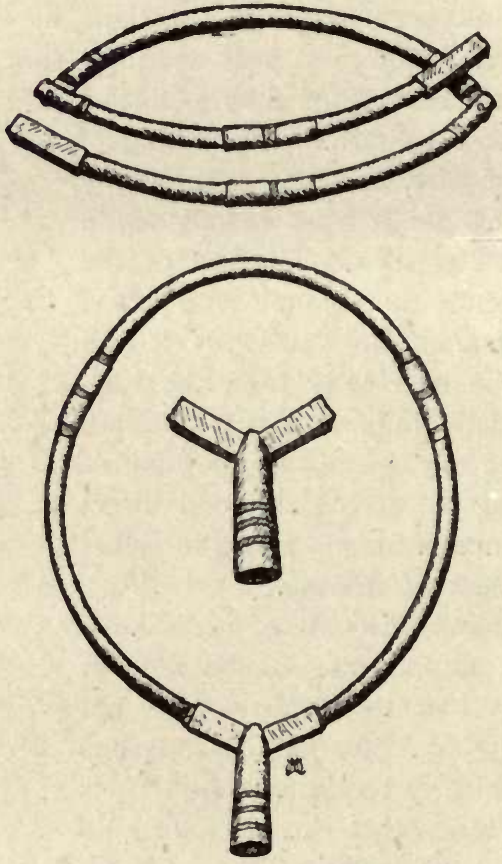

Fig. 2. Mechanism of Folding Ring-net.

pays to try to chase a butterfly down. In the majority of cases it is much better to watch it to its resting-place, and try and take it there. Should a successful stroke be made and the butterfly caught, a sharp turn of the wrist will close the net and keep the insect a prisoner. 
We have next to kill the butterfly. No attempt must by any chance be made to touch it till it has ceased fluttering and closed its wings over its back. Then a sharp nip of its body at the insertion of the legs, given by means of the finger and thumb, usually settles the matter, or at least renders the insect quiescent. This nip can be given through the gauze. The butterfly may now be allowed to fall from the net into the open hand, and a proper entomological pin must be thrust carefully and in a perfectly upright position through the very centre of its thorax.

If the collector does not mind the trouble of taking a cyanide-bottle to the field, he can kill his captures before handling them at all. To make a cyanide-bottle, a wide-mouthed stoppered bottle, holding about $5 \mathrm{Oz}$. or $60 z$., should be procured, and about $\frac{1}{4} \mathrm{Oz}$. of potassium cyanide $(\mathrm{KCN})$ put into it. Next a somewhat thin paste of plaster of Paris and water should be made, and poured over the potassium cyanide till there is a layer about rin. deep. When this sets, the cyanidebottle is made. But as one can be purchased for a small sum, and potassium cyanide is exceedingly poisonous, it is perhaps as well to buy one. The poisonous vapour of the cyanide (smelling somewhat like almonds) penetrating the layer of plaster of Paris stupefies and finally kills the butterfly placed in the bottle.* Insects bred at home had better always be killed by this means.

Some of our readers might like to make a killingbottle by folding a piece of cyanide in paper, and securing it by means of sealing-wax or other adhesive to the bottom of a bottle. As, however, in this case, the poison is more readily accessible to inquisitive fingers, care should be taken to keep the bottle out of harm's way.

\footnotetext{
* The vapour, being exceedingly poisonous, should not be breathed.
} 
The butterfly, then, being killed by one means or the other, and properly pinned, must then be placed in a collecting-box. These had better be bought, as they are very cheap indeed, and an amateur would probably not succeed very well in making them. They are light deal boxes lined, either at the bottom only or at both top and bottom, with cork. It is of course an advantage to have them as large as possible consistent with going easily into the pocket, and, if both top and bottom are going to be used, care should be taken that they are deep enough to prevent the pins on one side from destroying the insects on the other.

On a hot day the small butterflies sometimes begin to get stiff before they can be taken home to the setting-boards; or in the height of the season the numbers taken may make it impossible for all to be set at the time. To obviate this difficulty the dealers sell zinc relaxing-boxes. These are cork lined: hot water is poured over the cork and the superfluous moisture wiped away; the little moisture remaining in the box keeps the air inside damp for some time. These boxes will not, however, be often needed in the field, and never for the larger butterflies. Others again prefer to take their specimens home alive, each in a small box, and this of course is imperative if there is at any time a desire to obtain eggs from a captured female.

\section{Breeding.}

There is another way of procuring perfect insects-by breeding them; and there are three-stages at which breeding may be commenced, from the egg, from the larva, or from the pupa. The last is the simplest-all that has to be done is to keep the pupa as nearly as possible in a state of nature and wait till the imago 
appears; then a few hours later to kill and set it. If breeding from the egg is going to be tried, the eggs must be attached to the food-plant, so that the food may be at hand as soon as the larvæ come out. Of course caterpillars thrive best on actual living plants, and they may often be left to themselves on one without much fear of their moving from it until the time for pupating draws near. If it is not thought well to give them carte blanche in this way, a bag of gauze may be tied over them and the branch on which they are feeding. In the event of the food-plant being small, it is an excellent plan to have it growing in a flower-pot, covering the whole either with gauze or with a glass cylinder capped with gauze.

If preferred, larvæ may be reared indoors in some kind of cage : a tin or chip box, or something of that kind, a few inches in diameter, and eight or ten inches high, will do very nicely. On the floor of this cage a couple of inches of fine earth or sand had better be strewn. In the centre of this layer of earth should be placed a narrow-necked bottle containing a sprig of the food-plant. A little cotton-wool round the stem will make it fit the bottle, and so remove the chance of small larvæ being drowned. About a dozen eggs having been fastened on the sprig, the top of the cage must be covered with gauze to prevent the escape of the larvæ. It is as well, if a tin box is used, to make the inside of it rough, so that the caterpillars may be able to reach the food-plant again should they fall from it. The box may be roughened by smearing it with moist sand. When renewing the food-plant, the larvæ must on no account be lifted with the fingers: they should be shaken from the old to the new twigs, or at most, be lightly touched with 
a camel-hair brush. As the larvæ increase in size they must be separated to prevent overcrowding. When the time for pupating is near, the old twigs must be searched to see that there are no chrysalides upon them, for most butterflies, except the genus Pieris, pupate on the stems or on the backs of the leaves of the food-plant, or, in the case of a few butterflies, at their roots. The cages I have just described should be the minimum as regards size, for the more room larvæ have, the better they thrive. Larger and more elaborate ones, in which a greater number of larvæ may live together, can be prepared on the same principle; or very neat and useful cages may be bought very cheaply at the natural history dealers'.

\section{Note-making.}

When breeding or collecting, let me recommend everyone to keep a note-book, and enter therein with the date everything that seems in the slightest degree worth recording. It may not appear of much consequence at the moment, but may perhaps be exactly the link needed to connect two chains of facts at a future date. This at once raises the pursuit of entomology far above a mere hobby; and since insects are to be found practically everywhere, and, though at times useful, more often cause us great inconvenience, if nothing worse, a simple discovery in connection with them might perhaps prove of inestimable benefit to the human race. Even if nothing else should result, it is always interesting to be able to refer at odd moments to some records of the past, and, like a soldier, on winter evenings to fight one's battles over again.

The following scheme, which may be amplified to meet individual requirements, will perhaps be of use to those collectors who keep a note-book, as suggested above: 
a. Description.

A. Egg.

I. Shape.

2. Colour.

3. Markings.

4. Size.

b. When laid.-Whether more than once a year-whether winter is passed in this state.

c. Where laid.-The plant, and what part of it.

d. How laid.-Whether singly, or in groups of how many.

a. Description.

B. LARVA.

I. Shape.

2. Colour.

3. Markings.

4. Size.

5. Smooth, or covered with hairs or spines.

6. Variations in these respects.

b. Food-plant or -plants.

c. Date of hatching-hibernation (if winter is passed at this stage).

d. Number of moults and changes at moulting.

e. Difficulties, \&c., experienced in breeding.

a. Description.

$$
\text { C. Pupa. }
$$

I. Shape.

2. Colour.

3. Markings.

4. Size.

5. Variations in these respects.

b. Choice of place for pupating.

c. Method of support of pupa (cocoon, if any).

d. Date of pupating - hibernation (if winter is passed at this stage).

a. Description.

$$
\text { D. IMAGo. }
$$

I. Shape of wings and antennæ.

2. Number and use of legs.

3. Colour.

4. Markings.

5. Size.

6. Variations in these respects. 
b. Difference between male and female, and in what proportion taken or bred.

c. Date of coming out and ceasing to fly. Hibernation (if winter is passed at this stage).

d. If more than one brood, dates, and differences between them.

e. Manner of flying, favourite resting-places, time of day and state of weather when on the wing.

$f$. Localities, and local varieties, with causes, if possible.

g. Peculiar habits, \&c.

h. Parasites and other enemies.

\section{Setting.}

We will suppose we have a butterfly, freshly caught. How is it to be set? It will not, as many people seem to imagine, of its own accord arrange its wings and antennæ in such a way as to make it fit for the cabinet. We must first have setting-boards, which may either be manufactured by the collector or bought ready made. Since they are very cheap, it is better to adopt the latter alternative. Four or five sizes will be required in order to suit the size of the bodies of the different butterflies and the stretch of their wings. There are two types of setting-board: one with the surface of the slope curved, the other not. In the natural state, I suppose, a butterfly never does curve its wings; but, personally, I must confess I prefer a butterfly set on a curved setting-board, if the curve is not too pronounced. Vertical sections of the two types of board are given in Figs. 3 and 4 . It will be seen that they have a deal base covered with an upper surface of cork, and there is a strip of cork, about $\frac{1}{8}$ in. thick, glued along the groove that is to contain the butterfly's body. Some people manage to dispense with the cork, and use setting-boards made entirely of deal; but it is false economy-pins are easily blunted, and the slightest touch knocks them out of the wood, and in this way 
specimens are often spoilt even where the utmost care is exercised. The surface of the setting-board should be covered with a layer of unglazed white paper-plain cork will rub the under-surface of the wings. On the Continent setting-boards are not sloped, and the groove is very deep, so that the butterfly appears with its wings perfectly flat and fixed rin. or more up the pin, producing an effect which appears to me anything but agreeable. When buying foreign specimens of

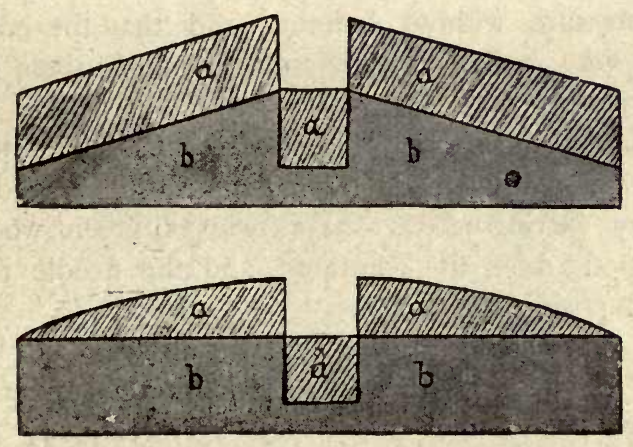

Figs. 3 and 4. Vertical Sections of Setting-boards.

$a$, cork; $b$, deal.

our scarcer English butterflies this should be recollected, and, unless specimens set in the Continental fashion are preferred, they should be asked for set in the English way.

The setting-boards being disposed of, we may next consider the question of pins. It is clear that for such a delicate subject as a butterfly's body, ordinary pins are altogether unsuitable, and the proper ones must be bought from a dealer in natural history requisites. Entomological pins are much more slender than the 
ordinary ones, and have very inconspicuous heads. They are made in all sizes, to suit all sorts of insects. Three very good sizes for most butterflies are Nos. 8, 9, and 10; but if they are going to be used for moths as well as butterflies, it is perhaps a good thing to buy them mixed. Plain white mixed pins are Is. an ounce, but they can be obtained for double the price gilt or covered with black enamel, and these are worth the extra cost, as grease will not act upon them. It must be remembered that entomological pins will stand very little pressure without bending, and that the points are turned very easily, even by trying to push them through glazed paper.

Setting-needles, for arranging the wings, antennæ, and so on, are readily made by inserting the eye-end of an ordinary sewing-needle in a twig of green wood. As the wood dries it contracts, and the needle is firmly held in position.

We now come to the actual setting. The butterfly should be held in the left hand by the under-side of the body, and the pin thrust very carefully through the centre of the thorax in a perfectly upright manner. This is very important, as in a case a badly-pinned butterfly spoils the look of a whole row. The insect is now put on the board with the body nicely arranged in the groove. If the abdomen does not dispose itself properly, it must be kept in position by pins stuck into the board. Now comes the difficult part of settingthe arranging of the wings without damaging them. Of course, the simplest thing to do would be to bring one wing into position and stick a fine pin through it; and so on until all four were arranged. No doubt, in many cases the holes so made in the wings would not be apparent; but in others they most certainly would, so 
another method must be found. Many use triangular slips of thin, smooth cardboard (Fig. 5), and as soon as a wing has been carefully drawn into position with the setting-needle, one is pinned down over the margin to keep that wing in place till the others are arranged in the same way. A very good method, which is illustrated in Fig. 6, is to have some square pieces of cork with a shoemaker's bristle thrust through each somewhat obliquely. The cork is fastened to the setting-board with a pin, and the bristle will then be found to

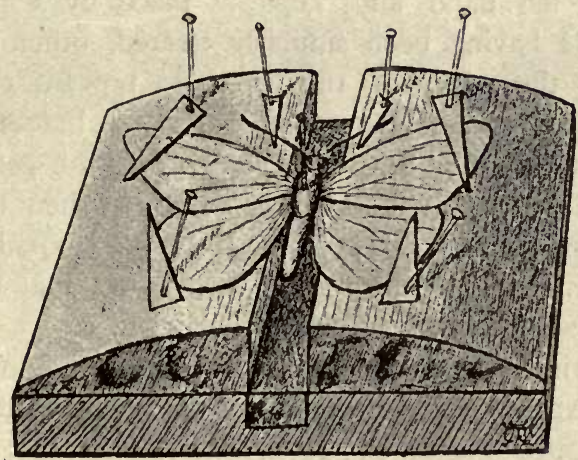

Fig. 5. Method of Setting with Cardboard Braces.

exercise considerable pressure on the board, and will hold the wings in the same manner as the cardboard slips. It has this advantage-that it does not hide the wings or interfere with the braces that are to come afterwards. It is extremely important to be able to see all the wings well at once to ensure their being arranged symmetrically.

Others use a piece of quill for the same purpose and in the same way, the quill of course having the curved surface on the butterfly. 
My own plan is quite a different one. After the butterfly has been pinned in the groove, a small strip of paper (called a brace) is taken and one end pinned down, as in the lower part of Fig. 6, over the costal margin of one of the fore-wings. Next holding the other end of the brace between the thumb and first finger of the left hand, the two wings on one side are carefully disposed by the aid of a setting-needle held in the right. When both wings are thus drawn into position, the strip of paper is brought down over them with the left hand and kept in place by a pin. The other side having been similarly treated, other strips are put over the edges of the wings to prevent their curling as they dry. In my opinion, these braces are best made of transparent tracing-paper, so that the general outline of the butterfly may be seen through them (as shown in the lower part of Fig. 6). It is then possible to be quite certain, when the setting is finished, that the wings on the two sides are properly balanced.

The wings being arranged, the abdomen and antennæ must next be very carefully attended to, and held in their proper places by pins. The legs, too, of those butterflies that are intended to show the under-surface will require attention, for it looks very untidy to see all the legs pointing in different directions. The legs, by the way, are very easily broken off.

But one step now remains - to dry the butterflies that have been set. They must be kept out of the dust, and should, if possible, be placed in a current of air. Drying-houses made for the express purpose may be bought, but the expense is considerable, and they seem to me to be quite unnecessary for the ordinary collector. Everybody with a little searching can find a safe place for his setting-boards; but he must recollect that cock- 
roaches and other animals, to which the body of a butterfly seems a dainty morsel, have wings as well as legs. Cockroaches no doubt are good things in their

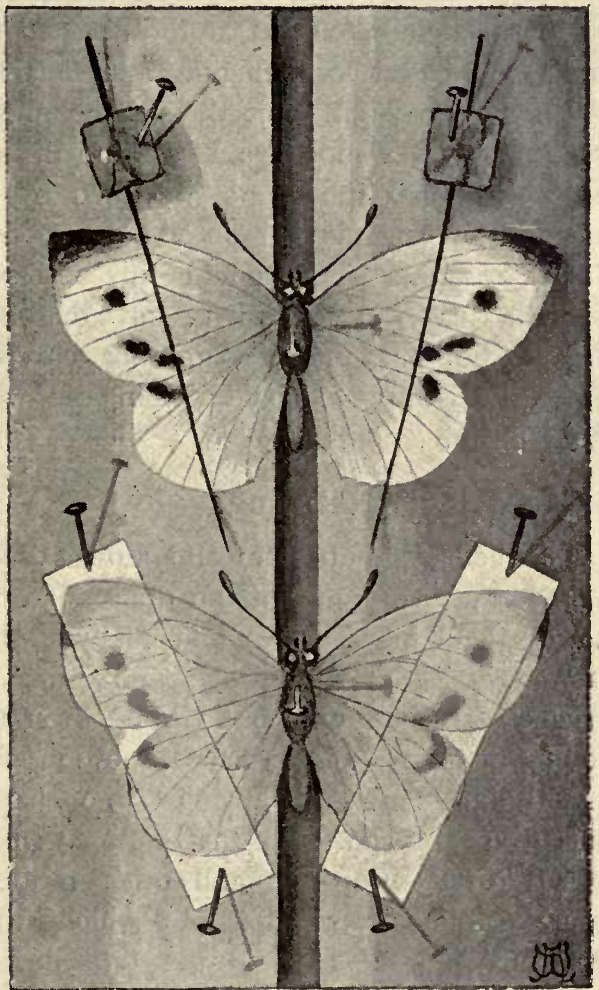

Fig. 6. Methods of Setting Butterfles with Bristles AND PAPER Braces.

proper place, wherever that place may be, but it is certainly not on the setting-board of an entomologist, and their presence must be carefully guarded against. 
Unless the air is damp, the butterflies will be dry in about a week; the large ones may take a little longer time, and the small ones a little less, but no harm is ever done by leaving them too long on the settingboard. I have generally found that those set to shew the under-surface are better for being a little longer on the boards. When time is an object, as sometimes on the last day or so of a holiday, I see no reason why butterflies (not moths) should not be dried by heat. I have made use of this method on one or two occasions, and no harm resulted. This should only be resorted to, however, in a case of necessity, and the butterflies should never be put on a board not covered with paper, for resin is apt to exude from the wood and fasten them down.

\section{Relaxing.}

Many a collector of butterflies and moths, especially if he is a novice at his craft, will no doubt find when he begins to overhaul his captures that many of them are not set as nicely as he would wish, and it may be that in the height of the hunting-season some even were put away without being set at all. The question will arise, what should be done by anyone who happens to find himself in this position, that he may make presentable his Purple Emperors and other rarities which he certainly cannot do without, but which with equal certainty he may not be able to put into the body of his collection in their present condition?

The first thing to do with a butterfly that requires re-setting is to relax it; that is, to reduce its wings, antennæ, and so on, to the same "lax" condition as they were in when the animal was alive. Drying an insect means getting rid of all moisture from its 
system; it is clear then, that in order to relax one, water must be re-introduced. In the case of a beetle, this is easily done by putting it into warm water for a few moments; but this treatment is much too rough for the delicate wings of a butterfly. It must be placed instead in moist air, warm by preference. There are zinc boxes made for this purpose, and to be bought at the dealers' for about a couple of shillings. These are lined with cork, hot water is poured over the cork, the superfluous water wiped off, and the butterfly shut in. Another method is to put the butterfly into a tightly-closed vessel containing bruised young laurel-leaves. But these two plans are more suitable for keeping re. laxed insects that cannot be set directly they are caught, than for relaxing those that have become thoroughly dry. In dealing with the latter I prefer to act as follows: place on the bottom of some vessel, such as a pudding-dish, or something of that kind, a layer of moistened sand that has been thoroughly baked to kill all vegetable and animal germs. Over this, but not touching it or the sides of the vessel, place the butterflies to be relaxed. Put a fairly close-fitting cover over them, and stand the whole in an oven that is getting cool. In this way the insects will be relaxed with comparative speed and, it seems to me, with less detriment to their appearance. Insects that have been relaxed must be left on the setting-boards longer than those that have been freshly caught, or they are apt to spring to their old position. In every case strict watch must be kept to prevent mould from growing on them while they are damp. Before leaving this part of the subject, I would say, never relax an insect if possible, for it is almost certain to lose some of its freshness, even if nothing worse befall it. 


\section{Butterflies in the Cabinet.}

The butterflies being caught and properly set, What is to be done with them? Shall they be arranged in a glass-topped case to form some elaborate design - gorgeous and beautiful, no doubt, to anyone who can forget the waste of life necessary to produce it-and leave them there to lose their colours from exposure to the daylight? But such a question need scarcely be asked; for every true entomologist will be too careful of his captures to treat them thus. He knows that if he wishes to preserve their rich colours he must keep them in darkness. Moreover,

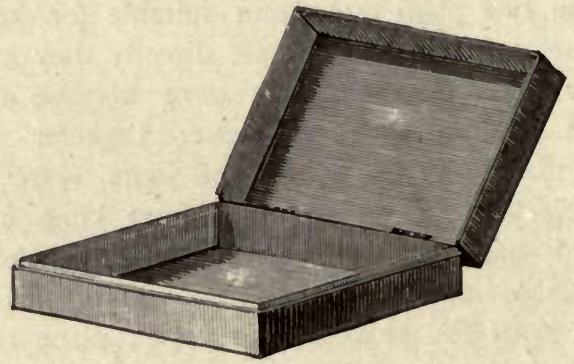

F1G. 7. STORE·CASE.

each insect will have to him an individuality which must be preserved-not lost amidst a blaze of splendour.

To attain these two objects - preservation of colour and individuality - a cabinet or cases of some kind must be provided. A beginner probably will not at first be so ambitious as to think of the former, but will for a time, at least, content himself with the latter. He may perhaps aspire to a properly-constructed cabinet at a later date, when his collection approaches completion; but he need not do so even then, for he can preserve it very well indeed in neat store-cases (Fig. 7), which can be pur- 
chased very cheaply. We will, however, say this much about cabinets : to be of any use they must be thoroughly well made, and that by some one who understands their use. Cheapness is therefore out of the question-so much so, that a good secondhand cabinet will generally fetch as much as when it was new.

The store-cases referred to above are made of thin, light deal, and resemble large collecting-boxes. They are corked and papered top and bottom, and are made to close very tightly, so as to exclude as nearly as possible the external air, and with it the enemies to the insects within. Store-cases are made in several sizes, the most convenient, in my opinion, being the two whose measurements are roin. by $8 \mathrm{in}$. and r rin. by r $6 \mathrm{in}$. Two of the former are equal in length to one of the latter, and of nearly the same width. They are both $2 \frac{3}{4}$ in. in depth.

\section{Foes.}

Preserved butterflies have many enemies, which must be carefully guarded against. Cockroaches, clothes-moths, small beetles, and such animals will get at them if the slightest chance is given; but these are large enough to be easily fought against. The worst enemies, mites (dustlice, Fig. 8) and mould, are much more insidious. Mites are so small that, let the cases be closed as tightly as they may, there will probably still be space enough for them to enter, and enter they will unless deterred in some way. Camphor was generally prescribed for this purpose. Camphor, however, will not destroy mites: at the most it will only tend to prevent their appearing; but let them once get into a case, camphor will not drive them away. A more powerful agent-naphthalene-is now used a great deal. As long as this is present the butterflies are almost or quite safe. Just as camphor is, it 
should be placed in the cells of the drawers of the cabinet, and wrapped in paper and pinned in one corner of the store-cases. An already affected specimen, generally discovered by the small heap of dust beneath it, had better be dipped in benzine, and then blown upon till the benzine has evaporated. The mites will be killed, the colours of the butterfly will not be affected, and through the draught caused by blowing the hairs will

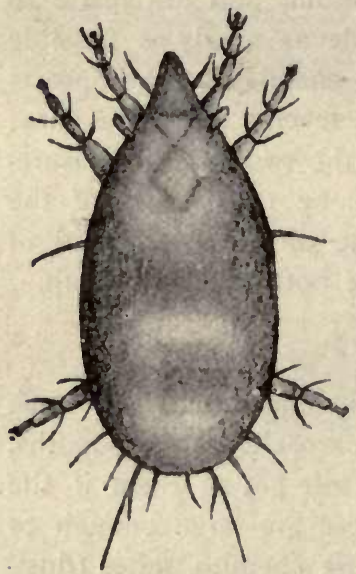

Dorsal View.

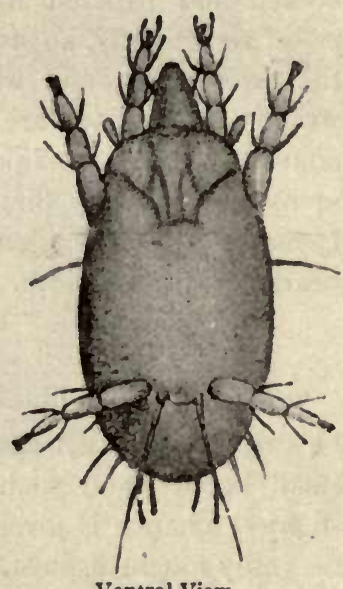

Ventral View.

Fig. 8. The Mite of the Insect Cabinet from Life (magnified 375 diameters).

not be much the worse. Attention may here be directed to an improved form of store-case recently brought out, in which an invisible naphthalene cell in ingeniously provided.

As regards mould, its spores are quite invisible, and are almost always present in the air, waiting for a suitable medium whereon to germinate. Since it is next to impossible to get a case intended to be opened that is 
perfectly air-tight-and if not so, the spores can certainly enter-we must try to keep our cases in such a spot that the spores will not be able to find sufficient moisture to allow them to germinate, and very little moisture is required for such a tiny fungoid growth.

Many prefer to take the bull by the horns and poison their specimens, which will then be perfectly safe against attacks of either mould or mites. The poison used is mercuric chloride $\left(\mathrm{HgCl}_{2}\right)$, commonly called corrosive sublimate, which must be dissolved in spirits of wine (or methylated spirit). A given anount of spirit will only dissolve a certain quantity of the chloride; if too much is put in, some will remain undissolved at the bottom of the bottle. More spirit must then be added, for a moderately weak solution of mercuric chloride will be sufficient for our purpose. Let the butterflies be steeped in this and then dried in a current of air. The colours, which at first disappear, will return as bright as before, and the specimens will be impregnated with the poison, and may be placed with mites or mould without any fear. There are two drawbacks, however, to its usethe hairs and scales are not always as velvety in appearance as before its application, and then, corrosive sublimate is as deadly a poison to men as to mites and mould. Specimens affected with mould should be placed in benzine, and when dried the mould should be rubbed off with a camel-hair brush.

Fortunately, unlike moths, butterflies are seldom affected with grease; if any are, they will probably be the Vanessas. Should a specimen that cannot be destroyed, be so affected, probably the best thing to do is to steep it in benzine collas, and, when the superfluous liquid has been taken off with blotting-paper, to sprinkle over it fuller's-earth, magnesia, or French chalk. After leaving it for some 
hours this must be brushed off with a camel-hair brush, and the insect may look fairly presentable again.

\section{Arrangement in the Cabinet or Cases.}

Now to place the butterflies in the store-cases or cabinet. They must of course be arranged so that the pins on which they are set are upright and in parallel lines. If the collection is so complete that the insects are likely to remain permanently where they are placed, each row had better be separated from the next by a line ruled on the paper. The space should be wide enough to contain the largest butterfly that occurs in the column. There must in most instances be at least four specimens of each species, to shew the upper and under surfaces of both male and female; but in general, room will also have to be found for varieties and aberrations. So that, although there are but about sixty-eight British butterflies, probably a complete collection would contain not less than four or five hundred specimens, even if clrrysalides and preserved larvæ were not added.

Next comes the naming: and here let me advise everyone to employ the scientific names as much as possible, since they are easily learned and are understood by entomologists throughout the world. In the first drawer or case the first column should start with the family name Papilionida. Under that would come the name of the first genus, Papilio. Next would follow as many specimens of the first species of that genus as were needed, and under them the specific name, machaon. We should, perhaps, next put in a purchased specimen of $P$. podalirius, placing its specific name, podalirius, beneath it. Then would follow the name of the second genus, Aporia, followed by specimens of the only species, and then the specific name cratagi, and so on. 
In the following list, the families, genera, and species of British butterflies are set out in order :

\section{Nat. Ord. LEPIDOPTERA.}

\section{Section Rhopalocera (Butterflies).}

Family I. Papilionidæ.-Larva, cylindrical, smooth or slightly hairy; pupa, fastened by the tail, and supported head upwards by a girdle of silk; imago, with six perfect legs adapted for walking. There are eleven species, the colouring of which is almost entirely confined to white, black, and different shades of yellow.

I. Papilio machaon (Linnæus).

2. Aporia cratagi (Linn.).

3. Pieris brassica (Linn.).

4. " rapa (Limn.).

5. " napi (Linn.).

6. " daplidice (Linn.).

7. Euchloë cardamines (Linn.).

8. Leucophasia sinapis (Linn.).

9. Colias hyale (Linn.).

Io. " edusa (Fabricius).

II. Gonopteryx rhamni (Linn.).

1I. Nymphalidæ. - Larva, cylindrical, either spine-bearing or having a forked tail or two horns at the head; pupa, with the head downwards, attached by the tail only; imago, with the anterior pair of legs but partly developed, so that four legs only are adapted for walking. There are thirty species, comprising the Fritillaries, Vanessas, Ringlets, \&c.

12. Argynnis selene (Schiffermüller).

13. " euphrosyne (Linn.).

14. " latona (Linn.).

15. " aglaia (Linn.).

16. " adippe (Linn.).

17. „ paphia (Linn.).

18. Melitea aurinia (Rottemburg).

19. " cinxia (Linn.).

20. " athalia (Rott.).

21. Vanessa C-alhum (Linn.).

22. " polychloros (Linn.).

23. " urtica (Linn.). 
24. Vanessa io (Linn.).

25. ", antiopa (Linn.).

26. ", atalanta (linn.).

27. " cardui (Linn.).

28. Limenitis sibylla (Linn.).

29. Apatura iris (Linn.).

30. Danais erippus (Cramer).

31. Melanargia galatea (Linn.).

32. Erebia epiphron (Knoch).

33. " athiops (Esper).

34. Pararge egeria (Linn.).

35. " megara (Linn.).

36. Satyrus semele (Linn.).

37. Epinephele ianira (Linn.).

38. " tithonus (Linn.).

39. " hyperanthes (Linn.).

40. Canonympha typhon (Rott.).

41. " pamphilus (Linn.).

III. Lycænidx.-Larva, short and stout, woodlouse-shaped; pupa, supported as in Papilionida; imago, with six legs adapted for walking, as in Papilionida. There are eighteen species, comprising the Hairstreaks, Coppers, and Blues.

42. Thecla betula (Linn.).

43. " W-album (Knoch).

44. " pruni(Linn.).

45. " quercus (Linn.).

46. " rubi (Lirn.).

47. Polyommatus dispar (Haworth).

48. " phleas (Linn.).

49. Lycana batica (Linn.).

50. " argiades (Pallas).

51. ", agon (Schiff.).

52. . astrarche (Bergsträsser).

53. , icarus (Rott.).

54. ", bellargus (Rott.).

55. " . corydon (Fabr.).

56. ", argiolus (Linn.).

57. " semiargus (Rott.).

58. ", minima (Fuessly).

59. ,, arion (Linn.). 
IV. Erycinidæ.-Larva, short and stout, woodlouse-shaped, somewhat hairy; pupa, supported as in Papilionida ; imago, male, as in Nymphalida, having four legs only adapted for walking, while the female has six, as in Papilionida. There is but one species, which is brown with yellowish spots.

6o. Nemeobius lucina (Linn.).

V. Hesperiidæ.-Larva, head large and the segments that follow narrower, smooth; pupa, in a slight cocoon among the leaves \&c., of the food-plant; imago, with six legs adapted for walking; antenna, which in two species are slightly hooked, widely separated by the broad head; at rest the hind-wings are nearly horizontal. The seven species bear the common name of Skippers, from their short, abrupt flight.

6r. Syrichthus malve (Linn.).

62. Nisoniades tages (Linn.).

63. Hesperia thaumas (Hufnagel).

64. " lineola (Ochsenheimer).

65. ", actaon (Rott.).

66. ", sylvanus (Esper).

67. ", comma (Linn.).

68. Carterocephalus palamon (Pallas).

\section{Terms used in Describing the Larva, Pupa,} and Imago of a Butterfly.

Before proceeding to take the British butterflies seriatim, it will be necessary briefly to call attention to the chief terms used in describing them in their three stages-larva, pupa, and inago. The larva of Papilio machaon (Fig. 9) may be taken as the type of all butterfly caterpillars. It has always thirteen rings, or segments as they are usually called, the head being reckoned as one, and that the first. $\mathrm{A}$ is the anterior, and $\mathrm{L}$ the anal extremity of the body; $\mathrm{B}, \mathrm{C}$, and $\mathrm{D}$ are the three pairs of true, jointed legs; $\mathrm{E}, \mathrm{F}, \mathrm{G}, \mathrm{H}$, and $\mathrm{K}$, the five pairs of claspers-protuberances of the skin, which do not reappear in the imago. The legs are always on the second, third, and fourth segments, and the 
claspers on the seventh, eighth, ninth, tenth, and thirteenth. The second, fifth, sixth, seventh, eighth, ninth,

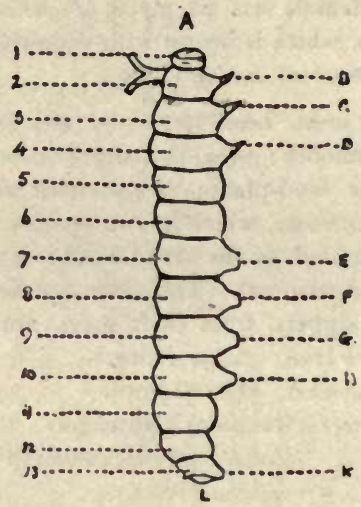

Fig. 9. Diagram of Larva.

tenth, eleventh, and twelfth segments bear each two spiracles (breathing-holes), one on each side.

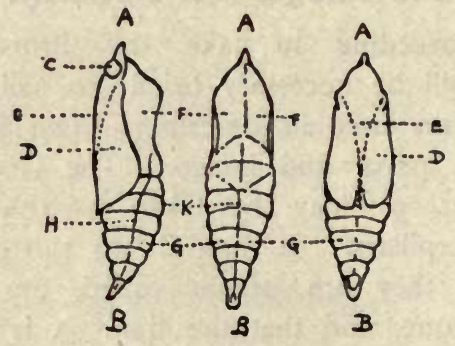

Fig. io. Diagrams of Pupa.

As an example of the chrysalis-stage (Fig. Io) three positions of the chrysalis of Pieris brassica have been chosen; the first giving a lateral, the second a dorsal, 
$c$ is the head, bearing (a) antennæ, $(d)$ palpi, eyes, \&c. ; $e$ is the thorax, and $f$ the abdomen; $b$ is the costal margin of each wing, reaching from the thorax to the tip $(g) ; k$ is the hind-margin, reaching from the tip $(g)$ to the anal angle $(l) ; h$ is the inner margin, reaching from the anal angle $(l)$ to the base of the wing, that is, where it joins the thorax ; $m$ is the tail.

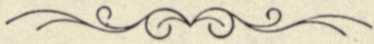


CHAPTER II.

\section{PAPILIONID E.}

\section{Papilio, Linn.}

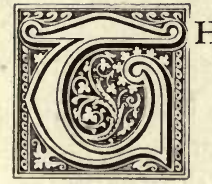

HE queen of British butterflies - the first in rank as well as beauty-belongs to the genus Papilio,* at once the type of its family, the Papilionida, and of the whole tribe of butterflies. The superiority in size combined with the possession of the long swallow-tail on each hind-wing at once separates this from every other British genus. But we may further note that the larva is cylindrical in form and smooth, that the pupa is attached by the tail and kept in an upright position by a band of silk round the upper part of the body (Fig. I5), and that the perfect insect has six legs that it can use in walking, and the knob of the antennæ somewhat elongated. One species only, Papilio machaon, can be reckoned as British, though record has been made of the capture, now many years since, of one or two specimens of $P$. podalirius (Scarce Swallow-tail, Fig. I6)-scarce, that is, as 
far as our islands are concerned, for it is a common butterfly on the Continent.

P. machaon, Linn. (Swallow-tail) (Figs. I 2 to 15 ), though much sought after for the cabinet, is not easily caught, even if the would-be possessor should happen to be in one of the few districts where it may still be found, for it majestically sails along, by the help of its large and powerful wings, with great speed and almost in a straight course, or sometimes soars aloft perfectly safe from the pursuer's net. Why this species should be named after Machaon, a physician, one of the sons of Esculapius, who accompanied the Greek army against Troy, it is hard to see; but the name being once given, it is quite clear why his brother's name, Podalirius, should be bestowed on the second species of the genus.

The larva (Fig. 14), which is often nearly $2 \frac{1}{2}$ in. long, and feeds on various umbelliferous plants, especially the Marsh Hog's Fennel (Peucedanum palustre), the common Fennel (Foniculum vulgare), and the wild Carrot (Daucus Carota), should be looked for from June to August or even September. It is a lively green in colour, and carries behind the head a reddish, two-pronged projection, which it can protrude and retract at pleasure, and which, by emitting a strong-smelling liquid, is supposed to keep off its enemies. The head is marked with black, and there is a velvety black band separating the segments, while another crosses the middle of each segment transversely. Each of these latter bands bears six orange dots, except the first and the last, on which they are fewer or wanting. A black dot or two below the termination of the bands, and another on each of the legs and claspers, except those of the thirteenth segment, complete the marking of the handsomest representative of our butterfly caterpillars. 

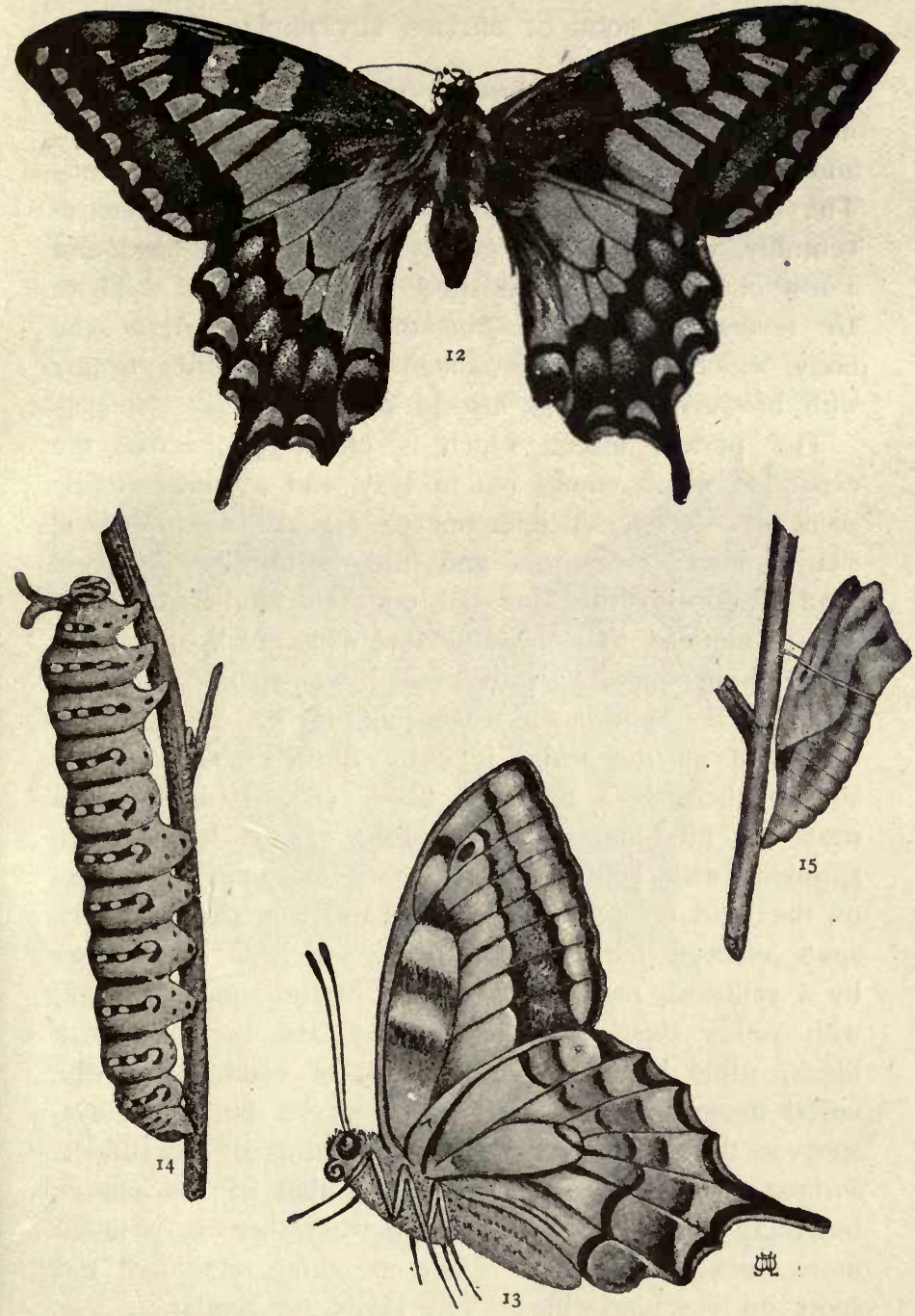

PAPILIO MACHAON. 
In appearance the chrysalis (Fig. 15) is rather aldermanic: it may be found during late autumn, winter, and early spring, attached to dry reeds and similar plants. The colour is usually bright yellowish dorsally, greenish ventrally, with decidedly green wing-cases and head, and a row of ill-defined green spots along each side. There are several protuberances on the anterior part of the body, which is bluntly two-lobed. A variety often occurs with brownish markings instead of green.

The perfect insect, which is often $3 \frac{3}{4}$ in. across the expanded wings, comes out in May, and continues to be seen till August. A reference to Fig. I 2 will show the sharp-pointed fore-wings, and the beautifully scalloped hind-wings with the long tail on their hind-margin. It will be noticed that the abdomen does not lie in a fold of the hind-wings, as with so many butterflies, but the wings are hollowed out to make room for it. The groundcolour of all the wings is dull yellow. On the upper surface there is a band of black crossing both wings near the hind-margin, the middle of the band being sprinkled with yellow dust on the fore-wings and blue on the hind ones. Outside this band is a row of yellow spots, succeeded by a black border, which last is followed by a yellowish margin. The base of the wings is black, with yellow dust, and the nervures are bordered with black, while there is a good deal of black along the costal margin. Each hind-wing bears a large red eyespot at the anal angle. The colouring of the undersurface (Fig. 13) closely resembles that of the upper; but there is much less black, and what there is, is much more thickly powdered. There are three additional red spots on the hind-wings. The sexes are similar.

In Scotland and Ireland the Swallow-tail has, perhaps, never been found; but many of the counties of England 
have at times supplied it, at least singly, though probably most of those that turn up now and again in unexpected places have escaped from captivity. Its chief home now is in the Fens about Cambridge, Huntingdon, and Norfolk, two favourite localities being Ranworth Fen and Wicken Fen, but it is there less plentiful than formerly, and it is to be feared that, as the drainage of the Fens goes on, it will share the fate of the Large Copper, and become extinct as far as our islands are concerned.

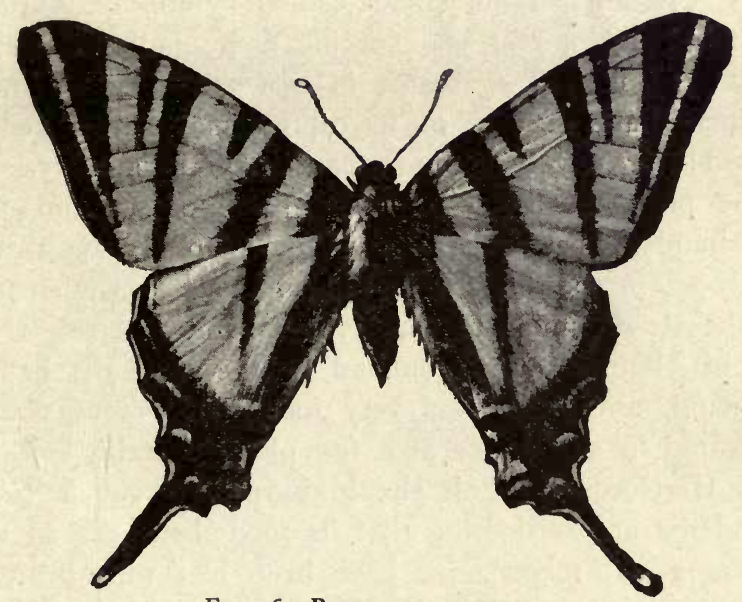

Frg 16. Papilio podalirius.

Though it is, of course, a good thing that the Fens should be drained and cultivated, yet we could not help feeling regret should this remove from our list such an exquisite butterfly as Papilio machaon.

\section{Aporia, Hübner.}

Aporia, the next genus, contains but one British species, cratagi (Fig. 17), and even this has some- 
times been placed in the genus Pieris with the Large White ( $P$. brassica), which, on a cursory glance, it somewhat resembles. But a second glance will shew many points of difference, the most noticeable being the presence of characteristic black spots on the wings of $P$. brassica and their absence from those of $A$. cratagi; and on the other hand, the presence of black nervures on the wings of the latter, and their absence from those of the former.

A. cratægi, Linn. (Black-veined White, or Butterfly of the Hawthorn as the specific name indicates) (Figs. I 7 to 20), is now so scarce in this country, if not quite extinct, that the date of its capture may be marked as a red-letter day in the fortunate naturalist's diary. In some places on the Continent, on the other hand, it is so abundant that its larvæ are looked upon as pests, and justly so, for besides the Hawthorn they affect other trees of the Rose family - the apple, pear, and so on.

This butterfly was confined to the southern half of England, and there was very local, but it occasionally appeared in abundance at a few places, notably in Kent and Hereford. That it should have died out is to be wondered at, considering that its food-plants are so very common. It might once have been met with in Monmouth, Worcester, Gloucester, Somerset, Hants, Berks, Sussex, Huntingdon, Northants, Isle of Wight, \&c.apparently a wide enough range; but, though it was found in all of these districts at least, yet the specimens were as a rule few. The last well-authenticated capture was made on June 9,1888 , at Ramsgate.*

In June the eggs are laid on the Hawthorn (Cratagus Oxyacantha) or else on the Sloe (Prunus spinosa), and

* A note appeared in Science Gossip of January, 1893, mentioning the occurrence of specimens in Cornwall as late as $189 \mathrm{r}$. 
are hatched in from ten days to a fortnight. The larvæ are gregarious - that is, they live together in a silken web
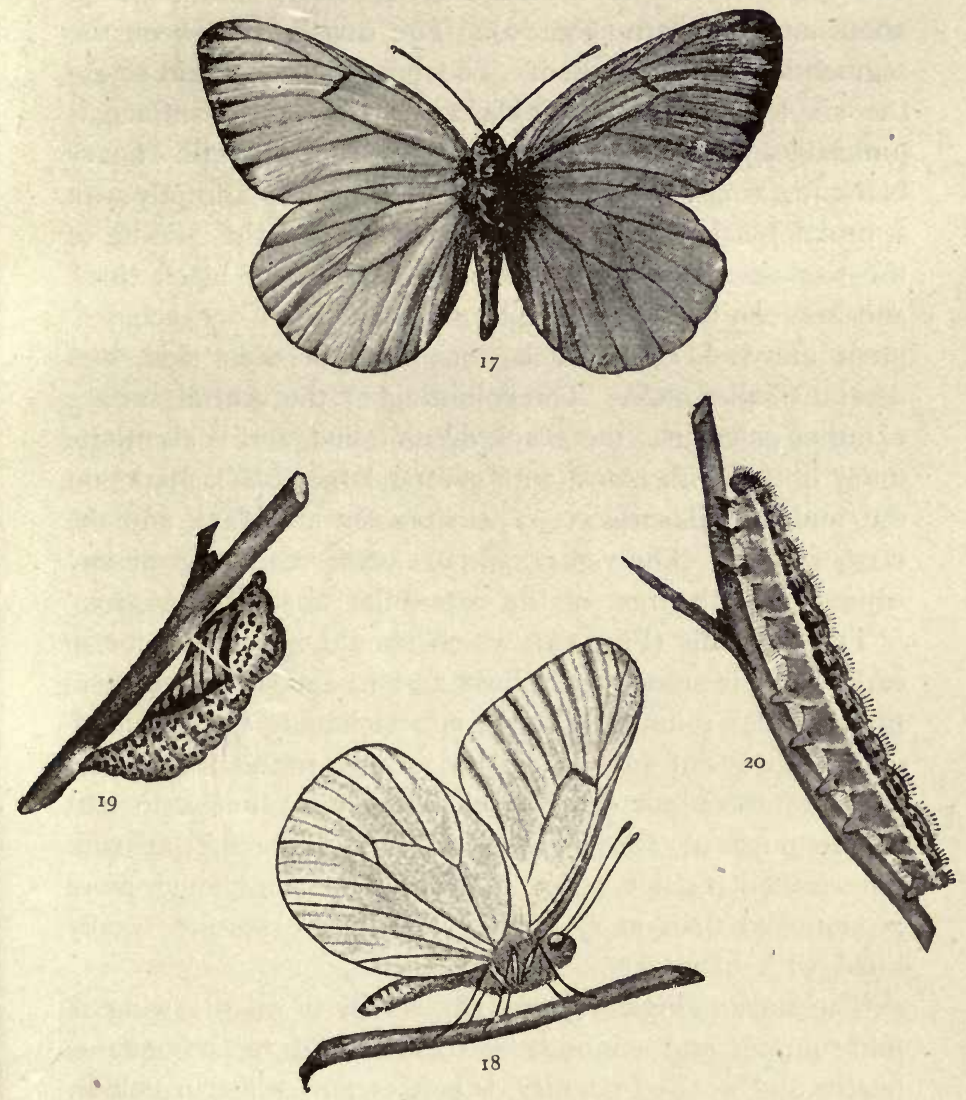

APORIA CRATEGI.

spun by themselves, and only come out of it to feed before and after the heat of the day. They also hibernate during 
the winter in a stoutly-made web of a similar kind. As spring advances, however, they leave the web and separate. They are full-fed about the end of May, and are then about $2 \mathrm{in}$. in length (Fig. 20). The divisions between the segments are well marked. The head is black, and so are the six legs, but not the claspers; the ventral surface is pinkish-grey, and the dorsal reddish-brown with heavy black markings. The dorsal colouring ends abruptly with a broad black band on each side. Along the middle of the back are two fine, somewhat interrupted, black lines; and between these and the broad black lines on each segment are two large black dots, one on each side, and several smaller ones. The colouring of the ventral surface is rather paler near the black division-line, and is elsewhere finely dotted with black, with several larger black marks on the mid-ventral surface. The spiracles are black and the claspers grey. The ventral surface bears a number of fine white hairs; the rest of the caterpillar is slightly downy.

The chrysalis (Fig. 19), which should be sought for in early June, is somewhat robust and has most of the usual prominences rounded off. It is attached to its late foodplant by the tail and by a band of silk round the thorax. The ground-colour is pale yellowish-white, similar to that of the pupa of Pieris brassica. It is marked, too, with numerous black dots; but they are larger and much more pronounced than in brassica. The wing-cases are deeply lined with black.

The imago (Figs. 17 and 18 ), which is on the wing at mid-summer and a month or so afterwards, and frequents heaths and wooded country, is pale creamy-white in colour, and rather thinly covered with scales. All the wings are rounded and fringeless, the boundary being formed instead by a nervure, black like all the rest, as the common name points out. Where each nervure of the 
fore-wings meets the hind-margin is an ill-defined, blackish, triangular mark, which is just hinted at also in the hind-wings. In the female, some of the nervures of the fore-wings are brownish instead of black, and the wings are even more transparent than in the male. The upper and under surfaces are almost identical.

\section{Pieris, Schranck.}

The genus Pieris, named after the Muses (Pierides) who were worshipped on Mount Pierus, contains four British species: brassica, rapa, napi, and daplidice, the first three being particularly common everywhere, while the last is equally scarce. They are on the wing all the season through with the exception of a short period about July between the early and the later broods. The universal admiration which the delicate markings of daplidice call forth is no doubt in a great measure due to its rarity; but, in the eyes of an observer who can admire a beautiful object, even if it is a common one, the other three species are not far behind it in beauty, a beauty due to simplicity. chiefly, for three colours only-a creamy-white together with black and yellow-combine to adorn the insects we are considering. The sexes differ considerably, the variations being remarkably similar in the first three species. The perfect insects have six legs, all adapted for walking, and the knobs of the antennæ rather elongated. The wings have a simple, rounded outline. The somewhat downy caterpillars are almost cylindrical, just tapering a little towards the two extremities.

So common are the larvæ of brassica and rapa in some seasons, that cabbages and other Cruciferce are absolutely riddled by them. Luckily, however, they have enemies, which usually succeed in keeping them 
within bounds. Birds destroy them wholesale, while none too seldom they meet the fate of their food-plant, being cooked and sent to table with it. But they, as well as other larvæ, are subject to the attacks of ichneumon flies, each species, as a rule, having its own particular parasite. These deposit their eggs within the body of their prey, and when hatched the ichneumon grubs feed on the non-vital parts of the caterpillar, till it is on the point of pupating, when they eat their way out and spin a number of small yellow cocoons around their dying host. The appearance of the ichneumon

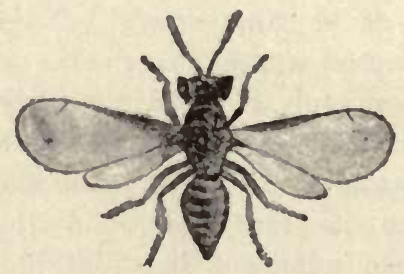

Fig. 21. IChNeUmon FLy OF P. BRassice.

of the Large White will be gathered from Fig. 21 , which is magnified about eight diameters. In all four species the pupæ, which are very much angled, somewhat as in the Vanessida, but not gilt as the latter usually are, bear a strong family likeness. They end anteriorly in a single point: in each there is a greenish or greyish groundcolour, sprinkled with numerous black dots, arranged in a more or less regular manner. All are fastened to a silken pad by tiny hooks at the anal extremity, and further supported by a silken girdle round the anterior part of the body. So supported, they pass the winter not on the food-plant, but under the coping of a wall or in some similar place of shelter. 
If we except the butterflies that hibernate during the winter, the Pierides are the first to appear upon the wing, coming with the primrose, whose pale tints they borrow, and, like it, proclaiming to the world the glad return of spring. The first two species of the genus are those with which a beginner will probably make an early acquaintance, for they are particularly homely creatures, being found plentifully in the gardens, and even streets, of our towns, and moreover falling an easy prey to the hunter in consequence of their slow, uncertain flight.

P. brassicæ, Linn. (Large Garden White, Garden White, Large White, or, as its specific name implies, the Cabbage White) (Figs. 22 to 26), is not only the largest species of the genus but also shares with its smaller relative $(P, r a p a)$ the rather doubtful honour of being one of the commonest of British butterflies.

In May and again in August the yellowish, sculptured eggs are laid in clusters on Cabbages and other Cruciferce, Nasturtiums (properly Tropæolums), \&c. They hatch in ten days or a little more or less, and after four moults are full-fed towards the end of June and beginning of September. The imago of the first brood leaves the chrysalis in July; but the September chrysalides remain unbroken till near the end of the following April, and produce the spring flight of butterflies.

The cylindrical, downy caterpillar (Fig. 26), which is only too well known to many people, often reaches as much as 2 in. in length. The divisions between the segments are not very distinct, and each segment is divided into four sections. There is a medio-dorsal yellow stripe as well as two lateral ones. Above these latter stripes the four sections of each segment are marked with large transverse, somewhat warty blotches, which in the second segment seem to have coalesced. Below 

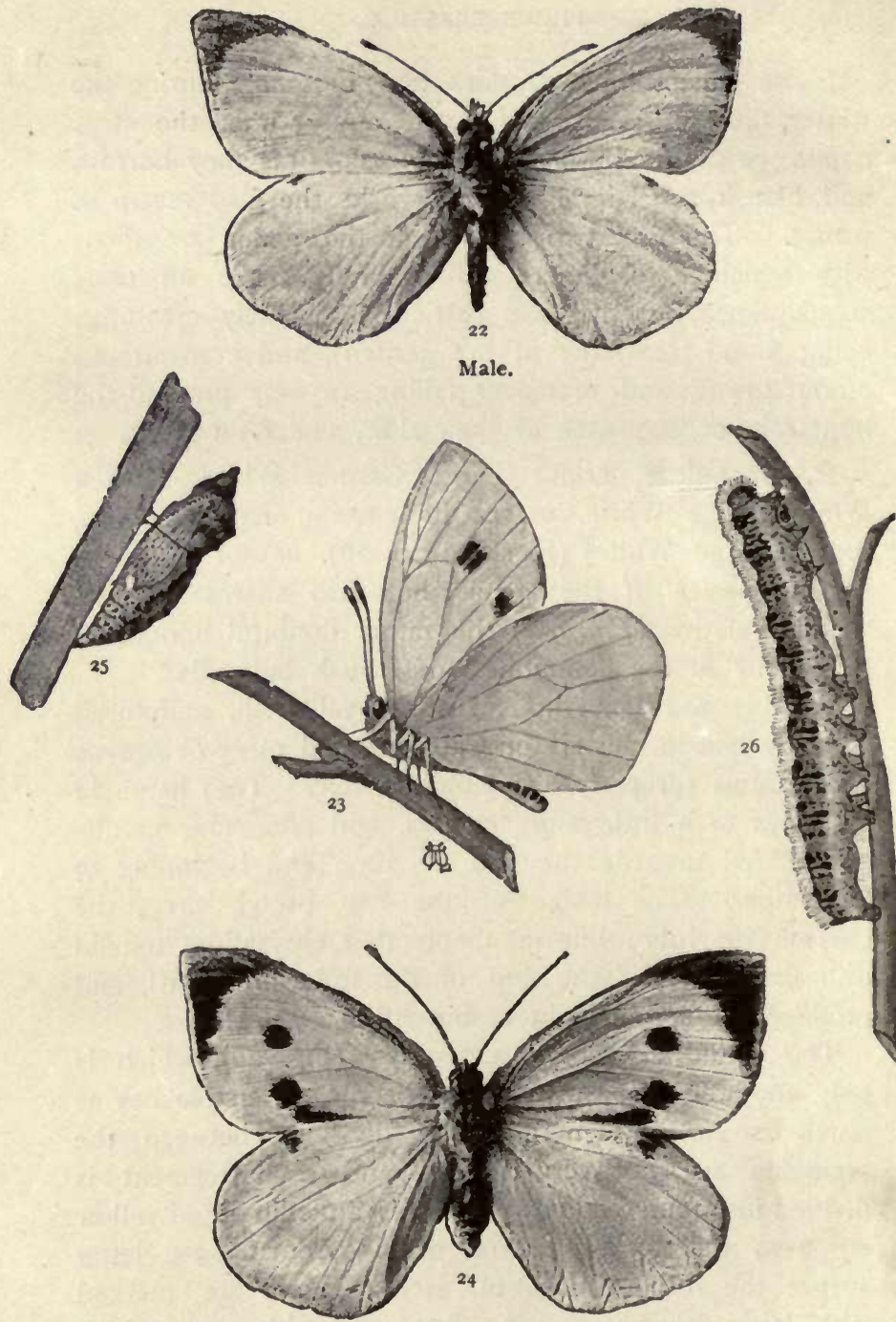

Female.

PIERIS BRASSICE. 
the lateral stripes the black marks are fewer and reduced to dots. On each clasper is a slightly larger black dot, and the head is a good deal marked with the same colour.

The ground-colour of the pupa (Fig. 25) is a greenishwhite, sometimes slightly tinged with bluish-green or red, and always profusely sprinkled with small black dots. It has a medio-dorsal serrated keel and two lateral ones, the projections bearing large black marks and being tipped with yellow. The anterior extremity is pointed; there is a high medio-dorsal point on the thorax, as well as a large projection on each lateral keel near the tip of the wingcases.

The outline of the imago (Fig. 22) is simple, the wings are rounded, the costal margin of the fore-wings is distinctly arched and the tip pointed. The ground-colour is creamy-white. On the upper surface the fore-wings are tipped with a broad black mark, gradually narrowing till it disappears on both the costal and hind margins. On the hind-wings is a small black spot about the middle of the costal margin. The base of all the wings is usually sprinkled with black scales. The female (Fig. 24) has, in addition, a circular spot near the centre of the forewings and another between it and the inner margin, along which is a club-shaped black mark, starting near the second spot and gradually narrowing towards the base of the wing. On the under-surface (Fig. 23) the ground-colour of the fore-wings is creamy, the tip being yellow instead of black, while the two circular spots of the upper surface of the female are present in both sexes. The hind-wings are yellow, powdered with black scales, and having just a trace of the black spot found on the upper surface.

Specimens sometimes occur much more thickly sprinkled than usual with black scales, which give them a very dusky 
appearance. On the other hand, many members of the spring brood have the black tip of the fore-wings much powdered with white scales. This butterfly has been known to cross the straits from France in large numbers.

P. rapæ, Linn. (Small Garden White or Small White) (Figs. 27 to $3 \mathrm{r}$ ), so closely resembles $P$. brassica in colour and markings that, did we not know it in any other than the perfect state, we might be inclined to look upon it simply as a small variety of its larger relative, especially as they are on the wing together, and haunt similar localities. It equals, if not exceeds, $P$. brassica in the damage it does to cabbages and so forth, and like that butterfly is given to migrating at times in large numbers; indeed, we find that on $5^{\text {th }}$ July, 1846, a tremendous flight crossed the straits from France to Dover in so thick a mass as to darken the air as they passed. About the middle of the present century rapa made its appearance in Canada, where it had previously been unknown. Of course, we can hardly suppose that its wings carried it there: it was doubtless unwittingly transported by human agency in the egg or chrysalis state, unless indeed it was knowingly introduced by some experimental entomologist.

Most butterflies only fly in the sunshine, but the Small White is not quite so fastidious in this respect; it occasionally flies, as do its congeners, when the weather is somewhat dull, and even, it is said, after sunset, while it is usually the first on the wing in the morning and the last to retire in the evening.

Several varieties have been noticed, among them one in which the ground-colour of the wings is a bright yellow. The dark markings, too, are subject to much variation in size and intensity, sometimes being almost or quite absent, especially in the spring brood, while in the brood that 
The eggs, which are laid first in April and May, and again in July and August, may be found on Cabbages and other cruciferous plants, as well as on Mignonette, Nasturtiums, \&c. The larvæ of the first brood hatch in just under a fortnight, those of the second in about ten days.

In about three weeks the caterpillars (Fig. 29) are fullgrown, being then about $1 \frac{1}{2}$ in. in length, and green in colour, somewhat darker on the dorsal than on the ventral surface, the two tints being separated by a line of yellow spots in pairs along the spiracular region. There is also a yellow stripe along the middle of the back. The divisions between the segments are not clear, and each segment is divided into half-a-dozen transverse sections. The head and body are covered with numerous tiny warts, mostly black, each of which bears a very short, slender hair.

The chrysalis (Fig. 31), which is light grey usually, though sometimes tinged with red or green, is marked with black dots, which are, however, neither so large nor so numerous as in the case of $P$. brassicre. A few dots larger than the rest are found chiefly on the points of the projections, which are just tipped with pale yellow. There is a medio-dorsal keel as well as a pair of lateral ones, the first having a high prominence on the thorax, and the latter one near the tip of each wing-case. This chrysalis, though slender, has a rather rigid appearance. Very dark specimens are occasionally found.

The imago (Fig. 27), which appears first in April, and is on the wing all the summer through, with the exception of a short period about the end of July, has all the wings rounded, the costal margin arched, and the tip obtusely pointed. The upper surface has at the tip of the forewings a dusky mark much less decided than in P. brassica, a small black spot (absent in the male of $P$. brassica) in 
the centre of the fore-wings, and another in the middle of the costal margin of the hind-wings. The female (Fig. 28) has in addition a second black spot on the fore-wings between the central one and the hind-margin, and a clubshaped mark along that margin, starting from near the second spot and tapering towards the base of the wing. The sexes do not differ on the under-surface (Fig. 30), where the two dots of the female are repeated in both; the tip of the fore-wings is yellow, and the hind-wings are yellow, slightly sprinkled with black scales.

P. napi, Linn. (Green-veined White) (Figs. 32 to 36 ), received its specific name from the Rape, Brassica Napus, which was thought to be its special food-plant, though this does not seem to be the case. A glance at the undersurface of the imago will give a sufficient reason for the bestowal of its common name, except that the veining is often dusky-brown instead of green. It is not easily distinguished from $P$. rapa on the wing, and probably is not quite so common, as it certainly is not so homely.

The eggs, which should be sought for in April and May and again in July and August, are laid chiefly on various cruciferous plants, the commonest being Garlic Mustard (Sisymbrium alliaria), Early Winter Cress (Barbarea pracox), Watercress (Nasturtium officinale), \&c. They are hatched in a little less than a fortnight, and are full-fed during June and September. The imagines resulting from the early brood come out in July and August, while those from the later appear in the following April and May. $P$. napi is therefore on the wing almost continuously from the end of April till August.

The larva (Fig. 34) is of about the same size as that of rapa, and very closely resembles it. The ground-colour, however, is a slightly paler green; there is no dorsal yellow line, and but one lateral yellow spot in each segment. 
The spiracle, which is black in a red patch, is situated in the yellow spot. The subdivisions of the segments, the tiny warts and the short hairs of $P$. rapa are repeated in the caterpillar before us.

The chrysalis (Fig. 36) much resembles that of $P$. rapa. The ground-colour, however, is light green (sometimes
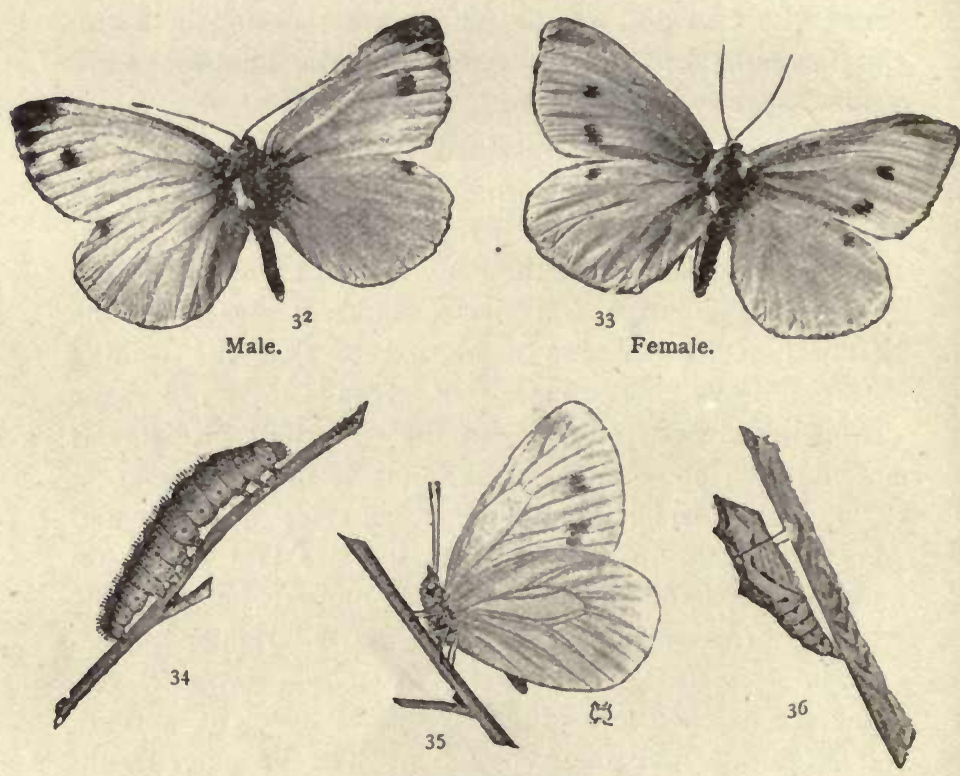

PIERIS NAPI.

pinkish-yellow), some of the points of the keels being yellow. It bears a number of dark brown marks.

The imago (Figs. 32 and 33 ) of both sexes is similar to that of the Small White, except for the addition of the green markings along the nervures on the under-surface (Fig. 35), these markings also appearing more or less, but 
of a dusky hue, on the upper surface, where they spread out forming a small triangle on the outer margin, as in Aporia cratagi. The green colour is produced by a sprinkling of black scales on a yellow ground. When therefore the ground-colour is more than usually white the veinings become a dusky brown instead of green.

$P$. napi varies in distinctness of the green veinings and as much as does the last species in size, as well as in the development of the black markings. Several varieties had once special names, which have now gone out of use.

P. daplidice, Linn. (Bath White or Chequered White) (Figs. 37 to $4 \mathrm{I}$ ), has obtained its second common name from the markings of the under-surface of the hind-wings, which are delicately chequered with green and white. Unfortunately this beautiful butterfly is extremely scarce, all the specimens caught in this country having been taken by chance, there being no spot where one might hunt with a reasonable hope of catching them as there is with some of our scarcer butterflies-the Lulworth Skipper, for instance. No captures have been made except in the south-eastern and southern counties from the Fens to Devonshire. Nor have the individuals been many,' as the following list of captures, recorded in The Entomologist for over twenty years, will shew : 1859, three in Cambs.; I868, one, near Newmarket; I87I, one, near Abbot's Wood, Sussex; 1872, which was somewhat of a "daplidice-year," one near Christchurch, one at Portsdown Hill (Hants), one near Faversham, six or more at Dover, five at Deal, one near Folkestone, one at Tilmanstone (Kent), eight near Beachy Head (Sussex), one at Felixstowe (Suffolk), one at Aldeburgh (Suffolk), two near Newmarket, and one in Surrey; 1876 , one at Folkestone and one near Southend; 1884, two at Dover and one seen near Ashford (Kent); I885, two at' Folkestone. 
There is also an undated record near Kenley Station, Surrey. It does not need a very close scrutiny of the above to raise a suspicion that the English specimens have crossed over of their own free will, or possibly against it, from the Continent, where the species is common. The known migratory habits of its congeners

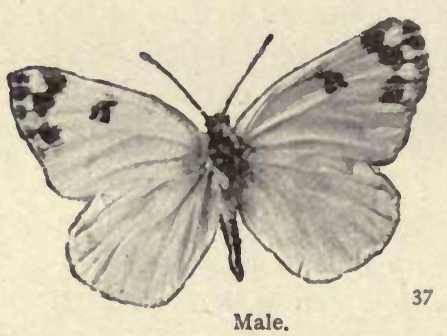

Male.

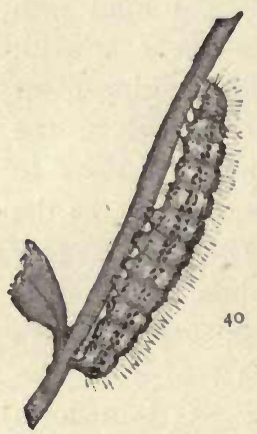

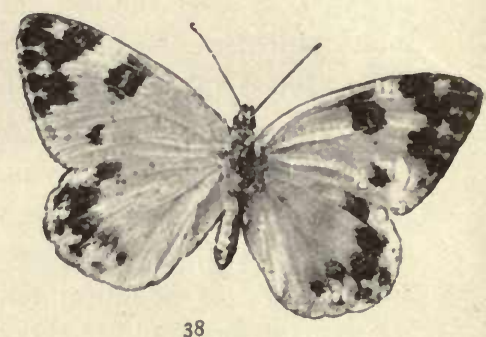

Female.

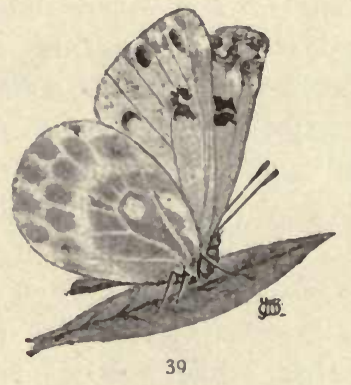

PIERIS DAPLIDICE.

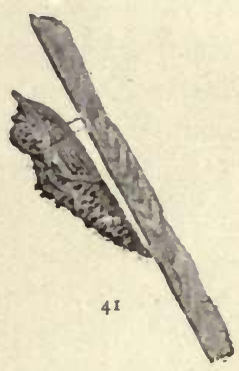

lend plausibility to this theory. Or they may have been accidentally imported in the egg or caterpillar stage from abroad, for most, if not all, of the specimens taken have belonged to the second brood. All the Pierides have weak flight, and this one in particular, so once it is recognised there will be little fear of losing it. It 
might, however, be easily mistaken, and probably sometimes is, for either one of the smaller Whites or the female Orange-Tip, which last it closely resembles in its markings.

The eggs of this much-coveted butterfly will be found if anywhere on one of the two species of Mignonette indigenous to Britain (Reseda lutea and $R$. luteola), and possibly on Flixweed (Sisymbrium Sophia) and other cruciferous plants. They are laid about the beginning of May for the first brood, and again in August or September. The larvæ therefore would be found in May and June, and also in September; the pupæ about July, and also from September till April; while the imago should be on the wing almost any time from April or May till September with the other Whites, the winter being passed of course in the chrysalis state.

The larva (Fig. 40), which is from rin. to $I_{2} \frac{1}{2}$. in length, is of a pale bluish colour, with four yellow stripes, two being dorsal and two lateral, one of the latter along each of the spiracular regions; the ventral surface is somewhat greenish. The caterpillar is covered with black warts and dots of various sizes, from which proceed black hairs; the segments, which are fairly distinct, are subdivided into six sections.

The pupa (Fig. 4I) is greyish, marked with black spots, and having a couple of dark streaks on the wing-cases. It is rather robust and somewhat prominently keeled.

All the wings of the imago (Figs. 37 to 39) are simple, the tip of the fore-wings is rather blunt and the costal margin very slightly concave, the hind-margin of the hind-wings is straight. The ground-colour is white, with a very slight tinge of cream; on the upper surface the fore-wings are tipped with a broad blackish patch containing four white spots, and between this patch and 
the base of the wing is a black spot crossed by a white streak. These markings are to some extent reproduced on the under-surface, but there powdered with yellow, and in addition there is a dark spot near the anal angle, which also shews on the upper surface of the female. The upper surface of the hind-wings in the male (Fig. 37) bears only a few black scales on some of the nervures, but in the female (Fig. $3^{8}$ ) it is chequered with black on the hind-margin, and clouded with the same elsewhere. The chief beauty of the insect, however, is to be found on the under-surface of the hind-wings (Fig. 39), the markings on which form a beautifully chequered pattern of green and white. The green, as in the Greenveined White, is caused by a sprinkling of yellow scales over a black ground. The white of the under-surface of all the wings is also in places powdered with yellow.

\section{Euchloë, Hïbner; Anthocharis, $B d v$.}

Euchloe is the recognised name of the genus to which our next butterfly belongs, though by many Anthocharis* is preferred. Why it has deserved the latter name it is rather hard to say, for what butterfly does not delight in flowers? But perhaps the name refers to the delight we should take in tracing the resemblance that the little Orange-tip bears to a flower that has apparently taken wings to itself with the intention of no longer being fettered down to earth !

E. cardamines, Linn. (Orange-tip, or, according to the specific name, the butterfly of the Cardamine, or Cuckooflower) (Figs. 42 to 47 ), is, for several reasons, one of the favourites of the entomologist. It is not only very common, but, at the same time, very delicately beautiful.

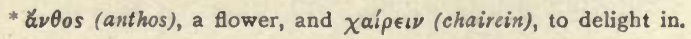


Moreover, it is an early comer, appearing with the Cuckoo-flower, whose name it has borrowed, and finishing its brief existence in early June, ere summer has well commenced. It falls an easy prey to the collector, experienced or inexperienced, for its flight is weak, and the bright orange tip to the wings renders the male a rather conspicuous object by the hedgerow in the spring. The female is not so easily distinguished while on the wing, for the absence of the orange tip gives her much the appearance of a very small White, and her more sober colouring no doubt often proves her safeguard, for more males are usually noticed than females. $E$. cardamines is on the wing but once in the year, and then only for a short time comparatively, so if specimens are wanted they must be sought for, if indeed it is necessary to seek at all, before mid-June. Now and again, however, a few specimens are taken in late summer or autumn; these are representatives of a second brood; that is to say, the chrysalides have produced the perfect insect before the winter instead of after it. All such instances are worth recording in the entomologist's notes. The Orange-tip delights to make its apparently aimless way along the hedgerows, but also may be found in woods and gardens, and almost any other place that butterflies are accustomed to frequent. No particular locality need be given, for it is common everywhere throughout the country.

A habit the Orange-tip has of reposing, when the sun is not shining, on the white flower-heads of the large parsley-like plant Anthriscus sylvestris, is worthy of notice. It is no doubt a case of what is sometimes called "protective resemblance." For when the wings are closed, and only the green-and-white chequering of the undersurface of the hind-wing is exposed, it becomes an 
extremely difficult matter to distinguish the insect from the flower-head on which it rests, for the latter consists of a large number of tiny white flowers, between which show little bits of green, producing a chequering very similar indeed to that on the insect. This is by no means an isolated example: cases of "resemblance" are common not only among the butterflies, but amongst all classes of insects, not to mention divisions of the Animal Kingdom outside the insect group. How many caterpillars owe their safety from numerous enemies to their similarity in colouring to the leaves on which they feed!

The eggs are laid singly about the end of April or beginning of May, on the flower-stalks of some of the following cruciferous plants, and possibly others: Garlic Mustard (Sisymbrium alliaria), London Rocket (Sisymbrium Irio), Hedge Mustard (Sisymbrium officinale), Flixweed (Sisymbrium Sophia), Cuckoo-flower (Cardamine pratensis), Tower Mustard (Turritis glabra), Treacle Mustard (Erysimum cheiranthoides), Charlock (Sinapis arvensis), Winter Cress (Barbarea vulgaris), Penny Cress (Thlaspi arvense), as well as Horseradish and other garden plants. The eggs hatch in nine days, or even less, and the young larvæ feed on the pods and seeds (seldom on the leaves) of the plants enumerated above. They are full-fed on the average about the beginning of July, and after changing into the chrysalis form remain in that stage on the stems of the food-plant till the following April, when the butterfly appears on the wing and remains out till nearly midsummer.

The larva (Fig. 42), which is about $1 \frac{1}{2}$ in. in length, and tapers somewhat toward the anal extremity, is rather dark green dorsally, but yellower on the ventral surface. These two colours are separated by a clear white line, sharply defined below, but gradually fading into the 
green above. Each segment is divided into sections, and the whole surface is covered with tiny warts, each emitting
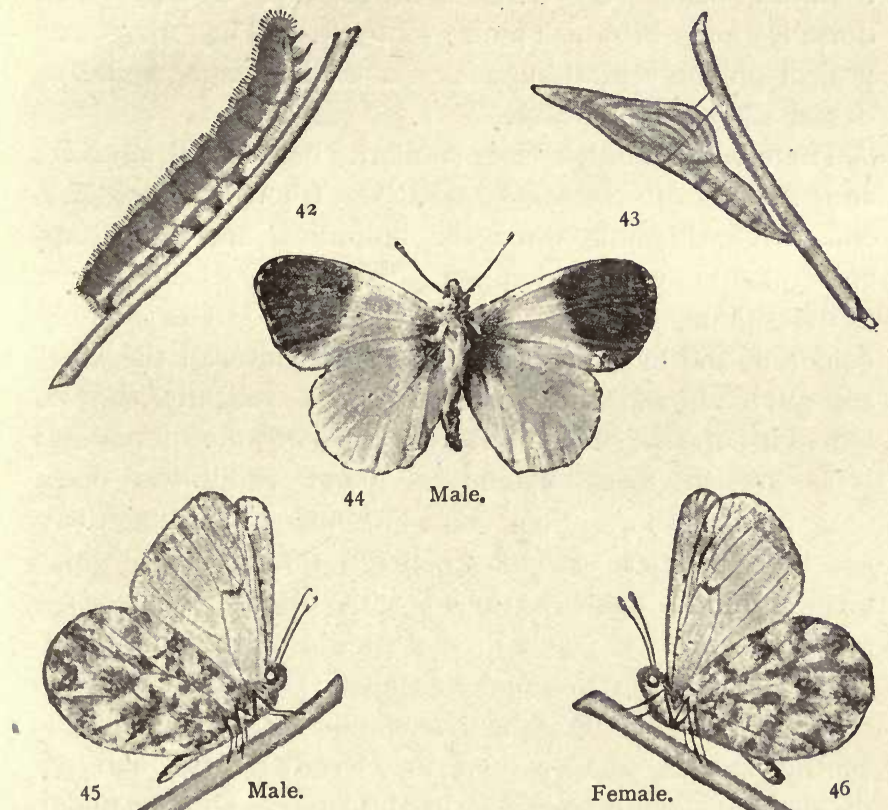

Male.

45

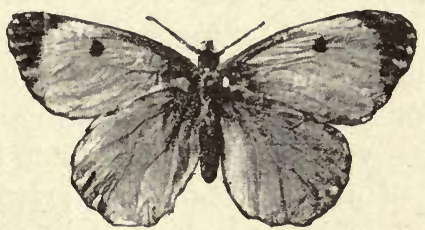

Female.

47

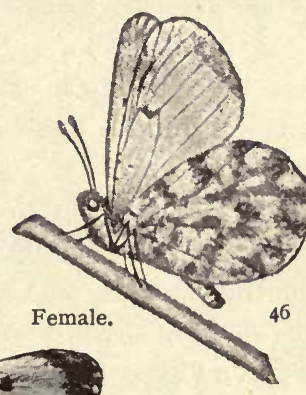

10 )

EUCHLOË CARDAMINES.

a short hair. The warts are black, except on the lateral stripe, where most are white. The head, legs, and claspers are green, the head being sprinkled with black. 
The chrysalis is of the singular shape shown in Fig. 43, somewhat resembling a half-moon, the two extremities being very much pointed. It is dull green dorsally and brownish-pink ventrally. The wing-cases project on the ventral surface as a kind of arch, while the dorsal surface is concave.

There is a somewhat close similarity between $P$. daplidice and the female of $A$. cardamines (though the difference is considerable when the butterflies are compared), consequently when identifying either, especially from a description, great care must be used. The groundcolour of the imago (Figs. 44 to 47 ) is white, all the wings are rounded, and the costal margin is slightly convex. On the upper surface at the tip of the fore-wings is a grevish mark extending about two-thirds down the hind-margin, while on the margin itself there are little patches of white between the nervures, which on the hind-wings are tipped with black. There is a semicircular black patch in the middle of the fore-wings, usually smaller in the male, as also is the patch at the tip; the base of the wings is clouded with black. The . central spot is smaller than in Pieris daplidice, and not divided by a white streak as in the latter. On the undersurface (Figs. 45 and 46 ) the grey tip of the fore-wings is replaced by faint greenish markings on the nervures, and the central spot is repeated. The hind-wings are beautifully chequered with well-defined green markings on a white ground. (In $P$. daplidice the green markings are toned down.) The bright orange patch covering the hind half of the upper surface of the fore-wings, and repeated in part below, distinguishes the sexes. It should be noted that as in $P$. napi the green markings are produced by a mixture of black and yellow scales, easily separable under the microscope. 
There are no very marked varieties of $E$. cardamines, though differences in size occur as well as in the development of the markings, and the ground-colour has been known to be quite yellow.

\section{Leucophasia, Stephens.}

Our attention is next claimed by a little butterfly that belongs to the genus Leucophasia, a name given in consequence of the white appearance of the individuals comprised in it. The genus contains but one British species, whose slender form and small size will doubtless at once distinguish it from every other British butterfly. But should there be the slightest doubt as to its identity, this may be quickly set at rest by reference to the somewhat uncommon length of the nervures arising from the discoidal cell, as shown in Fig. 49.

L. sinapis, Linn. (Wood White), is indeed a very singular little butterfly, quite fairy-like in appearance, with its long, slender body and slight, delicate wings, and possessing no fine markings or bright colours with which to make up in beauty what it lacks in size. But were it ever so fine an insect, its beauty would be lost to the observation of the many, for the Wood White delights to wing its languid way along the silent woodland paths and glades. It is seldom seen to settle, and its aimless flight reminds one of some restless spirit wandering on and on and finding no repose, a fancy aided by the graceful airiness of the little creature.

In consequence of the retired spots which it delights to haunt, the Wood White is none too often seen, though Newman records that it has been taken in most of the counties of England, and abundantly in some places, of which we might instance Lancashire and Westmoreland, and parts of some of the southern counties, Devon, Hants 
Wilts, Surrey, \&c. It does not seem to have crossed the Northern border, and cannot be looked upon as a common insect in Britain or, indeed, in any part of North-Western Europe. L. sinapis is possibly less common in England than formerly, and if we are to judge by captures extending over some twenty years recorded in The Entomologist, its presence is chiefly confined to the southern half of England; South Devon, Worcester, and the New Forest being the localities most often mentioned.

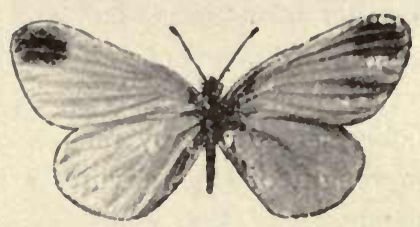

48
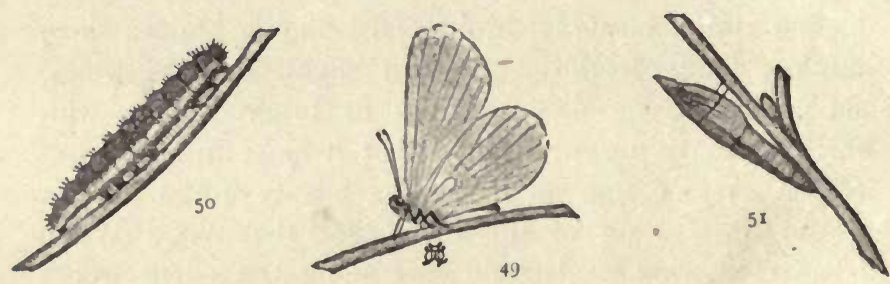

LEUCOPHASIA SINAPIS

The eggs are laid singly about the end of May and again about the beginning of August. The larva is found during June, and again from August till the cold weather begins. The second brood, which passes the winter in the pupa state, produces the spring flight of butterflies in May, while the June caterpillars are in the pupa in July, and produce the second flight of butterflies in August. The larva (Fig. 50), which feeds on the Tufted Vetch 
(Vicia Cracca), Bird's-foot Trefoil (Lotus corniculatus), Tuberous Bitter Vetch (Lathyrus macrorhizus), and Hop Trefoil (Trifolium procumbens), seldom exceeds $\frac{3}{4}$ in. in length. It is nearly cylindrical, just tapering a little towards the two extremities. The segments are divided transversely into six sections, and the surface is covered with short whitish hairs. The ground-colour is green, and the anterior part of the body covered with tiny black dots. The medio-dorsal line is dark green, followed on each side by yellowish-green; then comes a dark green line followed by the spiracular line, which is bright yellow. The ventral surface is green, and so are the legs and claspers.

The pupa (Fig. 5I), which is fastened by the tail and girt, is sharply pointed, especially at the anterior extremity. The ground-colour is a beautiful green, which has a yellowish tinge towards the anal extremity. There is a pink stripe down each side, and the wing-cases are bordered and veined with the same colour.

The ground-colour of the imago (Figs. 48 and 49) is pure white, the only markings being a squarish black spot on the upper surface, at the tip of the fore-wings, and a tinge of black at their base. On the undersurface (Fig 49) there is. in places a sprinkling of black scales, and a tinge of yellow, the latter especially at the tip and base of the fore-wings. In the female the spot at the tip of the fore-wings is often absent, or nearly so.

\section{Colias, Boisduval.}

The genus Colias (containing the Clouded Yellows), is, as far as British species are concerned, a very distinct one. The ground-colour of the imago is white, yellow, or orange, with a dark brown border along the outer margin of all the wings. The fore-wings bear a central 
black spot and the hind-wings an orange one, which underneath is centred with silver. The antennæ are red, a peculiarity which these butterflies share with the genus Gonopteryx, the only species of which-rhamniapproaches the two species of Colias in other respects also. Specimens of the genus are to be found in most parts of the world, many being Arctic. Some of these latter, and, indeed, others of the genus, have a violet or blue tinge to their wings, and so approach the Blues.

The two British species (Figs. $5^{2}$ to $5^{8}$ ) are $C$. hyale and $C$. edusa, both of which in the larval stage feed on various leguminous plants, especially two Clovers (Trifolium repens and $T$. pratense), Lucerne (Medicago sativa), Nonsuch (M. lupulina), \&c. In each case the eggs are laid in the spring, and the caterpillars are to be found in June and July. They enter the chrysalis state about the end of July, and are on the wing from August till they retire in order to hibernate during the winter. Edusa is sometimes on the wing as late as November, but hyale generally retires earlier. They leave their winter quarters, usually much reduced in number, in May, and then the eggs are laid which produce the August flight. The British Edusas occasionally breed in the autumn, and pass the winter in the pupal (or possibly larval) stage. Indeed, it has been thought of late that the winter is oftener passed in the pupal or perhaps larval stage, in which case these butterflies are double-brooded.

Both species, but hyale especially, are very capricious in their appearance. In some seasons edusa, and less frequently hyale, have swarmed in many parts of the south of England, the former being found also in gradually decreasing numbers in the Midland counties, individuals sometimes extending into the very north, and 
even over the Border. Then may follow several years during which very few will be seen, till a fear almost arises that the species may be dying out-a fear to be set at rest by another season of surpassing plenty. Edusa, however, seems to have established itself more firmly of late as a British butterfly. Entomologists have found these capricious appearances a very difficult problem to solve; in fact, no satisfactory solution seems to have been found. Some have suggested that individuals have been blown, or of their own free will have flown, across the sea from the Continent, and these, breeding here, have produced the plentiful autumn flight of butterflies. It has also been suggested that some seasons the eggs or pupæ may lie dormant, and so the butterflies of several seasons may all appear in one. But the plants on which the eggs are laid are scarcely of a nature to preserve them for any length of time. It may be that some years few survive the winter, and leave their hibernacula in the spring, while more do so in others. It was at one time thought that a plentiful season occurred once in seven years; but there have been too many exceptions to allow much faith being put in the supposition, which, however, was not altogether unwarranted.

C. hyale, Linn. (Pale Clouded Yellow or Clouded Sulphur) (Figs. $5^{2}$ and 53), is, like its congener, very swift on the wing, and haunts similar localities, but is by no means so common. Indeed, it must be looked upon generally as a scarce butterfly, though in the southeast of England it occasionally appears in profusion, and singularly enough during the earlier part of the present century these seasons of profusion occurred once every seven years for several times in succession. This came to be looked upon as a law till $\mathrm{r} 849$, since which it has failed. 
When full-fed, the larva, which is seldom seen in England, is $\mathbf{r} \frac{1}{8}$. long, and velvety dark green in colour. In the spiracular region is a whitish-yellow line fading above into the ground-colour. There is a pink spot between each pair of spiracles. The full-fed larva of $C$. hyale and $C$. edusa are very similar, but the former has longer and darker hairs, and a rougher and less rounded appearance, so writes Mr. H. Williams in an interesting paper in The Entomologist, xxvi., p. 7 .

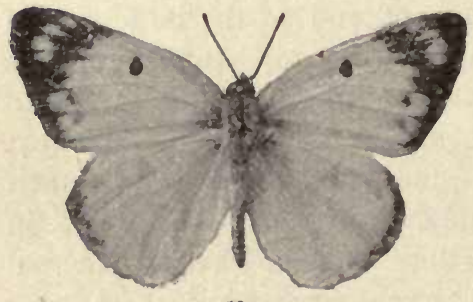

52

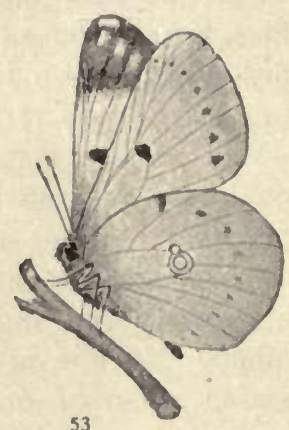

53

COLIAS HYALE.

On the same authority we have it that the pupa of C. hyale is almost identical in shape, colour, and markings with that of $C$. edusa, described below, but, perhaps, is rather more slender and upright. It is suspended by the anal extremity and girt, is green, with a yellowish stripe down each side, and has the wing-cases bordered with the same colour.

The imago of hyale (Figs. 52 and 53) differs from that of edusa in that the ground-colour is bright yellow instead of orange, and that the male, as well as the female, 
has spots in the brown border, which is less clearly defined, and very narrow on the hind-wings and at the anal angle of the fore-wings, besides not being continued along the inner margin of the fore-wings as it is in edusa.

The chief home of hyale in England is in the southeastern maritime counties, especially where chalk prevails; but it is also found occasionally in many other counties. There is a variety of the female in which the groundcolour is white, or nearly so, corresponding to the pale variety of the female of edusa.

C. edusa, Fabr. (Clouded Yellow, or Clouded Saffron) (Figs. 54 to 58 ), one of the most brilliant of our larger butterflies, is usually rather more than 2in. across the wings; these have a somewhat powerful appearance, and well the insect knows how to make use of them, for its flight is very rapid, giving the pursuer little chance of running it down. Indeed, as in the case of so many other butterflies, the would-be possessor does best to watch the creature to a flower, and to take it there. If, in the excitement of the moment a bungling stroke perchance is made, it will be no use paying attention to the edusa that has gone, but be on the lookout for the next one to appear.

Until 1892, this somewhat erratic butterfly had not occurred in profusion since 1877 , in which year it was reported from the Orkneys to the extreme southern point of England; but, after an interval of fifteen years, entomologists were again gladdened by a great "edusa-year," and they are doubtless hoping that in some form or other enough have escaped the winter's hardships and the hunter's net to again delight us with their presence.

The larva (Fig. 58) is cylindrical, like the rest of 

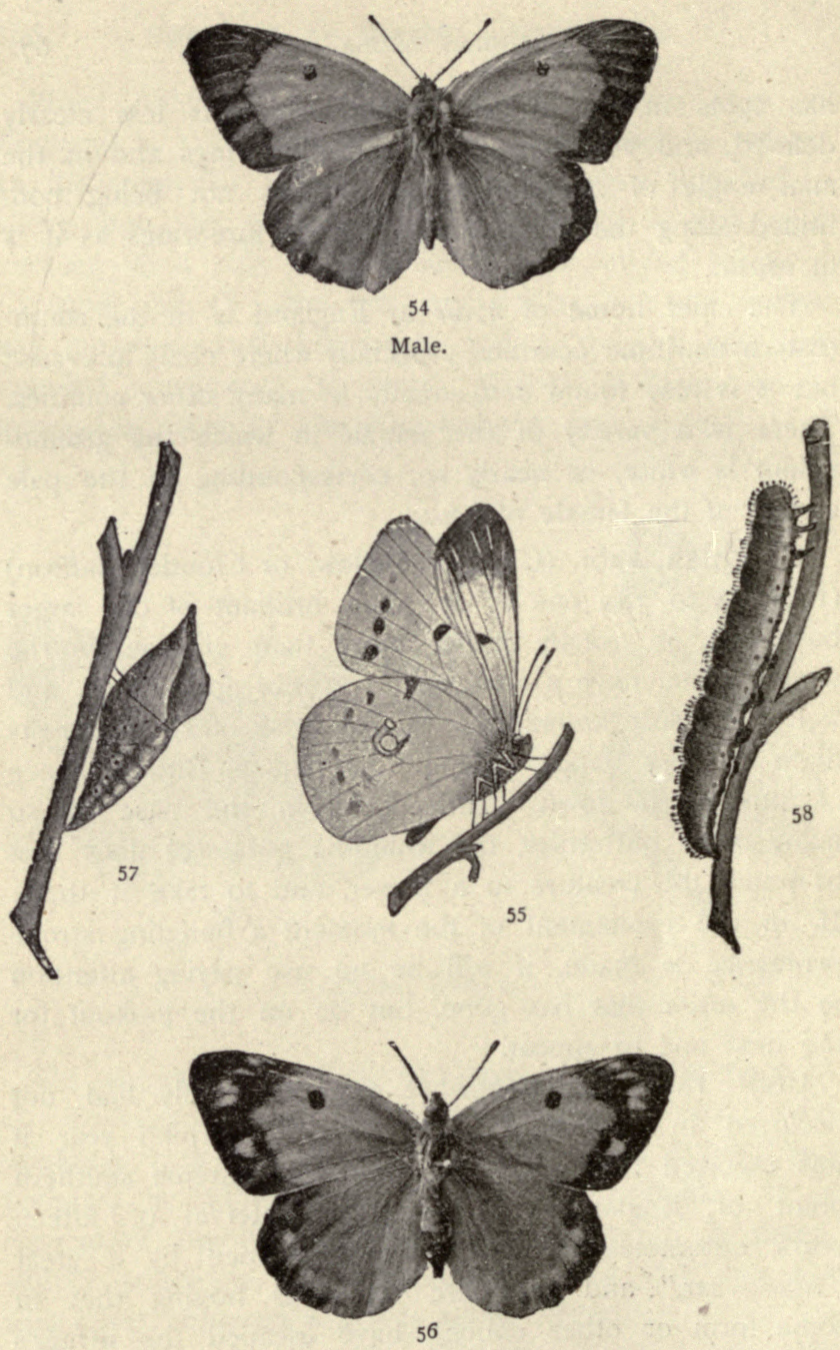

Female.

COLIAS EDUSA. 
its family, but tapers a little towards the anal extremity. The segmental divisions are not very distinct, and each is subdivided into several sections. The groundcolour is bright green, and the surface is covered with minute black warts, from each of which rises a pale hair. The warts are surrounded by whitish circles. There is a rather narrow, white spiracular line, bearing a pinkish patch in each segment, with a black spot below it, and the white spiracle in front.

The chrysalis (Fig. 57), which is suspended by the anal extremity, and girt, is rather stout, something like that of the Brimstone Butterfly, Gonopteryx rhamni. The wing-cases are long, and project ventrally; the anterior extremity ends in a sharp point, and there is a rather pronounced thoracic bump. The colour of the chrysalis is pale green, inclining to yellow in places, especially on the ventral surface. On each side, below the wing-cases, is a dull yellow stripe with three black dots, and a reddish stripe next that ventrally. Each wing-case bears a black dot in the centre, and a row of similar ones near the hind-margin.

The imago (Figs, 54 to 56 ) frequents lanes, meadows, woods, \&c., but especially takes delight in railway-banks and lucerne- or clover-fields. The ground-colour is a deep rich orange, with a broad, dark brown outer border to all the wings. This border bears, in the male (Fig. 54), yellow lines on several of the nervures near the tip of the fore-wings, and in the female (Fig. 56) several ill-defined yellow spots on each of the wings. There is a black central spot on both surfaces of the fore-wings, and a large orange one on the upper surface of the hind-wings, which spot below has a reddish tinge, and contains two silver spots, one very much smaller than the other. The hind-wings and 
the base of the fore-wings are thickly sprinkled with black scales on the upper surface. On the under-surface (Fig. 55) the ground-colour is yellow, with a greenish tinge on the hind-wings and the hind-margin of the forewings, with an orange tinge elsewhere. Besides the markings mentioned thus far, the under-surface has two brown spots on the costal margin of the fore-wings and one on that of the hind-wings, and six dark spots on each wing (smaller and paler on the hind-wings) parallel to the hind-margin. The fringe is pink.

There is a constant variety of the female called helice, Hüb., in which the orange ground-colour is replaced by a yellowish-white. The hind-wings look darker, for the sprinkling of black scales is still present. Specimens sometimes occur intermediate between the variety and the type.

C. edusa has been taken throughout England, and in the south of Scotland; but its home is in the southern, south-eastern, and south-western counties, where it is now usually fairly common, if not abundant. It is somewhat partial to the neighbourhood of London, and becomes less and less frequent as we proceed northwards through the country.

\section{Gonopteryx, Leach.}

When in the early autumn the colours of the ripened fruit and grain make the epithet of golden peculiarly applicable to the time of the year, appears the latest of our English butterflies; and, as if to be in keeping with the golden hues around, it mounts on wings of gold to flutter in the mellow autumn sunshine.

G. rhamni, Linn. (Brimstone Butterfly) (Figs. 59 to 62), is on the wing from August onward, till the cold weather compels it to seek some sheltered nook wherein to winter; but a more than usually warm day will tempt it forth 
again, and it is always one of the earliest butterflies to appear in the spring. As is the case with others that hibernate, the sexes take no notice of each other in the autumn, but pairing takes place and the eggs are laid after the winter's sleep is over. It does not hide its charms in solitary places, but courts the roadside and the garden. It is not easily scared, and, if the net does not enclose it at the first sweep, there is usually a chance for a second; nor is it a particularly active flyer, though its powerful wings appear to be specially adapted for rapid flight.

For a wonder the names of the Brimstone Butterfly are well bestowed. The common name accurately describes the colour of the male insect, the angles of the wings are referred to in the generic name, Gonopteryx (angle-wing), while the specific name rhamni calls attention to the plants on which the larvæ feed: these are the two species of Buckthorn (Rhamnus catharticus and $R$. Frangula), on the twigs of which the eggs are laid singly towards the end of April.

The larva (Fig. 6I) hatches out of the conical yellow egg in about a fortnight, and is full-fed towards the end of June. The general colour is bright green, and the surface is covered with small black points.

The chrysalis (Fig. 62), which is bright green with brownish markings, is to be found on the twigs or under the leaves of the food-plant, hanging by the tail from a pad of silk, which the caterpillar placed beforehand on the twig or leaf. It is further kept in position by a loop of silk stretched across its back and fastened at both ends to whatever support the caterpillar had selected. After twenty days the perfect insect emerges from the chrysalis.

The ground-colour of the upper surface (Fig. 59) of the male Brimstone Butterfly is a bright yellow, like 
that of the crocus or the daffodil; underneath (Fig. 6o) the tint is greener, especially on the hind-wings and the tip of the fore-wings. In the centre of each wing is an orange spot, which is replaced on the under-surface by

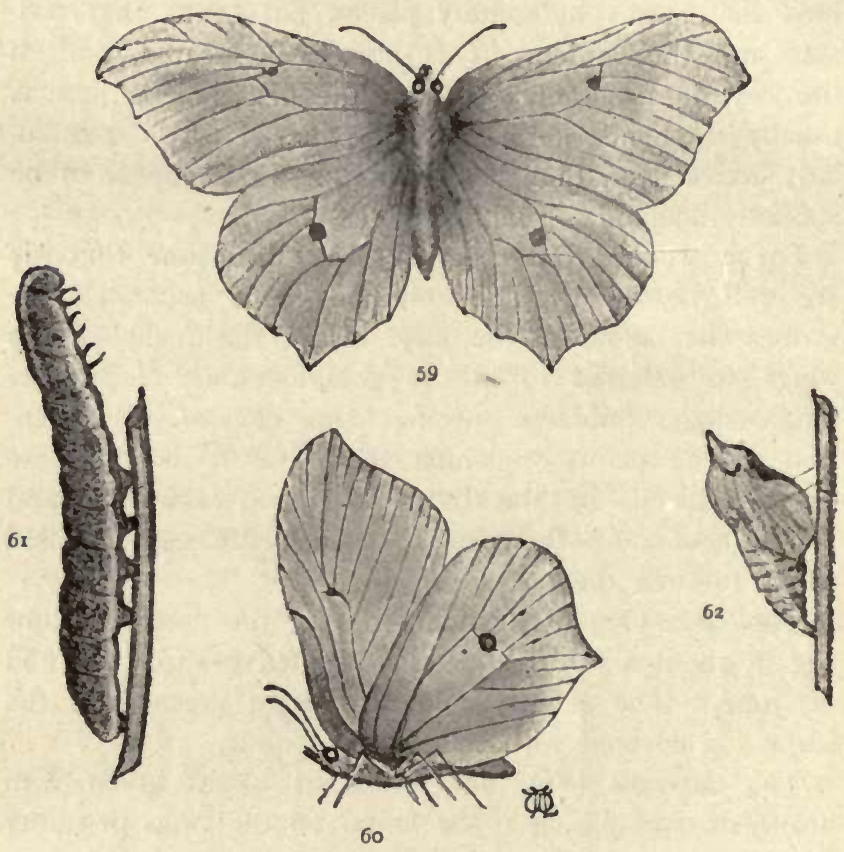

GONOPTERYX RHAMNI

a brown one. There are tiny dark dots at the ends of the nervures, and a row of the same on the undersurface of each wing-three on the fore-wings, six on the hind-wings. Noteworthy features are the stout veins, which, when the wings are closed, give them a very 
powerful look, and the white silky hairs that meet in a ridge over the back of the insect. The antennæ are short, brown in colour, and the tip has a graceful, downward curve. The ground-colour of the female is very pale whitish-green instead of gold, causing it to be often mistaken at a distance for a Large White (Fieris brassica).

G. rhamni is subject to considerable variation in the size of the orange spots-these sometimes, in the south of Europe and other warmer climates, almost covering the upper surface of the fore-wings. This variety has sometimes been described as a separate species under the name of $G$. cleopatra; but as it is said that both forms have been grown from the same batch of eggs, this does not seem to be the case.

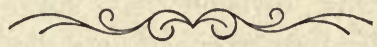




\section{CHAPTER III.}

\section{NYMPHALIDAE.}

\section{The Fritillaries.}

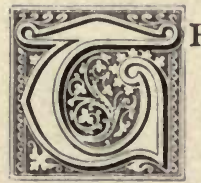

HE Fritillaries form a well-defined group of butterflies, which get their name from a resemblance between the chequered markings of their wings and the somewhat similar markings of the flower of one of our wild lilies, Fritillaria Meleagris, the Fritillary, or Snake'shead. All the Fritillaries have an orange or orange-brown upper surface, chequered with black, but they fall into two divisions at once when reference is made to the under-surface. One division has silver markings, and the other not: the former constitutes the genus Argynnis, the latter the genus Melitcea. The caterpillars are spinous, the pupæ suspended by the tail only, and the perfect insects, like the rest of the Nymphalida, have only four perfect legs adapted for walking. Another little butterfly, Nemeobius lucina, bearing on the upper surface some resemblance to the Fritillaries, goes by the common name of Duke of Burgundy Fritillary; it does not, however, belong to the group, and will be described hereafter. 


\section{Argynnis, Fabr.}

There are six recognised British species in the genus Argynnis: $A$. selene, $A$. euphrosyne, $A$. latona, $A$. aglaia, $A$. adippe, and $A$. paphia. They may be distinguished from the three species of Melitaa by the presence of silver markings (generally spots) on the under-surface, by the convex costal margin of the fore-wings, and usually by their larger size. The antennæ are knobbed and the fore-legs imperfect. In some species the male is known from the female by the presence in the former of black lines on some of the nervures of the upper surface of the fore-wings. The chrysalides are angled, keeled, and suspended by the anal extremity only. The larvæ are cylindrical and usually adorned with long, hairy spines. They are hatched in the summer, but do most of the feeding in the spring, spending the winter on or near the ground at the root of the food-plant or in its neighbourhood. All are grand butterflies-not, indeed, so gorgeous as some that we are accustomed to admire, but with colours warm and rich, beautifully harmonised above, delicately picked out with silver below. Moreover, three are amongst the largest of our butterflies, and all have a strong bird-like flight, seen at its best as they come sailing along some woodland glade in the bright summer sunshine. The food-plant is usually some species of Viola. Besides the six insects enumerated above $A$, dia, Linn. (Weaver's Fritillary), and $A$. niobe, Linn. (Niobe Fritillary), have been claimed as British, but the claim is not usually allowed. In the Northern Hemisphere the genus is a common one extending even to the confines of eternal snow; it is scarce, however, south of the Equator.

A. selene, Schiff. (Small Pearl-bordered Fritillary) (Figs. 63 to 66$)$, is the last and usually the least of its genus 
The term small is, however, rather misleading, as specimens of euphrosyne occur quite as small as, or even smaller than, typical specimens of the one before us. Selene frequents, speaking generally, the same localities and situations as euphrosyne. In England, however, it is not so common as the latter, but in Scotland is more abundant; it appears on the wing about a fortnight or three weeks later.
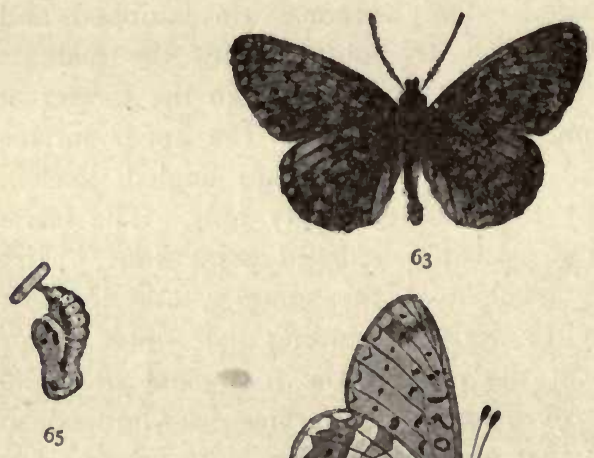

63
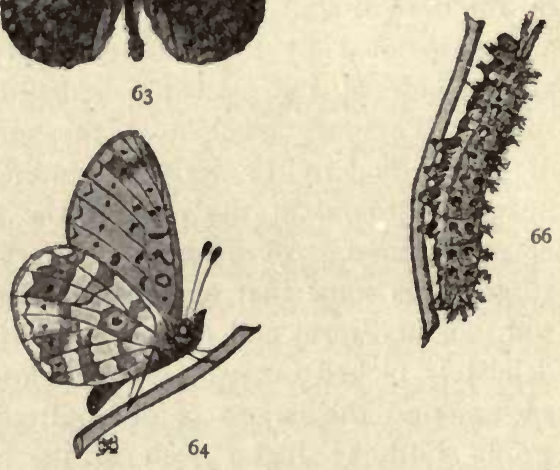

ARGYNNIS SELENE.

The eggs are laid on the Dog Violet (Viola canina) about June. The larvæ appear about July, but soon hibernate at or near the roots of the food-plant, and reappear in the spring, being full-fed in May, in which month the pupæ may be found. The imagines are out in June, possibly at the end of May.

The larvæ (Fig. 66) are about rin. in length, and very closely resemble those of euphrosyne. The ground-colour 
is dark brown, and the spines are yellowish, some of them tipped with black; the claspers are dingy red, and the head and legs black.

The chrysalis (Fig. 65), which is attached to the foodplant, is similar to that of euphrosyne and brownish in colour. The abdomen is abruptly curved, and has two rows of short projections representing the subdorsal spines of the larva.

The imago (Figs. 63 and 64) is similar in shape to euphrosyne, and so closely resembles it on the upper surface that for purposes of identification reference had better be made to the under-surface only (Fig. 64). There the ground-colour of the fore-wings is orange-brown, except at the tip, which is yellow, marked with a rather large patch of dark brown; the rest of the markings resemble those of the upper surface, but are fainter. On the hind-wings there is the row of silver spots along the hind-margin. Within these is a broad dark brown band, interrupted in the centre by a yellow patch. This band contains a row of spots as on the upper surface. Next comes a band of pearly-white spots, interrupted in the centre, then some dark brown, followed by the yellow band of euphrosyne, containing three pearly-white spots; then follow some more dark brown patches, interspersed with several pearly spots. There are thus almost twenty pearly spots (scarcely silver), instead of the nine in euphrosyne. The sexes are similar.

A. euphrosyne, Linn. (Pearl-bordered Fritillary) (Figs. 67 to 70 ), is the commonest of the Fritillaries and one of the earliest to appear upon the wing. It is smaller than latona, and much smaller than paphia, aglaia, or adippe, but in the markings of the upper surface resembles them all very closely. Though in general a wood butterfly, like most of its kind, yet it roams abroad, and may be 
taken in many other situations also. No localities need be given for a butterfly that is usually common throughout this country and in Scotland too.

The eggs are laid in May and June on the Dog Violet (Viola canina) and other plants of the same genus. The young larvæ appear about the end of June. They feed till about the middle of July, and then hibernate till early in the following spring. Towards the end of April they
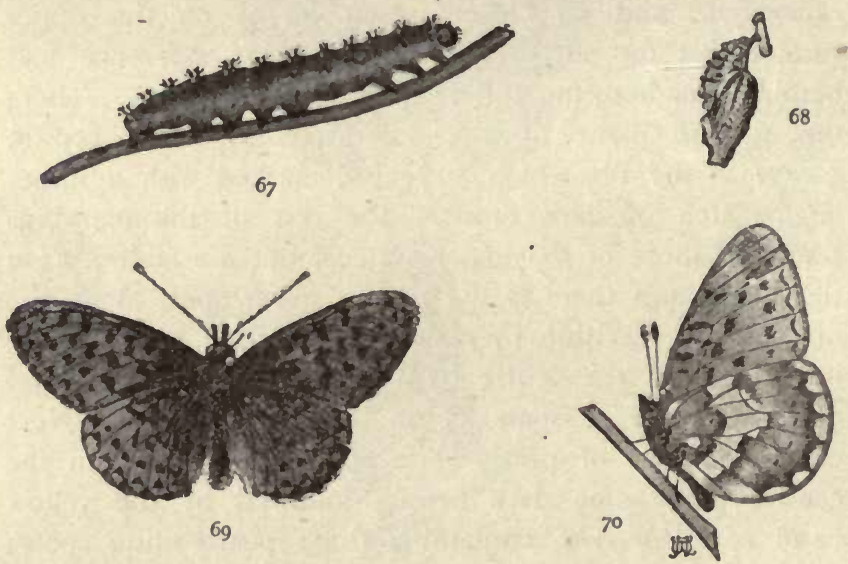

69

ARGYNNIS EUPHROSYNE.

become chrysalides, which are attached to the food-plant, and the perfect insects are on the wing during May and early June.

The larva (Fig. 67), which is about $I_{4} \frac{1}{4}$. in length, is almost black in ground-colour. It is slightly sprinkled with white on the dorsal surface, while along the spiracular region a number of large whitish spots form a broad line. The head, legs, and spiracles are black, and the claspers and ventral surface dull red. The spines on this caterpillar 
are hairy, and arranged as in the other Fritillaries, but they are short. In colour they are black, except the two dorsal rows, which are yellowish at the base and black at the tip.

As with the rest of the Fritillaries, the anal extremity of the chrysalis (Fig. 68) is very much curved. In colour it is greyish-brown; it is stout, and has large wing-cases. The two rows of dorsal spines seen in the larva are repeated on the chrysalis, which is keeled and much angled.

The perfect insect (Figs. 69 and 70) in large specimens expands about $1 \frac{3}{4}$ in. across the wings, but it is often very much smaller. The costal margin of the fore-wings is convex, and so is the hind-margin of all the wings, which are rounded, not scalloped. The upper surface (Fig. 69) of the wings is a rich orange-brown, with black markings arranged as follow: On the hind-margin of all the wings. at the end of the nervures, is a row of triangles; within these, but between the nervures, is a second row; within these again, and between the nervures, is a row of black dots ; still proceeding towards the base of the wings, which is very dark, we find a number of bars joining the nervures in a zigzag manner.. On the under-surface (Fig. 70) the ground-colour is much lighter, and many of the markings are repeated, but more faintly, some of them being brown instead of black. Along the hind-margin of the hind-wings is a row of seven silver spots, fancifully thought to resemble a string of pearls, whence the common name, Pearlbordered Fritillary. Across the middle of the hind-wings is a broad yellow bar, containing in the centre one large silver spot, and there is one more silver spot, triangular in shape, at the base of the wings, making nine silver spots in all on each hind-wing. This number should be noticed, as it forms one of the few marks of distinction between this butterfly and the last, selene. The dark brown markings 
mentioned above as present in selene are represented in euphrosyne by reddish markings not very different from the ground-colour, and therefore not so conspicuous as the same markings are in selene. The sexes are similar.

A. latona, Linn. (Queen of Spain Fritillary) (Figs. $7 \mathbf{I}$ and $\mathbf{7 2}$ ), though one of the rarest of British butterflies, has nevertheless been taken in a considerable number of localities. It is seldom, however, that more than one individual is captured in the same locality at one time. This and the fact that most of the recorded specimens have
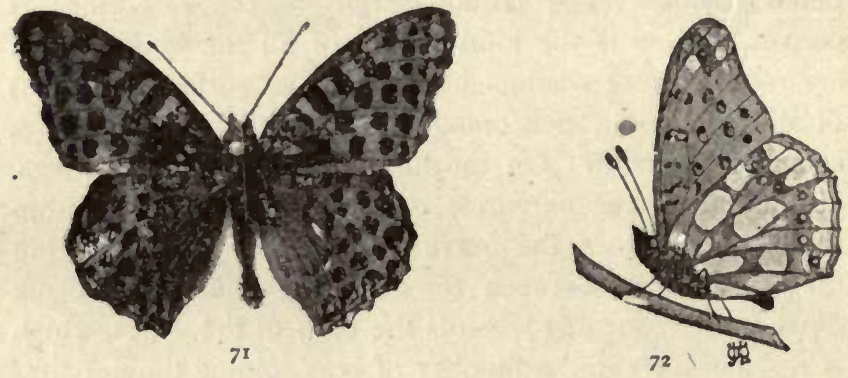

ARGYNNIS LATONA.

come from the south-eastern counties lends plausibility to the theory that they have migrated from the Continent, where they are common. But still it is very probable that latona does breed here sometimes, and we should be pleased to find it making a more settled abode amongst us, for it is a beautiful insect and one that graces the far too meagre list of British butterflies. The greatest number of captures has been made in Kent, Suffolk, Essex, and the Isle of Wight ; but Cambridge, Devon, Dorset, Hants, Norfolk, Surrey, Sussex, and Yorkshire have afforded specimens at least singly. To give some idea of the 
numbers in which latona has been taken in England during the last twenty-one years, the pages of The Entomologist have been consulted for that period, and the following is the result: 1871 , one in Devon; 1872, at least seventy, chiefly in Kent-quite a "latona-year"; 1874 , sixteen, all in Kent, but a little doubt has been thrown upon the captures; 1876 , one in Kent and one in Sussex; 1880 , eighteen near Dover; 1881, one in Essex; 1882, twentyfive near Dover; 1885 , two in Sussex.

The eggs are laid in August, or even September, on the Wild Pansy (Viola tricolor), and also on the Dog Violet ( $V$. canina) and Sweet Violet ( $V$. odorata); Sainfoin (Onobrychis sativa), too, and Borage (Borago officinalis) have been mentioned as food-plants. The caterpillar comes out in about fourteen days, but soon retires to hibernate near the ground under the protection of the herbage round the food-plant. In the latter part of spring it begins feeding again, and enters the pupa state late in June. The imago is out from July to September, or even October, so that it is one of the latest of our butterflies to remain on the wing.

The caterpillar, which is over an inch in length, bears several series of brownish-pink spines. These spines are short, and resemble those of the larva of the last butterfly, A. euphrosyne (Fig. 67). The colour of the caterpillar is dull smoky-brown, with a pair of dorsal and a pair of lateral yellowish-white stripes. The dark spiracular region is bordered above and below with a somewhat lighter tint. The head is yellowish-brown.

In shape, this butterfly (Fig. 7r) resembles rather closely the male of $A$. paphia. The costal margin of the fore-wings is convex, the hind-margin concave. The wings are slightly scalloped, the hind-wings a little more deeply than the fore-wings. The ground-colour of the 
upper surface is a rather deep sienna-brown, with very pale fringe, spotted with black at the ends of the nervures. Starting with the hind-margin of all the wings, we have first two fine black lines, then on the fore-wings a double row of black spots-two spots between each pair of nervures-on the hind-wings three such rows. Within these rows are a few more black spots, and along the costal margin of the fore-wings six black bars. The base of all the wings is dark. On the under-surface (Fig. 72) the fore-wings are lighter, and the markings similar to those on the upper surface, but fainter; there are a few distinct silver spots at the tip in a rather bright brown ground. The hind-wings, where the chief beauty of the insect lies, are yellowish. Near the margin is a row of large silver spots; within these is a row of rich dark brown spots with silver eyes, and within these again a number of silver spots, several being very large. All the spots are clearly defined, and their arrangement will be best made out from the illustration.

A. aglaia, Linn. (Dark Green Fritillary) (Figs. 73 to 76), is possibly not so common as paphia, but rather more so than adippe. It, moreover, does not share to the same extent with the other two their great partiality for woods. It has a liking for ferny hillsides, sand-hills near the sea-shore, and so on. The eggs are laid in August on the Dog Violet (Viola canina) or the Sweet Violet ( $V$. odorata), and are hatched in about fourteen days. The larvæ, after feeding for a time, hibernate near the roots of the food-plants, and reappear in the spring to finish feeding, being full-fed in June. The pupæ may be found in that month and the next, while the imago is out in July and August. It is fairly common throughout England and Wales, occurring in abundance in irregularly scattered localities. It is common in Scotland. 
The caterpillar (Fig. 75), which is nearly $\mathrm{I}_{4} \frac{3}{4} \mathrm{in}$. in length, has, like paphia, six rows of long, hairy spines, black in this species. All the rows are represented on

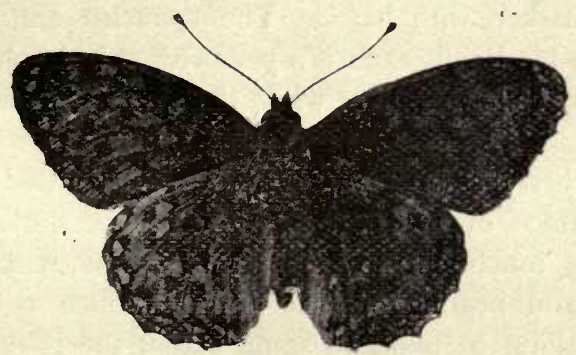

73
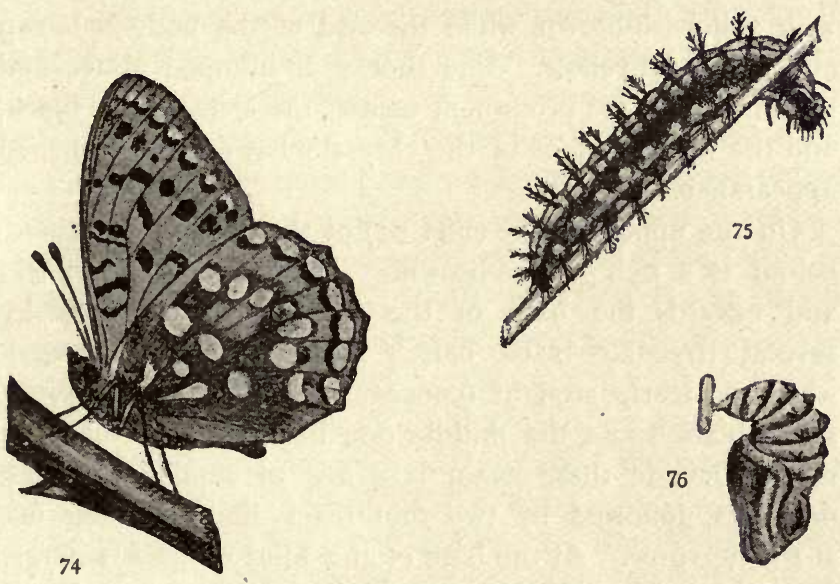

ARGYNNIS AGLAIA.

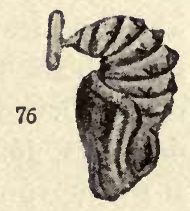

the central segments, but there are fewer spines towards the two extremities, where, too, the caterpillar tapers somewhat. The two spines on the second segment are simple, short, and pointed over the head, which is black 
and shining. The ground-colour of the caterpillar is a dark violet-grey, paler at the divisions between the segments. There is a slender black dorsal line, bordered on each side with dull yellow, and the lateral surfaces are thickly marked with black. The spiracles are black and grey-edged. Below each is a yellowish-red blotch, followed by a thin yellowish line, while the ventral surface is dark brown.

The chrysalis (Fig. 76), which is suspended from the under-surface of a leaf, has, like paphia, the abdominal part very much curved, the segments of it being well defined and bearing on the dorsal surface two rows of points, calling to mind to some extent the rows of spines on the larva. The anterior part is black, marked a little with yellowish-brown, while the rest of the body is brown and brownish-yellow. The thorax is humped above and the wing-cases are prominent below; the spiracles are black, and the whole surface of the chrysalis has a shiny, polished appearance.

On the upper surface (Fig. 73) of the imago the groundcolour is a rich sienna-brown. The nervures are black, and towards the base of the fore-wings are joined by several irregular black bars. Nearer the hind-margin, which is nearly straight (concave in paphia), is a row of seven black spots, the middle one being smaller than the rest. Outside these again is a row of semi-lunar black markings, followed by two thin black lines swelling out at the nervures. At the base of the hind-wings is a large, irregular dark patch (not so much developed in adippe), which patch is followed towards the hind-margin by a row of five spots, the central one being the smallest; the rest of the markings resemble those of the fore-wings. The fringe is pale, but black at the nervures; all the wings are slightly scalloped. On the under-surface (Fig. 74) the 
ground-colour is dull yellow, tinged with red on the basal part of the fore-wings, while the greater part of the hindwings are rich metallic green, tinged with olive-green towards the centre. The markings of the fore-wings resemble those of the upper surface, but are less distinct, and there are a few silver marks, especially an indistinct row of spots near the hind-margin. On the hind-wings there is a row of seven bright silver spots near the hindmargin, backed by green crescents, and in the green portion there are fourteen or fifteen bright silver spots. The dark lines on some of the nervures of the upper surface of the fore-wings of the male - the point of distinction from the female - are not well developed in this species.

A. adippe, Linn. (High Brown Fritillary) (Figs. 77 to 80), like aglaia, which it very closely resembles on the upper surface, is almost as large as the Silver-washed, but scarcely so fine-looking an insect. It flies almost or quite as strongly as the last-mentioned, but has a different appearance on the wing, owing to the darker ground-colour and markings. Besides favouring the flowers of the bramble with its attentions as is customary with most Fritillaries, it has a great liking for the flowers of the thistle, \&c., a taste similar to that of some of its relatives, the Vanessas, and when sunning itself on a head of thistles or a spray of bramble-blossoms, its capture is easy, whereas it is a difficult matter to take it on the wing.

In August the eggs are laid on the Dog Violet (Viola canina), the Sweet Violet ( $V$. odorata), and the Pansy ( $V$. tricolor). In about fourteen days they hatch, and the larvæ, after feeding for a time, retire like those of the rest of the genus to the roots of the food-plants, or to the dead leaves, and so on, that may usually be found lying round them. There they spend the winter, 
appearing again in the spring and being full-fed in June. The pupæ may be found in that month and the next, while the imago is on the wing in July and early August.

Adippe frequents woods and hill-sides in most parts of England and Wales, but is local, though often plentiful where it occurs at all. It does not, as some insects do, become commoner as we proceed southwards, but, as with the preceding butterfly, aglaia, the spots where it is common are scattered here and there through the country-Lincolnshire, Westmoreland, and the New Forest being three amongst others. It is not a Scotch insect.

The larva (Fig. 80) is about the same size as that of aglaia, and, like it, tapers towards the extremities. The spines, too, are similar in number and disposition, but in this case are yellowish-brown. The ground-colour is a rich, dark pinkish-brown, the pink showing especially on the lower surface. On the dorsal surface each segment is adorned with two distinct comma-shaped ( $\bullet$ e) black marks separated by a much lighter streak. The hairy head is a dull lightish brown, and so are the legs and claspers.

The pupa (Fig. 79), which is similar in shape to that of the rest of the genus, has a very dark brownish tinge with golden marks.

The upper surface of the imago (Fig. 77) so closely resembles that of aglaia in ground-colour, markings, shape, and margins, that at first sight no difference can be detected; but a closer examination shows that the dark blotch at the base of the hind-wings of aglaia is replaced in adippe by less compact black markings, though the base of the wings is often very dark too. In the row of five black spots mentioned as occurring on the hind-wings of aglaia, the one nearest the costal margin and the middle one are small or wanting in 
adippe, whereas the central one only is small in aglaia. On the under-surface (Fig. 78 ) the fore-wings very closely resemble those of aglaia; but the markings at the tip

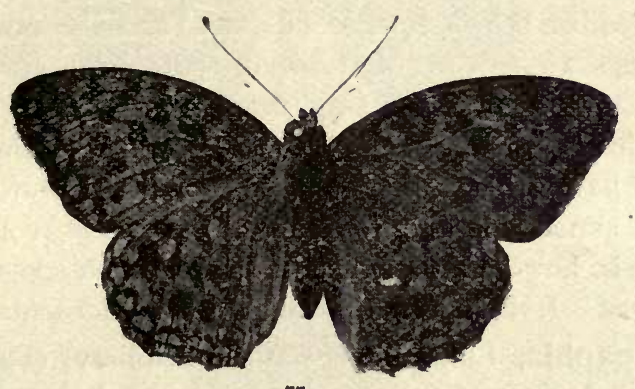

77
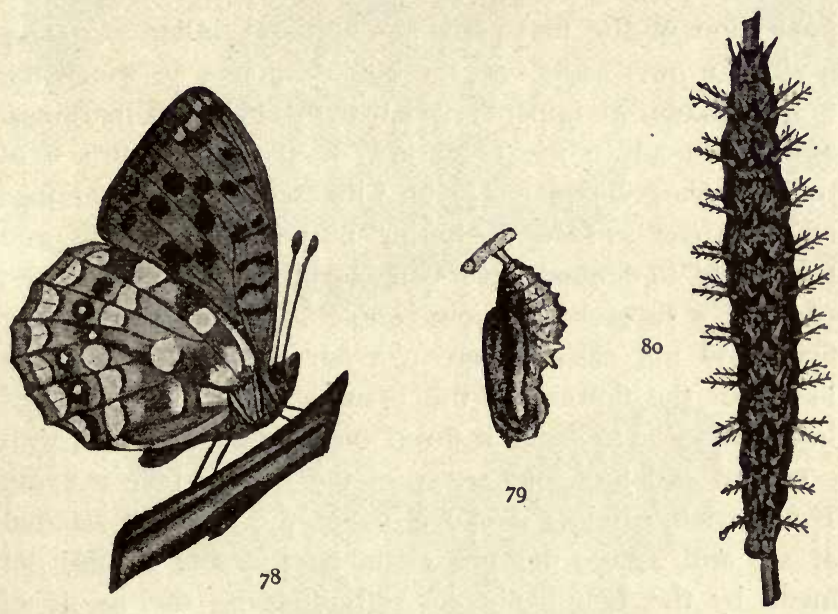

ARGYNNIS ADIPPE.

are tinged with reddish-brown in this, whereas they are tinged with green in the other, and contain in adippe one or two indistinct silver marks, but the marginal row 
of silver spots is absent. The great point of distinction is found on the hind-wings. There is very little green at the base, and this is tinged with reddish-brown. Between the marginal row of seven silver spots (backed with reddish-brown instead of green) and the other silver markings is a row of rust-red spots with silver eyes, which row is entirely absent from aglaia.

As in paphia, the male may be known from the female by its having black lines on some of the nervures of the upper surface of the fore-wings. A variety of adippe, which is, however, rarely seen, has yellowish spots instead of silver. It has been named cleodoxa, Ochsenheimer.

A. paphia, Linn. (Silver-washed Fritillary) (Figs. 8 I to 85 ), will doubtless be allowed by everyone to hold undisputed possession of the first place among the Fritillaries. This position it owes to its size, the bold outline of its wings, the rich sienna-brown upper surface with distinct black markings, and above all to the colouring of the under-surface of the hind-wings-metallic green with traces of the markings of the upper surface, a shifting purplish tinge here and there, and ill-defined silver streaks blending with the rest to form a most harmonious whole. Paphia is a strong flyer, and not easily taken in a fair chase; but it has a liking for the flowers of the bramble, and the collector's best chance is to watch it down on a bush, and then, with a careful and judicious sweep of the net, to take it there. If a hurried, careless stroke is made, the insect, if secured at all, will scarce die unavenged; for a rent in the net made by the bramble-hooks will often be the result of such a stroke. Quiet woodland glades are the haunt of this not uncommon species, and if specimens are wanted, there they must be sought. It seems to be present in most large woods in England and Wales, but is less common in Scotland. 


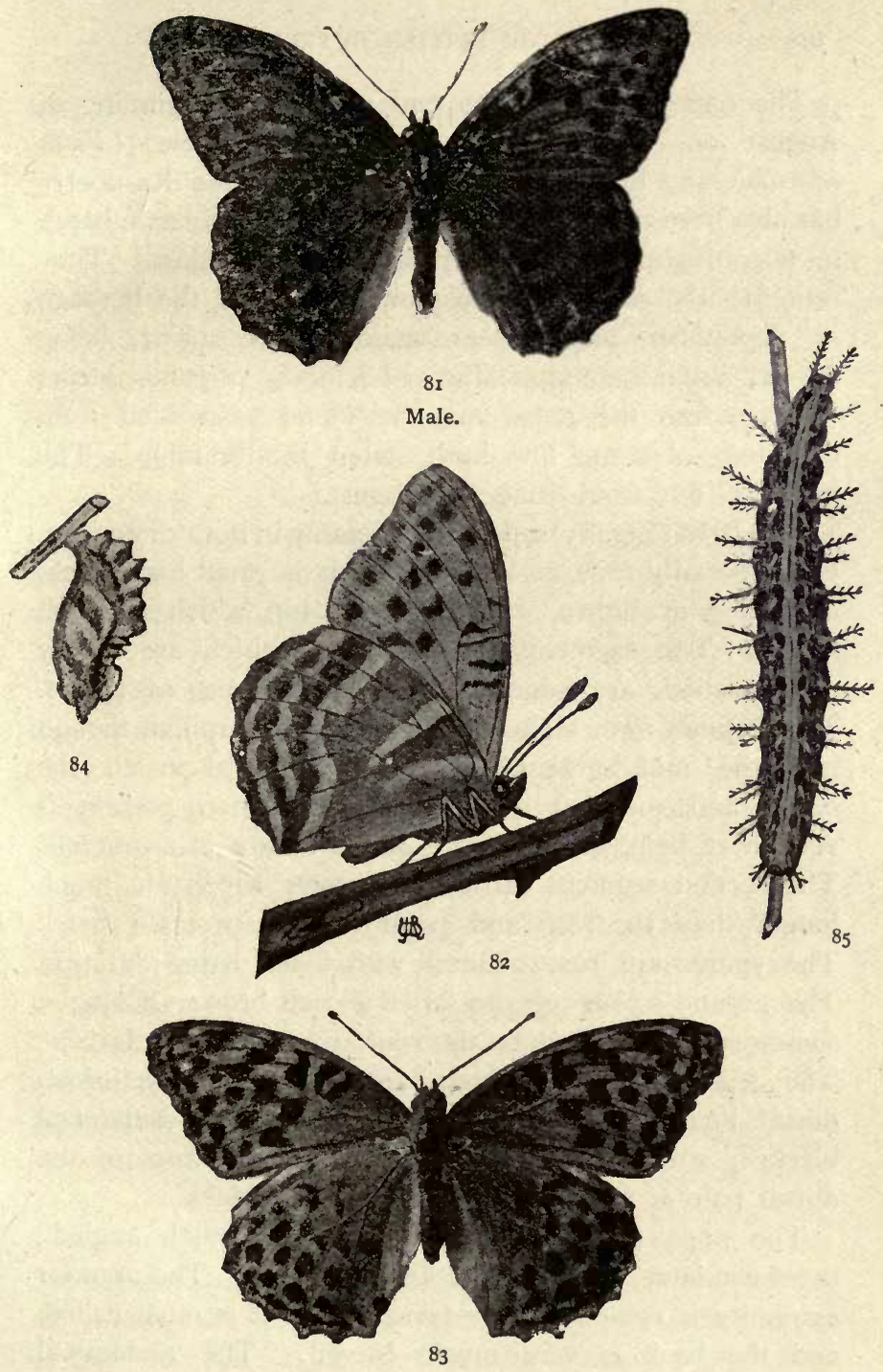

Female. 
The eggs are laid at the end of July or beginning of August on (or near) the Sweet-scented Violet (Viola odorata), and the Dog Violet ( $V$. canina); the Raspberry has also been mentioned as a food-plant. The larvæ hatch in a fortnight, so that they are out in August. They retire to the surface of the ground amongst the herbage in September, and appear again in the spring, being full-fed about the end of May or beginning of June, during which month the pupæ may be found suspended from the stem of some low bush, often the bramble. The imago is out from June till August.

The larva (Fig. 85) tapers considerably in both directions, but especially towards the head; this is small and black, marked with brown, except on the top, which is much lighter. The segments of the body, which are clearly distinguished, are adorned each with a ring of spines. These spines form eight rows along the caterpillar, though only the middle segments are represented in all the eight, and the fourth on each side when present is very short, being in fact more of the nature of a tubercle. The second segment carries two spines, which are much longer than the rest, and point forward over the head. The spines are rust-coloured with black hairs and tips. The ground-colour of the larva is rich brown, having a somewhat smoky tinge on the ventral surface and claspers. The legs are black. There are two distinct yellowish dorsal lines; on each segment are several subdorsal blackish streaks, and a large black spot in front of the dorsal pair of spines. The spiracles are black.

The pupa (Fig. 84) is stout and very much angled; there is a large hump on the keeled thorax. The anterior extremity is two-pointed, or two-eared as it is often called, and the back is very much curved. The abdominal segments and thorax are adorned with tubercles, which 
look as if they had taken the place of some of the spines of the larval stage. The colour is greyish, with darker markings; and, as with several of its near relatives, the surface has in many places a golden lustre.

The costal margin of the fore-wings is much arched, the hind-margin of all the wings is slightly scalloped, and that of the fore-wings rather concave. The fore-wings of the male (Fig. 8r) are much less scalloped than those of the female (Fig. 83). The ground-colour is rich sienna in the male, duller in the female. In the male there is a broad, raised, black line along four of the nervures of the fore-wings. On all the wings the nervures are connected towards the base by black bars, and there are two rows of spots, parallel to the hind-margin, two spots occurring between each pair of nervures; on the hind-wings these spots are almost round, and very regular. Each nervure bears near its extremity a diamond-shaped black spot. On the under-surface (Fig. 82) the forewings are pale yellowish-brown, with black spots, and a few greenish ones at the tip; the hind-wings have been described above.

There is a beautiful variety of the female named valezina, Esper, in which the upper surface is dull brownish-green. In addition to the usual markings, which are made indistinct by the dark ground-colour, there are some. whitish patches near the tip of the fore-wings. The New Forest is a good locality for this variety, but it is sometimes taken in Devon and elsewhere.

\section{Melitæa, Fabr.}

This genus contains three British species-M. aurinia, $M$. cinxia, $M$. athalia - which may be characterised as having on the upper surface the usual orange-brown ground-colour, chequered with black, but as having below 
yellow or white spots, instead of silver ones. The antennæ are knobbed, and the costal margin of the fore-wings is almost straight. The larvæ have short, blunt spines, with black bristles. When hatched, they bind together with silken threads a few leaves of the food-plant, making a kind of tent, under whose protection they live and feed. This they continue to do, taking new and larger dwellings as they grow, till towards the end of summer, when they descend the food-plant and make down among the thicker herbage close to the ground a stronger dwelling-place, in which they pass the winter in companies, appearing again to finish feeding in early spring, when they separate and discard their customary shelter. The pupæ, which are suspended by the anal extremity by means of tiny hooks fastened to a pad of silk usually on the food-plant, are stout, and without any anterior points or keels, either dorsal or lateral, in this respect differing considerably from the genus Argynnis. The sexes are similar. The genus Melitea is well represented in the Northern Hemisphere, except in high latitudes, but does not extend to Africa or South America.

M. aurinia, Rott., M. artemis, Fabr. (Greasy or Marsh Fritillary) (Figs. 86 to 89), obtains its first English name from the shiny, smeared, appearance of both surfaces of the wings, making the insect look very much as if it was affected with grease. The second English name has reference to the localities to which the butterfly is rather partial. It delights to sun itself on the many flowers to be found in damp meadows and marshy spots, where it may easily be caught, for even if it takes wing its flight is weak. The conspicuous larva is often "stung," and falls a victim to the larvæ of a species of Microgaster (an ichneumon-fly), of which twenty or more may be feeding within it at once. 
In early June the eggs are laid on the lower leaves of the Devil's-bit Scabious (Scabiosa succisa) usually, but at times on the Field Scabious (Knautia arvensis), Narrowleaved Plantain (Plantago lanceolata), and Foxglove (Digitalis purpurea), while the larvæ will feed in confinement on the Honeysuckle. The eggs are hatched in about a fortnight, and the larvæ, when about half-grown, retire and hibernate during the winter. They are full-fed about the end of April or beginning of May. After spending about a fortnight as chrysalides, the perfect insects emerge during May, and remain on the wing that month and the next.

This local butterfly is probably to be found in most counties in England and Wales, and in some places in Scotland; but its presence is regulated by the supply of its commonest food-plant, the Devil's-bit Scabious, and the damp spots which it and its food-plant both affect.

The larva (Fig. 86) is about rin. or $1 \frac{1}{4}$ in. long, and has the segments distinct. The colour is black, except on the ventral surface, which is very dark brown, the claspers are lighter, the legs are black, and so is the head, the latter being shiny and covered with black hairs. The body, which is covered with short hairs, is sprinkled with white dots, arranged roughly in three lines: one dorsal and two spiracular, the latter being the clearer. The short, hairy spines are as many as eleven on the middle segments, but less at the two extremities.

The chrysalis (Fig. 87) is short and stout, with a broad head. The back is much curved, and the anal extremity bent forward as in illustration. The colour is white, changing to orange as the time for emergence approaches. The wing-cases, which are slightly produced in front, are marked with black, and there are black markings on the leg and antennæ cases, head, and dorsal 
surface. A few orange dots are also to be found with the black.

On the upper surface of the imago (Fig. 88), starting from the outer margin, we get first the black margin, then a row of yellow semi-lunar spots; next, a broad brownishorange band, divided by the nervures, and each division on the hind-wings containing a black dot; next follows a band of yellow spots, with broad black boundaries; within this, on the fore-wings, are a few spaces, some yellow and some orange, while the rest of the hind-wings is chiefly black. On the under-surface (Fig. 89 ) the markings are very similar, but the black is either very much toned down or reduced to fine lines.

M. cinxia, Linn. (Glanville Fritillary) (Figs. 90 to 9.3), is an extremely local butterfly in England, though plentiful on the Continent. Its stronghold is in the Isle of Wight, and it is seldom taken elsewhere. Other localities that have been mentioned are the New Forest, Kent, Wilts, Cambridgeshire, Lincolnshire, Northants, Yorkshire, and Fife. It usually flies slowly, and may be easily caught.

During May and June the eggs are laid in clusters on the Narrow-leaved Plantain (Plantago lanceolata) and possibly on some other plants, such as those mentioned for $M$. athalia. . The larvæ, while still small, retire in companies for the winter into a retreat of leaves bound together with silk. They reappear in the spring, and are full-fed about the end of April. After about a fortnight, the insect leaves the chrysalis, which is attached to the food-plant or to some object near. The imago is on the wing during May and June.

The larvæ of cinxia and of the other butterflies of the genus Melitaa are very conspicuous, and we may wonder why they do not all fall victims to birds and other enemies to the caterpillar tribe. It is, however, the opinion of 
many that hairy or spiny caterpillars are not usually eaten by birds ; but whether that is so or not, there is doubtless here again an instance of "protective resemblance." The caterpillar (and to a great extent the chrysalis too) resembles very closely indeed the young flower-heads of the plantain, when they begin to appear among the leaves, and on a cursory glance one would be very readily taken for the other. Ichneumons, however, sometimes find out the caterpillars and "sting" them, the fly this time, in some cases at least, being much larger than the one that attacks $M$. aurinia, a single grub only being nourished apparently by one cinxia caterpillar.

The larva (Fig. 90) so closely resembles that of $M$. aurinia that it is difficult to distinguish between them; the head, however, is red instead of black, and the white dots are arranged in a double row encircling the caterpillar at the divisions between the segments.

The pupa (Fig. 9I) is short and stout, with a broad head. It is nearly smooth, and, as with $M$. aurinia, the back is very much curved, and the anal extremity points forwards. The head is almost black, with a few yellowish marks. The colour then shades off posteriorly through a blackish-bronze to yellowish. There are four orange dots on the head in the form of a square, and a few yellowish ones on the wing-cases. Besides these there is a dorsal line of orange dots, one on each segment, as well as two or three lateral lines of a similar colour, the one nearest the dorsal line being distinct, the others not. There are also some black dots on each segment. The rather distinct antennæ-cases are marked with alternate black and white dots.

On the upper surface the imago (Fig. 92) resembles very closely indeed that of the next butterfly, $M$. athalia. In both the ground-colour is rich orange-red, with a kind 
of gridiron-like chequering of black. Perhaps there is rather more black in athalia, but the point of distinction on the upper surface is the presence in cinxia of a line of black dots (absent in athalia) parallel to the hind-margin of the hind-wings. The under-surface (Fig. 93) less closely resembles that of athalia. The fore-wings are orange, with a yellow outer margin and tip. The hind-wings have first a line of yellow spaces along the outer margin, then a line of orange ones with black dots, next a line of yellow ones with black dots, followed by a line of orange spaces enclosing one yellow space, and the base of the wings is yellow, with black dots. There are besides several black dots not yet mentioned, especially on the fore-wings. The markings are distinct, for many of the spaces referred to are defined by clear black lines or nervures. This butterfly varies considerably in different specimens.

M. athalia, Rott. (Heath Fritillary or Pearl-bordered Likeness Fritillary) (Figs. 94 to 97), gets its first common name from the kind of locality the imago frequentsheaths and openings in woods. The second name is not a good one, as it leads to confusion with two species of Argynnis. M. athalia, though very local, is usually abundant where it occurs at all. Its chief home is in the south of England: it is rare in the north. It has been taken abundantly in parts of Cornwall, Devon, Sussex, Kent, and Stafford, and has occurred in Bucks, Essex, Gloucester, Suffolk, and Wiltshire. Like the last butterfly it varies considerably in its markings, and a good series will be required for the cabinet.

The Heath Fritillary is later than the other two species of the genus. The eggs are laid in July, on several plants, among them being the Narrow-leaved Plantain (Plantago lanceolata), the Broad-leaved Plantain ( $P$. major), Wood Sage (Teucrium Scorodonia), Germander 


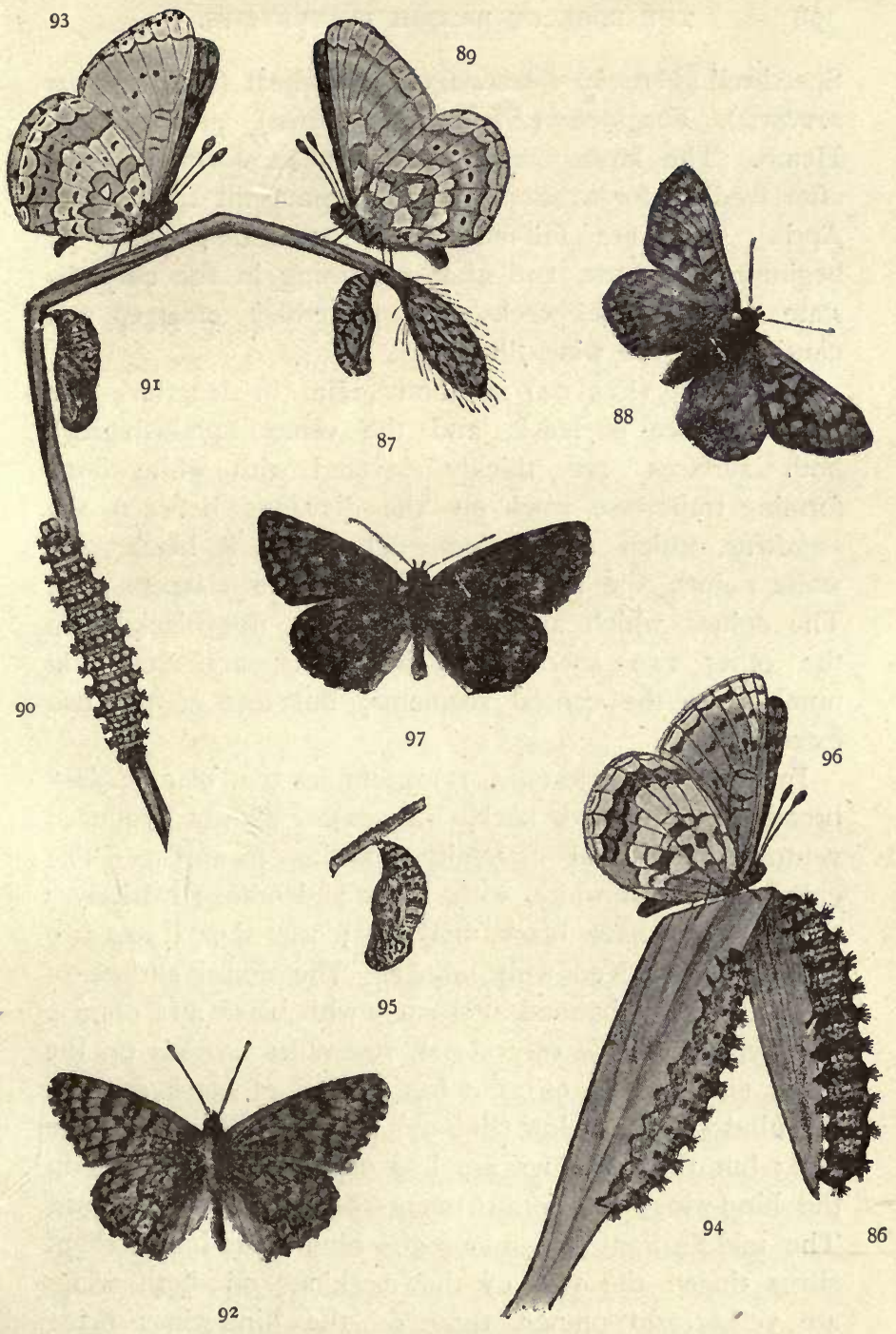

MELITÆA AURINIA (86 To 89), M. CINXIA (90 To 93), AND M. ATHALIA (94 To 97). 
Speedwell (Veronica Chamadrys), Cowwheat (Melampyrum pratense), Foxglove (Digitalis purpurea), and perhaps Heath. The larvæ emerge in about a fortnight, and after feeding for a short time hibernate till the end of April. They are full-fed about the end of May or beginning of June, and after remaining in the chrysalis state about three weeks the butterflies emerge, and continue on the wing till July.

The larva (Fig. 94) is about 1 lin. in length. The dorsal surface is black, and the ventral pinkish-grey; both surfaces are thickly covered with white dots, forming transverse rows on the divisions between the segments, which are distinct. The head is black, with white points, the legs are black, and the claspers grey. The spines, which are yellowish-brown, not black as in the other two species of the genus, are eleven in number on the central segments, but less at the two extremities.

In shape the pupa (Fig. 95) resembles that of auriniabroad head, curved back, wing-cases slightly produced ventrally, and anal extremity pointing forwards. The colour is almost white, with black and orange markings; the leg-cases have black markings; the thorax has two black marks edged with orange. The dorsal surface of the abdomen is banded alternately with black and orange.

A typical athatia very closely resembles aurinia on the upper surface (Fig. 96), but has no row of black dots on the hind-wings. Below (Fig. 97) the resemblance is close also; but the markings are less clearly outlined, and in the hind-wings the compartments contain no black dots. The middle lightest band on the hind-wings has a slight silver tinge; the rest of the markings on both wings are yellow and orange, those on the hind-wings being arranged roughly in bands. 


\section{Vanessa, Ochsenheimer.}

The British Vanessas form a well-defined group of butterflies, possessing, amongst other marked similarities, a great brilliancy and richness of colouring, such as we usually associate with the denizens of countries much more favoured with sunny weather than our own. They are seven in number, and are known as the Comma, $V$. C-album; Large Tortoiseshell, $V$. polychloros; Small Tortoiseshell, $V$. urtica; Peacock, $V$. io ; Camberwell Beauty, Vanessa antiopa; Red Admiral, $V$. atalanta; Painted Lady, $V$. cardui.

For richness, yet simplicity, of colouring the palm must no doubt be given to the Camberwell Beauty, with its wings of deep chocolate edged with cream; the striking contrast of the black, scarlet, and white of the Red Admiral giving that insect a good second place; though perhaps many may prefer to both the more gorgeous Peacock, well-named after the bird whose eye-spots it has so closely simulated. The other four, though coming some distance behind, are nevertheless sufficiently brilliant with their rich, russet ground-colour relieved by markings of black, white, and blue. The outlines of all, except the Painted Lady and the Red Admiral, are indented, and this indentation is carried to the extreme in the case of the Comma, as a reference to Fig. 99 will shew. There is very little difference between the male and female in any of the species of this genus.

The Camberwell Beauty is unfortunately scarce, though it is found occasionally-but, as a rule, singly-throughout England. The Comma and the Large Tortoiseshell are none too often found. The Red Admiral, Peacock, and Small Tortoiseshell, are common enough everywhere, and the other-the Painted Lady-is fairly so. All are strong 
flyers and bold insects, haunting the gardens and even streets of our towns, as well as sylvan glades and flowery hillsides, where butterflies are usually to be found. When intent on sipping the nectar of flowers-or it may be, in the case of antiopa, the juices of over-ripe fruitthey may often be taken with the hand.

The Peacock and indeed all the Vanessas delight to sun themselves upon the heads of thistles and other similar plants, and may there be watched alternately opening and closing their wings, one moment displaying all the colours of the rainbow, and the next, may be, a deep, funereal black. Then is the time with a downward sweep of the net to secure the prize; but, should the attempt fail, one would need the speed of the wind to get another stroke, unless, as is very likely, the insect should wantonly return to the same neighbourhood.

A point worthy of note in connection with the contrast between the brilliant colouring of the upper surface and the sombre tints underneath is the means afforded thereby for the insect's protection. Though, for instance, the Large Tortoiseshell would be readily enough seen when displaying its upper surface on the bark of an elm-tree, let it once close its wings and it would need a practised eye indeed to detect its presence.

The caterpillars vary somewhat in colour and in the arrangement of the dots, or lines, or both, with which they are marked, but they are all alike in being adorned with spines. The caterpillar of the Large Tortoiseshell feeds on the elm-for which reason the perfect insect is sometimes called the Elm Butterfly-and also on the willow, which is the food-plant of the larva of the Camberwell Beauty. That of the Comma feeds on various plants, the hop, red currant, elm, willow, and nettle being amongst them. The Painted Lady larva 
affects thistles and the nettle; while the other three keep almost entirely to the latter. All the caterpillars are somewhat conspicuous, and therefore readily found. They can easily be reared, and imagines in perfect plumage may be thus secured. But should several of the caterpillars be seen with one intent hurriedly moving away from the food-plants, let these be taken, for they are just on the point of turning into chrysalides, and the perfect insect may from them be obtained without the trouble of rearing the caterpillars.

The chrysalides of all the Vanessas are similar in form, being very angular, and adorned with metallic, usually golden, spots, whence the term chrysalis, derived from a Greek word meaning "gold," was bestowed upon them, and has been since extended to the pupæ of all butterflies. The chrysalides of this genus are suspended by their anal extremities, without any covering whatever to protect them from the weather; indeed, such a covering would be quite unnecessary, as the pupal state is passed in the height of summer.

The perfect insects are on the wing during the later months of summer and the early autumn. As the cold weather approaches, they retire to some sheltered spot, and there hibernate during the winter, appearing again towards the end of spring, when the eggs are laid which are to produce the summer's brood. Often one - a Small Tortoiseshell especially-that has taken refuge in the roof of some large building, is roused from its winter's sleep, and flutters about quite out of place, when the room has become unusually warn, may be on the occasion of some Christmas festivity.

On account of their ability to live through the winter, we should look with peculiar favour on the Vanessas and a few other butterflies that hibernate like them, for 
they are the first to tell us of the summer that is coming, and the last to remind us of that which has passed.

V. C-album, Linn. (Comma) (Figs. 98 to I0I), on account of the deep indentations and therefore jagged outline of its wings, might at first sight be easily mistaken for a dilapidated specimen of the Large or Small Tortoiseshell, but it will not be long before their more sought after relative is recognised and, with good luck, captured. $\quad V$. C-album should be looked for in open glades of woods or along country hedgerows, especially where brambles grow, for it has a great partiality for these plants. Powerful flight would hardly be expected as an accompaniment of deeply-indented wings, but such is one of the features of this butterfly, which at times may be seen sailing aloft round the tops of the trees, just as is often the case with other species of its genus.

Though at one time widely distributed over England and Wales and in many places common, $V$. C-album seems now to be gradually becoming scarcer and scarcer. The districts round which it chiefly centres appear to be North Wales and the counties on each side of the English and Welsh borders. Outside these localities collectors, if they find it at all, will do well not to expect to meet with it in numbers.

It is uncertain whether $C$-album is single- or doublebrooded. The winter is passed in the perfect state, and the butterflies reappear about May. They are seen from that date onwards, but the chief flight occurs in September and October. The larvæ, which feed principally on the Hop (Humulus Lupulus), the common Nettle (Urtica dioica), and the Red Currant (Ribes rubrum), may be found in July and August, and perhaps in the spring, while the pupæ occur in September, if not before also. 
The full-grown larva (Fig. Ior), the "silver bug" as it used to be called in Sussex when it was common in the hop-gardens there, is about $\mathbf{I} \frac{1}{2}$ in. in length, and

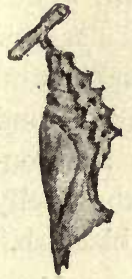

100

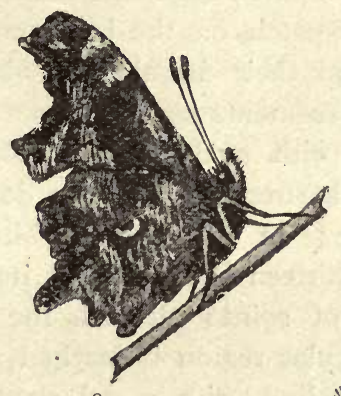

98

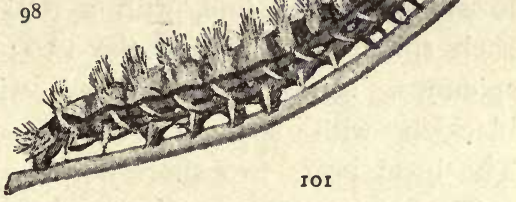

99

VANESSA C-ALBUM.

is armed with short bristle-bearing spines. Ot these there are four on the third and fourth segments, seven on segments five to twelve, and four on the 
thirteenth. The coloration, which is very elaborate, is thus described by J. Hellins : "The ground-colour is black dotted with red, the head black; the second segment has a fine red dorsal line; segments three to six have each a transverse red patch on the back, and the subdivisions lined in red, and their dorsal and subdorsal spines red; then comes on segments seven to eleven a broad dorsal band of white, with a dusky blackish dorsal line, and some short black streaks; here the dorsal and subdorsal spines are white; on twelve this white band ends in a wedge shape; thirteen is black, but its spines are white; the lateral row of spines all red, the subspiracular row pink; the spiracular region is marked with an upper and lower waved red line, with a red slanting streak behind each spiracle connecting the two; the spiracles are conspicuous, being black ringed with white; the belly blaçkish with some red-brown marks; legs blackish." The head bears two short horns.

The pupa (Fig. 100) is about $\frac{3}{4}$ in. long, and has two ears to the head. There is a prominent projection on the thorax, succeeded by a hollow, after which the contour follows a convex arch to the anal extremity. Each side has a subdorsal row of nine small points with reddish tips, and the wing-cases are prominent. The colour is purplish-brown, with a greyish line down the back of the abdomen, which also bears six $\mathrm{V}$-shaped marks. There are six silver spots behind the thorax and a brown stripe along the spiracles; the undersurface of the abdomen bears some dark marks.

The costal margin of the fore-wings of the imago (Fig. 99) is nearly straight, and the hind-margin of all the wings very jagged. The inner margin of the fore-wings has a deep hollow. The colour of the upper surface is brownish-orange, with a broad band of redder brown 
along the hind-margin of the wings. The fore-wings have seven dark brown spots; the hind-wings have three brown spots near the base, and an extra band of brown. The under-surface (Fig. 98), which is mottled with brown, has on each hind-wing a white mark resembling a comma or $\mathrm{C}$, which gives the insect its name. Some specimens have a pale ochreous ground-colour to the under-surface, while others have it dark grey. The former may belong to the suspected early brood.

V. polychloros, Linn. (Large Tortoiseshell, or Elm Butterfly) (Figs. 102 to 105), is one of our larger and finer butterflies, not so gorgeous indeed as some, but sufficiently striking and handsome nevertheless. It is widely but very sparingly distributed through England and Wales, and has been taken in Scotland near Melrose, in Kincardineshire, in Aberdeenshire, and in Argyll, at least. It would be of little use to give localities in England, but it may be noted that the Large Tortoiseshell is considered to occur in the East and in the Midlands more abundantly than elsewhere. It must, however, in any case be looked upon as one of our scarcer butterflies.

The eggs are laid in May on a considerable number of different trees, the Elm (Ulmus) of one species or other being that usually selected. Other food-plants mentioned by various authorities are Sallow, Willow, and more than one species of osier, all belonging to the genus Salix, the Aspen (Populus tremula), the Cherry (Prunus cerasus), and two Pears, the White Beam-tree (Pyrus Aria) and the Common Pear (Pyrus communis). The larvæ are full-fed soon after the middle of June and the imagines are out about mid-July. They retire early in the autumn to hibernate for the winter, and reappear about May or a little earlier. 
The larva (Fig. ro3), which is about 2 in. in length, bears short, branched spines, yellowish-brown in colour,
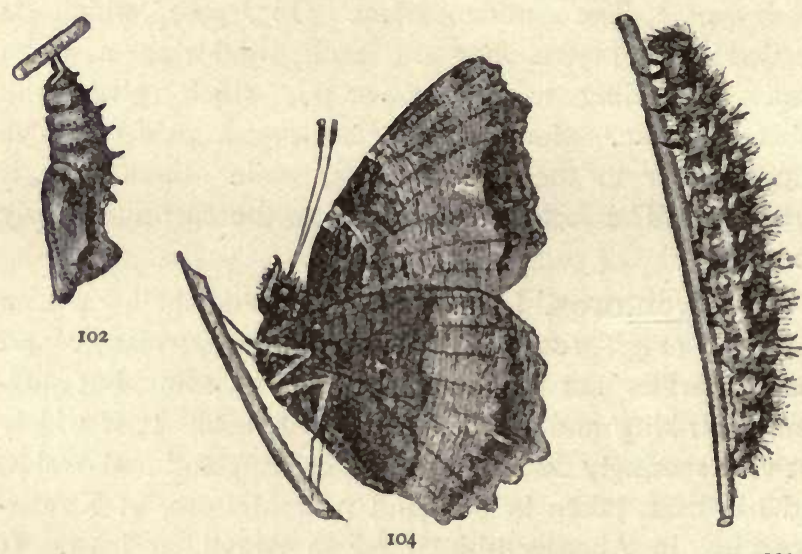

103

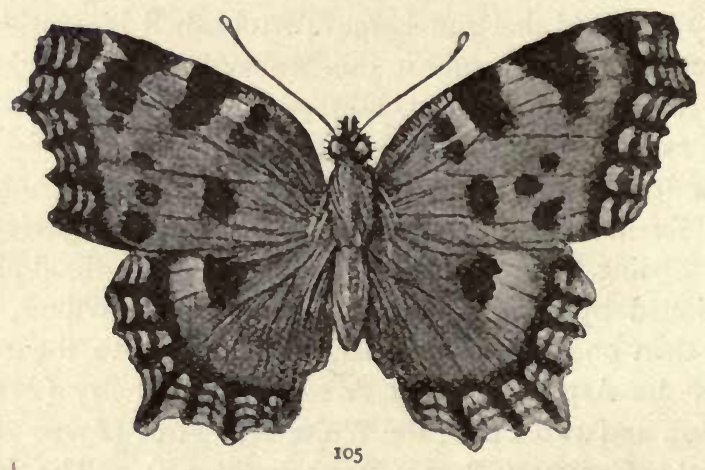

VANESSA POLYCHLOROS.

with black points. The third and fourth segments possess four, the fifth to the twelfth seven, and the thirteenth four. 
The ground-colour is black; the dorsal surface is thickly sprinkled with brown, and down the centre of it is a fine black streak. The sides are very thickly sprinkled with brown and so is the ventral surface, there being on these parts, indeed, more brown than black. The head and legs are black, and the spiracles are of the same colour surrounded with brown; the claspers are brown, with dark markings. The larva is slightly hairy.

The pupa (Fig. I02), about rin. in length, has the head eared and a large projection on the thorax which is laterally keeled. This is followed by a deep hollow bearing six gilt spots, and then by a well-arched abdomen, each side of which has a subdorsal row of sharp darkcoloured points. The colour is a warm brown, lighter on the abdomen, which has on each side a row of tiny black spots on each segment. The anal spike is outlined in black and white.

The imago (Fig. 105) has the costal margin of the fore-wings arched and the hind-margin of all the wings rather deeply indented. This insect much resembles the small one described below; the ground-colour, however, is duller. The spot near the tip of the fore-wings is cream instead of white, and there is an extra black spot near the anal angle of the fore-wings. The marginal blue spots, moreover, are found chiefly on the hindwings. The under-surface (Fig. I04) very closely resembles that of $V$. urtica. This butterfly varies considerably in size.

V. urticæ, Linn. (Small Tortoiseshell) (Figs. Io6 to ro9), unlike its larger relative, is usually common, but, on account of its rich colouring, none the less welcome. Timidity is not one of its attributes, and it may often be seen in flower-gardens, where few blossoms surpass it in beauty. Like $V$. antiopa it has been observed at sugar. 
During May and June the eggs of this insect are laid on the two common Nettles (Urtica dioica and U. urens), and hatch in about a fortnight, the earlier larvæ being full-fed in June. After a week or two as pupæ the imagines appear, and are found on the wing during late summer and early autumn. They then hibernate, reappearing at the return of spring. As a matter of fact, it would be difficult to name a period during the butterflyseason when urtice cannot be found.

The larva (Fig. 109), about $1 \frac{1}{4}$ in. in length, is, like all its relatives, spine-bearing. The spines, which are short and of a brownish colour, with black branches, are disposed four on the third and fourth segments, seven on segments five to twelve, and four on the thirteenth. Black is the ground-colour of the dorsal surface, which is thickly studded with small yellow dots, sometimes forming a medio-dorsal yellow stripe, along the centre of which runs a fine black line. Yellowish-brown is the colour predominating on the rest of the body, which carries two lateral yellow stripes, one above and the other below the spiracles. These are black set in a yellow ring. The head and legs are shining black, and the whole of the larva is downy. Considerable variation is shown in the colouring of individual specimens.

The pupa (Fig. I08) is some $\frac{3}{4}$ in. long, the head is eared, the thorax rises to a sharp-pointed projection and is keeled laterally, the abdomen is arched and bears two subdorsal lines of sharp spines, while the mid-dorsal line has slight indications of the mid-dorsal spines on the larva. The ground-colour is yellowish-brown thickly sprinkled with darker brown. Many specimens are very much gilt, especially on those points which are prominent. It has lately been noticed that the colour 
of the chrysalis varies considerably in accordance with the colour of surrounding objects.

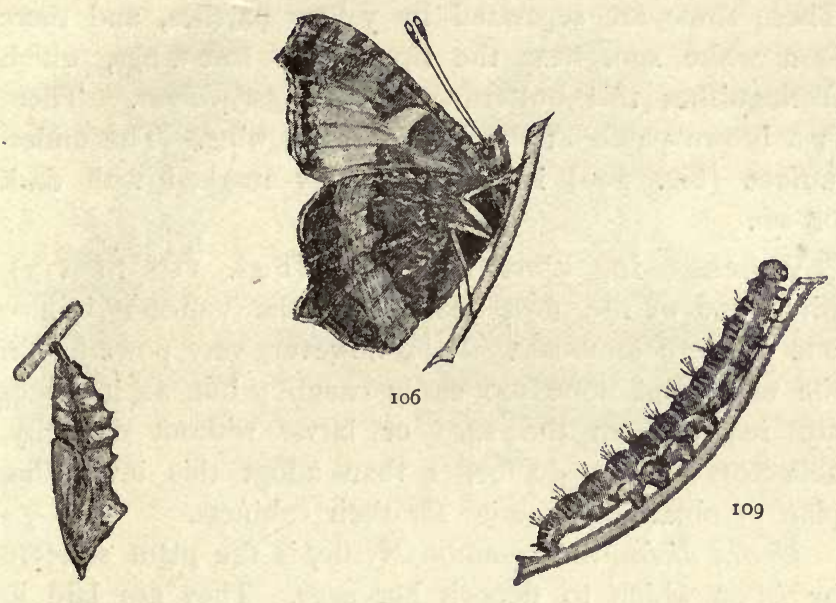

108

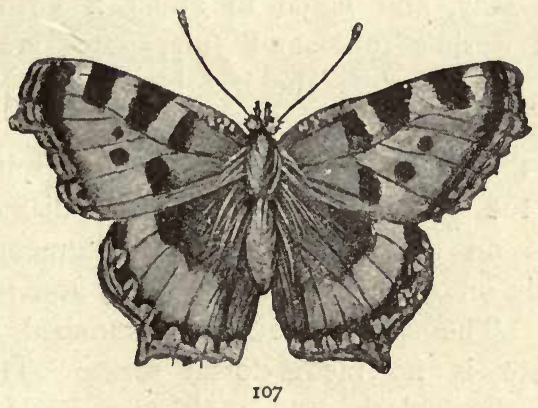

VANESSA URTICA.

$V$. urtica (Figs. 106 and 107) has a nearly straight costal margin to the fore-wings, while the hind-margin of all the wings is scalloped and somewhat angled. The ground- 
colour of the wings is reddish-orange approaching to scarlet, with a blue and black border. The fore-wings contain six black spots, three being along the costal margin. These three are separated by yellow patches, and there is a white spot near the tip of the fore-wings, which distinguishes this butterfly from $V$. polychloros. There is a brown patch at the base of each wing. The undersurface (Fig. I06) is tawny, thickly marked with dark brown.

Vanessa io, Linn. (Peacock) (Figs. I Io to II3), while one of the most beautiful of the Vanessas is also one of the commonest. It is, however, very powerful on the wing, and none too easily caught; but, as imagines are reared from the eggs or larvæ without difficulty, collectors cannot do better than adopt this interesting plan of obtaining a series for their cabinets.

Urtica dioica, the common Nettle, is the plant selected by io on which to deposit her eggs. They are laid in April and May, and hatch in about a fortnight. The larvæ feed during June and July, pupæ are found in July and August, while the imagines appear in August, fly for a time, then hibernate and reappear in the spring.

Though the larva of io (Fig. I 10) has the spines characteristic of the genus they are differently disposed, being situate two on the third and fourth segments, four on the fifth, six on segments six to twelve, and four on the thirteenth. The spines are long, branched, and deep black: there is no medio-dorsal series. The groundcolour is velvety-black, and each segment has several rows of tiny white dots. The head, legs, and anal claspers are black, but the ventral claspers are reddish.

The pupa (Fig. IIf) is over rin. in length; the head carries two long ears; the thorax is laterally keeled, and bears a high dorsal protuberance, while the abdomen 
has on each side a subdorsal line of sharp dark-tipped spines. In colour the pupa varies from brownish to
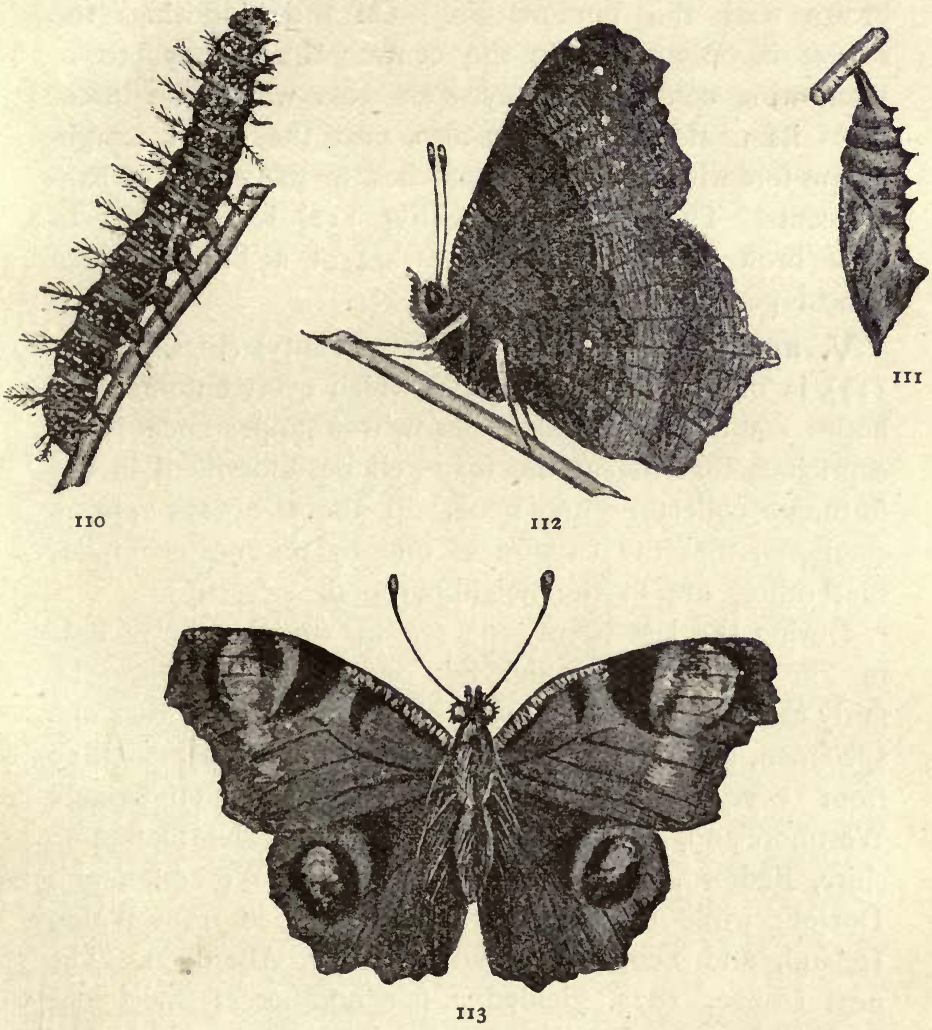

VANESSA IO.

brightish yellow, and is thickly sprinkled with purplish brown" dots, the prominent points being marked with the same colour. 
The costal margin of the fore-wings (Fig. I I 3 ) is slightly convex, and the hind-margin of all the wings angled. The ground-colour of the fore-wings is scarlet, becoming brown near the hind-margin. On the hind-wings the scarlet is only found in the centre; the rest is brown. Each wing contains the eye-spot from which the insect takes its name. There are also near the costal margin of the fore-wings two black patches, in the shape of halfcrescents. The under-surface (Fig. II 2 ) is a mixture of dark browns and black, appearing at a little distance almost perfectly black.

V. antiopa, Linn. (Camberwell Beauty) (Figs. II 4 to II7), is one of those butterflies which every entomologist hopes some day to take, but whose appearance is so capricious that its capture may well be underlined in the fortunate collector's note-book. It almost always appears singly, so that the capture of one by no means inplies that others are in the neighbourhood.

During the last twenty-one seasons (to take the records in The Entomologist only) but one year-1872-can be fairly called an "antiopa-year." In that season at least one specimen, but often a considerable number, was recorded from every county in England, except Cumberland, Westmoreland, Salop, Rutland, Hereford, Northamptonshire, Bedford, Monmouth, Oxon, Wilts, Worcester, and Dorset; while captures are also mentioned from Wales, Ireland, and Scotland as far north as Aberdeen. The next season, 1873, yielded a fair number of specimens from twelve counties, Worcester and Cumberland this time being amongst them. We have but one record in 1874 , seven in 1875, and four in 1876-these twelve occurring in Hants, Gloucester, Surrey, Kent, Essex, Norfolk, Yorks, Northumberland, Dumfries, and Antrim. In 1877 there were six records; in 1878 , three; in 1879 , none; in 1880 , 
twenty-eight, half being in the Home Counties-Essex, Middlesex, Surrey, and Kent-and one in Oxon, which has not yet been mentioned; in $\mathbf{r} 88 \mathrm{I}$, five, three of them being in Middlesex; in 1882 and 1883 , none; in 1884, three, one being in Dorset; in 1885 , three; in 1886 , one; in 1887 , three; in 1888 , eleven; in 1889 , seven; in 1890 , none; and in 1891 and 1892 , one each. From the returns furnished it would seem therefore that the counties most favoured by this exquisite butterfly have been Kent, Surrey, Essex, Hants, Sussex, Middlesex, Yorks, Cambs, and Norfolk; while Westmoreland, Salop, Rutland, Hereford, Northants, Bedford, Monmouth, and Wilts have been entirely unrepresented.

Antiopa may appear at most unlikely times and in most unexpected places. It sometimes feeds at night, for records exist of its having been taken both at sallows and at sugar. One of the characteristics of this butterfly is a decided partiality for ripe fruit, for it has been found feeding on ripe gooseberries, plums, pears, peaches, and greengages at least. Like some others of its kind it has been seen to settle on a freshly-watered road; while a manure-heap and dried cow-droppings as well as trees affected by the larvæ of the Goat-moth (Cossus ligniperda) have lured it to its doom. Antiopa is by no means shy of visiting our streets, and even here its fondness for things sweet has not deserted it, for the attraction of a stray sugar-tub or an empty rum-cask has afforded its pursuer opportunity to approach.

In spring after the winter's sleep is over the eggs of this butterfly are laid on the White Willow (Salix alba), and occasionally on the Birch (Betula alba) and Nettle (Urtica dioica). The larvæ are found in June and July, the pupæ in July, and the imagines from August.

The larva (Fig. I 15) is about $1 \frac{3}{4} i n$. in length and has 
long branched black spines, four on the third and fourth segments, six on segments five and six, seven on
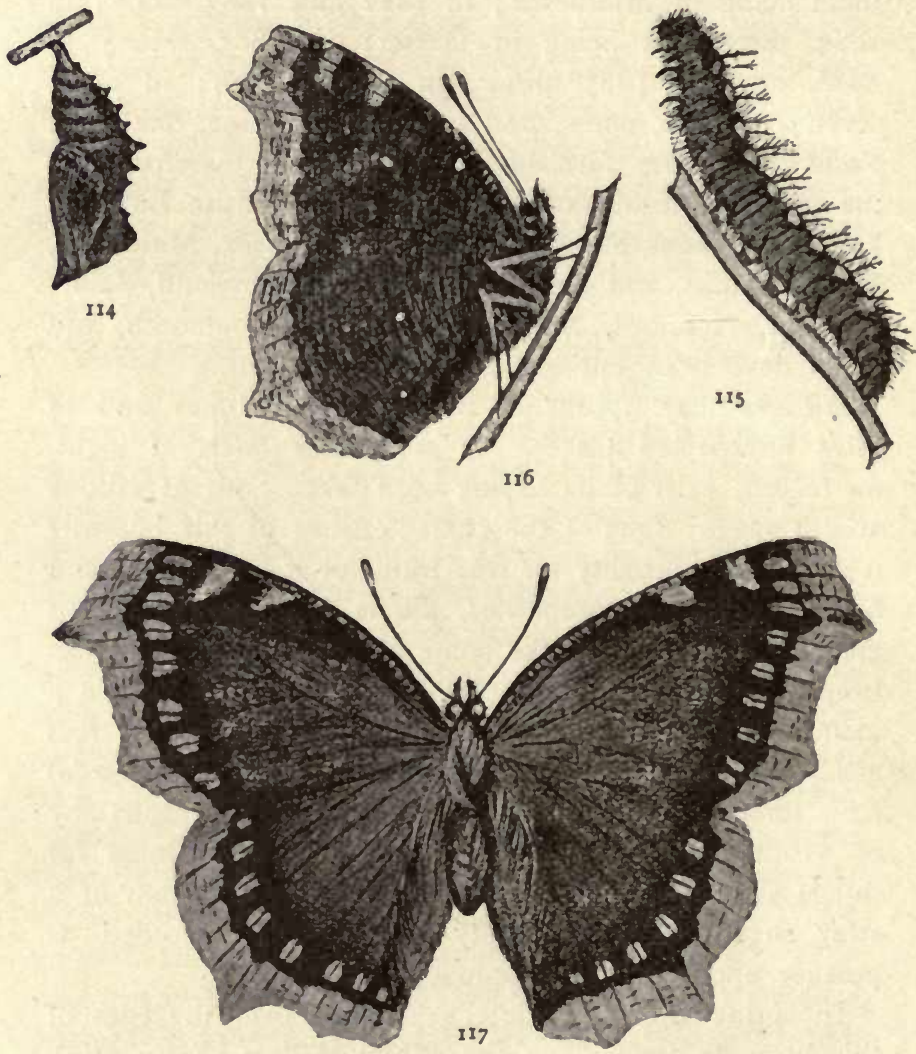

VANESSA ANTIOPA.

segments seven to twelve, and four on the thirteenth. The ground-colour is velvety-black, with a dark red 
blotch on segments four to eleven, and all the body except these blotches is densely covered with soft grey hairs. The black dorsal line is continued, though much narrower, through the coloured blotches. The head and legs are black and the claspers reddish.

The portly pupa (Fig. II4) has its ears rather short, the thoracic bump pronounced, and the back of the abdomen much arched and bearing a mid-dorsal line of tiny points. On each side of this is a subdorsal line of much longer spines, the pair on the highest part of the abdomen being longest. Each wing-case bears three projections, two forming a lateral keel to the thorax and the other being at the tip of the wing-case. The colour is brown, freckled with darker brown. All the points are black-tipped and each segment of the abdomen bears laterally several black dots. The under-surface of the anal hook is black. The specimen from which this description was made measured rin. in length.

The costal margin of the fore-wings of the imago (Figs. II 6 and II7) is nearly straight till it approaches the tip, and the hind-margin of each of the wings bears a couple of prominent angles. The colour of the upper surface is deep chocolate, edged from the tip of the forewings to the anal angle of the hind-wings with creamywhite speckled with black. Near this band the groundcolour becomes almost black and contains a row of blue spots. There are two cream-coloured spots on the costal margin of the fore-wings near the tip. The under-surface (Fig. I16) has the same cream-coloured markings, but within the band the colouring is similar to that of the whole of the under-surface of $V$. io. The pale margin varies considerably in depth of colouring; some specimens having it nearly white, and others of quite a yellow tint. The former used to be looked upon as natives, and 
the latter as immigrants. It seems likely, however, that all may have yellow borders at first, which become paler after hibernation.

V. atalanta, Linn. (Red Admiral) (Figs. II 8 to I2I), is another very powerful flyer, and at times given to soaring. It is, perhaps, more difficult to take than the Peacock, unless it should be observed sucking the nectar from flowers. So intent is it sometimes in this occupation, that it may be quite easily removed from the blossom with the fingers. Like others of its genus it sometimes visits at night the sugar that has been placed as a lure for moths. Though usually very generally distributed throughout Great Britain and Ireland, it is very much more common in some seasons than in others. During last season-1892-atalanta favoured us with its presence in more than the usual numbers.

The eggs are laid in May and June on the common Nettle (Urtica dioica), while the larvæ have also been seen feeding upon Pellitory-of-the-Wall (Parietaria officinalis). In June, July, and August the larvæ are found, and the chrysalides in the last two months, while the imagines are on the wing from August until October, and again till June after the winter's sleep is past.

When full-grown, the larva (Fig. IIg) is about rain. long, and has the characteristic spines. It feeds in a tent-like structure formed of the leaves of its food-plant, held together with silk. Though specimens often closely approximate to cardui in general appearance, the spines, which vary greatly in colour, are longer than those of that species, but not so long as those of io or antiopa. Their disposition is four on the third and fourth segments, seven on segments five to twelve, and four on the thirteenth. So far as the ground-colour is concerned, this varies through black-brown, russet-brown, and 
soft grey, to greyish-green. There are usually two yellow lateral stripes, the upper being narrower than the lower,
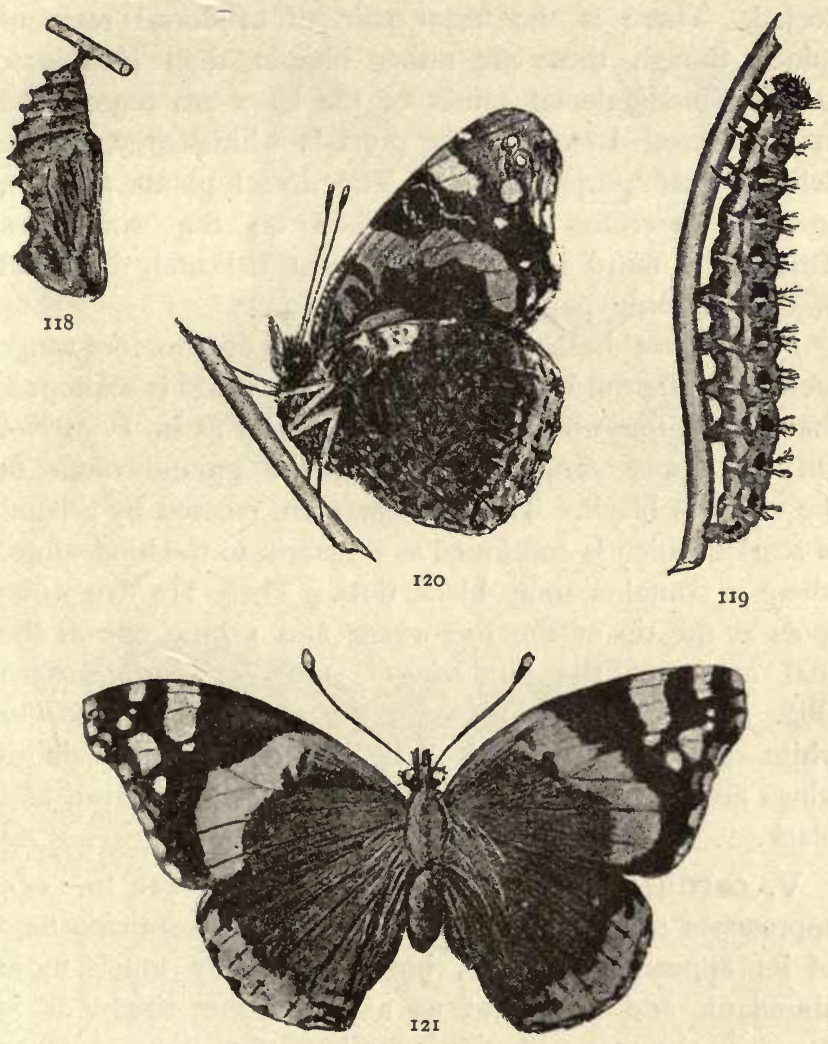

VANESSA ATALANTA.

and on each segment is a pair of distinct black blotches one on each side. The head and legs are black, and the claspers brown like the ventral surface. 
The plump pupa (Fig. II 8 ) is about rin. long, with the ears on the head reduced to rounded prominences. The thorax bears a central protuberance, and is laterally keeled. There is the usual pair of subdorsal rows of spines, though these are rather blunter than in urtica, and the medio-dorsal spines of the larva are reproduced in miniature. In colour the pupa is whitish-grey, with a delicate pale purple bloom. The dorsal points are gilt, and the nervures faintly outlined on the wing-cases. This to my mind is one of the most delicately beautiful of our butterfly pupæ.

$V$. atalanta has the costal margin of the fore-wings arched; while the hind-margin of all the wings is scalloped, that of the fore-wings having a concavity as in V. cardui. On the upper surface (Fig. I2I) the ground-colour of the wings is black. The fore-wings are crossed by a band of scarlet, which is continued as a margin to the hind-wings, where it contains some black dots. There are five white spots at the tip of the fore-wings, and a blue one at the anal angle of the hind-wings. On the under-surface (Fig. 120) the fore-wings have the scarlet band and the white spots together with a little blue, while the hindwings are a delicate mixture of cream, blue, brown, and black.

V. cardui, Linn. (Painted Lady) (Figs. 122 to 125 ), approaches somewhat to $V$. antiopa in the capriciousness of its appearance; it is, however, usually much more abundant, and does not as a rule occur singly, as is generally the case with the latter butterfly. Some seasons it may be particularly scarce throughout the kingdom, and altogether absent from many localities; while in other seasons again it occurs quite plentifully. In 1892 after the appearance of a considerable number of hibernated specimens in the spring, entomologists were delighted 
to find a corresponding abundance of the fresh brood in the autumn. It may be expected throughout Great Britain and Ireland.
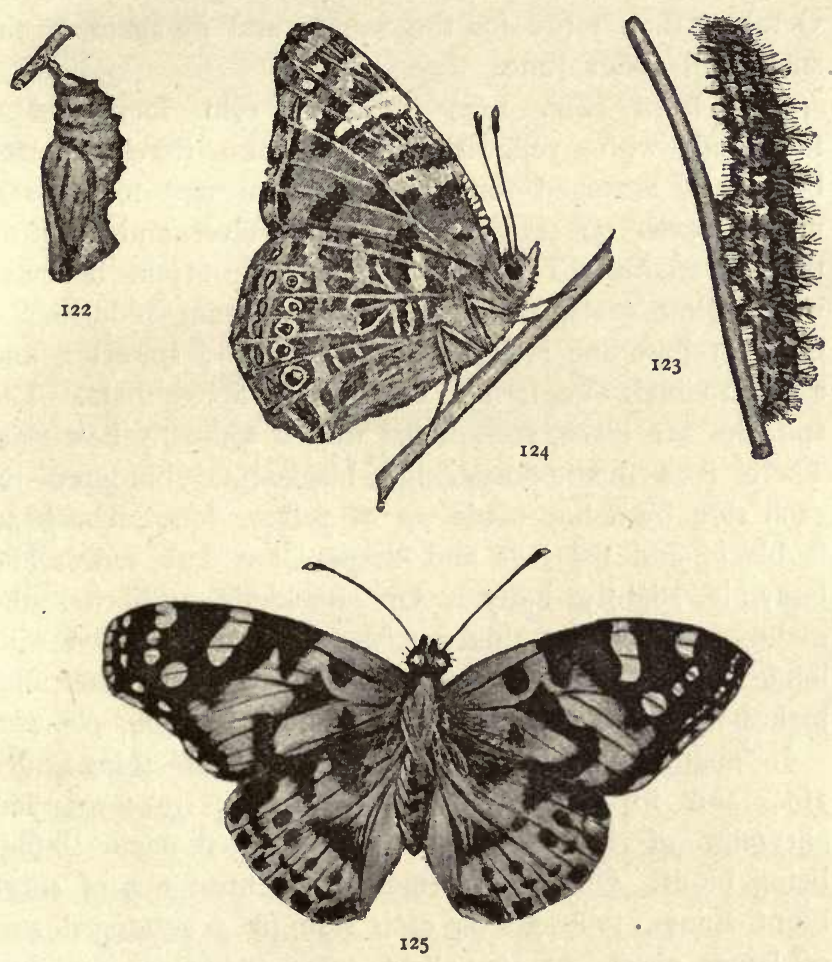

VANESSA CARDUI.

As may be gathered from the specific name, the Thistle is the plant on which the eggs are usually deposited, but both the Nettle (Urtica dioica) and the Mallow (Malia sylvestris) are sometimes visited. The females commence 
ovipositing about June, and the larvæ first appear the same month, but may be found till September. The first chrysalides are to be obtained in July, and the imagines come out in August. They are on the wing till October, then retire for the winter, and fly again in the spring till about June.

The larva (Fig. 123) is about $1 \frac{1}{2}$ in. long, and is furnished with yellowish-white spines (having black branches), arranged four on the third and fourth segments, seven on segments five to twelve, and four on the thirteenth. The ground-colour is black, bedewed with yellow spots, the ventral surface being reddish. A bright yellow line is found just below the spiracles, and a much fainter one, formed of dots, just above them. The spiracles are black, surrounded with a whitish-yellow ring. There is a medio-dorsal thin black line, bordered on each side by a line made up of yellow dots. The head is black, and the legs and claspers are dark red. The body is slightly hairy. On Buckler's authority, the mallow-fed larva of this species is densely covered with long hairs. Like the larva of atalanta, this caterpillar makes itself a shelter with the leaves of its food-plant.

In length the pupa (Fig. I 22) measures something under rin., and in outline closely resembles the rounded chrysalis of atalanta, the ears and thoracic bump being blunt. On the abdomen is a central row of short blunt spines, followed on each side by a subdorsal row of larger ones. As to colour, some specimens are dull brown, black dotted, while others are much paler and of a greenish tinge. The former have some dark markings; and the chrysalis of cardui is always noted for its golden appearance.

The costal margin of the fore-wings of the imago (Fig. 125) is arched, and the hind-margin of all the wings 
is scalloped; while the concave general outline of the hind-margin of the fore-wings gives the insect a very graceful appearance. The ground-colour consists of various shades of reddish-brown, irregularly marked with black. There are five white spots near the tip of the fore-wings, and five black ones near the margin of the hind-wings. On the under-surface (Fig. 124) the forewings are marked much in the same way, but in somewhat lighter tints. The hind-wings are delicately pencilled with brown and cream, and there are five beautiful eyespots corresponding to the five black spots on the upper surface. Contrary to usual custom, the under-surface is more beautiful than the upper.

\section{Limenitis, $B d v$.}

The genus Limenitis is represented in Britain by one species only, the group of butterflies to which this genus belongs being more plentiful in the East. The imago has but four perfect legs, the anterior pair being unfitted for walking. As in the Vanessas, the larva is spinous, and the pupa angled; the wings, however, are not angled but scalloped. The larva is suspended, head downwards, by the anal extremity.

L. sibylla, Linn. (White Admiral) (Figs. I26 to I29), has little relationship to the Red Admiral, notwithstanding the similarity of their common names. There is, however, some kind of resemblance between the two insects; both have a very dark smoky-black ground-colour, crossed in the case of the Red Admiral by a scarlet band, and in the butterfly before us by a white one. The bands, however, do not correspond, for they are in opposite directions. The under-surfaces of both, though bearing no resemblance to one another, are exceedingly beautiful, forming in each case a mosaic of most delicate colouring. 
The White Admiral is, unfortunately, not at all common. It is unknown in Scotland, and indeed in England except in the southern part. It has been taken in Lincolnshire, Suffolk, Essex, and Kent, on the east; in Sussex, Hampshire and the Isle of Wight, and in Dorset, on the south; and in the following inland counties : Surrey, Buckingham, Northampton, Gloucester, and Worcester; but these should, perhaps, now be narrowed down to Hants and the Isle of Wight, Northants, Suffolk, and Essex. In those localities it may be sought for in the rides and glades in oak-woods, sailing along which its peculiarly graceful flight has always been a subject of delight to the lover of Nature. Like the Fritillaries, it is fond of settling on the brambleflowers, and may there be taken if the net is handled with the requisite skill.

The eggs are laid in July, on the upper leaves of the Honeysuckle (Lonicera Periclymenum). The larva comes out in a fortnight, and, after feeding for a time, hibernates till the spring. Newman has graphically described how each little larva draws together, to make a winter house, the edges of the leaf on which it has been feeding, having first fastened the leaf to the stem to prevent its falling to the ground in the autumn. In this hammock, which hangs free when the leaf has broken away from the stem, it passes securely through the winter. It begins feeding again in April, and is full-fed by the end of May or beginning of June. The pupa may be found during June, and the imago comes out at the end of it or beginning of July, and is on the wing during the latter month in oak-woods in the southern part of England, as mentioned above.

The larva (Fig. I 26), which is $1 \frac{1}{2}$ in. or more in length, is spinous, but not in the same way as are the larvæ 
of the Fritillaries or the Vanessas, since the spines occur only on the dorsal surface. There are no spines on the second segment, two long ones on the third, fourth, sixth, eleventh, and twelfth, four short ones on the thirteenth, and two short ones on all the rest except the head. The
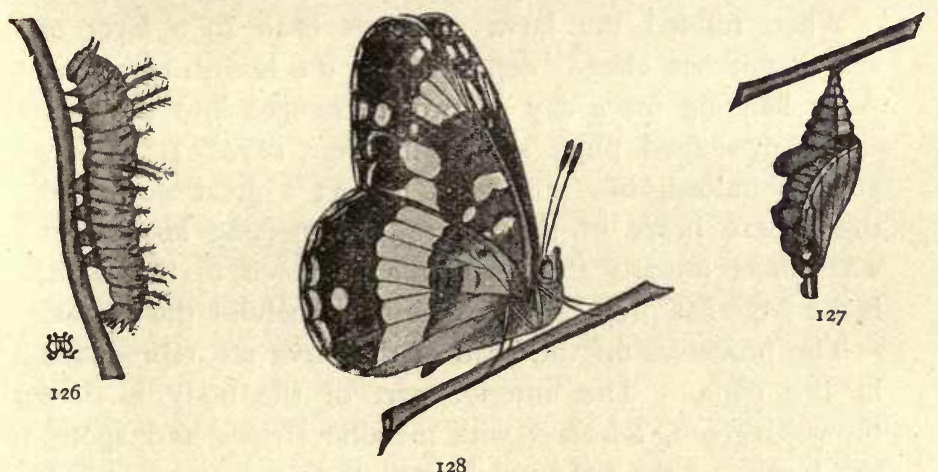

126

128

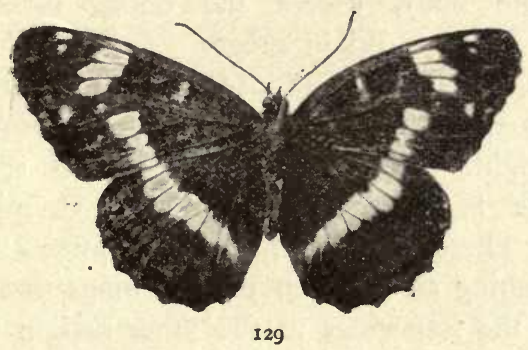

LIMENITIS SIBYLLA.

spines are rufous, with light bases and pink tips, and bear black hairs. The head is flat, pinkish, bristly, and produced above into two ear-like processes. The groundcolour of the larva is dark green dorsally, paler laterally, and bright green on the ventral surface. The legs are 
brownish, and the claspers pale green, with a pinkish circle round them near the body. The back and sides of the caterpillar are sprinkled over with yellow warts. There is a lateral yellowish spot on each segment, and a whitish line below the spiracles, which are white. The divisions between the segments of the body are distinct.

When full-fed the larva suspends itself to a layer of silk that it has already deposited on the midrib of a leaf. After hanging for a day or two it changes into the very singularly-shaped pupa shown in Fig. 127. It is very angular indeed, the wing-cases project a great deal, and the thorax bears in the centre a projecting keel. But what most imparts the singular appearance to the larva, is the large flat projection on the back behind the thorax.

The processes on the head of the larva are reproduced in the pupa. The anterior part of the body is dark brownish-green, adorned with metallic stripes and spots; the horns on the head are brown, and so is the posterior part of the body, except the dorsal surface of the abdomen, which is bright green.

The wings of the perfect insect (Fig. 129) are scalloped, and the costal and hind margins of the fore-wings are nearly straight. The upper surface is dark smoky-brown. The fringe is white, except at the extremities of the nervures. There is a band of about fifteen bluish-white spots stretching across each pair of wings from the costal margin of the fore-wings to the inner margin of the hind ones. There are also four other white spots on the fore-wings. The chief beauty of the insect, however, is to be found on the under-surface (Fig. 128), where the white spots are reproduced with a few additions to their number; but the ground-colour is a rich sienna-brown, tinged here and there with a darker brown, and bearing a number of black dots and bars. The base and inner 
margin of the hind-wings are whitish-blue. The knobs of the antennæ are tipped with brown, and but slightly thickened. The sexes are similar.

A variety sometimes occurs in which the arrangement of the under-surface is very much altered, and in which the upper surface is without the white spots.

\section{Apatura, Fabr.}

In the genus Apatura the larva seems to be intermediate between the genus Limenitis and the Ringlet group. It resembles the latter in having no spines, and in tapering towards both extremities, especially towards the anal one, which is slightly bifid. In shape it is limaciform, or slug-like. It differs from the Ringlets, and resembles the last genus, Limenitis, in having on the head two processes somewhat resembling ears. The pupa is neither angled nor spine-bearing; it is very much flattened laterally, and is suspended by the tail. The imago somewhat resembles that of the last butterfly (Limenitis sibylla), but it has one or two eye-spots, which remind us of the Ringlet group. The wings are large and powerful, and the flight is strong. There are but four legs adapted for walking, the anterior pair being only slightly developed. The genus is represented in Britain by one species only.

A. iris, Linn. (Purple Emperor) (Figs. I 30 to I33), no doubt derives his English name from the purple robe with which he is adorned, but the "Empress," though similarly" marked, is without the purple sheen which gives the glory to her mate. This monarch of the butterfly tribe adopts as his throne the topmost branch of an oak, where he sits aloft in the sunshine, occasionally sailing away almost out of sight, doing battle with his peers, the monarchs of the neighbouring oaks, and returning as a rule to the identical spray from which he started. While the Emperor is there 
enthroned, it is clear that the collector, however much he may covet the prize, must be satisfied with the view alone. To sweep him from his seat, a net with a handle 20 ft. or more in length used to be recommended-a handle, of course, that could be fitted together and taken to pieces again like a fishing-rod or the handle of a chimney-sweep's brush. But apart from the difficulty of carrying such a weapon to the field of operations it must have been extremely awkward to use, and few indeed, I fancy, would be the Emperors captured by its aid. The collector obtains specimens now by taking advantage of a well-known though very un-butterfly-like taste this insect has acquired. Most butterflies feed, if they feed at all, on the nectar of flowers, and possibly this one does sometimes, for he has been taken at sugar; but the Emperor has often been easily caught while intently regaling himself from a muddy pool, from animal droppings, or from the dead and putrefying bodies of stoats, rabbits, birds, and so on, that are usually to be found in woods. Knowing this, and knowing also that Emperors are to be found in the locality, the would-be possessor may usually obtain them without much difficulty.

The Purple Emperor, however, is not to be found everywhere. It should only be sought for in oakwoods, and in those only in the midland, southern, and eastern counties of England; that is to say, roughly speaking, south of a line drawn from the Humber to Devonshire. The following counties have been mentioned as supplying specimens : in the east-Lincoln, Suffolk, Cambridge, Essex, and Kent; in the south-Middlesex, Surrey, Sussex, Berks, Hants and the Isle of Wight, Wilts, Somerset, Dorset, and Devon; in the midlands, Bedford, Huntingdon, Buckingham, Oxford, Northampton, Nottingham, Warwick, Leicester, Hereford, Gloucester, and Monmouth. 

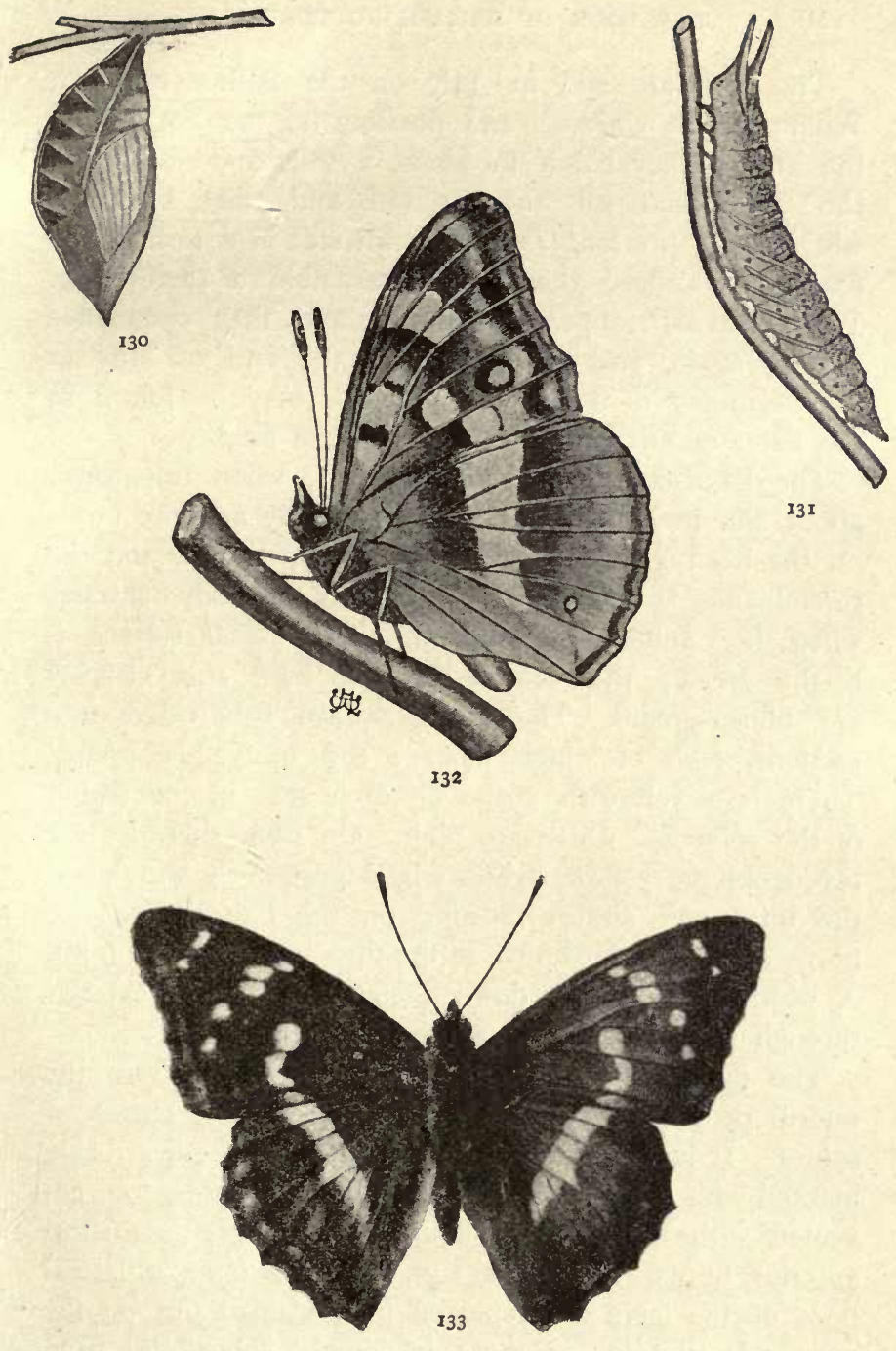

APATURA IRIS 
The eggs are laid in July on the Sallow or Goat Willow (Salix Caprea), and possibly on the Poplar and the Oak. They hatch in about a week-and-a-half, and the larvæ feed till the autumn, and then hibernate when about $\frac{1}{2}$ in. long, fastened with silk in a fork of the food-plant, where they much resemble a small twig. When leaves reappear on the Sallow, they commence feeding again, and are full-fed at the end of May or the beginning of June; the chrysalis may be found in the latter month, and the imago in the next.

The handsome larva (Fig. I3I) is, when full-grown, about 2 in. in length. The tapering body and the horns on the head give it a very slug-like appearance, and the resemblance is heightened by the way the body contracts when the animal is annoyed. The dorsal surface is bright green; the ventral surface, legs, and claspers are bluish-green. The segments are subdivided into sections, each of which bears a row of yellow points. There is a yellowish stripe on each side in the region of the spiracles, which are pink. On each side also are seven oblique yellow stripes edged posteriorly with pink, the third pair almost meeting on the back. The two horns are green, brownish at the tips, and bluish in front. A whitish line passes down them behind, and extends through several segments along the back.

The pupa (Fig. 130), which is suspended from the midrib of a leaf of the food-plant, is without angles or spines. It is whitish-green in colour, all the edges being marked with even lighter lines. The wing-cases, too, are veined with the lighter colour. There are two short anterior horns, with dark tips, and the oblique lateral lines of the larva are repeated in a whitish tint on the pupa. It is $1 \frac{1}{4}$ in. or more in length, about $\frac{1}{2}$ in. from back to front, but only about $\frac{1}{4}$ in. through from side to side. 
The costal margin of the fore-wings of the imago (Fig. I33) is convex, and the hind-margin concave and scalloped; the hind-wings are scalloped. The groundcolour is smoky-brown above, and the fringe white. There is a somewhat interrupted white band extending from the centre of the fore-wings to near the inner margin of the hind-wings, as well as about nine white spots near the tip of the fore-wings. There is a light line near the outer margin of all the wings, and in this region the ground-colour is darker. A reddish mark will be seen near the tip of the hind-wings, and others at the anal angle, near which is a black spot circled with red and having a few blue scales in the centre. The under-surface (Fig. I $3^{2}$ ) is much more beautiful than the upper. The ground-colour is very much lighter. The white markings resemble those on the upper surface; but there is a band of rich dark brown on each side of the white stripe on the hind-wings, and three patches of the same colour are to be seen on the costal margin of the fore-wings. The hind-margin of the hind-wings is pinkish-white, while the eye-spot of the upper surface is repeated, but smaller, and with a brighter blue centre. There is besides a much larger eye-spot on the undersurface of the fore-wings-black surrounded with orange, the centre being blue as before. The body, legs, and palpi are nearly white; the tongue is pale green. The male, in certain lights, has its wings suffused with a rich, deep purple-hence the common name. In the female, the purple glow, as stated above, is absent, but she is often larger than her mate.

$A$. iris varies somewhat in the development of the white markings, and specimens now and again occur in which they are nearly or quite absent. 


\section{Danais, Fabr.}

D. erippus, Cr. (Black-veined Brown) (Figs. I 34 and I35), though probably but a visitor from over the Atlantic, is certainly a welcome one, for it is a grand insect, reminding us both by its size and by its appearance of those which we are wont to consider as exotics. As a matter of fact, it has a wide geographical range, extending from North Canada to the Amazon, and is evidently of a very accommodating disposition, for we find it naturalised in several parts of Australasia, and in 1876 it made its appearance in England. In that year three were taken in Sussex, one at Poole, and one at Neath in South Wales; in I88I a male was taken near Maidstone on 21 st September; in 1885 one was taken in Dorset, one at Plymouth, five in Cornwall in September, and one at Ventnor; in $\mathbf{1} 886$ five were taken -one at Swanage in August, one at the Lizard, another at Swanage in September, a male at Bournemouth, and a specimen at Castle Martin, Pembrokeshire. Besides these, one was taken in October, 1886 , in Guernsey, and one the same month in Gibraltar, while one had been taken in September of that year at Oporto. In $\mathbf{1 8 8 7}$ two were captured in September at Worthing, and one at La Vendée in France.

In St. Louis, U.S.A., the eggs are laid in early May, and the imago appears about mid-June, and again, from a second brood, in October. The females from the latter brood hibernate till spring. Food-plants in America are various species of Asclepias; perhaps in England the larvæ might feed upon the Periwinkle (Vinca major and $V$. minor) or the Oleander (Nerium).

In colour, the handsome larva, whose appearance may be gathered from Fig. 134, is black, white, and yellow. 
The pupa is suspended, as in the Vanessas, and this stage lasts but a short time.

Fig. I 35 was obtained from a photograph of the male imago. The ground-colour is rich orange-brown, the

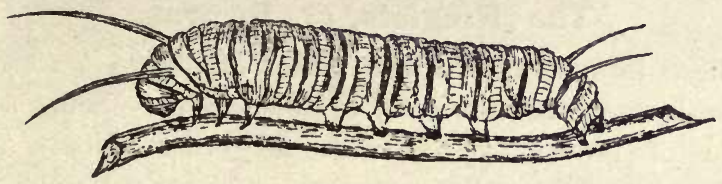

134

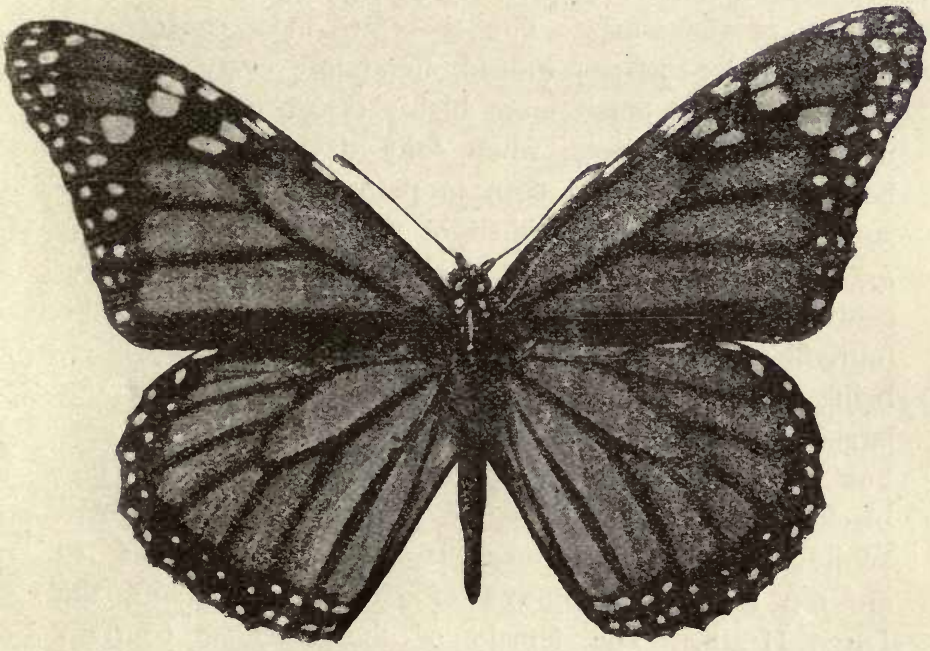

I35

DANAIS ERIPPUS.

nervures being black, which colour also forms a border of considerable depth round the insect. The black border contains numerous white spots. The undersurface is very similar, but much lighter on the hind- 
wings. The insect often expands as much as $4 \frac{1}{2}$ in. The female may be known by its broader nervures and by the absence of a black tuberculous spot which is found on the hind-wings of the male.

\section{The Ringlets, or Browns.}

These form a well-defined group of eleven butterflies, all, with one exception - the Marbled White-being some shade of brown marked with no other colours than black, white, and ochreous-yellow. All are adorned with a larger or smaller number of eye-spots near the hindmargin of the wings. The spots are most conspicuous on the under-surface; indeed, in almost every case the under-surface is much more highly ornamented than the upper. The eye-spots, when fully developed, are very beautiful, and may be seen in perfection on the undersurface of a good specimen of the Ringlet (Epinephele hyperanthes). They are jet-black, with a tiny pure white centre, and surrounded with a pale yellow ring. All the butterflies of this group are small or middle-sized, and, being sober-tinted, cannot compare with some of our larger butterflies, or even with the Blues and Coppers; but yet many have a quiet beauty of their own. The black marbling on a creamy ground of the Marbled White (Melanargia galatea) is very pleasing, and so are the rich warm browns of Epinephele tithomus, the Large Heath. The female of the Grayling (Satyrus semele), which often attains a considerable size, has a very richly chequered under-surface; while the eye-spots of the Wall butterfly (Pararge megara)-five concentric circles round a white centre-are very delicately beautiful. The downy appearance of the two dark butterflies, the Northern Brown (Erebia athiops) and the Mountain Ringlet ( $E$. epiphron), and of the pale Marsh Ringlet 
(Canonympha typhon), give one the idea that they require protection against the cold, which is perhaps the case.

In the whole group there is a great similarity in shape and often in colour of the larvæ, which are without spines and taper towards both extremities, but especially towards the anal one, which is bifid. All feed on grasses and pass the winter in the larval stage.

The pupæ are stout, with broad heads, and practically without spines or angles. Normally they are attached by the tail to the food-plant; but frequently they are not suspended at all, and the wrinkled skin of the larva often remains attached to the anal extremity of the pupa.

The imago usually has elongated knobs to the antennæ, and has only four perfect legs adapted for walking. All are weak on the wing and easily caught. In several species the male is distinguished from the female by the presence on the former of a dark bar on the upper surface of the fore-wings near their base. The eleven species are distributed amongst six genera: Melanargia, Erebia, Pararge, Satyrus, Epinephele, and Cononympha. Erebia ligea (Arran Brown) used to be taken in the Isle of Arran, but is not now usually considered as British. Epinephele hero has also been claimed by some as a native.

\section{Melanargia, Meigen.}

M. galatea, Linn. (Marbled White) (Figs. I 36 to r 39 ), is the only British species of its genus. It is not a White, although in colouring it somewhat resembles one, and its common English name would seem to class it amongst them. Its relationship may be known by its possessing but four perfect legs and by the presence of eye-spots on the wings, which, however, are not very conspicuous 
on the upper surface. On the wing it closely resembles a female Small or Green-veined White, but its flight is weaker, although that of the White is not very strong.

The Marbled White is an extremely local butterfly, but sometimes common over a very restricted area. It is not a wood insect, and seems to prefer rough, broken ground, like a chalk or limestone hill-side. It need not be sought on such ground exclusively, for I found a considerable number on one occasion, when the sun was not shining, at rest on the grasses or rushes growing in a swampy spot a few miles from Abingdon in Berkshire. Their position seemed to have been taken up designedly with a view to concealment, for at a short distance it was difficult to distinguish the butterflies from the inflorescence of some of the rushes and grasses. An instance this, probably, of protective resemblance.

Galatea occurs locally in all the English counties except nine or ten north-midland and northern ones. It is, however, found in Yorkshire. In July the eggs are laid amongst the grass. They are hatched in about three weeks; but the young larvæ hibernate early near the roots of the grass, and begin feeding again about the end of April. They are full-fed about the beginning of June, in which month the chrysalis may be found. The imago comes out in July.

The larva (Fig. 137) is about $1 \frac{1}{4}$ in. in length, the head is large, the tail forked, and the body slightly dilated along the sides. The segments are not clearly defined, nor are the sections into which each segment is divided. The ground-colour is dingy ochreous-yellow, sometimes with a dull greenish tinge. There is a rather dark dorsal stripe, and along the spiracular region a band slightly darker than the ground-colour, bounded above and below by a lighter line. The ventral surface, legs, 
and claspers are dull ochreous-yellow, resembling the ground-colour, and the mouth and spiracles are black. The body is covered with minute brown dots and numerous pale hairs.

The pupa (Fig. 136 ) is of the shape common to the group to which it belongs-short and stout, without
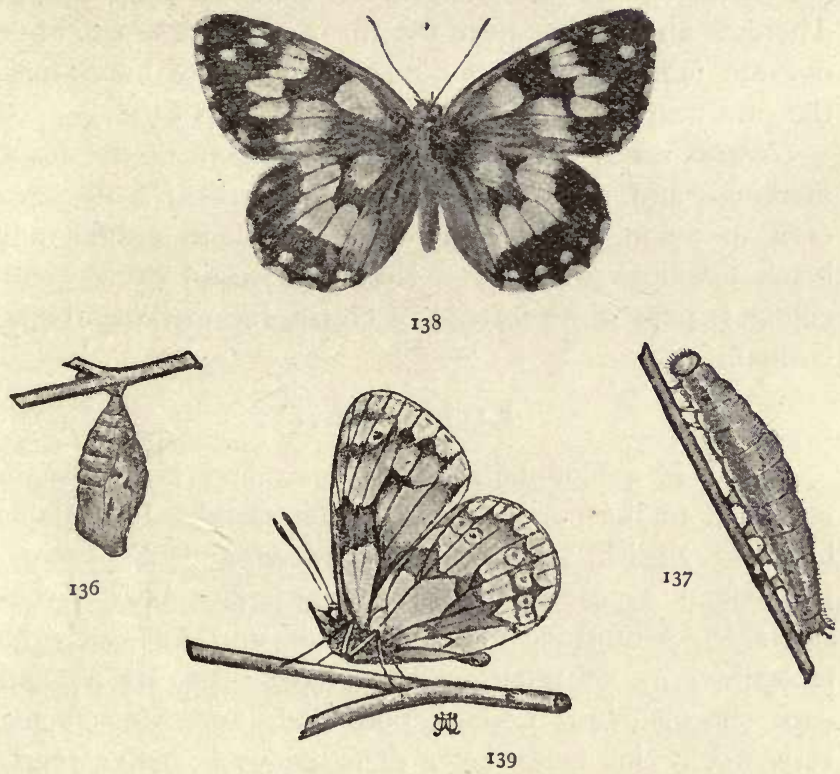

MELANARGIA GALATEA.

angles or points. It is frequently unsuspended. The colour is whitish-brown, the wing- and antennæ-cases being freckled with pale brown; the pupa is marked in places with yellow.

The imago (Fig. 1 38 ) has the costal margin of the forewings convex, and the hind-margin of all the wings slightly 
scalloped. The ground-colour is creamy-white and the markings are black, the black and white covering about equal portions of the total area. The arrangement of the two colours can be seen from the illustration. On the under-surface (Fig. 139) the coloration closely resembles that of the upper surface, but many of the black markings are here represented by greyish ones or lines simply. There is an eye-spot near the tip of the fore-wings, while five are found along the hind-margin of the hind-wings, the one nearest the anal angle having two eyes.

Galatea varies a little in the development of the black markings, and mention has been made in The Zoologist of a specimen pure creamy-white, in colour without any black markings whatever. Now and again the groundcolour is pure white instead of cream, the markings being normal.

\section{Erebia, $B d v$.}

Erebia is a mountain-loving genus, and is in Britain restricted to the northern part of the island. It contains but two British species, $E$. epiphron and $E$. athiops. In general appearance the two butterflies bear a considerable resemblance to one another, and will easily be recognised as congeners. They have black bodies and dark chocolate-brown wings, both body and wings being very woolly in appearance. The genus is better represented in mountainous districts on the Continent; the species, however, are often local and on the wing for a very short time.

E. epiphron, Knoch, E. cassiope, Fabr., possesses two common names, the Mountain Ringlet and the Small Ringlet; but as Cononympha typhon is sometimes called the Small Ringlet, the former name in this case seems to be preferable. This is the only really Alpine 
butterfly found in Britain, for the other species of the genus frequents much lower ground. It should be sought for in marshy hollows on the mountain-sides in Scotland and the north of England, and in one locality at least has been taken at a height of $3000 \mathrm{ft}$. above sea-level. Its flight, which only takes place when the sun is shining, is slow and interrupted. Epiphron frequently settles and falls to the ground among the grass, where the dark colour of its wings makes it a difficult object to find. If possible, specimens should be obtained soon after leaving the chrysalis, for the wings are very easily damaged.

In England epiphron is found in the Lake District; that is, Westmoreland, the north of Lancashire, and the south of Cumberland. There it has been taken in many districts, of which the following have been mentioned: Sprinkling and Styehead Tarns, Gable Hill, mountains near Ambleside, Helvellyn, and Langdale Pikes. In Scotland it has been taken at Rannoch in Perthshire, on Ben Lomond and Ben Nevis, and at Loch Vennachar near the Trossachs.

The larva appears to pass the winter in a state of hibernation, like the rest of the Ringlet group. The perfect insects are out from about the middle of June till the beginning of August, the males being a little earlier than the females. Where found, epiphron is usually plentiful, but very local.

The larva, which feeds on grass, has been described by Newman as pale green in colour, with numerous darker green longitudinal lines shading into the groundcolour, and with a well-defined white line along each side in the region of the spiracles.

The pupa, which is of somewhat stumpy proportions, is light green anteriorly, and dingy white posteriorly, 
with a brown dorsal streak on the thorax. There are, besides, a few other dark brown marks.

The costal margin of the fore-wings of the imago (Fig. 140) is convex, while the hind-margin of all the wings is rounded. The colour of the upper surface is a deep chocolate-brown, with a somewhat indistinct coppercoloured band across all the wings parallel to the hindmargin. This band is interrupted at the nervures, and frequently assumes the form of circular coppery patches, especially on the hind-wings. Each of these patches usually contains a small black spot. The colouring of
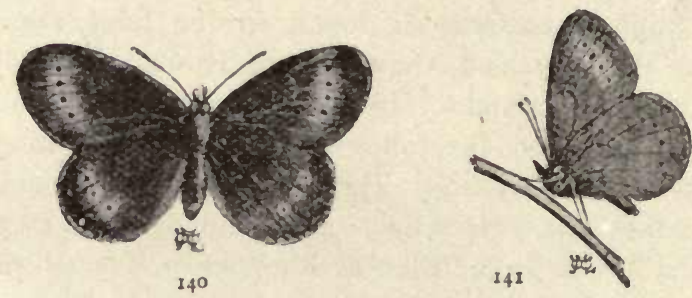

EREBIA EPIPHRON.

the under-surface (Fig. I4I) very closely resembles that of the upper; but the coppery band is even less distinct, especially on the hind-wings, where also the black spots are extremely small. The sexes are similar. Epiphron is variable in size and in the development of the coppery patch and the black spots, which last may have white centres.

E. æthiops, Esper; E. medea, Hübner; E. blandina, Fabr. (Northern Brown or Scotch Argus) (Figs. 142 to 145 ), is a rather larger butterfly than the last-its wings expanding from $\mathrm{I} \frac{1}{2}$ in. to 2 in. - but somewhat closely resembles it. Like the last, too, it is 
generally a mountain-loving insect, though it does not affect such elevations as its congener sometimes reaches, for it is seldom found more than 8ooft. above sea-level. It delights in the broken heathery or ferny spots on the lower mountain-sides as well as in marshy spots in similar localities.

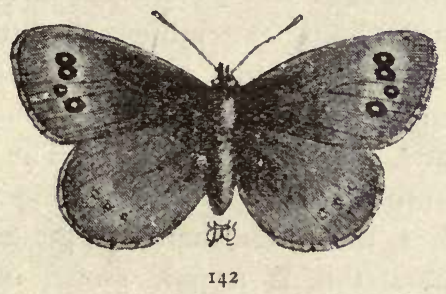

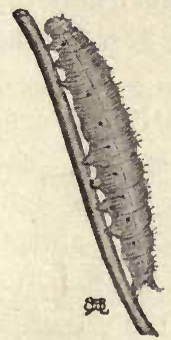

144

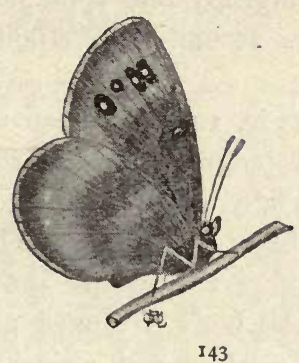

I43

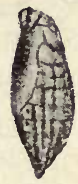

145

EREBIA ÆTHIOPS.

Some few years since, athiops was considered an extremely rare butterfly, and even now cannot by any means be spoken of as common. The most that can be said is that it is not uncommon in many parts of Scotland, and that it is taken in several localities in the five or six northern counties of England, and commonly at a few spots, such as Castle Eden Dene, in Durham, and Grange, in Lancashire. 
The eggs are laid at the end of the summer, and hatch in about a fortnight. The young larvæ feed on several kinds of grass till, after the second moult, they hibernate about October. They are full-fed at the end of the following June, and the imago is on the wing in July and August.

The larva (Fig. 144) is stout, thickest in the middle, and tapering towards both extremities, the anal one being slightly bifid. The segments, which are not very distinct, are subdivided into five sections. The body is covered with small warts, emitting tiny hairs. The ground-colour is whitish-brown; there is a dark medio-dorsal line, bordered with a tint paler than the ground-colour. On each side below this is a pale stripe, bordered below with a darker margin. The spiracles are black, and the legs and claspers resemble in colouring the rest of the body.

The chrysalis (Fig. 145) has been described by Buckler as about $\frac{5}{8} \mathrm{in}$. in length, the wing-cases being long, the body stout, especially in the middle, tapering to the tail, and ending in a blunt, flat spike. The thorax is rounded, and the head and eye-cases are prominent. At first the anterior part of the body is pinkish-grey, and the posterior dull yellow with dark dorsal stripe and other lines, and spiracles also as in the larva; but later the anterior part changes to a dark brown.

The costal margin of the fore-wings of the imago (Fig. 142) are convex, as is also the hind-margin; the hindwings are very slightly scalloped. The fringe is rather light. The ground-colour is a deep chocolate-brown crossed on each wing by a band of a coppery colour. This contains on the fore-wings four black spots, usually white-centred, the third from the costal margin being less constant than the others. On the hind-wings the nervures 
divide the band into compartments, in which may be found about four somewhat indistinct eye-spots. The under-surface (Fig. 143) of the fore-wings resembles very closely the upper surface. The hind-wings show four bands of different shades of brown parallel to the hind-margin. The second from the margin is lightest, of a greyish colour, and contains about four tiny white spots; the next band inwards is the darkest. A long series of this butterfly should be obtained if possible, for it is subject to considerable variation, especially in the eye-spots. The female is lighter than the male, especially on the under-surface and in the coppery band on the upper surface.

\section{Pararge, Hüb.}

The genus Pararge contains two species, egeria and megara, about equal in size and similar in markings, though egeria is much darker than the other. They have hairy eyes.

P. egeria, Linn. (Speckled Wood Butterlly, Wood Lady, or Wood Argus) (Figs. 146 to 149), is a sobertinted butterfly of middle size. It is a wood-loving insect, to be found in suitable districts throughout England and the south of Scotland. It is, perhaps, not so common as is generally supposed.

The eggs, which are laid singly late in the summer, are hatched in less than a fortnight. When partly grown the young larvæ hibernate, and they are full-fed about the end of March. The pupæ may be found early in April, and the imagines come out towards the end of the month. There appears to be a summer brood also, which produces the larvæ that live through the winter. 
The larva (Fig. 147) is about $1 \frac{1}{4}$ in. or rather more in length. The head is large, and the body tapers towards both extremities, the anal one being bifid. The divisions between the segments are rather distinct, the segments themselves being subdivided into sections. The surface of the head and body is covered with tiny points and
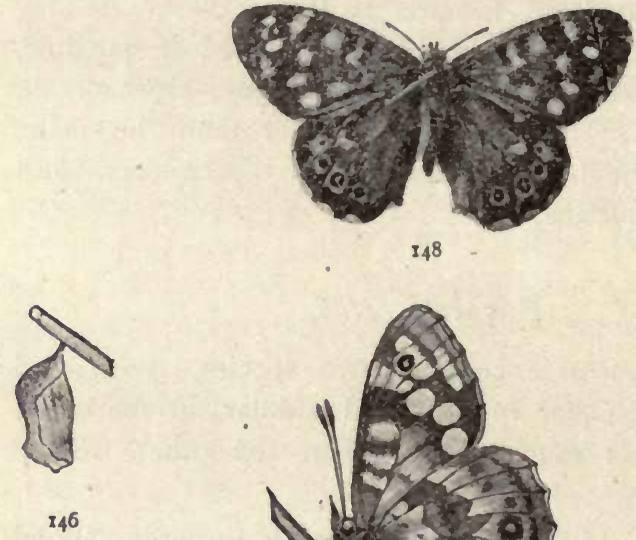

$34^{8}$

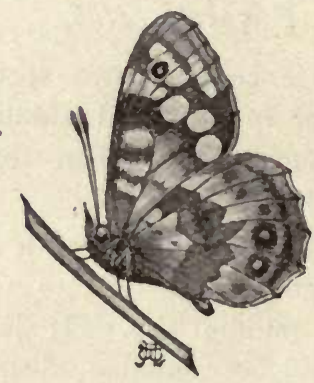

149

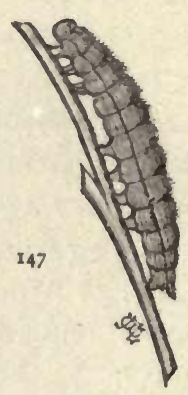

PARARGE EGERIA.

short, stiff hairs. The colour of head, body, legs, and claspers is green, inclining sometimes to a brownish tinge. There is a dark medio-dorsal stripe with light yellowishwhite margins, and another resembling it on each side. The spiracles are not conspicuous.

The pupa (Fig. 146), of the usual shape of the group to which it belongs, is either dull green or brown in 
colour, and marked with dark brown on the wings and dorsal surface, the latter also bearing a few whitish dots. The skin of the caterpillar usually remains attached to the anal extremity of the pupa.

The imago (Fig. I48) has the costal margin of the fore-wings convex, and the hind-margin nearly straight; the hind-wings are rather deeply scalloped. The ground-colour of the upper surface is a dull smoky brown, with pale yellow spots, about ten on the forewings arranged as in Fig. 148, and six on the hind-wings arranged as follows: one on the costal margin, one near the centre of the wing, and four along the hind-margin. There is a white-centred, black eye-spot near the tip of the fore-wings, and four (one in each of the marginal spots) occur on the hind-wings; but the white centre is usually not present in all four. The under-surface (Fig. 149) somewhat resembles the upper, but is paler, and the markings are less distinct, except the eye-spot on the forewings, which is as distinct as that on the upper surface.

P. megæra, Linn. (Wall Butterfly, Speckled Wall Butterfly, or Gatekeeper) (Figs. I50 to 154). Why this species is called the Gatekeeper, it is hard to say. That it is speckled is certainly true; but probably many a collector will have made its acquaintance a considerable time before seeing why the name Wall Butterfly has been bestowed upon it. On one occasion I was particularly struck with the appropriateness of this title. On the top of a hill near Cheltenham one or two Megæras were disporting themselves flitting from one side to the other of an old wall, while I noticed no others round about. On visiting the same spot a day or two afterwards my friends were still haunting the same individual bit of wall. This lively little butterfly should, however, usually be sought for along sunny lanes and hedgerows, 
and it seems to have a special liking for bits of broken limestone country. It is a fairly common butterfly throughout England and Wales.

Megara is double-brooded; the eggs are laid on grass for the first brood about the end of May. The larvæ resulting therefrom are full-fed about mid-July, in which month the pupæ are to be found, and the butterflies in August. These butterflies lay eggs again, but the larvæ, after feeding for a time, hibernate, and recommence feeding in early spring; the chrysalis may be found in April, and the perfect insect is out in May.

The caterpillar (Fig. 150), which is slightly stouter in the middle, has the anal extremity bifid. The segments are transversely divided into six sections on the dorsal surface. The head and body are covered with tiny warts, each emitting a short hair. The colour is bright green, the head being of a slightly darker shade. There is generally a medio-dorsal stripe a little darker than the body-colour; below this on each side is an indistinct stripe, and below this again a pale stripe. The claspers are green, the legs almost colourless, and the tips of the anal points pink.

The pupa (Fig. 15I), which is suspended by the anal extremity, is stout. It is slightly angled, both dorsally and laterally, and there is a double series of six points on the dorsal surface. The ground-colour is bright green, the angles and points being white, tinged with yellow. The pupa is sometimes dark brown.

The imago (Figs. $15^{2}$ and 154 ) has the costal margin convex and the hind-margin of the fore-wings nearly straight. The hind-wings are slightly scalloped. The ground-colour of the upper surface is a rich orangebrown, sometimes darker in the male. All the wings 
have a brown margin, and there are two-and-a-half zigzag brown bands across the fore-wings. The base of the hind-
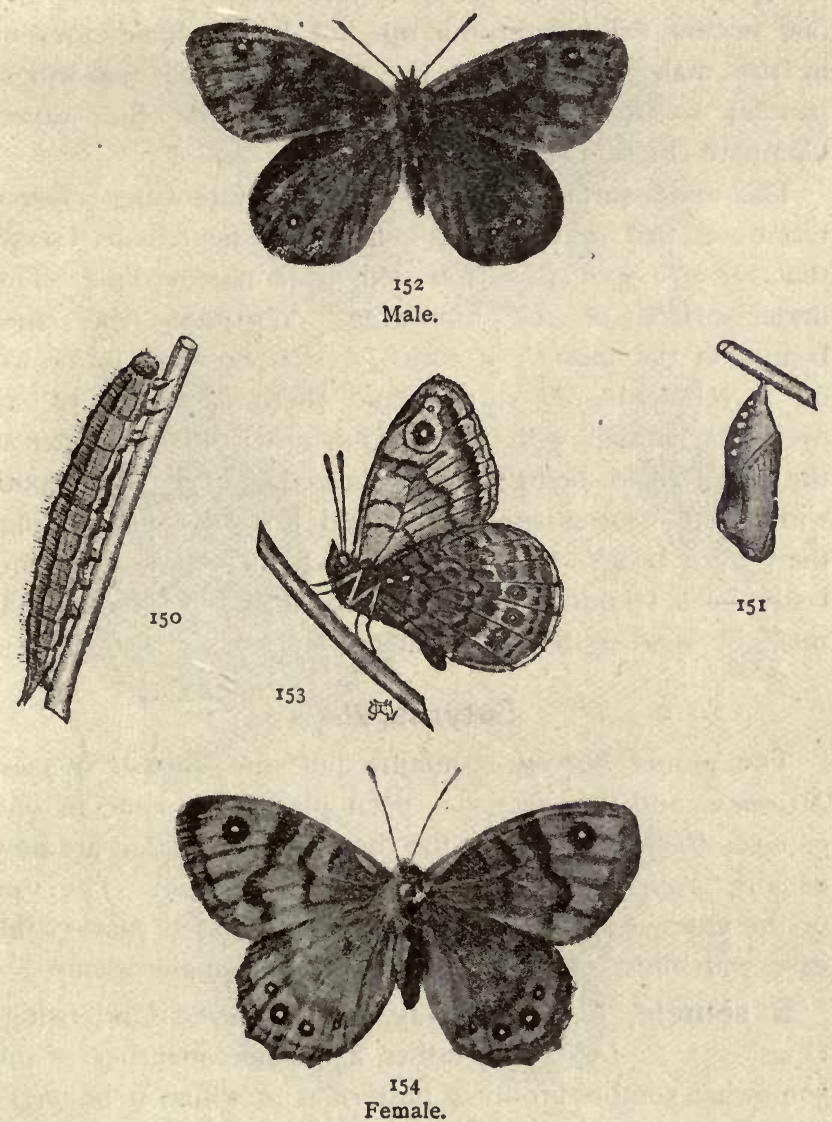

PARARGE MEGÆRA.

wings is brown, and there is a brown band outside this patch. In the light band between this and the brown 
margin are four black eye-spots, some, or all, having a white centre. Near the tip of the fore-wings there is also a large, white-centred eye-spot, and often a second tiny one occurs still nearer the tip. A brown band, present in the male only, across the centre of the fore-wings, parallel to the hind-margin, distinguishes the sexes. Compare Figs. 152 and 154 .

The under-surface (Fig. 153) of the fore-wings closely resembles that of the upper surface of the female, except that the eye-spot is surrounded by a narrow line. The under-surface of the hind-wings constitutes the chief beauty of the insect; it forms a rich network of brown on a yellowish-grey surface and there is a row of six eye-spots parallel with the hind-margin, the spot nearest the anal angle being double-centred. The black spots with white centres are surrounded first by a yellow ring, then by a brown one, then again by a yellow one, and lastly by a second brown one, producing an effect which must be seen to be appreciated.

\section{Satyrus, $B d v$.}

The genus Satyrus contains but one British species, S. semele, and this even has been placed by some in one genus-Hipparchia - with the three butterflies that are now usually grouped together in genus Epinephele. The tips of the antennæ of $S$. semele are more rounded than is the case with most of the members of the Ringlet group.

S. semele, Linn. (Grayling, or Rock-eyed Underwing) (Figs. I 55 to $15^{8}$ ), is a rather handsome member of the somewhat sombre group of butterflies to which it belongs; but its chief beauty is to be found on the under-surface. It is, moreover, the largest of the group, female specimens sometimes measuring almost 3 in. from tip to tip of the fore-wings. The Grayling's flight, jerky with frequent rests, 
closely resembles that of the Meadow Brown; but when actually flying it certainly does move somewhat faster than
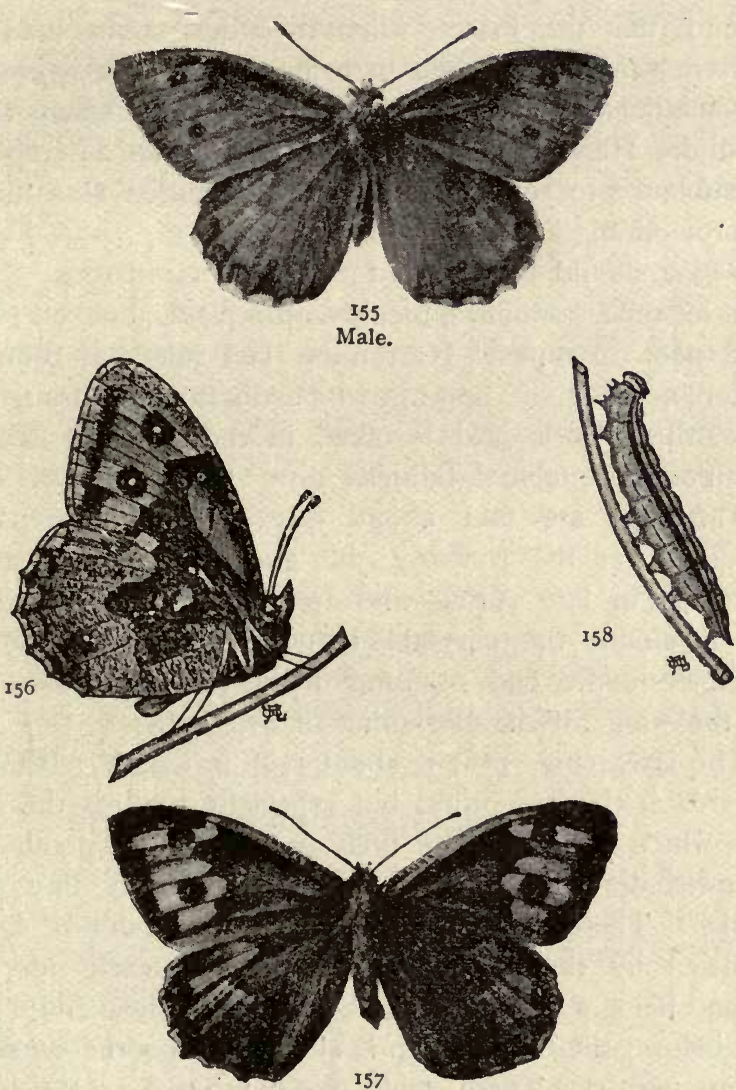

Female.

SATYRUS SEMELE.

that insect. There is, however, little difficulty in catching it, unless it should disappear from view when it rests, and 
closes its wings on a spot of bare ground. This it is continually doing, and the colour and markings of the under-surface of the wings harmonise so well with the ground, that the insect, when it settles, seems suddenly to have vanished. When bare ground or rock is absent, it sometimes rests upon the fir-tree trunks where these abound. Here we have clearly yet another instance of resemblance to some natural object acquired as a means of protection.

Semele should be looked for on heaths, in rocky spots, and in other similar uncultivated places, or on high and poor pastures. It cannot be called a common butterfly, though it appears to be distributed throughout the British Isles, and is taken in most of the English counties in suitable localities.

The eggs are laid about July. The young larvæe hibernate at the roots of the grass when quite small, re-appear in late spring, and are full-fed about June, in which month the chrysalis may be found. The imago - emerges at the end of June or in July, and continues on the wing till the beginning of September.

The larva (Fig. $15^{8}$ ) is about $1 \frac{1}{2}$ in. in length. It tapers towards both extremities, but especially towards the anal one, which is bifid. The body is practically smooth and yellowish-drab in colour, speckled with very tiny dark marks. There is an almost black medio-dorsal stripe, followed by three other dark stripes on each side, the second being widest and edged with black above and a pale tint below ; the third, which is situated below the spiracles, is very narrow. These stripes are continued on the head.

The pupa is very smooth, rounded, and swollen, and of a bright reddish-brown colour. The larva sometimes, possibly always, changes to the pupa state below the surface of the ground. 
The imago (Figs. 155 to 157 ) has the costal margin of the fore-wings convex, and the hind-margin nearly straight. The hind-wings are scalloped. The fringe of all the wings is pale, and so is the costal margin of the female. The ground-colour of the upper surface is a rather warm brown, darker along the hind-margin of all the wings. Within this margin is a lighter band, vague in the male, and distinct though not of uniform shade and width in the female. On the female, too, this light band is again bordered within by a darker shade. As in many species of this group, the male has a darker band (in this case indistinct) across the fore-wings. Both sexes have two black spots, sometimes white-centred, on the lighter part of the fore-wings. On the under-surface (Fig. 1 56 ) the fore-wings are of a yellowish tint, except the hind and costal margins, which are brown; the two eye-spots are repeated, and there is a dark patch about half-way along the costal margin. The hind-wings have a brindled arrangement of black and brown, with a very irregular light band across the entire wing, roughly parallel to the hind-margin. This species is subject to little variation except in size.

\section{Epinephele, Hïb.}

The genus Epinephele contains three species: E. ianira, $E$. tithonus, and $E$. hyperanthes, all, the first especially, being common, but sombre, sunmer butterflies, with a weak, uncertain flight.

E. ianira, Linn. (Meadow Brown) (Figs. $\mathrm{r}_{59}$ to $\mathrm{r}_{3}$ ), is the particularly common brown butterfly that in the summer months confronts us at every turn, and, I fear, too often meets with the contempt due to familiarity, which is the fate of most common things ; and certainly its quaker garb of simple though harmonious browns does not tend to 
revive an interest which its plentifulness has destroyed. The collector will nevertheless need to take a large number of specimens, and that for two reasons. In the first place the wings are very fragile, and a small amount of wear usually makes them ragged and the insect unfit for the cabinet. Again, the male differs considerably from the female, and both are subject to a good deal of variation, especially in the depth of the ground-colour.

The Meadow Brown has a very weak, fluttering style of flight, so that it would be the easiest thing in the world to catch it were it not for its habit of settling every few moments. In this it is wise, for no sooner are its wings closed than it seems to disappear, so closely does the under-surface of the wings resemble in colour the bare ground or the ripening grass of the summer fields.

The eggs are laid on grass in July or a short time before or after, and hatch in a little under a fortnight. It is not long, however, before the young larvæ retire to the roots of the grass to hibernate. They re-appear in May, and are full-fed at the beginning of June, early in which month the chrysalides may be found. The perfect insects begin to appear in the second half of June, and are on the wing till August.

The larva (Fig. 160), which is about $1 \frac{1}{4}$ in. in length, has a large head, and a forked tail tinged with pink. There is a slight lateral skin-fold, with an edge lighter than the ground-colour, which is bright green, somewhat lighter on the dorsal surface and darker on the ventral. There is a medio-dorsal dark stripe, as well as slight traces of subdorsal ones. The segments are not clearly marked, nor are the sections into which they are divided. The body is covered with short white hairs.

The pupa (Fig. 159) is stout and but little angled; the anterior extremity is slightly two-eared. The ground- 
colour is pale yellowish-green, touched in places with whitish-yellow. The markings, which vary in intensity,
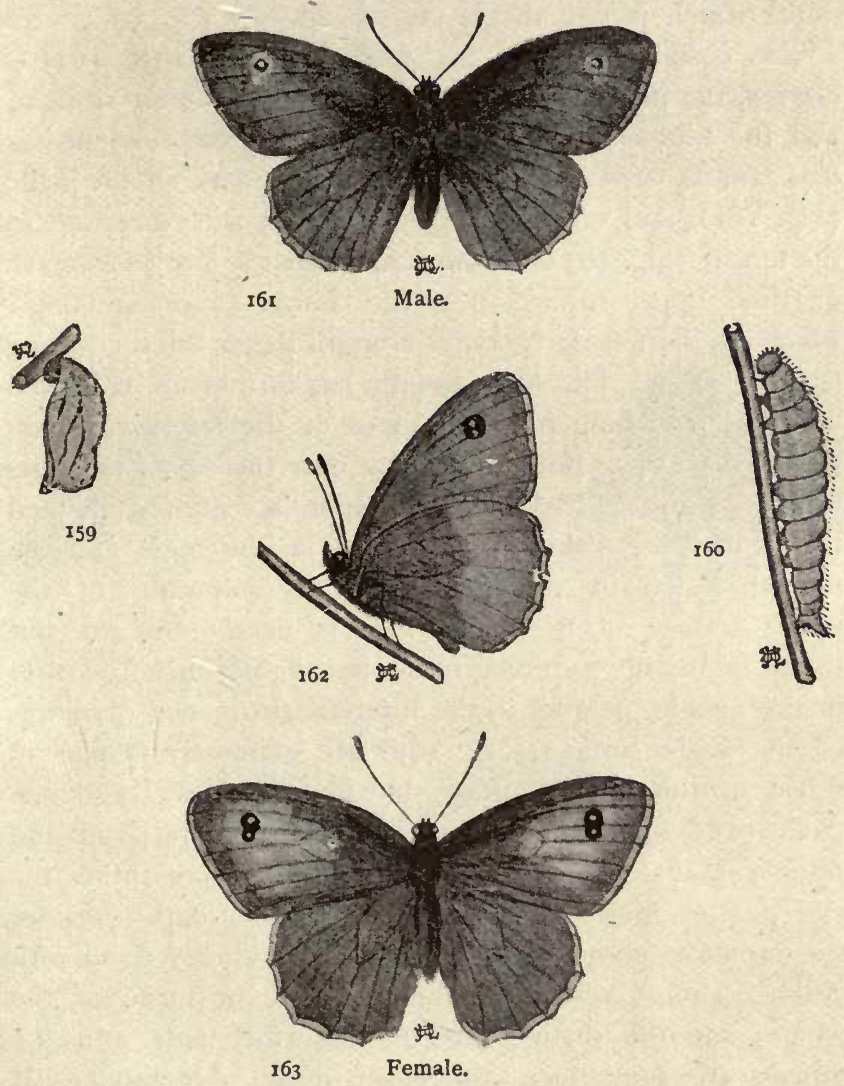

EPINEPHELE IANIRA.

are brown, and consist of two dorsal and one or two lateral lines of spots, sometimes united, three longitudinal 
streaks on the wing-cases, and a few dots on the cases of the antennæ and tongue. The skin sometimes, perhaps always, remains attached to the anal extremity of the pupa, which is not always suspended.

The costal margin of the imago (Figs. 161 to 163 ) is convex, the hind-margin of the fore-wings is nearly straight, and the hind-wings are scalloped. The ground-colour is a dark, smoky brown, sometimes extremely dark in the male (Fig. 16I), and often varying in the opposite direction in the female (Fig. 163). In the former sex the fore-wings have on their upper surface, near the centre, an orange tinge, which in the female becomes a bright patch, often covering half the wing. The male usually has further an ill-defined dark bar stretching from the base of the fore-wings halfway to their tip. Both sexes bear near the tip of the forewings a white-centred black eye-spot, sometimes inclined to be double, within a pale ring in the male and the orange patch in the female. The colouring of the upper surface of the hind-wings is nearly uniform, but there is usually a broad somewhat lighter band, clearer in the female, parallel to the hind-margin. The markings of the under-surface (Fig. I62) are extremely similar to those of the upper surface but much lighter, and the paler band on the hind-wings is more conspicuous, and often contains two or three black spots, representing the eye-spots on most of the butterflies of this group. Besides the variations mentioned, specimens sometimes occur with patches almost white in colour on one or more of the wings; and the distinctions between the male and the female are sometimes almost or quite obliterated. It will thus be clear, as was mentioned above, that a long series will be required for the cabinet, and though each individual may be of little worth in itself, yet a good series may be very valuable indeed. 
E. tithonus, Linn. (Large Heath, Gatekeeper, or Small Meadow Brown) (Figs. I64 to 167).-The first English title is usually employed, for $P$. megcera is sometimes called
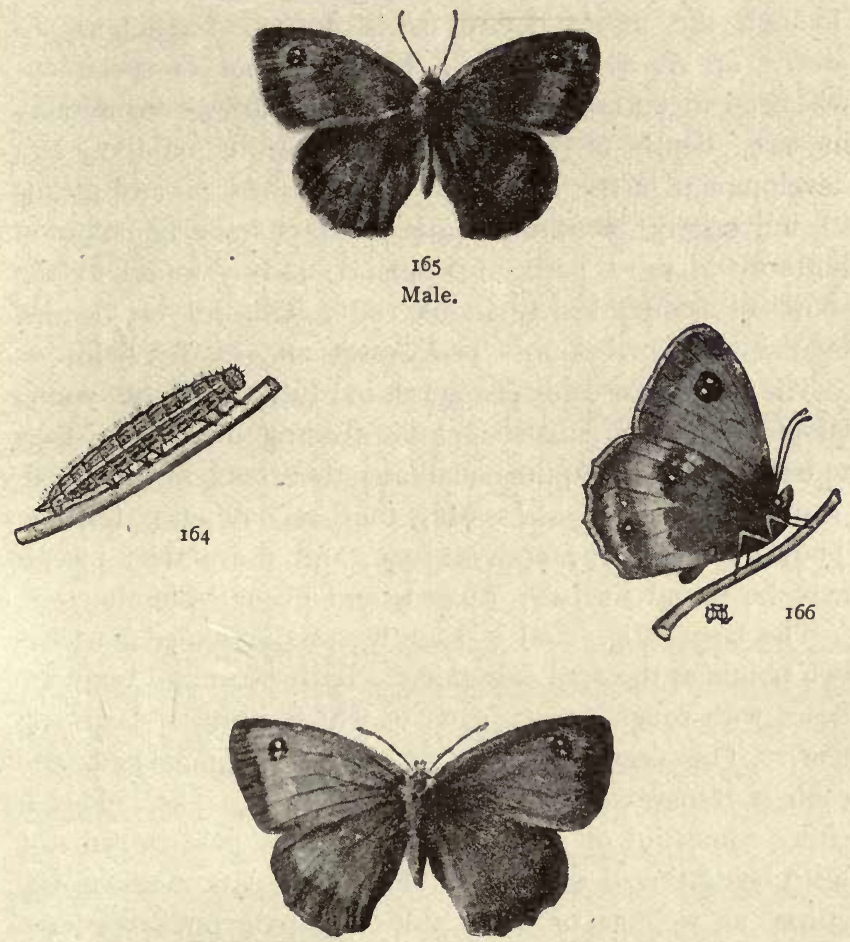

167

Female.

EPINEPHELE TITHONUS.

the Gatekeeper, and the term Small Meadow Brown is too likely to cause confusion between this butterfly and its congener ianira. E. tithomus falls an easy prey to the 
collector's net, for its flight is particularly weak. It should, however, be noticed that it has a special liking for brambleblossoms, and a careless stroke at a butterfly on such a perch usually results in an unsightly rent in the net. Though the insect before us is not so fragile as $E$. ianira or $E$. hyperanthes, a large number of specimens will need to be taken, for like them it varies considerably in size, depth of colouring, and in the number and development of the eye-spots. Though not by any means so universally plentiful as ianira it is a fairly common butterfly in most parts of England, and is found in the south of Scotland. It should be sought for on heaths, by the sides of brambly hedgerows, and in dry fields.

The eggs are laid on grass in July, and the young larvæ appear in August. After feeding for a time they retire, while still quite small, to the roots of the foodplant to hibernate. In May they recommence feeding. They pupate at the end of June, and the perfect insects may be found in July, August, and even September.

The larva (Fig. 164) is slightly spindle-shaped and has two points at the anal extremity. Both head and body are beset with rough points, each of which emits a short, stiff hair. The segments may be clearly distinguished, and each is transversely divided into sections. The colour is either some tint of green usually dull, or pale brown, the head being tinged with pink. There is a dark medio-dorsal stripe, as well as on each side two pale ones bordered above with a darker tint.

The stout pupa, less than $\frac{1}{2}$ in. in length, is pale drab in colour, considerably marked with brown.

The imago (Figs. 165 to 167 ) has the costal margin of the fore-wings convex, the hind-margin of the fore-wings nearly straight, and the hind-margin of the hind-wings scalloped. The ground-colour of the upper surface is a 
rich sienna-brown, usually darker in the male. The wings are broadly bordered with brown, of which there is also a patch at the base of the hind-wings. In the male a band of the same colour stretches nearly across the forewings almost parallel to the hind-margin. Near the tip of the fore-wings is a black eye-spot with two white eyes, and sometimes between this spot and the inner margin may be seen one or two black spots, evidently an indication of the more numerous eye-spots in some other butterflies of this group. There is usually a small white-centred eye-spot near the anal angle of the hindwings, and occasionally one or two black spots as on the fore-wings. Specimens taken with these extra spots should of course be preserved. On the undersurface (Fig. 166) the colouring of the fore-wings closely resembles that of the upper surface. On the hind-wings, the base and the centre of the hind-margin are brown; the rest of the wing is greyish-brown, containing about five rather indistinct brown eye-spots with white eyes.

E. hyperanthes, Linn. (Ringlet, or Wood Ringlet) (Figs. I68 to I7 I), is a dark butterfly, about equal in size to ianira, and often seen flying with it. It is not, however, found everywhere, like ianira, though it is common, and widely distributed. It may be obtained in the southern part of Scotland and in Ireland, as well as locally throughout England. E. hyperanthes haunts woods and shady hedge-rows. It may be easily caught, for its flight is very weak, but specimens for the cabinet should be taken as soon as possible after they have left the chrysalis, for scarcely any butterfly so quickly loses its freshness as the one before us. Owing to the great variation in the eye-spots, a rather long series will be required.

The eggs are laid singly in July and August on various species of grass. The young larva grows but 
little before hibernating. It recommences feeding in early spring, and is full-fed at the beginning of June. The chrysalis may be found during the same month, and the imago is out during July and August.

The larva (Fig. 168), which is of the form common to this group of butterflies, is very pale brown in colour. There is a medio-dorsal darker brown stripe, and the rest of the dorsal surface is marked irregularly with the same colour. The head, which is rough and hairy, bears three faint brown stripes on each side. The skin-fold above the legs and claspers is nearly white and edged with hairs; the spiracles are black. The segments are distinctly divided into sections.

The pupa (Fig. I69), which is suspended by the anal extremity, has much the same ground-colour as the larva -pale brown. The cases of the wings and antennæ are nicely marked with darker brown, and the dorsal surface is ornamented with spots, both large and small, of the same colour.

The imago (Figs. I 70 and I I I) has the costal margin convex, and the hind-margin of the fore-wings slightly so; the hind-wings are scalloped, but not so distinctly as in ianira. The ground-colour of the upper surface is an extremely uniform dark blackish-brown; that of the undersurface is brown also, but of a lighter and warmer tinge; the fringe is white. The only adornment is a series of beautiful eye-spots, parallel to the hind-margin of the wings, and most conspicuous on the under-surface (Fig. I I I). They are black, with white centres, and surrounded with a very pale yellow ring. The usual number is two on the forewings, and five on the hind ones; but some or all may be indistinct or absent. A third may often be found below the other two on the fore-wings, and the second one, reckoning from the costal margin on the hind-wings, 
may have a small one attached to it below. On the upper surface the eye-spots are generally inconspicuous (often invisible, especially in the male), the yellow bordering being usually faint, and the white centre absent from most of the spots.

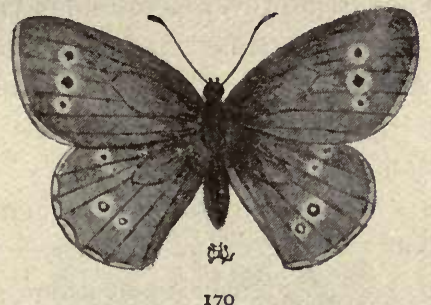

Female.

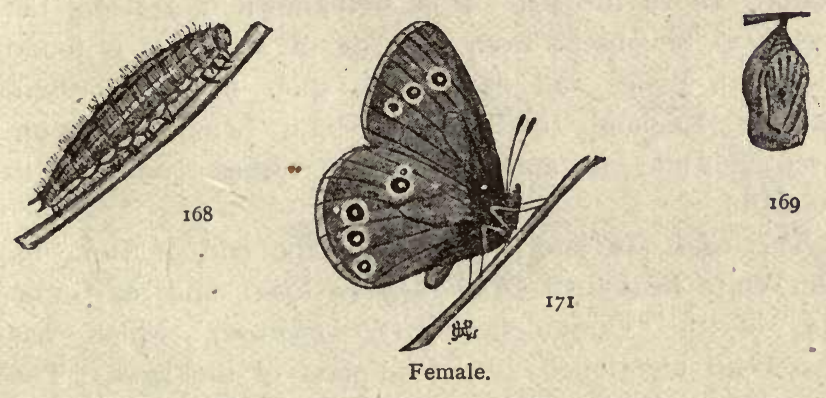

EPINEPHELE HYPERANTHES

Cœnonympha, Hüb.; Chortobius, Guenée.

Cononympha, the last genus of the Ringlet group, is represented in Britain by two species, $C$. typhon and C. pamphilus, which are probably the least conspicuous for beauty among the small company of our butterflies, though the former sometimes rises from this mediocrity when it chances to appear with well-developed eye-spots 
on the under-surface of the wings. This species is, indeed, subject to great variation, while the other, pamphilus, is particularly constant.

C. typhon, Rott.; C. davus, Fabr. (Figs. 172 to 175 ), in common parlance usually gocs by the name of the Marsh Ringlet; it is, however, sometimes called the Small Ringlet, but as this name has also been by some bestowed on $E$. epiphron, it would probably be well if it were dropped for both, especially as $C$. pamphilus deserves the name better than either.

C. typhon is a northern butterfly, frequenting "mosses" or swampy spots on moors and heaths. In Scotland it is often found at considerable elevations, one authority mentioning its occurrence at a height of more than $2000 \mathrm{ft}$, above the sea. It is well-known in Ireland, but seems to be absent from the Isle of Man. It is found in North Wales and in suitable spots in the northern half of England (its southern limit being Burton-onTrent), while it appears to be rather common in Scotland.

The eggs are laid singly about the end of June, on the White Beak-rush (Rhynchospora alba), and maybe on one of the Cotton-grasses (Eriophorum), which has also been mentioned as a food-plant of the larva. The caterpillars come out in about a fortnight and, after feeding for a month or so, hibernate till the next spring. They are full-fed at the end of May, and in the next month the chrysalis may be found. The imago is on the wing from early in June till the end of July, and sometimes in August and September.

The larva (Fig. 173) has been described as having a wide head covered with tiny warts, and the body tapering somewhat to the bifid tail. The surface is nearly smooth, and the colour brightish green, the body being striped 
but not the head. There is a medio-dorsal bluish-green stripe, bordered on each side by a narrow yellow one. There are also two lateral yellow stripes, one above and the other below the spiracles. The stripe above the spiracles is bordered on each side with dark green. The legs and claspers, as well as the ventral surface, are dark green.
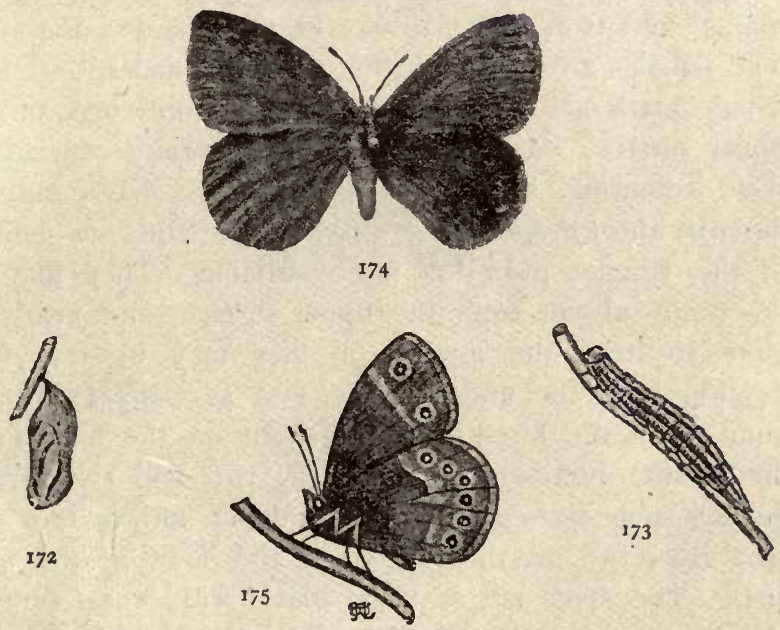

CENONYMPHA TYPHON.

According to Newman, the chrysalis (Fig. 172), which is suspended from the edge of a leaf of the food-plant, is just slightly angled and keeled. The colour is principally bright green, speckled with a whitish-green. The wing-cases are brownish, with a couple of longitudinal darker marks.

All the wings of the imago (Figs. I74 and I75) are rounded, and the costal margin of the fore-wings is slightly 
convex. The fringe is white. The ground-colour is pale drab-brown, somewhat brighter than elsewhere in the central part of the fore-wings. On the under-surface (Fig. 175) the wings are still lighter, the hind-wings and the margins of the fore-wings being ash-coloured. On this surface, too, there is a whitish line backed with a darker tint across the fore-wings, and on the hind-wings an irregular one of the same colour starting from the costal margin and stretching half-way or more across the wing. The females are usually lighter than the males, and have a pale mark across the middle of the fore-wings on the upper surface. So far, individuals are pretty constant in their colouring and markings, but we have still to describe the eye-spots, and in these perhaps no member of the Ringlet group is more variable. They may be practically absent from the upper surface, and nearly or quite so from the lower; or they may be very fully developed on the under-surface, and as many as four in number on the fore-wings and seven on the hind ones, though the numbers are generally two and six. When the eye-spots show at all on the upper surface they are, as a rule, two on the fore-wings and four on the hind ones. The spots are as usual black, with white centres, and surrounded by a pale ring. The variety with the welldeveloped eye-spots, whose home seems to be in the north of England, is sometimes called philoxenus, Esper, or rothliebi, Staudinger.

C. pamphilus, Linn. (Figs. 176 to 179 ), is usually, in non-scientific language, called the Small Heath, though it has another name, not, however, a good one-Least Meadow Brown. It is a small butterfly, particularly common and very constant in its colour and markings. It no doubt prefers heaths, downs, commons, and similar situations, but is by no means limited to them; indeed, it 
wculd be hardly possible to have a day with the net and not meet with a Small Heath. But though our little friend is common, and particularly sober-tinted, it has one very great merit, it appears early in the spring, and lingers, with the Small Copper for a companion, till quite late in the autumn, when the majority of the butterfly tribe are either dead or laid-up for their winter sleep.

No localities need be given for so ubiquitous a butterfly as the Small Heath; it is found throughout the
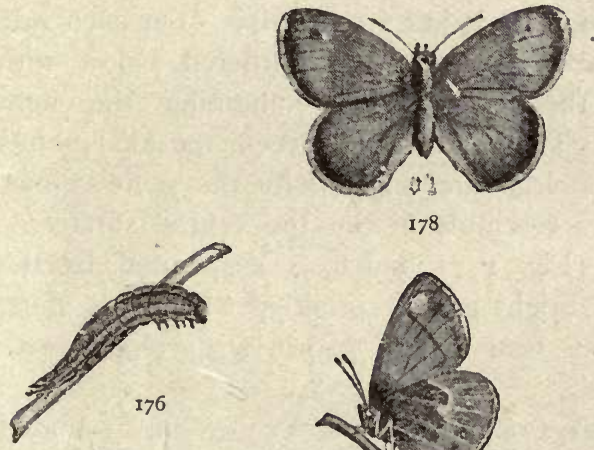

178
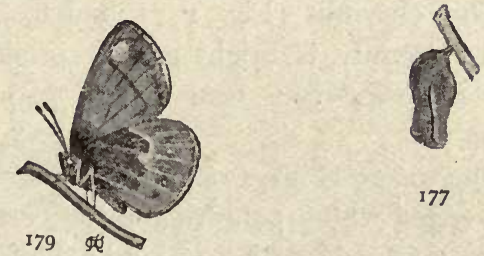

177

CEENONYMPHA PAMPHILUS.

British Isles, the Scotch specimens being finer than those produced farther south. Its flight is extremely weak, and the veriest novice with the net could scarcely find much difficulty in procuring specimens; but it has the habit, common to many of the Ringlet tribe, of suddenly stopping in its flight, when, on closing its wings, it often seems to disappear as if by magic, in which case its pursuer would scarcely stay to search for it, but would look out for the next comer. 
The eggs are laid on several species of grass in May and June. The larvæ hatch out in about a fortnight and are full-fed in a month-that is to say, usually towards the end of July. The imago would thus appear in August. The earlier brood must no doubt have passed the winter in the larval state.

The larva (Fig. 176) decreases in girth towards the anal extremity, which is bifid. Ois the back, each segment is divided into transverse sections, which are sprinkled with tiny points. The body is bright green, with a palebordered, medio-dorsal, darker green stripe. On each side is a pair of dark green stripes, bordered below with yellowish-green, the lower stripe containing the light brown spiracles. The head is dull green, the anal points are pink, and the legs are tinged with the same colour, while the claspers resemble in tint the ventral surface.

The chrysalis (Fig. 177), which is suspended by the anal extremity, is bright green, sprinkled with white dots, and the wing-cases bear a dark brown stripe edged with white.

The imago (Figs. 178 and 179 ) has all the wings rounded and edged with a pale fringe; the costal margin of the forewings is convex. The ground-colour of the upper surface (Fig. 178) is a pale drab-brown, similar to that of the last butterfly, its congener; but the wings in the butterfly before us have darker brown margins. Near the tip of the forewings is a black spot, often indistinct, within a ring slightly paler than the ground-colour. The under-surface (Fig. 179) of the fore-wings closely resembles the upper; but the black spot has a white centre, and is situated in a bright yellow ring, while a dark line stretches from the costal margin a good way across the wing nearer the base. The hindwings are ashen-grey, dark near the base, and paler near the hind-margin. Between these two colours is an 
irregular white mark, stretching from the costal margin half-way across the wing. Outside this is a row of about four tiny white spots, each within an inconspicuous brown patch.

The Small Heath is not subject to much variation, and the male does not materially differ from the female.

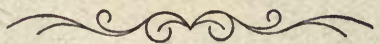




\section{CHAPTER IV. \\ LYC ENID E.}

\section{Thecla, Fabr. (The Hairstreaks).}

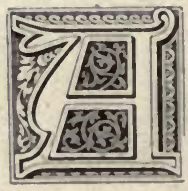

DISTINCT group of five small or middlesized butterflies comprises the genus Thecla -T. betula, T. $W$-album, T. pruni, $T$. quercus, and $T$. rubi. In shape, the perfect insects bear a considerable resemblance to one another. All the species have, near the anal angle of the hind-wings, a more or less developed tail, though not pronounced in the case of $T$. rubi, and all except the same butterfly are marked on the under-surface with whitish streaks, whence the genus obtains its English name. Both sexes of the imago possess six perfect legs adapted for walking. The larvæ are all onisciform (or woodlouse-shaped); the head can be entirely withdrawn into the second segment, and the body is so much spread out at the sides that the legs and claspers are quite concealed. The stout, rounded pupa is, normally, attached by the tail, and girt. The food-plant is some bush or forest tree, to whose twigs the eggs are attached in the autumn, there to remain intact till the following spring, 
except in the case of rubi which passes the winter at the pupal stage.

T. betulæ, Linn. (Brown Hairstreak, or Thecla of the Birch) (Figs. 180 to 184 ), is the largest of the genus, sometimes expanding more than $1 \frac{1}{2}$ in. from tip to tip of the fore-wings. Although the specific name is derived
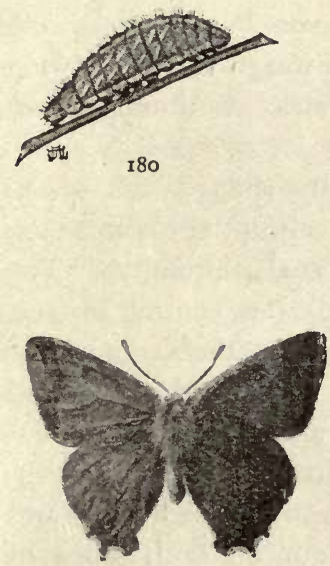

182

Male.

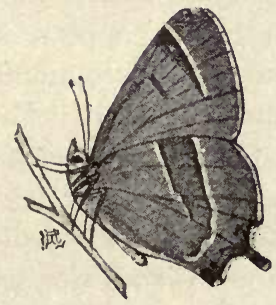

184

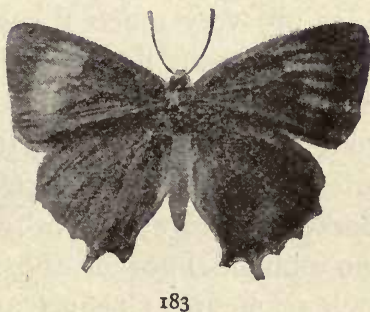

Female.

THECLA BETULÆ.

from the Birch (Betula alba), the Sloe (Prunus spinosa) is as often as not selected as the food-plant, and on that the caterpillar may be fed in captivity. While the Brown Hairstreak has a liking for oak-woods, it also frequently leaves them, giving the collector a sight of its charms as it flits along some country hedgerow, enticing him forward in pursuit. Though there are many localities 
in suitable situations up and down England where this butterfly may be taken, yet it is well worth capturing, for it can seldom be described as common. It is present in Ireland, but does not appear to be found in Scotland.

The eggs are laid in the autumn-in September or even October-and are firmly attached to the twigs of the food-plant. They remain unbroken till the spring, when the young larvæ appear, and feed in May and June, at the end of which month or beginning of the next the pupæ may be found. The imago is on the wing from July till September, sometimes continuing even into October.

The larva (Fig. 180) is woodlouse-shaped, the dorsal surface being arched and sloping abruptly towards the head, but gradually towards the anal extremity. The sides are very much dilated towards the ventral surface, and the brown head is retractile within the second segment. The segments are deeply and clearly separated from one another. The dilatation and dorsal ridge bear pale, stiff hairs. The ground-colour is bright green, marked with two whitish-yellow lines on each side and two oblique lines of the same colour on both sides of each segment. One pair of lines is dorsal, and the other pair runs along the dilatation below the yellowish-white spiracles. The ventral surface, legs, and claspers are greenish. The caterpillar, from which this description was made, a day or so before turning became pale ashenpurple in ground-colour while the markings became quite white.

The pupa (Fig. I8I), which sometimes at least is unsuspended and has the last skin attached to the anal extremity, is short, unangled, and dark brown in colour. The wing-cases and anterior extremity are freckled with 
paler brown, and the spiracles are of the same tint, which also appears at the divisions between the abdominal segments.

The imago (Figs. 182 to 184 ) has the costal margin nearly straight, the hind-margin of the fore-wings simple and not far from straight, while that of the hind-wings is scalloped; the fringe is white. The hind-wings bear a square projection at the anal angle, and a slightly-curved tail at the extremity of the next nervure. The groundcolour of the upper surface is a deep sepia-brown, with a short black streak, which also shows on the undersurface, across the discoidal cell of the fore-wings. Outside this is a small patch paler than the ground-colour, which in the female (Fig. 183 ) becomes a broad, curved orange bar, stretching nearly across the fore-wings, and in the same sex some traces of it are also to be found on the hind-wings. The tail and projection are reddish-brown (more distinct in the female), edged with black inside the white fringe. The under-surface (Fig. 184) has a ground-colour of rich greyish orange-brown, not however of uniform tint. On the fore-wings is a darker brown bar parallel to the hind-margin, decreasing in width as it recedes from the costal margin. It has a dark outer edge succeeded by a white line; this bordering is also repeated less distinctly on the inner edge of the streak. On the hind-wings is a broader irregular band similar in direction and colouring to that on the fore-wings. Within the fringe on the hind-wings is a blackish line, and within this again a red band with three black spots, two being on the anai projection. The legs and ventral surface of the body are white.

T. W-album, Knoch (White-letter Hairstreak, sometimes called Black Hairstreak) (Figs. I85 to 187 ) is not one of our common butterflies, though it is less scarce 
than formerly, and has in places occurred profuselynotably, near Ripley, in 1827 . Like many another butterfly, it has a liking for bramble-blossoms, and may there be sought, though it often soars aloft over the elm-trees on which, maybe, its youth was passed.

Though possibly not a Scotch or Irish butterfly, it is fairly well distributed in England, having been taken in the following counties at least: York, Derby, Nottingham, Stafford, Shropshire, Lincoln, Warwick, Northampton, Suffolk, Cambridge, Hereford, Huntingdon, Buckingham, Gloucester, Worcester, Dorset, Somerset, Berks, Hampshire, Surrey, Sussex, Oxon., Middlesex, Kent, Wilts., Essex, and Glamorgan.

The eggs are laid in late summer or autumn on the bark of one of our two native elm-trees, the Wych Elm (Ulmus montana) and the Common $\operatorname{Elm}$ (U. campestris). They hatch in the spring, and the caterpillars may be beaten from the above trees in May and June. The imago appears in June, and is on the wing till August.

The larva (Fig. I85) is shaped like the rest of its genus, the black, shining head being retractile within the second segment. Fine hairs are to be found over the whole of the body, which is bright green in colour, the ridges on the back being yellowish. Each segment bears on each side two pale yellowish oblique lines. The divisions between the segments are distinct.

Such in substance is Newman's description in "British Butterflies," but in The Entomologist - for 1873, the same authority describes the larva as dingy-brown dorsally, approaching to red-brown on the sides, and to green in the interspaces of the segments. The ventral area is also greenish. On each side of each segment are two oblique and very ill-defined stripes of a paler shade. Legs and claspers are pale dingy-green. Buckler 
gives two figures, practically agreeing in detail with the two descriptions respectively.

In the same article in The Entomologist the pupa is described as obese and moth-like without angles; the head rounded and the anal segment incurved and invisible from above. The thorax and abdomen are hairy. The colour of the dorsal or hairy area is reddish-

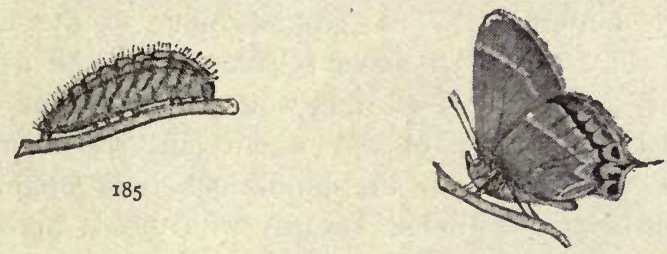

187

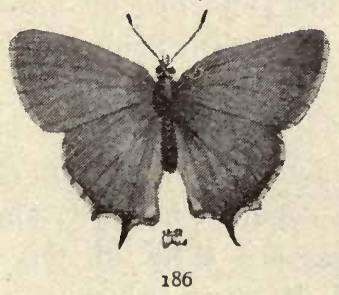

THECLA W-ALBUM.

brown, with a rather broad, medio-dorsal stripe commencing behind the thorax and extending to the anal segment. On each side of the dorsal surface of each segment is an oblique whitish mark. The colour of the ventral or smooth portion of the pupa is olive-green at first, but gradually becomes darker and almost black.

The costal margin of the imago (Figs. 186 and 187 ) is nearly straight, the hind-margin is rounded, being very slightly convex. The hind-wings are somewhat scalloped, 
the anal angle bearing a roundish projection, the nervure next to it a long black tail, and the next one again a short one; the fringe is pale. The ground-colour of the upper surface is a deep sepia-brown, and the projection at the anal angle bears a small orange-red spot. It should be noticed that pruni has a series of orange semilunar spots on the hind-wings, otherwise there is a considerable resemblance between the upper surfaces of the two butterflies. The ground-colour of the undersurface (Fig. 187) of $W$-album is pale brown with a white irregular streak across all the wings, that on the hindwings taking the form of a $\mathrm{W}$, whence the specific name. Outside this streak on the hind-wings is a bright red band of arches bordered inwards with black, and then with a slender white line. Outside the orange band is a series of black spots and one blue one; next follows a slender white line, and then a black one just inside the fringe.

T. pruni, Linn. (Dark Hairstreak or Thecla of the Sloe, sometimes called the Black Hairstreak) (Figs. 188 to 190), is by no means a common butterfly, and was, when first discovered in England, early in the present century, confused with $T$. $W$-album, which it somewhat closely resembles, and for which, therefore, it is still liable to be mistaken.

T. pruni is found neither in Ireland nor in Scotland, and in but few counties in England and Wales, these being Berks, Bucks, Hants, Derby, Huntingdon, Monmouth, Northampton, and Suffolk. In some localities in these, however, it is occasionally plentiful.

The eggs are laid in the autumn on twigs of the Sloe (Prunus spinosa); they hatch in the spring, the larva being found in May and June, the pupa in the latter month, while the imago appears in June and July. 
The larva (Fig. 188) is of the shape common to the genus, the head, which is brown on the crown and black at the mouth, is retractile within the second segment. There is a shallow, longitudinal fissure down the back, and the segments are distinctly marked. The two ridges on the back, the collar round the second segment, and the dilatations below the spiracles, are fringed with hairs. The colour is pale green. There

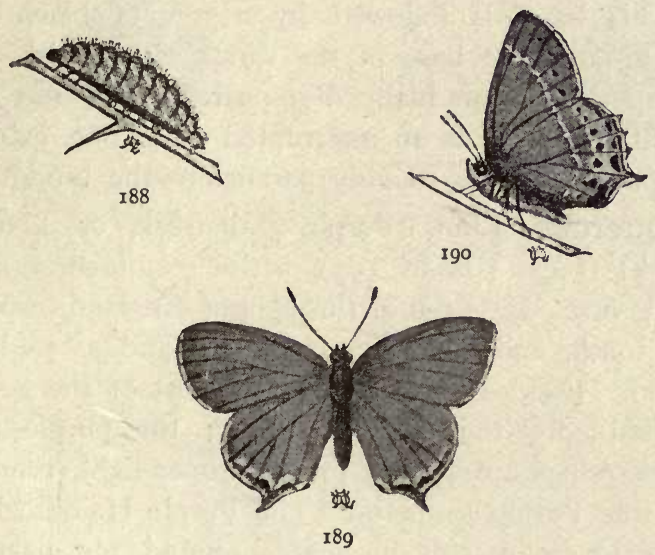

THECLA PRUNI.

are oblique yellow lines on the segments, and the spiracular region bears a yellow stripe.

The costal margin of the fore-wings of the imago (Figs. 189 and 190) is nearly straight and the hindmargin rounded. The hind-margin of the hind-wings is slightly scalloped, the last nervure but one being continued into a rather long tail. The border of the wings is black and the fringe whitish. The upper surface (Fig. 189) is dark brown, with two or three semilunar 
orange-red spots near the anal angle of the hind-wings and a tiny blue one at the very corner. The undersurface (Fig. 190) is a light and brighter brown. Within the black border is a fine, light line on the hind-wings, and within this on the same wings is a row of semicircular black spots, largest near the anal angle, where they are adorned with blue. Within these again is a band of orange-red extending to the fore-wings, where it decreases in width, and disappearing before reaching the tip. This band is followed by a row of black spots, edged towards the base of the wings with bluish-white; these spots also gradually disappear on the fore-wings. Within these again is an interrupted white line, extending across all the wings roughly parallel to the hind-margin.

T. quercus, Linn. (Purple Hairstreak, or Thecla of the Oak) (Figs. I9I to 193), is the commonest species of the genus. It is found throughout England, especially in the south, and is well known in Ireland, as well as in Scotland. Besides being the commonest of the genus, it is undoubtedly the most beautiful; the purple sheen, when its wings are viewed in the proper light, reminding one of the Purple Emperor. The Purple Hairstreak, too, delights to frolic with its mates around the oaks (and sometimes limes and ashes) in its woodland haunts. It usually keeps well out of the way of the net among the higher branches of the trees, but occasionally descends within reach of its expectant foe.

In July the eggs are laid on the Oak (Quercus Robur); they hatch in the following spring, and the larvæ are full-fed in June, at the end of which month the chrysalides may be found. The imago comes out in July and continues into August.

The larva (Fig. 19I), which is of the usual onisciform shape, has a retractile head and distinct divisions between 
the segments. The back is grooved, the sides are dilated, and the whole body is covered with tiny hairs. The colour is brown, the dorsal surface being lighter and having a central dark line edged with yellow. The seven central segments have a light streak with dark edging below. The dilatation below the dark brown spiracles is yellowish.
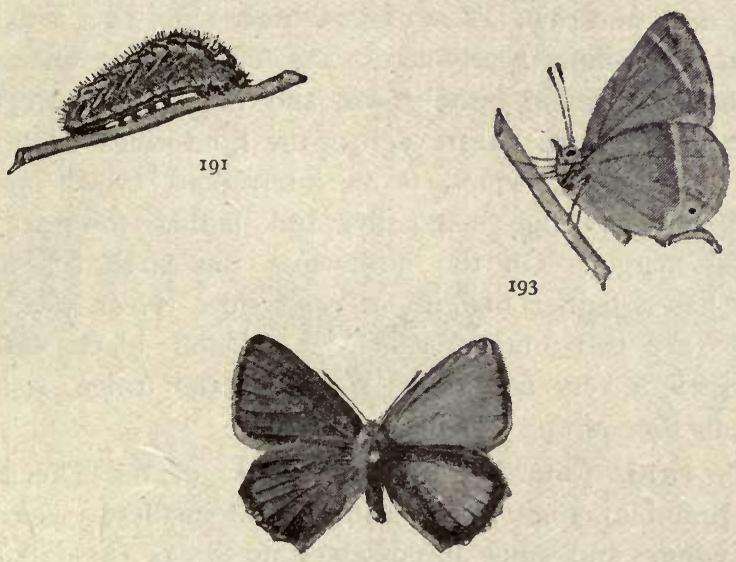

192

Male.

THECLA QUERCUS.

The stout, rounded, reddish-brown pupa is normally suspended from an oak-leaf by the anal extremity, and girt; but it is sometimes found beneath the surface of the ground. The dorsal surface is darker than the rest, and freckled with still darker brown, and the dark marks on the sides of the larva are reproduced in the pupa, which is covered with very tiny hairs.

The perfect insect (Figs. 192 and 193) has the costal 
and hind margins of the fore-wings nearly straight and the hind-wings slightly scalloped. These latter bear at the anal angle a blunt protuberance, and at the end of the nervure next to it a short tail. The fringe is white; the upper surface (Fig. 192) is deep sepia-brown, with a slight purple blush suffusing the whole of the male. In - the female the purple is confined to one part only of the fore-wings, near the base and inner margin, but there it is very deep and rich. The under-surface (Fig. 193) is ashen grey. Stretching nearly across the fore-wings is a straight white line backed with brown, and there is an irregular one of the same nature across the hind-wings. Outside this, on the fore-wings, is an interrupted brown streak, with a light edge externally, and fading towards the costal margin. On the hind-wings this streak is paler and has a lighter margin on each side. Near the anal angle are two orange spots, one being black-centred. There is a very fine dark line inside the fringe, and an equally fine white one inside that.

T. rubi, Linn. (Green Hairstreak, or the Thecla of the Bramble) (Figs. 194 to 196), is the smallest species of the genus, and since it possesses no streak (but a series of dots) on the under-surface, and has a very slightlydeveloped tail, might easily on first thought be left out of the present genus. It is fairly well distributed throughout England, and is not uncommon in Scotland.

The caterpillar feeds on the buds and leaves of the Bramble (Rubus fruticosus), on the Broom (Cytisus scoparius), and on Dyer's Weed (Genista tinctoria). T. $r u b i$ is on the wing in May and June, the larva is found in June and July, and the winter is passed in the pupal stage.

Like the rest of the genus the larva (Fig. 194) is woodlouse-shaped and has a small retractile head. The body 
is green, and has a dorsal dark green stripe with paler centre, and a yellow lateral stripe. The yellow streaks on the dorsal protuberances are edged with dark green below. The short hairs give a soft appearance to the larva.

The pupal stage is assumed just below the surface of the ground, the stout dark brown chrysalis being covered, except on the wing-cases, with short dark hairs.

The costal margin of the fore-wings of the imago (Figs. 195 and 196$)$ is nearly straight, as also is the hind-margin. The hind-wings are scalloped, and bear at the anal angle a blunt projection. The tail is only slightly developed;
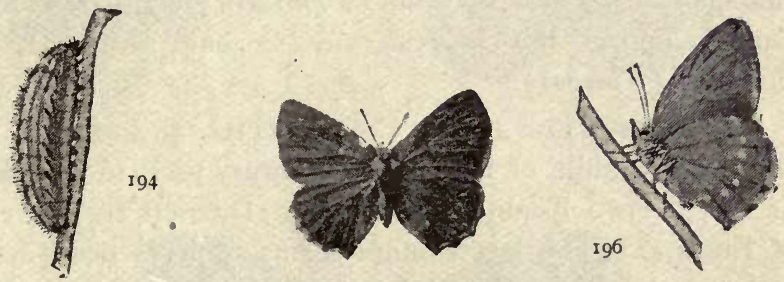

195

THECLA RUBI.

the fringe is pale. The colour of the upper surface is a rich, dark brown, with a small red spot on the anal projection. The dark nervures show up rather clearly. On the under-surface (Fig. 596) the ground-colour is a rich emerald-green, with the inner edge of the fringe of all the wings and the costal margin of the fore-wings brownish. There is also a rather broad brown band along the inner margin of the fore-wings. A line of white dots crosses all the wings; but they may be nearly absent, especially from the fore-wings. There is a dark spot on the anal projection. 


\section{Polyommatus, $B d v$. (The Coppers).}

Members of the genus Polyommatus may easily be distinguished by the refulgent metallic coppery tint of the upper surface of their wings. A tendency, rather conspicuous in $P$. phlocas, to develop a tail on the hind-wings shows the close relationship of this genus to the Hairstreaks, Thecla. Since it seems now hopeless to expect the Large Copper ( $P$. dispar) to turn up again, the above-named $P$. phlacas is the sole representative left to us of this beautiful genus. $P$. virgaurea, Linn. (Golden Copper), though not a native, is an occasional visitor anongst us, as also may be $P$. rutilus, Wer. (Continental Large Copper), the nearest ally to our extinct Large Copper ( $P$. dispar).

P. dispar, Haw. (Large Copper) (Figs. 97 to I 99), till about the middle of the present century used to be taken in one or two localities in the Fen Distriçts in the east of England. The last capture seens to have been made in 1847 or 1848 . Reports of its occurrence since have more than once appeared, but no capture has been authenticated, and it is to be feared that the Iarge Copper is now absolutely extinct. This is the more to be regretted, as the species is not absolutely identical with any Continental species. $L$. dispar was, in fact, an insect exclusively British. Such being the case, the number of specimens is necessarily limited, and the fortunate possessors are able to realise a high price for them. On the r6th May, 1892, as recorded in The Entomologist, p. 142, seven specimens were sold, and fetched in the aggregate $\mathcal{L}_{5}$ r 8 s. 6 d., or on the average $£^{2} 5$ s. $6 \mathrm{~d}$. each. One female sold for $£ 4$ ros.; while a male, without either antennæ or abdomen, realised $£ \mathrm{I}$ 8s., a poor female $£ \mathrm{I}$, and a chipped male, showing the under-surface, $\mathcal{E}_{\mathrm{r}}$ ros. The 
home of the Large Copper used to be at Whittlesea Mere, in Cambridgeshire, and at Yaxley and Holm Fens, in Huntingdonshire, while it has been taken at Benacre, in Suffolk, and at Bardolph Fen, in Norfolk. The drainage of the Fens has no doubt a good deal to do with its

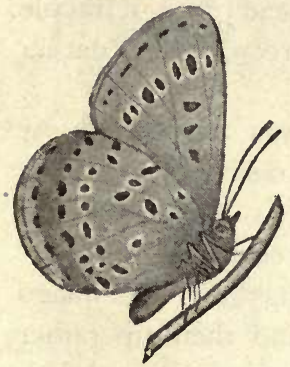

197

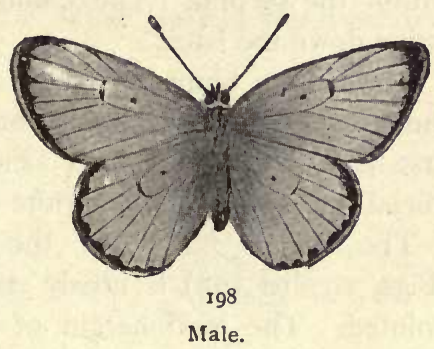

Male.

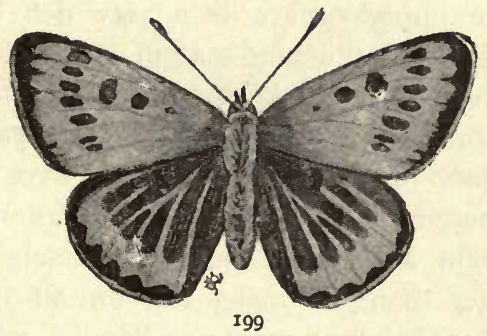

Female.

POLYOMMATUS DISPAR.

extinction; but it may be due more to the large numbers taken by collectors, the discovery of the larva, and the burning of the herbage of the reclaimed Fens.

The eggs appear to have been laid in August, on the leaves of the Great Water-dock (Rumex Hydrolapathum). 
The young larvæ soon retired for the winter, passing that period in continual danger from the floods. They were full-fed in June, the chrysalides could be found in July, and the imagines were out till August.

The larva had a convex dorsal surface and a flat ventral one hiding the legs and claspers. The segments were clearly divided, and the tiny head was retractile within the second. The colour was green, with a darker stripe down the back.

The stout, blunt chrysalis, which was suspended by the anal extremity, and girt, has been described as being first pale green and then ashen, and as having a black dorsal line, and two short white ones on each side.

The costal margin of the fore-wings of the imago (Figs. 197 to 199) is nearly straight, and their tip rather pointed. The hind-margin of the fore-wings is rounded, and of the hind-wings a little undulating. The groundcolour of the upper surface is a very rich copper. In the male (Fig. 198) the hind-margin of the fore-wings is black, and there is a black streak half-way between the margin and the base, while between this again and the base is a black dot. The hind-wings have a notched black hind-margin and a black streak half-way between the hind-margin and the base. The female (Fig. 199), which is larger than the male, has on all the wings a similar but broader hind-margin. Parallel with this, on the fore-wings, is a row of seven black spots, and in the discoidal cell are three of the same colour, decreasing in size towards the base of the wing. On each hind-wing there is a copper band within the black hind-margin, and the rest of the wing, except the nervures, is either black or densely sprinkled with black scales. The ground-colour of the under-surface (Fig. 197) is, on the fore-wings, light orange-red, with a bluish-grey hind- 
margin. There are numerous black spots, many of which have a whitish circumference. The ground-colour of the hind-wings is bluish-grey, with an orange-red hindmargin. Here again are many black spots, all possessing a pale circumference. The Large Copper was not subject to much variation.

P. phlœas, Linn. (Small or Common Copper, or, as Gilbert White calls it, the Snall Golden Black-spotted
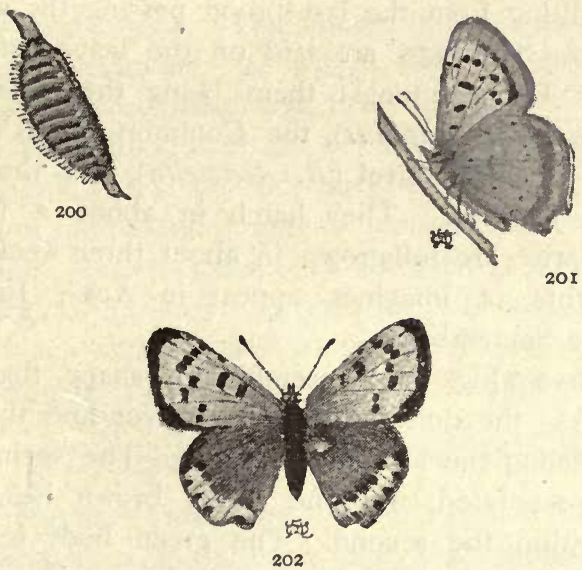

POLYOMMATUS PHLEAS

Butterfly) (Figs. 200 to 202), at any rate appears little likely to become extinct. It is a delightful little creature, for besides being remarkably rich in colouring, it is early on the wing, and, not content with displaying its beauties in the summer, braves the rain and storms of early autumn, before which most butterflies disappear. The apprentice in the collector's craft will hail it with delight, for not only is its flight weak, but if only . 
the eye can follow the little gem as it alternately opens and closes its wings, any number of strokes of the net may be taken without the insect displaying much concern.

No localities need be given for a butterfly which is common everywhere and in many diverse situations; it seems, however, to prefer heaths and other open, uncultivated spots.

The Small Copper appears to be three-brooded, the larvæ resulting from the last brood passing the winter in that stage. The eggs are laid on the leaves of various species of Dock, amongst them being the Broad-leaved Dock (Rumex obtusifolius), the Common Sorrel ( $R$. Ace. tosa), the Sheep's Sorrel ( $R$. Acetosella), and the Fiddle. dock ( $R$. pulcher). They hatch in about a fortnight, and the larvæ are full-grown in about three weeks. The three flights of imagines appear in April, June, and August or September.

The larva (Fig. 200) resembles in shape that of the Hairstreaks: the dorsal surface is convex and the ventral flat, concealing the legs and claspers. The segments are distinctly separated, and the small, brown head is retractile within the second. The green body is covered dorsally with very tiny flesh-coloured dots, each emitting a brown bristle, and sometimes bears a faint brownish medio-dorsal line.

The stout, blunt chrysalis is suspended by the anal extremity, and girt. Except the anterior ventral part, the surface is covered with very short, flesh-coloured hairs. The colour is pale whitish-brown, sprinkled with numerous darker brown markings, which arrange themselves so as to form seven series, one being medio-dorsal and six lateral. The antenna-, leg-, and wing-cases are also adorned with - dark markings. 
The costal margin of the fore-wings of the imago (Figs. 20r and 202) is nearly straight; the hind-margin of the fore-wings is nearly straight also and entire, that of the hind-wings is a little waved, the anal angle having a slight protuberance, and the nervure next it bearing an indication of a tail. The upper surface of the fore-wings (Fig. 202) is bright copper-red, with a broad black hind-margin and about ten black spots. The hind-wings have a notched black band on the hind-margin, within which is a copper band, and the rest of the wing is very dark, with indications of black spots. The under-surface (Fig. 20r) of the fore-wings resembles the upper, but the ground-colour has no metallic lustre, and the hind-margin is reddishgrey. The ground-colour of the hind-wings is also reddish-grey, with an indistinct coppery band parallel with the hind-margin, and a considerable number of small, dark brown spots. This butterfly is subject to a good deal of variation, in both the size and distinctness of the black spots as well as in the ground-colour, which is occasionally silvery-white instead of copper.

\section{Lycæna, Treitschke (The Blues).}

In the genus Lycana we have ten very beautiful butterflies, though in most cases they are somewhat small: $L$. batica, $L$. agon, $L$. astrarche, $L$. icarus, $L$. bellargus, $L$. corydon, $L$. argiolus, $L$. semiargus, $L$. minima, and $L$. arion; while by some, L. argiades, Pall. (the Shorttailed Blue), which has been a few times taken, is claimed as an eleventh. The blue colour, which though various in shade is often very intense, is usually only present to any great extent in the males; the females are generally brown with but a sprinkling of blue scales, and those chiefly at the base of the wings. One species, L. astrarche, has not a particle of blue in either sex, while the female 
of $L$. argiolus has that colour almost as well developed as the male.

The larvæ are. all what is called onisciform-that is, woodlouse-shaped-the head being small and retractile within the second segment, which is somewhat flattened, as are also the eleventh, twelfth, and thirteenth; while the segments between have each a pair of prominences, forming two ridges along the back with a slight hollow between them. The sides are dilated below the spiracles, and the ventral surface is flat, hiding the legs and claspers.

The pupæ are rather slender and practically without points or angles. Normally they are attached by the anal extremity, and girt; but the larva often turns without attaching itself at all, and at times even below the surface of the ground. Several species are almost, or quite, confined to chalk districts; but others are less fastidious in that respect.

A beginner will doubtless find this genus one of the most confusing of those into which our butterflies are divided, as many of the species bear a very close resemblance to one another; and especially is this the case with a few of the females, those of $L$. icarus, $L$. bellargus, and $L$. corydon sometimes almost defying separation. The following table may perhaps be found of use for purposes of identification :

\section{Synopsis of Species of the Genus LyCAna.}

A. a. Hind-wings tailed; under-surface streaked,

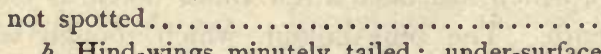

b. Hind-wings minutely tailed; under-surface silvery-white, with tiny black spots....... argiades.

B. Possessing marginal red spots, and a white dash on the under-surface of the hind-wings:

a. Having no spots between the discoidal spot and the base of the wing- 
I. Metallic spots near hind-margin of hindwings, white dash obsolete ......... agon.

2. Metallic spots absent; no blue scales. on either male or female ........... astrarche.

b. Having about three black spots near the base of the hind-wings ; females very similar-

I. Fringe white............... icarus.

2. Fringe dark at the nervures, the sprinkling of blue scales on the upper surface of females of the same tint as the blue of the corresponding males-

i. Male intense sky-blue ...........

ii. Male pale silvery blue...........

bellargus. -corydon.

C. Without red spots or white dash :

$a$. Upper surface cold sky-blue ...........

b. Upper surface dark purple-blue, female brown

c. Very small, brown, male sprinkled with silvery-blue.......................

$d$. Large, brown suffused with blue, a band of black spots near the middle of the upper surface of all the wings .................

argiolus.

semiargus.

minima.

arion.

L. bætica, Linn. (Long-tailed Blue, or Pea-pod Argus) (Figs. 203 and 204), though now usually included in the list of British butterflies, has been taken on but few occasions in this country, and is probably but a straggler amongst us. It was first captured, I believe, in England, in 1859, a season in which it was abundant in France, and was taken in the Channel Islands. L. batica is widely distributed, being common in South-eastern and South-central Europe. The tails, together with the streaky appearance of the under-surface of the wings and the arrangement of the blue colouring of the upper surface, cause this butterfly to have much the look of a Thecla. As will be seen from the following list of captures recorded in The Entomologist, few specimens have been captured in England: 1859, Brighton; 1878, Freshwater, 
Isle of Wight; I880, Aldwick, near Bognor; I882, Bournemouth; 1886 or 1887 , Heswall, Cheshire.

L. batica is on the wing at the end of the summer and in the autumn, and the eggs lie dormant during the winter. In England the larvæ might feed perhaps inside the pods of the field pea and other leguminous plants.

The larva, of the usual Lycena shape, varies through brownish, brownish-green, to bright green. There is a dark medio-dorsal stripe, as well as a white lateral one

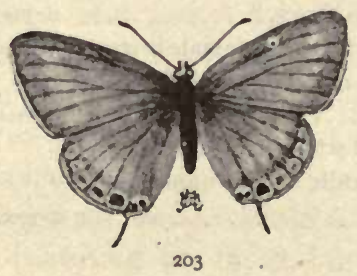

Female.

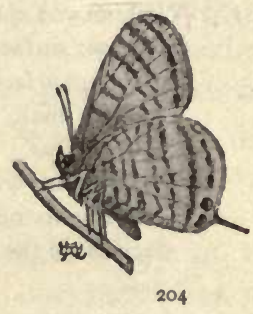

LYCENA BETICA.

below the yellow spiracles. The sides bear oblique lines, dark above and paler below.

The pupa is yellowish or reddish, with brown dots, which are especially numerous on the head. The spiracles are black, and there is a dark line extending along the posterior part of the front of the pupa. It is suspended from the food-plant, and girt.

The imago (Figs. 203 and 204) has the costal and hind-margins of the fore-wings slightly convex ; the hindwings bear a long tail at the extremity of the nervure next the anal angle. The colour of the upper surface (Fig. 203) is dull brown shot with blue, that colour being more 
concentrated in the female. Parallel to the hind-margin of the hind-wings is a row of pale-edged spots, the two nearest the anal angle being much brighter than the rest, the last but one especially so. These are more strongly developed in the female, which sex has also a line of whitish spots parallel to these. The under-surface (Fig. 204) is pale drab, thickly streaked with a darker tint and with a whitish band parallel to the hind-margin of all the wings, and about a third of the way in. There are near the anal angle of the hind-wings two large black spots edged on the outer side with metallic-green.

L. argiades, Pall. (Short-tailed Blue), though possibly a native of England, has been recorded no more than five times: two in 1874 , two miles from Frome; and three in 1885 , a female, August 18 th, at Bloxworth Heath, Dorset, a male, August 20 th, at the same place, and another specimen on August 2 Ist near Bournemouth. It may be that others have been taken and wrongly classified, as this butterfly closely resembles both agon and icarus on the upper surface. The food-plant is the Narrow-leaved Bird's-foot Trefoil (Lotus major). Argiades should be sought for from May till August. There may be as many as three broods in a season, the spring brood producing the largest specimens.

The costal margin of the male imago is convex, and the hind-margin of all the wings entire, except for a minute tail near the anal angle of the hind-wings. Inside the white fringe is a narrow, dark line. The undersurface is pale silvery-blue, with black dots, and in general appearance somewhat closely resembles the undersurface of $L$. argiolus.

L. ægon, Schiff. (Silver-studded Blue) (Figs. 205 to 208), though one of the smallest of our Blues, is, as far as the male is concerned, one of the handsomest. It should 
be sought for on heaths, downs, and commons, and in such situations seems to be fairly well distributed throughout England. It is by no means confined to chalk, the sandy downs of Surrey, indeed, being amongst its favourite haunts.

The eggs are laid in the summer on the Bird's-foot (Ornithopus perpusillus), and hatch in the following spring. The larvæ, which have also been seen feeding on the common Furze (Ulex europceus), are full-fed about the middle or end of June, when the pupx may be found. The butterflies appear the next month and continue into August.

The colour of the larva (Fig. 205), which is of the shape common to the genus, is bright yellowish-green. Along the back is a dark stripe with whitish edges; near the head this line assumes the form of three spots, and behind these it bears four white dots. On each side is a subdorsal yellowish line bordered by rather dark green ones. There is a whitish line on the lateral dilatation, and above it a series of indistinct oblique yellowish streaks. The twelfth segment bears two rather conspicuous warts, and the body is covered with fine, short hairs. Its length is not much over $\frac{1}{2}$ in.

The pupa, which is less than $\frac{1}{2}$ in. in length, has the larval skin attached to the anal extremity, and does not seem to be very well adapted for suspension. It is unangled and smooth, but not shining. The abdomen is swollen, and the wing-cases are long and prominent. It is dull green in colour, with a line of dark marks shaped like arrow-heads down the back.

The wings of the imago (Figs. 206 to 208) are long and slender, and the margins are entire, those of the fore-wings being slightly convex. The fringe is white. The colour of the upper surface of the male (Fig. 207) 
is deep blue, with a rather broad black band inside the fringe. The upper surface of the female (Fig. 208) is dark sepia-brown, sometimes tinged with blue, and with a more or less developed line of spots fringed with red along the hind-margins. If the blue tinge is absent, the female very closely resembles $L$. astrarche on the upper surface. The under-surface (Fig. 206) is bluish-grey in the male, brownish-grey in the female. In each case there is a band of red

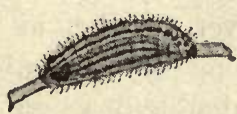

205

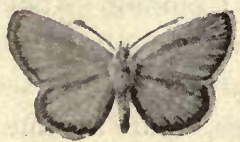

207

Male.

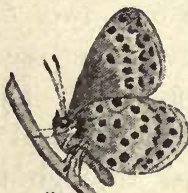

次

206

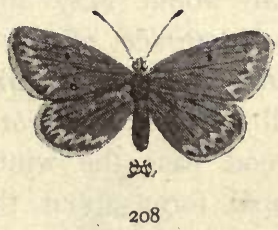

Female.

LYCANA EGON.

spots parallel to the hind-margin of all the wings. There is a line of black spots outside the red and of black arches beyond it. Each fore-wing contains besides seven white-margined black spots, and each hind-wing about a dozen such spots. Some, or all of the black spots forming the series near the hind-margin of the hindwings have a bright silvery-green metallic centre, whence the common name. 
L. astrarche, Bergsträsser, medon, Esper, agestis, Hübner, idas, Haw. (Brown Argus) (Figs. 209 to $2 \mathrm{II}$ ), although belonging to the family of Blues, has not a particle of blue about it. This inconspicuous little butterfly is well distributed, and usually plentiful in England and the southern half of Scotland; but so greatly does it vary with change of latitude that many have been the discussions and controversies amongst naturalists as to whether the different forms should constitute one, two, or even three species. The weight of the evidence seems, however, to be in favour of considering them all to belong to one, though the southern and typical form is double-brooded, while the others pass through the cycle of changes but once in a season.

The eggs of the typical form are laid twice in the year, about May and August, in small groups on the under-surface of the leaves of the Common Rock-rose (Helianthemum vulgare), and also on the Hemlock Stork'sbill (Erodium cicutarium). The larvæ of the second brood pass the winter in that stage, and assume the pupal form about the end of April. The imagines of the typical form appear in May and again in August; but those of the northern forms do not appear till the end of June.

The larva (Fig. 209) is about $\frac{1}{2}$ in. in length and of the form common to the genus. The colour is pale green with a medio-dorsal brownish-purple stripe, and on each side very faint pale oblique stripes, which, in the northern form at least, disappear when the larva is nearly full-grown. There is also a lateral pink stripe on each side, edged with darker pink above and still darker below. The pale, inconspicuous spiracles are situated in the uppermost pink stripe. The dorsal 
projections and lateral dilatations bear white hairs. The ventral surface is green, with white hairs, the claspers are yellowish, and the legs are marked with black. Mr. Buckler thought that in the typical form the green was

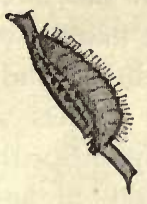

209

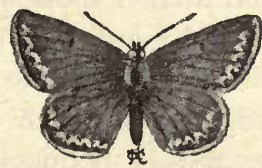

210

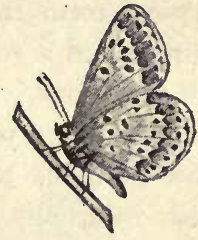

2 I

LYCENA ASTRARCHE.

more lively and full than in the Scotch form, and the pink along the lateral region darker, inclining to purple.

The chrysalis is not much over $\frac{1}{3}$ in. in length. That of the northern form has been described as being rather

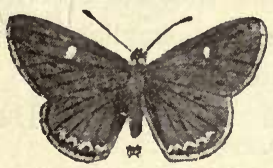

212

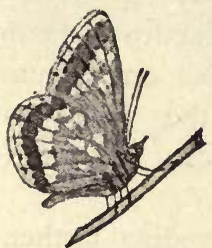

213

LYCENA ASTRARCHE, VAR, ARTAXERXES.

thick, smooth, but not shining. The colour is bluishgreen except the abdomen, which is dull yellowish. On each side is a white-centred pink stripe, and a black curved streak is found on each side of the head. The larval skin remains attached to the anal extremity. 
The costal margin of the fore-wings of the imago (Figs. 210 and $21 \mathrm{I}$ ) is straight, and the hind-margin of both fore- and hind-wings rounded and entire. The fringe is white, slightly marked with brown at the nervures. The colour of the upper surface is dark sepia-brown. In the typical form there is a black discoidal spot on the forewings, and a row of red arched spots inside the margin of all the wings. On the under-surface (Fig. 2 I I) the groundcolour is greyish-brown. Inside the margin comes a row of black spots, edged with white externally and with red internally. The red is bounded by black arches edged with white towards the base of the wing. Within this marginal black, red, and white band there are on the fore-wings about seven white-edged black spots, and on the hind-wings about a dozen. The white dash on the hind-wings is conspicuous. This, the typical form, is seen at its best on the downs in the south of England.

As we proceed northwards, the black discoidal spot on the fore-wings becomes surrounded with white, the red spots grow less and less distinct, and gradually disappear from the fore-wings, while the black centres to the spots on the under-surface become smaller. At this stage the little butterfly acquires the varietal name salmacis, Steph. (Castle Eden Argus, or Durham Argus).

Proceeding farther north and crossing the Border into Scotland, the red marks will be found to have quite disappeared from the upper surface of the fore-wings, and almost from the hind ones; the discoidal spot on the fore-wings is now pure white, and the under-surface extremely delicate, for the black centres have altogether disappeared from the white spots. We now have var. artaxerxes, Fabr. (Scotch Brown Argus) (Figs. 2 I 2 and 2 I 3 ). 
L. icarus, Rott., L. alexis, Hüb. (Common Blue) (Figs. 214 to 218 ), is the brilliant little butterfly that is so familiar to us throughout the summer, and joins the Small Copper and Small Heath in many a sportive gambol in the sunshine. It is found everywhere throughout the British Isles, and nearly everywhere is very common.
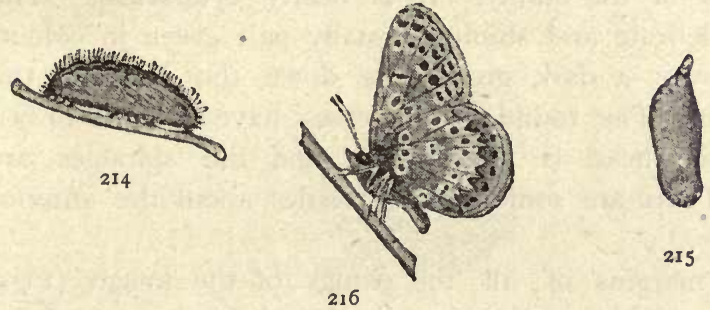

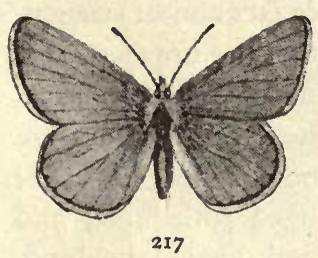

Male.

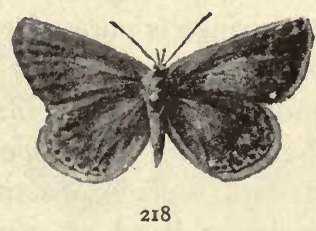

Female.

LYCENA ICARUS.

The eggs are laid on the Bird's-foot Trefoil (Lotus corniculatus), and on Ononis arvensis and no doubt O. spinosa, the two Common Rest-harrows. There are more broods than one during the season, and the winter appears usually to be passed in the larval stage. The butterflies are on the wing from May to October.

The larva (Fig. 214), which is a little over $\frac{1}{2} \mathrm{in}$. in length, is covered with tiny hairs. It is dark green in 
colour, but paler on the dorsal ridges. The dilatations below the spiracles are yellowish, the spiracles themselves being pale green. The small, black, and shining head is hidden beneath the second segment. There are three pale, oblique, lateral lines on each side of each segment.

The pupa (Fig. 215), about $\frac{1}{2}$ in. in length, is perhaps seldom suspended and girt, as is normally the case with members of the family. It is nearly cylindrical. The skin is delicate and shining, usually pale green in colour, and having a dark green line down the back of the abdomen. The rounded wing-cases have a slight brown tinge; the head is pale brown, and the spiracles are light. There are some minute bristles about the anterior extremity.

The margins of all the wings of the imago (Figs. 2 I 6 to 218 ) are entire, the costal and hind ones of the fore-wings being very slightly convex-in fact almost straight. The fringe is pure white. The colour of the upper surface of the male (Fig. 217) is brilliant blue of a purple tinge, and a very narrow black line separates this colour from the fringe. The upper surface of the female (Fig. 218) is dark sepia-brown more or-less tinged with blue, and having a band of spots edged with red inside the hindmargin of all the wings. The under-surface (Fig. 2 I6) is grey, bluish in the male, browner in the female. There is the band of red spots near the hind-margin, having a row of black spots outside them and a row of black arches behind. The fore-wing bears beside nine whiteedged black spots, and the hind-wing about a dozen of a similar nature. The white dash is well developed. The females vary considerably in the amount of blue and in the development of the red spots on the upper surface, and a good series will be required for the cabinet. 
L. bellargus, Rott., L. adonis, Fabr. (Adonis Blue, Clifden Blue, or Dartford Blue) (Figs. 219 to $22 \mathrm{r}$ ). - The brilliant sky-blue of the upper surface of the male of this species far surpasses in purity and intensity the blue of any other member of the genus. It is a south of England butterfly, and is there almost entirely confined to the chalk. It has been taken in Bucks, Lancashire,

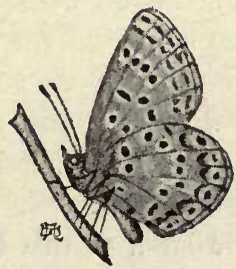

219

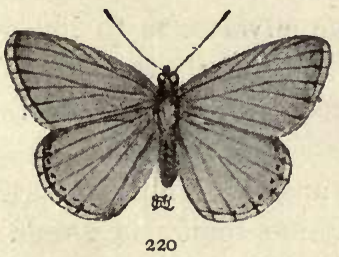

Male.

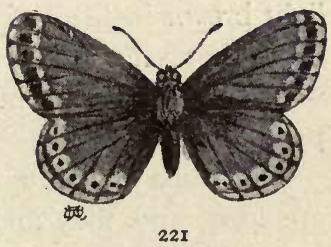

Female.

LYCAENA BELLARGUS.

Somerset, Gloucestershire, Devon, Dorset, Hants and the Isle of Wight, Sussex, Surrey, Kent, and Argyll.

The eggs are laid on the Horseshoe-vetch (Hippocrepis comosa) twice in the year, the insect being double-brooded. The first flight of butterflies takes place about the end of May or beginning of June, and the second about the middle of August. The larvæ resulting from the second 
brood are full-fed in the spring, and produce the earlier flight of butterflies.

The larva, which, when fully grown, is about $\frac{5}{8} \mathrm{in}$. in length, is of the usual Lycana shape, with a double series of dorsal humps on segments three to ten. The colour is deep green. The dorsal humps all bear a yellow dash, and the succession of dashes forms on each side an interrupted dorsal yellow line, while a line of the same colour near the edge of the lateral dilatation surrounds the caterpillar, except near the anterior extremity. There is besides a row of yellow dashes below the spiracular dilatation and above the feet. The spiracles are black, and the head is very nearly so. There is, according to Mr. W. Buckler, very little difference between the larva of this butterfly, $L$. bellargus, and that of $L$. corydon except that in the latter the ground-colour is a yellower green, and the hairs are light brown instead of black. The larvæ seem to like to bury themselves just below the surface of the ground, where they form a rudimentary cocoon before taking the pupa state.

The pupa is without points or angles. The wing-cases are long, and they and the thorax are somewhat shining, but the abdomen has a roughened appearance; the surface is slightly hairy. At first the wing-cases are greenish, while the rest of the body is of a browner green; afterwards the whole body takes on a brownishyellow tinge.

The costal and hind margins of the fore-wings of the imago (Figs. 219 to $22 \mathrm{I}$ ) are slightly convex. All the wings are entire, and the fringe is white, with dark marks at the nervures. The upper surface of the male (Fig. 220) is bright sky-blue, with a fine black line separating that colour from the fringe. Close to this line on the hind- 
wings is a small black dot between each pair of nervures. The upper surface of the female (Fig. 22I) is a dull, smoky brown, with a sprinkling of sky-blue scales near the base of the wings. There is a small, dark, discoidal spot on the fore-wings, and a marginal row of red spots with black centres and black circumferences on the hindwings : the red spots, though present, are very indistinct on the fore-wings. The under-surface (Fig. 219) is pale brown, with the marginal row of red spots as on the upper surface. Besides these there are about nine whiteedged black spots on each fore-wing and about a dozen on each hind-wing. The hind-wings also bear a white discoidal spot and the characteristic white dash.

L. corydon, Fabr. (Chalk-hill Blue) (Figs. 222 to 227), after $L$. arion is one of the largest of our Blues. The male also is one of the handsomest, the blue of its wings reminding one of the silvery moonlight on a clear, frosty night. It is a chalk-loving insect, and though not entirely confined to that kind of country, must usually there be sought. Its chief home is in the south of England, where in some districts it is plentiful. Roughly speaking, it has been found in most of the counties south of a line joining the Wash to the Bristol Channel, as well as in Glamorganshire, Lancashire, Cumberland, Westmoreland, and Lincolnshire.

The eggs are laid on several plants of the order Leguminosa, such as the Kidney Vetch (Anthyllis vulneraria), Bird's-foot Trefoil (Lotus corniculatus), and Clover, or Trefoil (Trifolium). The larvæ are full-fed about the middle of June or earlier, and the butterflies are on the wing in June, or even before, and continue into July and August.

The larva (Figs. 222 and 223) very closely resembles that of $L$. bellargus, the only difference, as mentioned 
before, consisting in the yellower green ground-colour of $L$. corydon, and the light brown hairs of the same larva instead of the black ones of $L$. bellargus.

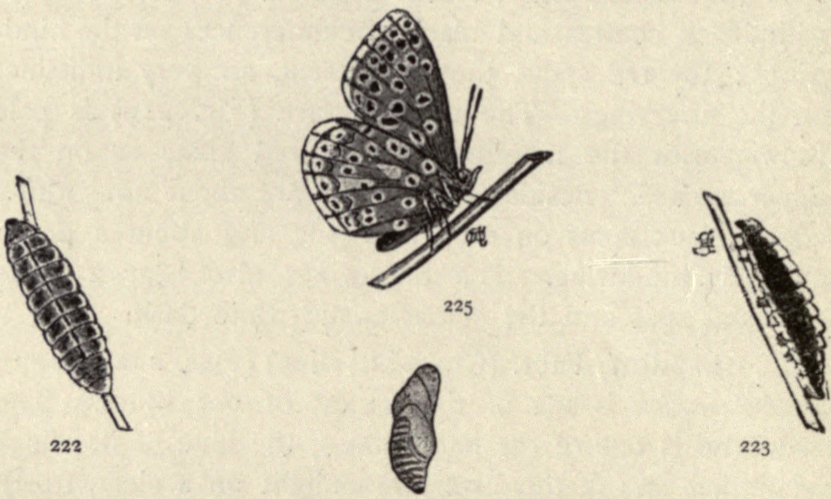

224

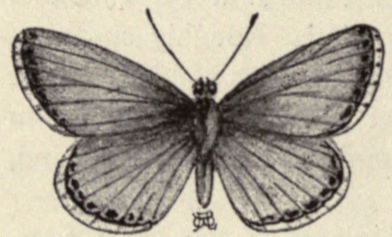

226

Male

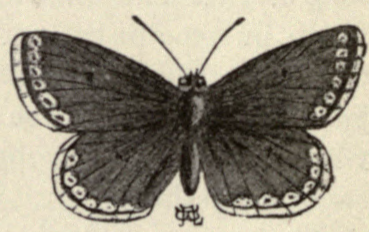

227

Female.

LYCANA CORYDON.

The pupa (Fig. 224) is without angles or keels. Several larvæ observed during the past summer ( 1892$)$ did not suspend themselves before assuming the chrysalis form, but retired just beneath the surface of the ground, and, having 
drawn together the loose earth with a few threads of silk, there turned. The anterior part of the chrysalis and the wing-cases are dull pale green, while the posterior part is dingy yellow. The abdomen is covered with very short hairs.

The costal and hind margins of the fore-wings of the imago (Figs. 225 to 227 ) are very slightly convex; all the margins are entire. The fringe is white, with dark marks at the end of the nervures. The upper surface of the male (Fig. 226) is very pale silvery-blue, becoming dark brown towards the hind-margin, with a series of dark dots inside the same margin, fairly distinct on the hind-wings. The upper surface of the female (Fig. 227) is dark smokybrown, with a small discoidal black spot on each forewing, and a marginal series of red spots, which are somewhat indistinct on the fore-wings, but on the hindwings are black-centred and bounded above with black arches. The blue scales with which the base of the wings of the female are sprinkled are of the same tint as the blue of the male. On the under-surface (Fig. 225) the markings can scarcely be distinguished from those of $L$. beliargus, but possibly the markings of $L$. corydon may be a little less distinct, and the black spots on the fore-wings may be a little larger than is the case with $L$. bellargus.

L. argiolus, Linn. (Azure Blue or the Holly Blue) (Figs. 228 to $23 \mathrm{I}$ ), commences the division of the Blues from which the red spots are absent. Its home is in the south of England, but it has been found in Durham and the Lake Districts.

The eggs are laid on the flower-stalks of Holly-flowers (Ilex Aquifolium), on the Ivy (Hedera Helix), and probably on the Alder Buckthorn (Rhamnus Frangula), the Dogwood (Cornus sanguinea), and the Spindle-tree (Euonymus europaus). There are two broods usually, 
and it almost seems that the earlier one affects hollyblossoms, while the latter prefers to feed on the ivy. The first flight of butterflies occurs at the end of April and in May. The eggs are laid on the holly, and the larvæ feed on the flower-buds, young berries, and young leaves. They are full-fed in about a month, and the pupæ, which are fastened to the leaves, come out in about eighteen days. The second flight occurs in July or August. The second brood of larvæ feeds for about forty day in August and September, the winter being past in the pupa stage.

The full-grown larva (Fig. 228) is about sin. long, and of the usual Lycana shape. It exhibits considerable variation as regards colour. One form is green with a paler streak on the dorsal ridges and thin, double, oblique lines on the sides, with a yellowish-white margin to the sub-spiracular dilatation. The head is almost black. The round spiracles may be described as flesh-coloured, and the skin is covered with yellowish warts each emitting a white hair. The green of the ground-colour varies, and some individuals are marked with pink or black. The food-plant has something to do with these differences. While the larva is not feeding, and waiting for the pupal change, the colour becomes greyish-pink.

The pupa, which is about $\frac{3}{8} \mathrm{in}$. in length, is stout and has on the dorsal surface of the thorax the slightest trace of a keel ; the wing-cases are long. The colour is pale brownish-yellow, except the wing-cases which are grey. These latter are smooth, whereas the rest of the body is covered with tiny brown hairs. The markings are a dark-brown line on the back of the thorax, which is continued down the abdomen as a series of dashes. The abdomen also bears a sub-dorsal series of larger 
dark brown marks, while the thorax bears oblique rows of small brown spots. Tiny brown spots are also to be found on the wing-cases, which are outlined in brown.

All the wings of the imago (Figs. 229 to $23 \mathrm{I}$ ) are entire, and the costal and hind margins are convex. The fringe is white, with black marks at the ends of the nervures in
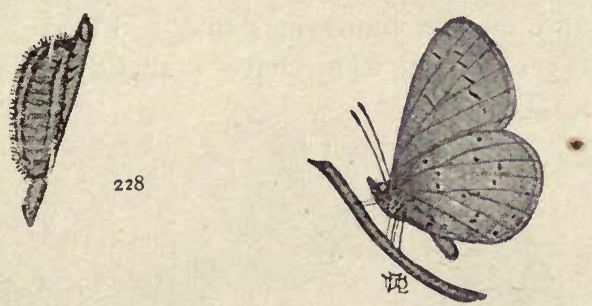

229

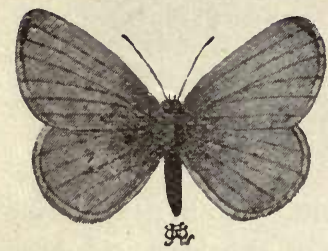

230

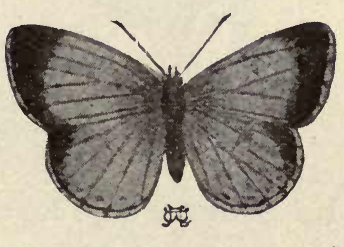

231

Male.

Female.

LYCÆNA ARGIOLUS.

the female (Fig. 23r), and of those of the fore-wings in the male (Fig. 230). The upper surface of the male is pale sky-blue, somewhat resembling $L$. bellargus, but not at all approaching it in intensity of colouring. There is a black line between the blue and the fringe, which line increases in width on the fore-wings towards the tip. The female, whose ground-colour is similar to that of the 
male, except that the wings are sprinkled with black scales, has on the fore-wings a wide black margin, broadest at the tip. On the hind-wings also the tip is black, and there is after that a small black spot between each pair of nervures. The under-surface (Fig. 229) is pale whitish-blue in colour, with faint black, linear discoidal spots on all the wings, and besides, on the fore-wings about eight small black marks, and on the hind-wings about fifteen. Many of the marks on both wings have a slightly paler circumscription.

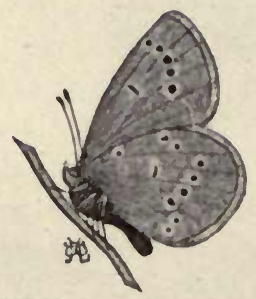

232

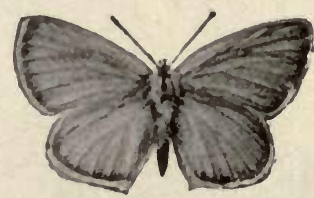

233

LYCENA SEMIARGUS.

L. semiargus, Rott., L. acis, Schiff. (Mazarine Blue) (Figs. $23^{2}$ and 233), is one of the least common of our butterflies, and possibly can scarcely be said to be a British butterfly at all at the present moment, though some years ago it used to be fairly common. In the first half of the century it could be taken in several counties-Lincoln, Cambridge, Warwick, Gloucester, Hereford, Monmouth, Glamorgan, Somerset, Dorset, and Hants; but no locality could be given for it now, though perhaps it may still be present in some undisturbed districts, especially as it might be passed over on the wing, from its resemblance to one or two 
other Blues. Till a few years ago it held its ground in a locality near Cardiff, but seems now to have quite disappeared from there also It is out in June and July.

The costal and hind margins of the wings of the imago (Figs. 232 and 233) are convex and entire; the fringe is white. The upper surface of the male is a fine purpleblue, becoming black just inside the fringe; the nervures are dark. The upper surface of the female is dark brown. The under-surface (Fig. 232) is greyish-brown

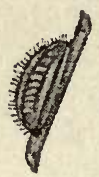

234
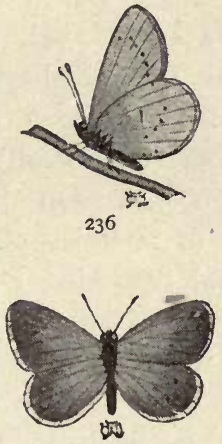

237

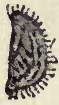

235

LYCENA MINIMA.

with pale blue scales towards the base of the wings. On each wing besides a black discoidal streak edged with white there are several white-edged black spotsfive on each fore-wing and nine on each hind-wing.

L. minima, Fues., L. alsus, Fabr. (Bedford Blue, or Little Blue) (Figs. 234 to 237), is far the smallest of the Blues and, indeed, of all our butterflies. It is moreover inconspicuous, and certainly cannot be said to make up in beauty what it lacks in size. Though 
usually met with on the chalk and limestone, L. minima is widely distributed over Great Britain; but it is not present everywhere throughout the island.

The eggs are laid about mid-June on the flower-heads of the Kidney Vetch (Anthyllis vulneraria). The young larvæ come out in less than a week, and feed by preference on the seeds. They are full-fed at the end of July, and suspend themselves for pupation, but do not turn till the beginning of the next June. The imago comes out after two or three weeks, and lives but a short time.

The full-grown larva (Fig. 234), which is about $\frac{1}{3}$ in. long and of the usual Lycana shape, is brownish fleshcolour, some specimens having a pinkish tinge, some inclining to chocolate. The dorsal stripe is of a deeper tint than the ground-colour. On each side is a subdorsal line consisting of a series of dark brown marks. The edge of the lateral dilatation bears a whitish stripe, which is continued round the anal extremity. The caterpillar is covered with short, dark brown hairs; the head is black.

The pupa (Fig. 235), which is not much more than $\frac{1}{4}$ in. long, is sometimes, at least, not suspended. The colour is light stone-colour, with tiny black specks. A black, somewhat broken stripe runs down the back, and is followed on each side by a row of short, oblique black dashes. All parts of the body, except the cases of wings, legs, and antennæ, are covered with whitish hairs; the wing-cases are marked with grey.

The costal and hind margins of the wings of the imago (Figs. 236 and 237) are convex and entire; the fringe is white and unmarked. The upper surface (Fig. 237) is dull sepia-brown, sprinkled with silvery scales in the male; the under-surface (Fig. 236) is pale grey, of a bluish tinge 
in the male. On each wing is a pale discoidal streak. The fore-wings also bear a row of seven small, whiteedged black spots, while the hind-wings have about eleven of a similar nature scattered somewhat irregularly over each wing.

L. arion, Linn. (Large Blue) (Figs. 238 and 239), is a local butterfly, and by no means common where it occurs at all. It may be sought for on rough, broken ground on hill sides, in old quarries, on flowery commons, and in other similar spots. Should arion be

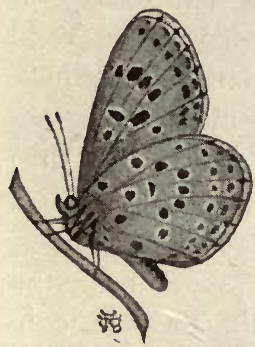

238

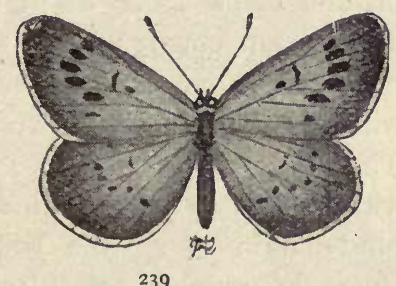

239

LYCENA ARION.

sighted, an easy capture will probably be made, for its flight is somewhat weak. Its large size and dark appearance will easily distinguish it on the wing from the rest of the Blues.

The imago appears at the end of June or beginning of July, and the eggs are laid about the same time on Wild Thyme (Thymus serpyllum), usually on the flowers. They hatch in about a week, but little appears to be known of the larva or pupa, and it is not certain in what state the insect passes the winter.

$L$. arion unfortunately seems to be dying out in 
England, though Newman and others mention its having occurred in the following counties-in some localities in considerable numbers: Bedford, Huntingdon, Buckingham, Northampton, Hereford, Gloucester, Somerset, Devon, Dorset, Wilts, Hants, Shropshire, and Kent.

The costal and hind margin of all the wings of the imago (Figs. 238 and 239) are convex, the hind-wings are slightly inclined to be scalloped, and the fringe is white. The upper surface (Fig. 239) is a kind of steelblue, or a dark blackish-brown suffused with blue scales. The blue scales, however, are confined to the central portion of the wings, the margins being left darker by their absence. Near the centre of the wings are several distinct black spots, as well as a few others less distinct. Their arrangement will be seen from the illustration. As no other of our Blues possesses spots of this nature, they will be sufficient for the recognition of the one before us. The under-surface (Fig. 238) is pale brown in colour, with a double row of indefinite black spots near the hind-margin of all the wings, and within these a considerable number of black spots with white circumferences-about nine on each fore-wing and thirteen on each hind-wing. The sexes are similar.

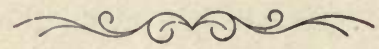




\section{ERYCINID E.}

\section{Nemeobius, Steph.}

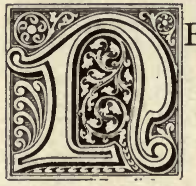

EMEOBIUS is the only European genus of the family Erycinida, and the genus is represented by but the one species here described, which may be distinguished by the males possessing four perfect legs, while the females have six.

N. lucina, Linn. (Figs. 240 to 243 ), is usually called the Duke of Burgundy Fritillary, an unfortunate title, since it at once gives a wrong idea of the insect's position among our butterflies. The difficulty might be avoided, perhaps, by dropping the word Fritillary, and calling it the Duke of Burgundy simply. It is a pretty little butterfly, closely resembling the Fritillaries in general appearance, and, like many of them, making sylvan scenes its home. In such spots it may be taken, flitting along the hollows and pathways. There are numerous localities for it throughout England, from north to south, but it cannot be said to be distributed generally, and need not be expected away from woods. 
The eggs are laid at the beginning of June on the under-side of the leaves of the Cowslip (Primula veris) or Primrose (Primula vulgaris). The larvæ may be found from June till August or September, the winter being passed in the pupal stage. The imagines come out in June.
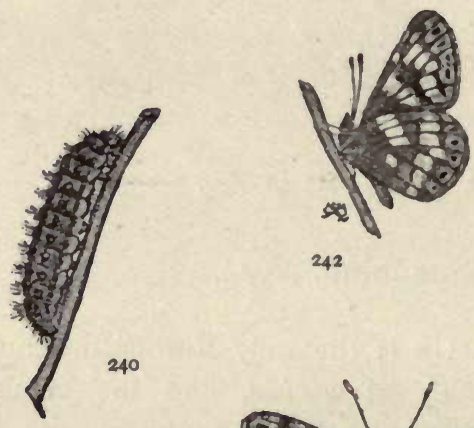

242

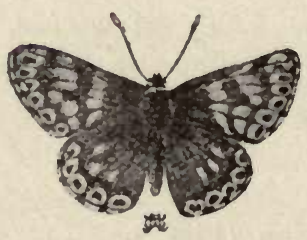

241

243

\section{NEMEOBIUS LUCINA.}

The larva is woodlouse-shaped (Fig. 240). The colour of the head is shiny orange-brown, of the body dark yellowishbrown down to the spiracles paler below them. The body is downy and, especially on the back, bears many warts, each of which emits a bundle of stiff, curved hairs. There is a dark, interrupted dorsal stripe of blackish hairs, and on each side are two lateral ones. The spiracles are outlined in black. 
The stout, rounded pupa (Fig. 24r) which is attached by the anal extremity to the food-plant, and girt, is very pale brown in colour, covered with numerous black spots, and having a -dark streak on the costal margin of the wing-cases. The whole body is covered with rather long brown hairs.

The costal margin of the fore-wings of the imago (Figs. 242 and 243) is nearly straight, and the hindmargin slightly convex. The hind-margin of the hindwirgs is scalloped, but not deeply, while the anal angle has an indication of a protuberance. The fringe is white, with brown spots at the ends of the nervures; the body is black. The dark brown ground-colour of the upper surface (Fig. 243) is relieved on the fore-wings by three irregular bands of orange spots, the marginal ones being black-centred. On the hind-wings the marginal band is continued, and has large black centres; but between this band and the base of the wings are only a few orange spots. The ground-colour of the under-surface (Fig. 242) is much lighter. The marginal band is repeated on all the wings, but does not show up so distinctly. The markings on the rest of the fore-wings resemble those on the upper surface; on the hind-wings, however, between the marginal band and the base, are two bands of large and clear dark-edged white spots. Owing to the presence of these spots and the richer ground-coiour, the under-surface is much more beautiful than the upper.

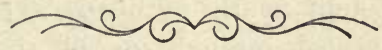




\section{CHAPTER VI.}

\section{HESPERIIDAE.}

\section{The Skippers.}

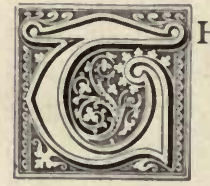

$\mathrm{HE}$ Hesperiida constitute a distinct and very interesting little group, falling naturally at the end of the butterflies, and serving as a kind of connecting-link between them and the moths, which they somewhat closely resemble in many points. The Skippers have stout bodies and rather thick wings; the heads are broad, and the roots of the antennæ distant. The antennæ themselves are either curved at the end, something like those of the Foresters and Burnets among the moths, or terminate in a short hook. The flight of the Skippers is not continuous, like that of a normal butterfly, but in short, sharp jerks; while at rest the hind-wings are held in an almost horizontal position, the fore-wings being kept nearly vertical. The shape of the larvæ and pupæ also reminds us of the moths. The . larvæ too feed under the shelter of leaves, which they fasten together with threads of silk. The slender, unangled pupæ are contained in rudimentary cocoons, also 
between leaves of the food-plant. The imagines have six perfect legs adapted for walking. The following artificial key to the species of the Hesperiida may be found useful:

A. Sexes similar; ground-colour black or brown.

I. Black with white spots $\ldots \ldots \ldots \ldots \ldots$. S. malva.

2. Black with yellow spots ............ C. palamon.

3. Dark brown, with darker brown marking, and a few small white spots ......... $N$. tages.

B. Male distinguished from the female by a black bar on the fore-wings; ground-colour rich orange-brown.

a. Small; without hooks to antennæ.

I. Colour uniform; bar on male, long, continuous, curved, distinct; under-side of antennæ, pale buff, not dark ..........

H. thaumas.

2. Colour uniform; bar on male, short, broken, usually indistinct; under-side of tips of antennæ black ..............

3. With a fan-like arrangement of light markings on fore-wings.............. H. acteon.

b. Larger; with hooks to antennæ.

I. Under-surface yellowish, almost uniform $H$. sylvanus.

2. Under-surface darker, with square white markings ...................... H. comma.

\section{Syrichthus, $B d v$.}

The genus Syrichthus is represented by the single species following:

S. malvæ, Linn., S. alveolus, Hübner (Grizzled Skipper) (Figs. 244 and 245), is a fairly .common little butterfly in grassy spots near woods in England and parts of Scotland. When on the wing it is very difficult to follow, and so does not fall an easy prey to the pursuer. Should a capture be effected, it must be remembered that a Skipper- is not like an ordinary butterfly, and no attempt should be made to kill it by 
pinching the thorax; such a proceeding would almost certainly destroy the beauty of the specimen. All Skippers had better be boxed and taken home, or killed in the cyanide-bottle on the spot.

The perfect insect is out in May, and continues but a short time upon the wing. The eggs are laid about the beginning of June on the Bramble (Rubus fruticosus), the Strawberry-leaved Potentilla (Potentilla Fragariastrum), and perhaps on the Musk Mallow (Malva moschata), the Raspberry (Rubus Idcus), the Wild Strawberry (Fragaria vesca), and possibly one or two species of Potentilla besides that mentioned above. The eggs hatch

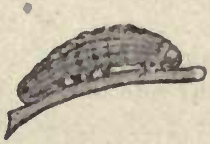

244

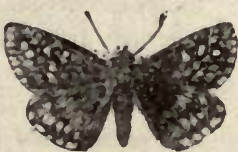

245

SYRICHTHUS MALVE.

in nine or ten days, and the pupa may be found about September.

The larva (Fig. 244), which is between $\frac{1}{2}$ in. and $\frac{3}{4} \mathrm{in}$. in length when full-grown, is somewhat spindle-shaped. The body is yellowish-green, with a reddish tinge on the fore-part of the back, and is covered with short hairs. There are indistinct dorsal, subdorsal, and spiracular lines, and the head is dark brown.

The long, smooth, unangled pupa is contained in a slight cocoon between bramble-leaves fastened together by threads of silk. The dorsal surface bears reddishbrown hairs. The ground-colour is reddish-grey, the wing-cases having a pinkish tinge and the dorsal surface 
of the abdomen being brownish. On the anterior parts of the pupa are some dark brown marks, and there is a row of spots across each segment of the abdomen.

The costal margin of the fore-wings of the imago (Fig. 245) is nearly straight, the hind-margin of all the wings is slightly convex, and the fringe is black and white. The colour of the upper surface is black, chequered with variously-shaped white marks. The under-surface resembles the upper, but is paler. The sexes are similar. There is a variety in which several of the spots on the upper surface of the fore-wings coalesce and give the butterfly a very distinctive appearance. This goes by the name of $S$. malve var. lavaterce.

\section{Nisoniades, Hïbner; Thanaos, Boisduval.}

Like Syrichthus, Nisoniades is represented by but a single species.

N. tages, Linn. (Dingy Skipper) (Figs. 246 and 247), though not so common as the last butterfly, is found throughout England and in parts of Scotland. It should be sought for on dry banks, on hill-sides, and in similar localities. It is common in the south-east corner of England.

The imagines come out in May. The eggs are laid about the end of the month on the Bird's-foot Trefoil (Lotus corniculatus). They hatch early in June, and the larvæ are full-grown at the end of July, producing, probably, a second flight of butterflies.

The full-grown larva (Fig. 246) is somewhat spindleshaped and from $\frac{3}{4}$ in. to rin. in length. It is yellowish-green, shagreened with dark points. The dorsal stripe is of a darker green and is followed on each side by a sub-1 dorsal, pale, dark-edged one. The small spiracles are 
red and the spiracular line is whitish-green. The head is dark brown.

The unangled pupa is green on the thorax, but tinged with red on the abdomen.

The costal margin of the imago (Fig. 247) is nearly straight, and the hind-margin of all the wings slightly convex. The fringe is brown, as is also the groundcolour of all the wings. On the fore-wings are two rows of dark brown spots, the one nearest the base being interrupted. The hind-wings are of a much darker brown ground-colour, with a few indistinct pale markings. Inside the fringe on all the wings is a
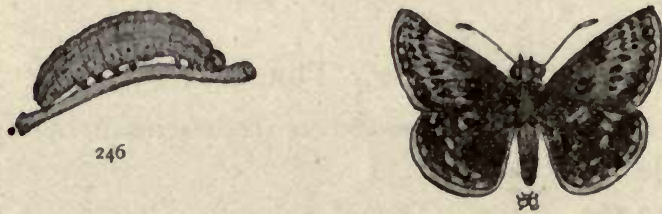

247

NISONIADES TAGES.

fine dark line, succeeded inwards by a row of tiny whitish dots. The under-surface is pale whitish-brown, with a few indistinct whitish dots, consisting principally of a line just inside the fringe. The sexes are similar.

\section{Hesperia, Boisduval.}

Hesperia contains five British species- $H$. thaumas, $H$. lineola, $H$. actron, $H$. sylvanus, $H$. comma, all of them possessing a rich orange-brown ground-colour, and the males in each case having a black bar near the base of the fore-wings, distinguishing them from the females. The last two, which are considerably larger 
than the others, have their antennæ terminated in a hook. All five butterflies have a concave bend on the hind-wings near the anal angle.

H. thaumas, Hufn., H. linea, Fabr. (Small Skipper) (Figs. 248 to 250 ), is pretty generally distributed throughout England by the sides of hedgerows, on commons, and in many other situations; but owing to its small size and

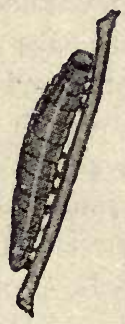

248

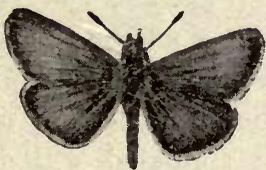

249

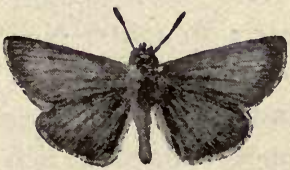

250

Male.

Female.

HESPERIA THAUMAS.

inconspicuous colouring is probably seldom seen except by entomologists.

The eggs are laid towards the end of July, and the young larvæ come out early in August. They feed on grasses, two that they take to well being the Meadow Soft-grass (Holcus lanatus) and the Slender False Bromegrass (Brachypodium sylvaticum). After spending the 
winter as larvæ they spin up during June, and the perfect insects emerge in July.

The full-grown larva, which is under rin. in length, has a flattened ventral surface and tapers a little towards both extremities. The body is light green, the head being darker and rough. On the fore-part of the body are numerous extremely fine black points. The dorsal stripe is of a darker green than the general colour, with a stout paler green line down the centre of it and a similar one still paler on each side. The subdorsal line is pale green, and the spiracles are reddish, while below them is a whitish line.

The pupa, which is about $\frac{3}{4}$ in. in length, is, when it has not long turned, similar in colouring and marking to the larva, and very closely resembles the pupa of $H$. actron, but the beak projecting from the head is shorter and less sharply-pointed than is that of the last named.

The costal margin of the imago (Figs. 249 and 250) is nearly straight. Near the anal angle of all the wings is a concave hollowing of the margin most pronounced on the hind-wings; the fringe is pale. The ground-colour of the upper surface is rich orange-brown sprinkled with black scales on the hind-wings and at the base and hind-margin of the fore-wings. Just inside the fringe is a distinct black line. The male (Fig. 249) is distinguished from the female (Fig. 250) by the black bar near the base of the forewings. The under-surface is very plain, being greyishbrown with a good sprinkling of black scales.

H. lineola, Och. (New Small Skipper) (Fig. 25I), was, in $189 x$, added to the list of British Butterflies. Before that time it had been confused with $H$. thaumas, which it very closely resembles, with which it usually flies, and with whose time of appearance on the wing it almost or quite 
coincides. - It was already known to have a wide range in Europe, extending from Scandinavia in the north to the extreme south, and even beyond the Mediterranean into North Africa.

With regard to localities, those at present known are Leigh, Harwich, and Benfleet, Essex; Shoeburyness; Southend; Fens of Huntingdon; Cambridgeshire ; near Sudbury, Suffolk; as well as in Jersey.

Each female lays on an average at least thirty to forty eggs, which she deposits in July or August inside the sheath formed at the junction of the grass-blades with the stem. The larvæ appear in the middle of the following April and feed on grass, a genus that they take to readily being Triticum. Towards the end of June the pupal state

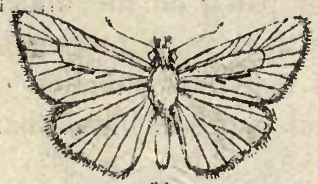

s

Fig. 251. Hesperia lineola.

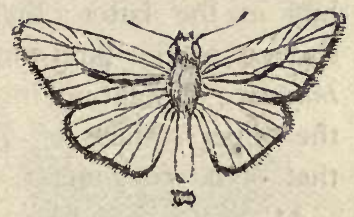

Fig. 252. Hesperia thaUmas.

is assumed and lasts three weeks or rather less, the imagines appearing about mid-July.

Mr. F. W. Hawes, to whose description of the early stages of lineola in The Entomologist, xxv., p. I77, we are indebted for the following, says that the larva is yellowish-green, having a rather broad dorsal stripe of darker green, which stripe is continued as a distinct brown mark over the head to the mouth; the head has also two other marks, one on each side of the central brown one. There are two thin subdorsal yellow stripes, and a light line traverses each side just below the 
spiracles; the segmental divisions are yellow, and the belly and legs of a deeper and clearer green. It feeds at dusk, and no doubt during the night, near the tops of the blades of grass. The resemblance of the full-grown larva to a grass-blade is very remarkable.

When full-fed the larva spins the grass stems together low down by a network of white silk and changes to a long yellowish-green pupa, in which the dorsal stripe of the larva is retained.

By comparing lineola (Fig. 251) with thaumas (Fig. 252), it will be seen that the bar on the upper surface of the fore-wings of the male is in the former short, divided, and usually indistinct; while in the latter it is long, curved, continuous, and very distinct; that the undersurface of the tip of the antennæe is black in the former, buff in the latter; that the fulvous patch on the undersurface of the hind-wings near the anal angle present in thaumas is wanting in lineola, and that the coloration of the upper surface of lineola is much more suffused than that of its congener.

H. actæon, Rott. (Lulworth Skipper) (Figs. 253 to 256), is one of the most local of our butterflies, being found only in certain spots along the south coast of England, between Swanage and Sidmouth, the best-known localities being Lulworth Cove, where the butterfly was first discovered in 1832 , and Burning Cliff, between that place and Weymouth. It used sometimes to be very abundant in detached sheltered spots facing south, but is probably less common now than formerly. $H$. actaon is an active little butterfly, very difficult to follow in its flight, but it may often be taken in dull weather resting on teasles, thistles, and brambles. Specimens for the cabinet ought to be secured within a few hours at most after leaving the chrysalis 
The larva feeds on the Heath False Brome-grass (Brachypodium pinnatum), Couch-grass (Triticum repens), and probably other grasses. It is full-fed about the end of June, and the imagines come out about mid-July and sometimes continue into September.

The full-grown larva (Fig. 253) is between $\frac{3}{4}$ in. and rin. in length, and tapers somewhat to both extremities.

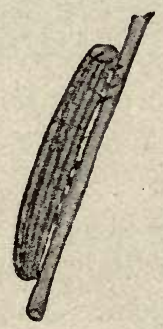

253

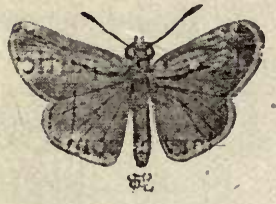

255

Male.

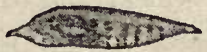

254

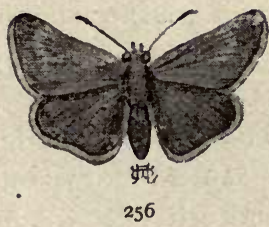

Female.

HESPERIA ACTEON.

The head is large, brown at first, then paler; the colour of the body is whitish-green, with a darker streak on the back edged with yellow, and down the centre of this streak is a pale line. A narrow yellow line follows this on each side, and below that is a broader one of the same colour. The spiracles are fleshcoloured, and are contained in a pale streak. 
The pupa (Fig. 254) is $\frac{3}{4}$ in. in length; it is pointed in front, while the anal extremity is flattened and furnished with hooks. The tongue-case is free from the body. The colouring resembles that of the larva, but as the time approaches for the imago to appear it becomes pinkish anteriorly, then purplish, while the dorsal surface of the abdomen assumes a brownish colour. As the change approaches more closely, the colours become darker still.

The imagines (Figs. 255 and 256 ) very closely resemble those of $H$. thaumas, but they are rather thickly sprinkled with black scales, and there is a fan-like series of light yellowish spots on the fore-wings.

H. sylvanus, Esper. (Large Skipper) (Figs. 257 to 261), is the largest member of the group, but except by entomologists is probably seldom seen, owing to its inconspicuous colouring and abrupt, jerky style of flight. It is, however, pretty generally distributed throughout England, especially in the south. It should be sought for in grassy spots, by road-sides, and so on-particularly near woods.

The eggs are laid in July, and the larvæ come out in the same month and feed on the Broad-leaved Hairy Woodrush (Luzula pilosa) as well as on various grasses, amongst them being Cock's-foot-grass (Dactylis glomerata), Couch-grass (Triticum repens), and Soft-grass (Holcus lanatus). The larvæ make for themselves silken hibernacula amongst the grass-blades in early autumn, and in them pass the winter. They are full-fed in May, and the imagines come out in that month or the next.

The larva (Fig. 257), which is of the shape common to the group, is, when full-fed, over rin. in length and bluish-green in colour, with a darker stripe down the back and a light one in the spiracular region above the 
feet. The head is large and of a bright pinkish-brown colour.

The pupa (Fig. 258), which is more than $\frac{3}{4}$ in. in length, is purplish-brown in colour, and is to be found enclosed in a blade of grass, the edges of which have been drawn together with silken threads. It has a prominent point
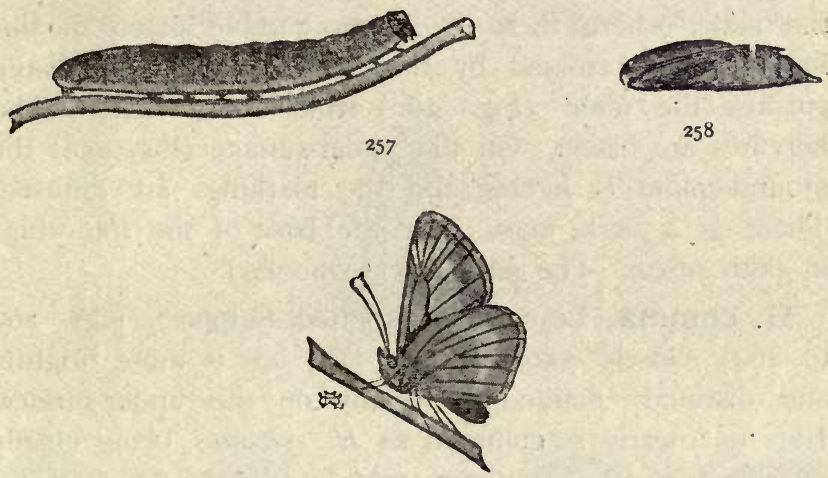

259

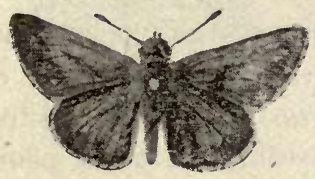

260

Male.

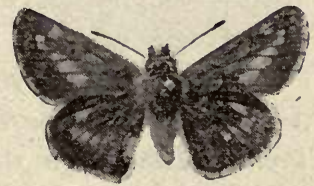

26r

Female.

HESPERIA SYLVANUS.

at the anal extremity, and the end of the long tonguecase is detached from the body.

The costal margin of the fore-wings of the imago (Figs. 259 to 26I) is nearly straight, but possibly a little concave; the hind-margin of all the wings is rounded, except near the anal angle of the hind-wings, where there 
is a rather conspicuous concavity; the fringe is pale yellow. The ground-colour of the upper surface is a bright orangebrown, edged with a considerable width of brown along the hind-margin. The same colour is also found at the base of the hind-wings and even of the fore-wings of the female (Fig. 26r), leaving the bright orange more or less as a series of spots, except on the fore-wings of the male, where there is a considerable patch of this lighter colour, crossed by the black streak which distinguishes the male (Fig. 260) from the female. The nervures are black. On the under-surface (Fig. 259) the ground-colour is lighter and the markings are diffused. There is a dark mark near the base of the fore-wings in both sexes. The antennæ are hooked.

H. comma, Linn. (Silver-spotted Skipper) (Figs. 262 to 264), closely resembles the last, but is more brightly and distinctly marked, especially on the under-surface. It is not nearly so common as $H$. sylvanus, being chiefly restricted to the southern part of England. Its lifehistory, too, is not well known.

The eggs are laid late in the summer and hatch about March in the next year. The larvæ are said to feed on the Bird's-foot (Ornithopus perpusillus) and the Bird's-foot Trefoil (Lotus corniculatus), and possibly on other plants of the order Leguminosa. The imago appears in July or the next month.

It has been mentioned from the following counties where it may sometimes occur abundantly: In the Midlands, in Berks, Bucks, Derby, Gloucester, Northants and Oxon; in the east, in Cambridge, Hertford, and Kent ; in the south, in Devon, Dorset, Hants, Wilts, Surrey, and Sussex; and in the North, in Yorkshire.

The margins of the imago (Figs. 262 to 264 ) are similar in shape to those of $H$. sylvanus, except that the hollow 
near the anal angle of the hind-wings may be a little deeper; the fringe is perhaps paler than in the last-named butterfly. In general arrangement the ground-colour and markings of $H$. comma resemble those of $H$. sylvanus, but the contrast is greater and the spots are smaller, so that the markings seem more distinct. There is considerable difference however on the under-surface (Fig. 262). $H$. comma has a much greyer ground-colour,

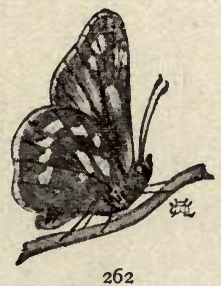

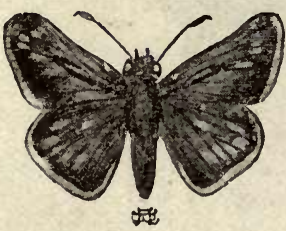

263

Male.

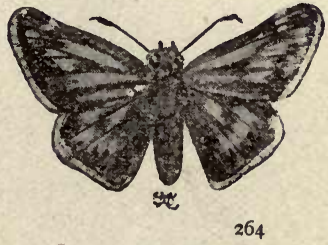

Female.

HESPERIA COMMA.

and is marked with very distinct, somewhat square whitish spots. The black mark on the fore-wings distinguishes the male (Fig. 263) fron the female (Fig. 264). The antennæ are hookcd.

Carterocephalus, Laderer.

In Britain Carterocephalus is represented by one species only. 
C. palæmon, Pall, C. paniscus, Fabr. (Chequered Skipper) (Figs. 265 and 266), is not a common butterfly, its home being in a few eastern and east-midland counties -Lincoln, Suffolk, Huntingdon, Northampton, Nottingham, and Oxford. It also occurs in the south, in Hampshire, and has been reported from North Wales.

The eggs are laid and hatched in June. The larva feed on the Slender False Brome-grass (Brachypodium sylvaticum), the Hairy Brome-grass (Bromus asper), and probably on other grasses also. The winter is passed

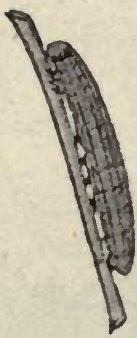

265

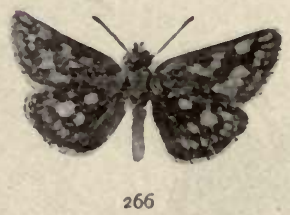

CARTEROCEPHALUS PALAMON.

in the larval stage, the pupal state being taken in April The perfect insects appear about May.

The larva (Fig. 265), which is over rin. in length when full-grown, is pale bluish-green in colour, with several longitudinal lines, many of them indistinct. The chief lines are a darker green dorsal one with whitish edging, then a brcad paler green one, next a dark green one, and then a whitish one. The head and second and third segments have dark marks at first, but they become green eventually. During hibernation the larva 
becomes smaller, and loses much of the green from its colouring.

The slender pupa is about $\frac{3}{5}$ in. in length. It has a sharp anterior spike, and a flat anal one bearing hooks. In colour it is pale cream, with a narrow dark brown dorsal line. Below this, on each side, are two rustcoloured lines, and a third in the region of the spiracles. The tongue-case is dark brown.

The costal margin of the fore-wings of the imago (Fig. 266) is nearly straight, and the hind-margin convex. The hind-margin of the hind-wings has the concavity near the anal angle which is characteristic of all the Skippers except the two already described; the fringe is brown. The antennæ are curved at the tip, but not hooked. The ground-colour of the upper surface is nearly black. Besides a row of indistinct orange spots near the hind-margin, there are about ten bright orange spots of various shapes on each fore-wing and about four on each hind-wing. The under-surface is richer than the upper-the ground-colour is lighter, the spots are more numerous, and many are edged with a fine dark line. 


\section{CHAP'TER VII.}

\section{COLLECTOR'S CALENDAR.}

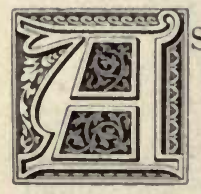

$S$ a help to the inexperienced collector the following calendar has been drawn up, so that he may always have at hand for reference a convenient list of the larvæ, pupæ, and imagines that he may expect to meet with on his excursions. It must be understood that several of the names were included with a good deal of reserve, but this will only spur on the genuine entomologist to add new facts to those already known. In consulting the calendar allowance must always be made for the forwardness, or otherwise, of the season, as this may make two or three weeks' difference in the time of appearance of any particular insect, especially the early ones. A further point to note is that eggs of butterflies that hibernate as imagines should not be sought for till the spring.

\section{January and February.}

Butterfly-life is at a standstill during these months, the winter being passed in a state of hibernation, which may take place at either of the four stages-egg, larva, 
pupa, or imago ; but, as far as each species is concerned, the state in which the winter is passed is invariable, though precocious individuals may sometimes outstrip their fellows in development.

\section{Eggs.}

Thecla betula

$W$-album

pruni

quercus
Lycana agon

Hesperia lineola

comma

[Lycana batica]

\section{Larvæ.}

Aporia cratagi

Argynnis selene

euphrosyne

latona

aglaia

adippe

paphia

Melitaa aurinia

cinxia

athalia

Limenitis sibyluz

Apatura iris

Melanargia galatea

Erebia epiphron

athiops

Pararge egeria

megara

Satyrus semele

Epinephele ianira

tithonus

hyperanthes

Canonympha typhon

pamphilus

Polyommatus phlocas

Lycana astrarche

icarus

bellargus

corydon

minima

arion

Nisoniades tages

Hesperia thaumas

acteon

sylvanus

Carterocephalus palamon

\section{Pupæ.}

Papilio machaon

Leucophasia sinapis

Pieris brassica

rape

napi

daplidice

Euchloë cardamines

Thecla rubi

Lycana argiolus

Nemeobius lucina

Syrichthus malva 


\section{Imagines.}

Colias hyale edusa

Gonopteryx rhamni

Vanessa C.album

polychloros
Vanessa urtica

io

antiopa

atalanta

cardui

[Danais erippus]

Nothing is known of the state of hibernation of Lycana acis, while there is considerable doubt about that of Hesperia comma, Pararge egeria, P. megara, Canonympha pamphilus, Lycana arion, Carterocephalus palcemon, Colias hyale, and $C$. edusa.

Occasionally a few butterflies may be found on the wing, having been deceived as to the time of the year by an exceptionally warm and bright day. The butterflies so deceived will belong to the group that hibernates in the imago stage, or will be one of the common Whites, Pieris brassica, $P$. rapa, or possibly $P$. napi, $P$. rapa being the earliest of the three upon the wing.

\section{March.}

Though we are able to say that the winter's sleep of the butterfly-world is beginning to get a little disturbed, yet during March very few advances are made from the state of affairs at the end of February. No new butterflies enter the pupa state (except, - perhaps, Polyommatus phloas); but, should the weather be open, we may expect some of the hibernating larvæ to commence feeding. Amongst them we might perhaps find Melitaa aurinia, M. cinxia, M. athalia, Argynnis euphrosyne, A. selene, Pararge egeria, P. megara, Polyommatus phloas, and Thesla rubi. Hesperia comma may be expected to leave the egg this month. 
The following imagines may possibly be seen, as there are records of their having occurred during this month or earlier: Pieris rape, Gonopteryx rhamni, Vanessa $C$-album, $V$. polychloros, $V$. urtica, $V$. io, $V$. antiopa, and Lycana argiolus.

\section{April.}

With the advent of April the work of the entcmologist commences in earnest, especially if the weather happens to be genial.

Aporia cratagi

Argynnis selene euphrosyne

latona

aglaia

adippe

paphia

Melitaa aurinia

cinxia

athalia

Limenitis sibylla

Apatura iris

Melanargia galatea

Erebia epiphron athiops

Pararge megara

Satyrus semele

Epinephele ianira
Larvæ.

Epinephele tithonus

hyperanthes

Conmympha typhon

pamphilus

Lycana astrarche

icarus

bellargus

corydon

minima

arion

Nisoniades tages

Hesperia thaumas

lineola

actcoon

sylvanus

comma

Carterocephalus palamon

Of the above-named butterfly-larvæ many will be feeding, though a few will usually wait a week or two longer before trusting our uncertain climate.

Papilio machaon

Pieris brassica

rapa

napi
Pupæ.

Pieris daplidice

Euchloë cardamines

Leucophasia sinapis

Argynnis euphrosyne 


\section{PUPAE-continued.}

Melitea aurinia cinxia

Pararge egeria inegara

Thecla rubi

Lycana astrarche
Lycana argiolus Nemeobius lucina Syrichthus malva Nisoniades tages Carterocepha?'us palamon

\section{Imagines.}

Pieris brassica rapa napi

Euchloë cardamines Leucophasia sinapis Gonopteryx rhamni Argynnis euphrosyne Vanessa C-album polychloros urtice
Vanessa io antiopa atalanta cardui Pararge egeria Thecla rubi Polyommatus phloas

- Lycana argiolus Syrichthus malva Nisoniades tages

The number of species observed will depend very greatly on the forwardness of the season.

\section{May.}

During this and the next three or four months the - entomologist will have his hands fully occupied. He may be expected to find the following:

\section{Larvæ.}

Aporia cratagi

Pieris brassica

$$
\text { napi }
$$

daplidice

Euchloë cardamines

Gonopteryx rhamni

Argynnis selene

latona

aglaia
Argynnis adippe

paphia

Melitaa aurinia

cinxia

athalia

Vanessa C-album

urtice

Limenitis sibylla

Apatura iris 
I.ARVA-continued.

Melanargia galatea

Erebia epiphron

athiops

Satyrus semele

Epinephele ianira

tithonus

hyperanthes

Canonympha typhon

pamphilus

Thecla betula

$W$-album

pruni
Thecla quercus

Polyommatus phlous

Lycana agon

icarus

corydon

minima

Hesperia thaumas

lineola

actaon

sylvanus

comma

\section{Pupæ.}

Papilio machaon Aporia crategi

Leucophasia sinapis

Argynnis selene euphrosyne

Melitaa aurinia cinxia

Erebia epiphron

Pararge megara

Epinephele ianira

Canonympha typh.hon

Thecla rubi

Lycana astrarche icarus

bellargus

corydon

Nemeobius lucina

Hesperia sylvanus

Carterocephalus palamon

\section{Imagines.}

Papilio machaon

Pieris brassica

rapa
napi
daplidice

Euchloë cardamines

Leucophasia sinapis

Colias hyale

$$
\text { edusa }
$$

Gonopteryx rhamni

Argynnis selene

$$
\text { euphrosyne }
$$

Melitea aurinia

cinxia

athalia

Vanessa $C$-album

polychloros

urtica

io

antiopa

atalanta

cardui

Pararge egeria

megara 


\section{IMAGINES-continued.}

Canonympha typhon

$$
\text { pamphilus }
$$

Thecla rubi

Polyommatus phlceas

Lycana argiades

astrarche

icarus
Lycana bellargus

$$
\text { argiolus }
$$

semiargus

Syrichthus malva

Nisoniades tages

Carterocephaius palamon

\section{June.}

\section{Larvæ.}

Papilio machaon

Pieris brassica

$$
\begin{aligned}
& \text { rapa } \\
& \text { napi } \\
& \text { daplidice }
\end{aligned}
$$

Euchloë cardamines

Leucophasia sinupis

Colias hyale

$$
\text { edusa }
$$

Gonopteryx rhamni

Argynnis euphrosyne

latona

aglaia

adippe

paphia

Melitaa aurinia

cinxia

athalia

Vanessa $C$-album

polychloros

urtica

io

antiopa

atalanta

cardui

Limenitis sibylla

Apatura iris

Melanargia galatea

Erebia athiops

Pararge egeria

$$
\text { megara }
$$

Satyrus semele

Epinephele tithonus

hyperanthes

Canonympha pamphilus

Thecla betula

W-album

pruni

quercus

rubi

Polyommatus phloeas

Lycana agon

bellargus

corydon

argiolus

Nemeobius lucina

Syrichthus malve

Nisoniades tages

Hesperia thaumas

lineola

actaon

comma

Carterocephalus palamon 


\section{Pupæ.}

Aporia cratagi

Pieris brassica

$$
\text { napi }
$$

Gonopteryx rhamni

Argynnis latona

$$
\text { aglaia }
$$

adippe

paphia

Melitaa aurinia cinxia

Vanessa C-album

Limenitis sibylla

Apatura iris

Melanargia galatea

Erebia epiphron athiops

Satyrus semele

Epinephele ianira tithonus
Epinephele hyperanthes

Canonympha typhon

$$
\text { pamphilus }
$$

Thecla betula

$$
\text { W-album }
$$

pruni

quercus

Polyommatus phlocas

Lycana agon

$$
\begin{aligned}
& \text { corydon } \\
& \text { argiolus } \\
& \text { minima }
\end{aligned}
$$

Nemeobius lucina

Hesperia thaumas

lineola

actaon

sylvanus

comma

\section{Imagines.}

Papilio machaon

Aporia cratagi

Pieris brassica

$$
\begin{aligned}
& \text { rapa } \\
& \text { napi }
\end{aligned}
$$

Euchloë cardamines

Leucophasia sinapis

Colias hyale

$$
\text { edusa }
$$

Gonopteryx rhamni

Argynnis selene

euphrosyne

paphia

Melitaa aurinia

$$
\text { cinxia }
$$

athalia

Vanessa $C$-album

urtica
Vanessa io

$$
\begin{aligned}
& \text { atalanta } \\
& \text { cardui }
\end{aligned}
$$

Limenitis sibylla

Erebia epiphron

Pararge megara

Satyrus semele

Epinephele ianira

Canonympha typhon. pamphilus

Thecla W-album

$$
\text { pruni }
$$$$
\text { rubi }
$$

Polyommatus phlocas

Lycana argiades

astrarche

icarus

bellargus 


\section{IMAGINES-continued.}

Lycana argiolus semiargus minima arion

Nemeobius lucina
Syrichthus malva

Nisoniades tages

Hesperia sylvanus comma (?)

Carterocephalus palamon

\section{July.}

Larvæ.

Aporia cratagi

Pieris brassica

rapa

napi

Euchloë cardamines

Colias hyale edusa

Argynnis selene euphrosyne

Melitaa aurinia cinxia athalia

Vanessa C-album polychloros

urtica io
Vanessa antiopa atalanta cardui

Pararge egeria megara

Canonympha typhon pamphilus

Thecla rubi

Lycana astrarche icarus minima

Nemeobius lucina Syrichthus malva Nisoniades tages Hesperia sylvanus Carterocephalus palamon

\section{Pupæ.}

Papilio machaon

Pieris brassica

rapa

napi

daplidice

Euchloë cardamines

Leucophasia sinapis

Colias hyale edusa

Gonopteryx rhamni Argynnis latona
Argynnis aglaia adippe

Vanessa C-album polychloros urtice io

antiopa

atalanta

cardui

Limenitis sibylla Apatura iris 


\section{PuPAE-continued.}

Melanargia galatea

Erebia athiops

Pararge egeria megara

Satyrus semele

Epinephele hyperanthes

Canonympha pamphilus

Thecla betula

$W$-album

quercus

rubi
Lycana agon astrarche bellargus corydon argiolus Nisoniades tages Hesperia thaumas lineola actcoon comma

\section{Imagines.}

Papilio machaon

Aporia cratagi

Pieris brassice

$$
\begin{aligned}
& \text { rape } \\
& \text { napi } \\
& \text { daplidice }
\end{aligned}
$$

Leucophasia sinapis

Gonopteryx rhamni

Argynnis latona

$$
\text { aglaia }
$$

adippe

paphia

Melitea athalia

Vanessa C-album

polychloros

urtice

io

Limenitis sibylla Apatura iris Melanargia galatea Erebia epiphron athiops

Pararge egeria Satyrus semele Epinephele ianira
Epinephele tithonus hyperanthes

Canonympha typhon pamphilus

Thecla betule $W$-album

pruni

quercus

rubi

Polyommatus phlcas

Lycana argiades

agon

icarus

corydon

argiolus

semiargus

minima

arion

Syrichthus malve

Hesperia thaumas

lineola

actroon

sylvanus

comma 


\section{August.}

Larvæ.

Papilio machaon

Aporia cratagi

Pieris brassica

napi

daplidice (?)

Leucophasia sinapis

Argynnis selene

euphrosyne

latona

aglaia

adippe

paphia

Melitea aurinia

cinxia

athalia

Vanessa C-album

atalanta

cardui

Papilio machaon

Pieris napi

daplidice

Euchloë cantamines

Vanessa polychloros

urtica

io

Papilio maihuon

Aporia cratagi

Pieris brassica

rapa

napi

daplidice

Leucophasia sinapis

Colias hyale
Limenitis sibylla

Apatura iris

Satyrus scmele

Epinephele ianira tithonus

- hyperanthes

Canonympha typhon pamphilus

Polyommatus phloeas

Lycana astrarche icarus

argiolus

minima

Nemeobius lucina

Syrichthus malva

Hesperia thaumas

sylvanus

Carterocephalus palamon

Pupæ.

Vanessa atalanta cardui

Cononympha pamphilus

Thecla rubi

Lycana icarus

bellargus

\section{Imagines.}

Colias edusa

Gonopteryx rhamni

Argynnis latona

aglaia

adippe

paphia

Vanessa C-album

polychloros 
IMAGINES-continued.

Vanessa urtica

io

antiopa

atalanta

cardui

Limenitis sibylla

Apatura iris

Melanargia galatea

Erebia epiphron

athiops

Pararge egeria

megara

Satyrus semele

Epinephele ianira

tithonus

hyperanthes

Cononympha typhon

pamphilus
Thecla betula

$W$-album

quercus

Polyommatus phlceas

Lycana batica

argiades

agon

astrarche

icarus

bellargus

corydon

argiolus

semiargus

Nisoniades tages

Hesperia lineola

actaon

sylvanus

comma

\section{September.}

\section{Larvæ.}

(Some will have commenced hibernation.)

Aporia cratagi

Pieris brassica

rapa

napi

daplidice

Leucophasia sinapis

Colias hyale

edusa

Argynnis selene

euphrosyne

latona

aglaia

adippe

paphia
Melitea aurinia

cinxia

athalia

Vanessa atalanta

Limenitis sibylla

Apatura iris

Melanargia galatea

Erebia epiphron

athiops

Pararge egeria

megara

Satyrus semele

Epinephele ianira

tithonus 


\title{
I.ARVA-continued.
}

Epinephele hyperanthes

Canonympha typhon

$$
\text { pamphilus }
$$

Polyommatus phlaeas

Lycana astrarche

icarus

bellargus

corydon

Papilio machaon

Pieris brassica

$$
\begin{aligned}
& \text { rapa } \\
& \text { napi } \\
& \text { daplidice }
\end{aligned}
$$

Euchloë cardamines

Leucophasia sinapis

Vanessa C-album
Lycana argiolus minima

Nemeobius lucina

Syrichthus malve

Nisoniades tages

Hesperia thaumas sylvanus

Carterocephalus palamon

\section{Pupæ.}

\author{
Vanessa urtica \\ atalanta \\ Thecla rubi \\ Polyommatus phlceas \\ Lycana argiolus \\ Nemeobius lucina \\ Syrichthus malva
}

\section{Imagines.}

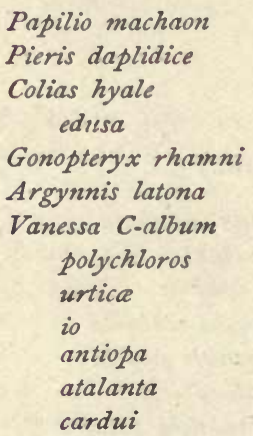

Danais erippus
Pararge egeria megara

Satyrus semele Epinephele tithonus Canonympha pamphilus Thecla betula

- Polyommatus phlceas Lycana batica icarus bellargus corydon argiolus Hesperia actaon (?) comma (?)

\section{October.}

The butterfly-collector's season is rapidly drawing to a close; but if the autumn is fine and warm he may still do a little further work. 


\section{Larvæ.}

Some of the following will be feeding, though most, if not all, that hibernate at this stage will be already laid up for the winter:

Aporia crategi

Pieris brassica

rapa

Leucophasia sinapis

Colias hyale

edusa

Argynnis selene

euphrosyne

latona

aglaia

adippe

paphia

Melitea aurinia

- cinxia

athalia

Limenitis sibylla

Apatura iris

Melanargia galatea

Erebia epiphron

athiops
Pararge egeria megara

Satyrus semele

Epinephele ianira

tithonus

hyperanthes

Canonympha typhon

pamphilus

Polyommatus phloeas

Lycana astrarche

icarus

bellargus

corydon

argiolus

minima

Nisoniades tages

Hesperia thaumas

sylvanus

Carterocephalus palamon

\section{Pupæ.}

The following may be sought for:

Papilio machaon

Pieris brassica

rapa

napi

daplidice

Leucophasia sinapis

Euchloë cardamines
Colias hyale edusa

Thecla rubi

Nemeobius lucina

Lycana argiolus

Syrichthus malva

\section{Imagines.}

Though the season is now so far advanced, it is possible that some of the species named may be found. 


\section{IMAGINES-continued.}

Colias hyale
edusa
Gonopteryx rhamni
Argynnis latona
Vanessa C-album
polychloros
urtica
io

Vanessa antiopa
atalanta
cardui
Thecla betula
Polyomisatus phloas
Lycana batica
icarus
bellargus

\section{November.}

Few signs of butterfly-life are apparent during this and the next three months. If the weather remains open one or two larvæ may not quite have ceased feeding, the most likely being perhaps, Pieris brassica, P. rapa, and Leucophasia sinapis, while an occasional imago of one of the species that hibernate at that stage may be found upon the wing. A list of the hibernating larvæ, pupæ, and imagines will be found at the commencement of this chapter under the heading January and February.

\section{December.}

All species are hibernating, as in January and February.

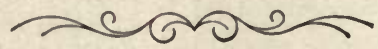




\section{GENERAL INDEX.}

A.

Adonis Blue, 193

"Animal," Definition of, I Antennæ of Butterflies and Moths, 3, 4

Anthocharis, 56 cardamines, 56

Anthriscus sylvestris, 57

Antiopa-year, I 12

Apatura, 125 iris, 125

Aporia, 39

cratægi, 40

cratægi extinct, 40

Argynnis, 74, 75

adippe, 85

adippe var. cleodoxa, 88

aglaia, 82

dia, 75

euphrosyne, 77

latona, 80

niobe, 75

paphia, 88

paphia var. valezina, 9I selene, 75

Arran Brown, 133

Arrangement of Butterflies in the Cabinet or Cases, 28

Arthropoda, 2

Azure Blue, 197
B.

Bath White, 53

Bedford Blue, 201

Black Hairstreak, 167, I 70

Black-veined Brown, I 30

White, 40

Blues, the, I8I

Breeding Butterflies, 12

Breeding-cages, 13

Brimstone Butterfly, ;o

Brown Argus, 188

Hairstreak, I 65

Browns, the, 132

Butterflies and Sunshine, 48 In the Cabinet, 24

Migrating, 48, 54

Butterfly, Definition of, 3

Butterfly-hunting, 7

Suitable Weather for, 7

Time of Day for, 7

Butterfly-net, 8

Butterfly's Place in Nature, I

Position among Animals,

Synopsis of, 5

C.

Cabbage White, 45

Calendar, Collector's, 224 
Camphor as a Mite Preventative, 25

Camberwell Beauty, I1 2

Carterocephalus, 22 I

palæmon, 222

paniscus, 222

Castle Eden Argus, 190

Chalk-hill Blue, 195

Chequered Skipper, 222

White, 53

Chortobius, 157

Chrysalis, Meaning of Term, Ior

Clifden Blue, 193

Clouded Saffron, 67

Sulphur, 65

Yellows, 63, 67

Cœnonympha, 157

davus, $15^{8}$

pamphilus, 160

typhon, 158

typhon var. philoxenus, 160

Colias, 63

typhon var. rothliebii, 160

Capricious Appearance of, 65 edusa, 67

edusa var. helice, 70

Hibernation of, 64

hyale, 65

Collecting-box, 12

Collector's Calendar, 224

January, 224

February, 224

March, 226

April, 227

May, 228

June, 230

July, 232

August, 234

September, 235

October, 236

November, 238

December, 238

Comma Butterfly, IO2

Common Blue, 19!

Copper, 179

Continental Large Copper, 176

Coppers, the, I 76

Cossus ligniperda, Trees affected by Larvæ of, visited by Antiopa, I13

Cyanide-bottle, how to make, II
D.

Danais, I 30 erippus, 130

Dark Green Fritillary, 82

Dark Hairstreak, 170

Dartford Blue, 193

Dingy Skipper, 4, 211

Distinction between Butterflies and Moths, 3

Drying Butterflies, 20

Duke of Burgundy Fritillary, 74, 205

Durham Argus, 190

\section{E.}

Edusa-year, 67

Egg of Butterfly, 6

Elm Butterfly, 105

Entomological pins, 17

Epinephele, 149

hero, 133

hyperanthes, 155

ianira, 149

tithonus, 153

Erebia, 136

athiops, 138

blandina, 138

cassiope, 136

epiphron, 136

ligea, 133

medea, 138

Erycinidx, 31, 205

Euchloë, 56.

cardamines, 56

cardamines, Second Brood, 57

F.

Families of British Butterflies, 29

Foes of Butterflies, 25

Folding Ring-net, 9

Food-plants, see Special Index

Fritillaries, the, 74

G.

Garden White, 45

Gatekeeper, 143, I 53 
Glanville Fritillary, 94

Goatmoth, Trees affected by Larvæ of, visited by Antiopa, I 13

Golden Copper, I 76

Gonopteryx, 70

cleopatra, 73

rhamni, 70

Grayling, 146

Grease, Cure of, 27

Greasy Fritillary, 92

Green Hairstreak, 174

Green-veined White, 5I

Grizzled Skipper, 209

\section{H.}

Hairstreaks, the, I64

Heath Fritillary, 96

Hesperia, 2 I 2

$$
\begin{aligned}
& \text { actæon, } 216 \\
& \text { comma, 220 } \\
& \text { linea, 213 } \\
& \text { lineola, 214 } \\
& \text { sylvanus, 218 } \\
& \text { thaumas, 213 }
\end{aligned}
$$

Hesperriidæ, 31, 208

Synopsis of Species in, 209

Heterocera, 3

Hibernation of Colias, 64

High Brown Fritillary, 85

Hipparchia, I 46

Holly Blue, 197

\section{I.}

Ichneumon Fly, 44, 92, 95

Imago of Butterfly, 7

Insect-cabinets, 24

Insect, Definition of, 2

Insecta, the, 3

Invertebrata, 2

Irregular Appearance of Vanessa cardui, I 18

K.

Killing a Butterfly, Method of, I I
L.

Large Blue, 203

Copper, 176

Copper, High Prices realised for, 176

Garden White, 45

Heath, I 53

Skipper, 218

Tortoiseshell, I05

White, 45

Larva of Butterfly, 6

Latona-year, 8I

Least Meadow Brown, 160

Lepidoptera, 3

Leucophasia, 6I

sinapis, $6 \mathrm{I}$

sinapis on the Wing, $6 \mathbf{I}$

Life-history of a Butterfly, 6

Limenitis, 12 I

sibylla, I 2 I

List of British Butterflies, 29

Little Blue, 20I

Localities for Butterflies in General, 8

Long-tailed Blue, 183

Lulworth Skipper, 216

Lycæna, I 8I

acis, 200

adonis, 193

ægon, 185

agestis, 188

alexis, I9I

alsus, 201

argiades, 185

argiolus, 197

arion, 203

astrarche, 188

astrarche var. artaxerxes, I 90

astrarche var. salmacis, 190

bætica, I 83

bellargus, 193

corydon, 195

icarus, I9I

idas, 188

medon, I 88

minima, 20 I

semiargus, 200

Synopsis of Species of, 182

Lycænidæ, 30 
M.

Marbled White, 133

Marsh Fritillary, $9^{2}$

Ringlet, 158

Mazarine Blue, 200

Meadow Brown, 149

Means of Defence in Larva, 36

Melanargia, 133 galatea, 133

Melitæa, 74, 75, 91

artemis, 92

athalia, 96

aurinia, 92

cinxia, 94

Mercuric Chloride as a Preservative against Mites and Mould, 27

Metamorphoses of Insects, 2, 6

Microgaster, 92

Migration of Argynnis latona, 80 Mites, 25

Mould, 26

Mountain Ringlet, 136

\section{N.}

Naphthalene, in preference to Camphor as a Preservative, 25

Nemeobius, 205.

lucina, 74,205

Net, Method of using, 10

New Small Skipper, 214

Niobe Fritillary, 75 .

Nisoniades, 2 I I

tages, 4,2 II

Northern Brown, 138

Note-making, I4

Scheme for, 15

Nymphalidx, 29, 74

\section{O.}

Orange-tip, $5^{6}$

\section{P.}

Painted Lady, I 8 Pale Clouded Yellow, 65
Pale-margined Specimens of Vanessa antiopa, 115

Papilio, 35 machaon, 35

podalirius, 35

Papilionidx, 29, 35

Pararge, I4I egeria, $14 \mathrm{I}$ megrera, 143

Parasites, 44

Peacock, 1 Io

Pea-pod Argus, 183

Pearl-bordered Fritillary, 77 Likeness Fritillary, 96

Pieris, 43

brassicæ, 45

daplidice, 53

metra, 49

napi, 5 I

rapre, 48

rapx in Canada, 48

Polyommatus, 176

dispar, 1,76

phloeas, 179

rutilus, 176

virgaurex, 176

Precautions to be observed in Drying Butterflies, 20

Preservation of Butterfly Colours, 24

Protective Resemblance, 57, 95, $100,134,148,150$

Pupa of Butterfly, 7

Purple Emperor, 125

Q.

Queen of Spain Fritillary, 8o

R.

Red Admiral, I1 6

Relaxing-box, 12

Relaxing Butterflies, 22

Resting Position of Butterfly, 4

Rhopalocera, 3

Ringlet, the, 155

Ringlets, the, I32

Rock-eyed Underwing, 146 
S.

Satyrus, 146

$$
\text { semele, } 146
$$

Scarce Swallow-tail, 36

Scientific Names, Advantage of, 28

Scotch Argus, ${ }^{3} 8$

Brown Argus, 190

Setting-boards, Types of, I6

Setting Butterflies, I6

Continental Method of, $I_{7}$

Setting-needles, I 8

Short-tailed Blue, I 85

"Silver-bug," Larva of Vanessa C-album, 103

Silver-spotted Skipper, 220

Silver-studded Blue, I 85

Silver-washed Fritillary, 88

Skipper, Method of Killing, 210

Skippers, 4, 208

Sleeping-places of Butterflies, 8

Small Copper, I79

Garden White, 48

Heath, I6o

Meadow Brown, I 53

Pearl-bordered Fritillary, 75

Ringlet, I 36, 158

Skipper, $2 \mathrm{I} 3$

Tortoiseshell, 107

White, 48

Speckled Wall Butterfly, I43

Wood Butterfly, I 4 I

Store-cases, 25

Swallow-tail, 36

Syrichthus, 209

alveolus, 209

malvæ, 209

malvæ var. lavateræ, 2 I I
T.

Terms descriptive of Larva, Pupa, and Imago, 31

Thanaos, $21 \mathrm{I}$

Thecla, 164

betulæ, 165

pruni, 170

quercus, 172

rubi, 174

W-album, 167

V.

Vanessa, 99

antiopa, II 2

atalanta, II 6

C-album, 102

cardui, I 8

cardui, Irregular Appearance of, II 8

io, 110

polychloros, 105

urticæ, 107

Vertebrata, 2

W.

Wall Butterfly, I43

Weaver's Fritillary, 75

White Admiral, I2 I

White-letter Hairstreak, 167

Wood Argus, I4I

Lady, I4 I

Ringlet, I55

White, 6I

$\mathrm{Y}$.

Yellow Variety of Pieris rapæ, 48 


\section{INDEX OF FOOD-PLANTS.}

A.

Alder Buckthorn, 197

Anthyllis vulneraria, 195, 202 Aspen, 105

B.

Barbarea præcox, $5 \mathrm{I}$ vulgaris, $5^{8}$

Betula alba, I1 3,165

Birch, I1 4,165

Bird's-foot, 186, 200 Trefoil, 62, 191, 195, 21 I, 220

Borage, $8 \mathrm{I}$

Borago officinalis, 8r

Brachypodium pinnatum, 217 sylvaticum, 213,222

Bramble, 174, 210

Brassica Napus, 5I

Broad-leaved Dock, I8o Plantain, 96

Bromus asper, 222

Broom, 174

Buckthorn, $7 \mathrm{I}$

$$
\text { C. }
$$

Cabbages, 45, 49

Cardamine pratensis, $5^{8}$
Carrot, Wild, 36

Charlock, $5^{8}$

Cherry, I05

Clover, 64, 195

Cock's-foot-grass, 218

Common Elm, I68

Fennel, 36

Furze, 186

Mallow, I 19

Nettle, IO2, 108, IIo, II4, II6, II9

Pear, 105

Rock Rose, 188

Sorrel, 180

Cornus sanguinea, 197

Cotton-grass, 158

Couch-grass, $2 \mathrm{I} 7,2 \mathrm{I} 8$

Cowslip, 206

Cowwheat, 98

Cratægus Oxyacantha, 40

Cuckoo-flower, $5^{8}$

Cytisus scoparius, 174

D.

Dactylis glomerata, 218

Daucus Carota, 36

Devil's-bit Scabious, 93

Digitalis purpurea, 93,98

Dog Violet, $76,78,81,82,85,90$ 
Dogwood, 197

Dyer's Weed, 174

E.

Early Winter Cress, 5I

Elm, 105

Eriophorum, 158

Erodium cicutarium, I 88

Erysimum cheiranthoides, $5^{8}$

Euonymus europæus, 197

F.

Fiddle-dock, I 80

Field-pea, 184

Field Scabious, 93

Flixweed, 55, $5^{8}$

Fœniculum vulgare, 36

Foxglove, 93, 98

Fragaria vesca, 210

G.

Garlic Mustard, 51, $5^{8}$

Genista tinctoria, I 74

Germander Speedwell, 98

Goat Willow, or Sallow, 128

Grasses, I 33

Great Periwinkle, I30

Water Dock, 177

H.

Hairy Brome-grass, 222

Woodrush, 218

Hawthorn, 40

Heath, 98

False Brome-grass, 217

Hedera Helix, 197

Hedge Mustard, 58

Helianthemum vulgare, 188

Hemlock Stork's-bill, I 88

Hippocrepis comosa, 193

Holcus lanatus, 213, 218

Holly, 197

Honeysuckle, 93, 122
Hop, 102

Trefoil, 63

Horseradish, 58

Horseshoe-vetch, 193

I.

Ilex Aquifolium, 197

Ivy, 197

K.

Kidney Vetch, 195, 202

Knautia arvensis, 93

L.

Lathyrus macrorhizus, 63

Lesser Periwinkle, ${ }^{1} 30$

London Rocket, $5^{8}$

Lonicera Periclymenum, 122

Lotus corniculatus, 62, 191, 195, 211,220 major, 185

Lucerne, 64

Luzula pilosa, 218

M.

Malva moschata, 2 Io sylvestris, II 9

Marsh Hog's Fennel, 36

Meadow Soft-grass, 213, 218

Medicago lupulina, 64 sativa, 64

Melampyrum pratense, 98

Mignonette (odorous), 49

Wild, 55

Musk Mallow, 210

N.

Narrow-leaved Bird's-foot Trefoil, I 85

Plantain, 93, 94, 96

Nasturtium officinale, 5 I

Nasturtiums, 45, 49 
Nerium, 130

Nonsuch, 64

\section{O.}

Oak, I 28, 172

Oleander, 130

Onobrychis sativa, 8I

Ononis arvensis, 191 spinosa, 191

Ornithopus perpusillus, I86, 220

P.

Pansy, Wild, $8 \mathrm{I}, 85$

Parietaria officinalis, I 16

Pellitory-of-the-Wall, 116

Penny Cress, 58

Peucedanum palustre, 36

Plantago lanceolata, 93, 94, 96 major, 96

Poplar, 128

Populus tremula, 105

Potentilla Fragariastrum, 210

Primrose, 206

Primula veris, 206 vulgaris, 206

Prunus cerasus, I0 5 spinosa, 40, 165, 170

Pyrus Aria, 105 communis, 105

\section{Q.}

Quercus Robur, 172

R.

Rape, 5I

Raspberry, 90, 210

Red Currant, 102

Reseda lutea, 55 luteola, 55

Rest-harrow, 19I

Rhamnus catharticus, 7 I Frangula, 71, 197

Rhynchospora alba, $15^{8}$

Ribes rubrum, 102
Rubus fruticosus, 174, 2 10 Idæus, 210

Rumex Acetosa, 180

Acetosella, 180

Hydrolapathum, 177

obtusifolius, I 80

pulcher, 180

S.

Sainfoin, 81

Salix, 105 alba, 113

Caprea, 128

Sallow, 105

Scabiosa succisa, 93

Sheep's Sorrel, 180

Sinapis arvensis, 58

Sisymbrium alliaria, $51,5^{8}$

Irio, $5^{8}$

officinale, 58

Sophia, 55,58

Slender False Brome-grass, 213 , 222

Sloe, 40, 165, 170

Small Nettle, 108

Spindle-tree, 197

Strawberry, Wild, 2 Io

Strawberry-leaved Potentilla, 210

Sweet Violet, 8I, 82, 85, 90

\section{T.}

Teucrium Scorodonia, 96

Thlaspi arvense, $5^{8}$

Thyme, Wild, 203

Thymus serpyllum, 203

Tower Mustard, $5^{8}$

Treacle Mustard, $5^{8}$

Trefoil, 195

Trifolium, 195 pratense, 64 procumbens, 63 repens, 64

Triticum, 215 repens, 217,218

Tropxolums, 45

Tuberous Bitter Vetch, 63 
Tufted Vetch, 62

Turritis glabra, $5^{8}$

\section{U.}

Ulex europæus, 186

Ulmus, 105 campestris, 168 montana, I68

Urtica dioica, 102, 108, I10, 114 , I16, II9 urens, 108

\section{V.}

Veronica Chamædrys, 98

Vicia Cracca, 62

Vinca major, ${ }^{1} 3^{\circ}$

minor, 130
Viola canina, $76,78,8 \mathrm{I}, 82,85$, 90 odorata, $81,82,85,90$ tricolor, $8 \mathrm{I}, 85$

W.

Watercress, $5 \mathrm{I}$

White Beak-rush, $15^{8}$ Beam-tree, 105

Willow, I 14

Wild Carrot, 36

Mignonette, 55

Pansy, 81, 85

Strawberry, 210

Thyme, 203

Willow, I05

Winter Cress, 58

Wood Sage, 96

Wych Elm, 168

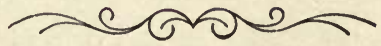


FOR

\section{Exchanging,}

\section{Selling,}

\section{Buying}

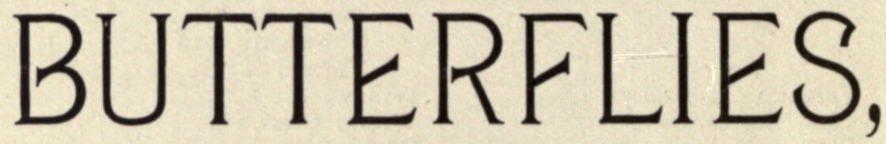

OR THEIR

PUP $\nRightarrow$ OR LARVÆ, OR

ENTOMOLOGICAL APPARATUS OF ANY KIND,

There is no better medium than

The JBazaar. The Exchange and SIlDart. ESTABLISHED 25 YEARS.

Price 2d., of all Newsagents. OFFICE:

170, STRAND, LONDON, W.C. 


\section{Catalogue

American Dainties, and How to Prepare Them. By an AMerican Ladr In paper, price 18., by post 18. $2 d$.

Ansler, Book of the All-Round. A Comprehensive Treatise on Angling in both Fresh and Salt Water. In Four Divisions as named below. By JOHN BICKERDYKE. With over 220 Engravings. In cloth, price 58. $6 d$., by post 58.10d.

Angling for Coarse Fish. Bottom Fishing, according to the Methods in use on the Thames, Trent, Norfolk Broads, and elsewhere. Illustrated. In paper, price 18., by post $18.2 d$. Angling for Pike. The most approved Methods of Fishing for Pike or Jack. New Edition, revised and enlarged. Profusely Illustrated. In paper, price 18., by post 18. 2d. ; cloth, 28. (uncut), by post $2 s .3 d$. Angling for Game Fish. The Various Methods of Fishing for Salmon; Moorland, Chalk-stream, and Thames Trout; Grayling and Char. Well Illustrated. In paper, price 18. $6 d$., by post 18. $9 d$.

Angling in Salt Water. Sea Fishing with Rod and Line, from the Shore, Piers, Jetties, Rocks, and from Boats; together with Some Acconnt of Hand-Lining. Over 50 Engravings. In paper, price 18., by post, 18. 2d. ; cloth, 2s. (uncut), by post 2s. 3d.

Angler, The Modern. A Practical Handbook on all Kinds of Angling. By "OTTER." Well illustrated. New Edition. In cloth, price 28.6d., by post $2 s$. $9 d$.

Aquaria, Book of. A Practical Guide to the Construction, Arrangement, and Management of Freshwater and Marine Aquaria; containing Fall Information as to the Plants, Weeds, Fish, Molluscs, Insects, \&c., How and Where to Obtain Them, and How to Keep Them in Health. Illustrated. By Rev. Gregory C. Bateman, A.K.C., and Reginald A. R. Bennett, B.A. In cloth gilt, price 58. $6 d$., by post $58.10 d$.

Equaria, Freshwater: Their Construction, Arrangement, Stocking, and Management. Fully illustrated. By REv. G. C. BATEMaN, A.K.C. In cloth gilt, price 3s. 6d., by post 38. 10 d.

Aquaria, Marine: Their Construction, Arrangement, and Management. Fully Illustrated. By R. A. R. BENNETT, B.A. In cloth gilt, price $28.6 d$., by post 2s. $9 d$.

Australia, Shall I Try? A Guide to the Australian Colonies for the Emigrant Settler and Business Man. With two Illustrations. By GEORGE LACON JAMES. In cloth gilt, price 38. 6d., by post 38. 10d.

Autograph Collecting: A Practical Manual for Amateurs and Historical Students, containing ample information on the Selection and Arrangement of Autographs, the Detection of Forged Specimens, \&c., \&c., to which are added numerous Facsimiles for Study and Reference, and an extensive Valuation Table of Autographs worth Collecting. By HENRY T. SCOTT, M.D., L.R.C.P., \&c. In leatherette gilt, price 78. 6d. nett, by post 78. 10d.

Bazaars and Fancy Fairs: Their Organization and Management. A Secretary's Vade Mecum. By JoHN MuIR. In paper, price 18., by post 1s. 2d.

Bees and Bee-Keeping: Scientific and Practical. By F. R. Cheshire, F.I.S., F.R.M.S., Lecturer on Apiculture at South Kensington. In two vols., cloth gilt, price 168., by post 168. $6 d$.

Vol. I., Scientific. A complete Treatise on the Anatomy and Physio. logy of the Hive Bee. In cloth gilt, price 78. 6d., by post 78. 10d.

Vol. Ir., Practical Management of Bees. An Exhaustive Treatise on Advanced Bee Culture. In cloth gilt, price 88. $6 d$., by post 88. 11 .

Bee-Keeping, Book of. A very practical and Complete Manual on the Proper Management of Bees, especially written for Beginners and Amateurs who have but a few Hives. Fully Illustrated. By W. B. WeBster, First-class Expert, B.B.K.A. In paper, price 18., by post 1 2d.; cloth, 18. 6d., by post 18. $8 d$. 
Begonia Culture, for Amateurs and Professionals. Containing Full Directions for the Successful Cultivation of the Begonia, under Glass and in the Open Air. Illustrated. By B. C. RAvenscrofT. In paper, price 18., by post 18. $2 d$.

Bent Iron Work: A Practical Manual of Instruction for Amateurs in the Art and Craft of Making and Ornamenting Light Articles in imitation of the beautiful Mediæval and Italian Wrought Iron Work. By F. J. ERSKINR. Illustrated. In paper, price 18., by post 18. $2 d$.

Birds, British, for the Cage and Ayiary. Illustrated. By DR. W. T. GRERNE.

IIn the press.

Boat Bullding and Salling, Practical. Containing Full Instructions for Designing and Building Punts, Skiffs, Canoes, Safling Boats, \&c. Particulars of the most suitable Sailing Boats and Yachts for Amateurs, and Instructions for their Proper Handling. Fully Illustrated with Designs and Working Diagrams. By ADRIAN NEISON, C.K., DixON KEMP, A.I.N.A., and G. CHRISTOPHER DAVIES. In one vol., cloth gilt, price 78. 6d., by post 78. $10 d$.

Boat Bullding for Amateurs, Practical. Containing Full Instructions for Designing and Building Punts, Skiffs, Canoes, Sailing Boats, \&c. Fully Illustrated with Working Diagrams. By ADRIAN NeISON, C.E. Second Edition, Revised and Enlarged by DIXON KEMP, Author of "Yacht Designing," "A Manual of Yacht and Boat Sailing," de. In cloth gilt, price 28. $6 d$. by post $28.9 d$.

Boat Salling for Amateurs, Practical. Containing Particulars of the most Suitable Sailing Bosts and Yachts for Amateurs, and Instructions for their Proper Handling, \&c. Ilustrated with numerous Diagrams. By G. Christopher Davizs. Second Edition, Rovised and Enlarged, and with several New Plans of Yachts. In cloth gilt, price 58., by post 58. 4 d.

Bookbinding for Amateurs : Being Descriptions of the various Tools and Appliances Required, and Minute Instructions for their Effective Use. By W. J. E. CRANE. Illustrated with 156 Engravings. In cloth gilt, price 2s. 6d., by post 2s. $9 d$.

Balb Culture, Popular. A Practical and Handy Guide to the Successful Cultivation of Bulbous Plants, both in the Open and under Glass. By W. D. DRURY. Fully Illustrated. In paper, price 1s., by post 18. $2 d$.

Bunkum Entertainments: A Collection of Original Laughable Skits on Conjuring, Physiognomy, Juggling, Performing Fleas, Waxworks, Panorama, Phrenology, Phonograph, Second Sight, Lightning Calculators, Ventriloquism, Spiritualism, \&c., to which are added Humorous Sketches, Whimsical Recitals, and Drawing-room Comedies. In cloth, price 2s. 6d., by post 2s. 9d.

Butterfles, The Book of British: A Practical Manual for Collectory and Naturalists. Splendidly Illustrated throughout with very accurate Engravings of the Caterpillars, Chrysalids, and Butterflies, both upper and under sides, from drawings by the Author or direct from Nature. By W. J. LuCas, B.A. Price 38. 6d., by post $38.9 d$.

Butterfiy and Moth Collecting: Where to Search, and What to Do. By G. E. SIMMS. Ilustrated. In paper, price 18., by post 18. $2 d$.

Cabinet Making for Amateurs. Being clear Directions How to Construct many Useful Articles, such as Brackets, Sideboard, Tables, Cupboards, and other Furniture. Illustrated. In cloth gilt, price $28.6 d$., by post $28.9 d$.

Cactus Culture for Amateurs: Being Descriptions of the various Cactuses grown in this country; with Full and Practical Instructions for their Success. ful Cultivation. By W. WArson, Assistant Curator of the Royal Botanic Gardens, Kew. Profusely Illustrated. In cloth, gilt, price 58. nett, by post 58. $4 d$.

Cage Birds, Diseases of: Their Causes, Symptoms, and Treatment. A Handbook for everyone who keeps a Bird. By DR. W. T. GREENE, F.Z.S. In paper, price 18., by post 18. 2d.

Canary Book. The Breeding, Rearing, and Management of all Varieties of Canaries and Canary Mules, and all other matters connected with this Fancy. By ROBERT L. Wallace. Third Edition. In cloth gilt, price 58., by post 58. 4d. ; with COLOURED PLATES, 68. 6d., by post 68. $10 d$.

General Management of Canaries. Cages and Cage-making, Breeding, Managing, Mule Breeding, Diseases and their Treatment, Moulting, Pests, \&c. Ulustrated. In cloth, price 2s. 6d., by post 2s. $9 d$.

Exhibition Canaries. Full Particulars of all the different Varieties, their Points of Excellence, Preparing Birds for Exhibition, Format on and Management of Canary Societies and Exhibitions. IUustrated. In cloth, price $28.6 d$. by post $28.9 d$. 
Cane Basket Work: A Practical Manual on Weaving Useful and Fancy Baskets By ANNIE FIRTH. Illustrated. In cloth gilt, price 18. 6d., by post 18.8d.

Card Conjuring: Being Tricks with Cards, and How to Perform Them By PROF. Ellis STANYON. Illustrated, and in Coloured Wrapper. Price $1 s$. by post $18.2 d$

Card Tricks, Book of, for Drawing-room and Stage Entertainments by Amateurs; with an exposure of Tricks as practised by Card Sharpers and Swindlers. Numerous Illustrations. By PROF. R. KUNARD. In illustrated urapper, price $2 s .6 d$., by post $2 s .9 d$.

Carnation Culture, for Amateurs. The Culture of Carnations and Picotees of all Classes in the Open Ground and in Pots. Illustrated. By B. C. Ravens. CROFT. In paper, price 18., by post 18. $2 d$.

Cats, Domestic or Fancy : A Practical Treatise on their Antiquity, Domestication, Varieties, Breeding, Management, Diseases and Remedies, Exhibition and Judging. By JOHN J ENNINGS. Illustrated. In cloth, price $28.6 d$., by post 28. $9 d$.

Chrysanthemum Culture, for Amateurs and Professionals. Containing Full Directions for the Successful Cultivation of the Chrysanthemum for Exhibition and the Market. By B. C. RAvenscroft. New Edition. Illustrated. In paper, price 18., by post 1s. $2 d$.

Chrysanthemum, The Show, and Its Cultivation. By C. SCOTT, of the Sheffield Chrysanthemum Society. In paper, price $6 d$., by post $7 d$.

Coins, a Guide to English Pattern, in Gold, Silver, Copper, and Pewter, from Edward I. to Victoria, with their Value. By the REV. G. F. CrowTHER, M.A. Illustrated. In silver cloth, with gilt facsimiles of Coins, price 5s., by post $58.3 d$.

Coins of Great Britain and Ireland, a Guide to the, in Gold, Silver, and Copper, from the Earliest Period to the Present Time, with their Value. By the late Colonel W. Stewart Thorburn. Third Edition. Revised and Enlarged, by H. A. GRUEBER, F.S.A. Illustrated. In cloth gilt, price 108. $6 d$ net, by post 108. $10 d$.

Cold Meat Cookery. A Handy Guide to making really tasty and much appreciated Dishes from Cold Meat. By MRS. J. E. DAvidson. In paper, price 1s., by post 1s. $2 d$.

Collie, The. Its History, Points, and Breeding. By HugH DalzIEL, Illustrated with Coloured Frontispiece and Plates. In paper, price 18., by post 18. $2 d$. ; cloth, 28 ., by post $283 \mathrm{~d}$.

Collie Stud Book. Edited by Hugh Dalziel. Price 38. 6d. each, by post 38. $9 d$. each.

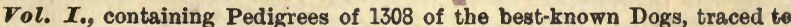
their most remote known ancestors; Show Record to Feb., 1890, \&c.

Vol. II. Pedigrees of 795 Dogs, Show Record, \&c.

Vol. III. Pedigrees of 786 Dogs, Show Record, \&c.

Columbarium, Moore's. Reprinted Verbatim from the originial Edition of 1735, with a Brief Notice of the Author. By W. B. TEGETMEIER, F.Z.S., Member of the British Ornithologists' Union. Price 18., by post 1s. $2 d$.

Conjuring, Book of Modern. A Practical Guide to Drawing-room and Stage Magic for Amateurs. By Professor R. KUNARD. Illustrated. In illustrated wrapper, price 2s. 6d., by post $2 s .9 d$.

Conjuring for Amateurs. A Practical Handbook on How to Perform a Number of Amusing Tricks. By PROF. ELLIS STANYON. In paper, price 18., by post 18, $2 d$.

Cookery, The Encyclopredia of Practical. A complete Dictionary of all pertaining to the Art of Cookery and Table Service. Edited by THEo. Francrs GARRETT, assisted by eminent Chefs de Cuisine and Confectioners. Profusely Illustrated with Colonred Plates and Engravings by HaROLD FurNess, Gee. CRUIKShank, W. MUNN ANDREW, and others. In 2 vols., demy 4to., half bound, cushion edges, $£ 3$ 3s.; carriage free, $£ 358$.

Cookery for Amateurs; or, French Dishes for English Homes of all Classes. Includes Simple Cookery, Middle-class Cookery, Superior Cookery, Cookery for Invalids, and Breakfast and Luncheon Cookery. By MADAMK VALÉRIE. Second Edition. In paper, price 18., by post 18. $2 d$.

Cucumber Culture for Amateurs. Including also Melons, Vegetable Marrows, and Gourds. Illustrated. By W. J. MAY. In paper, price is by post 18. $2 d$. 
Cyclist's Route Map of England and Wales. Shows clearly all the Main, and most of the Cross, Roads, Railroads, and the Distances between the Chiof Towns, as well as the Mileage from London. In addition to this, Routes of Thirty of the Most Interesting Tours are printed in red. Fourth Edition, thoroughly revised. The map is printed on specially prepared rellum paper, and is the fullest, handiest, and best up-to-date tourist's map in the market. In eloth, price 18., by post 18. $2 d$.

Designing, Harmonlo and Keyboard. Explaining a System whereby an endless Variety of Most Beauciful Designs suited to numberless Manufactures may be obtained by Unskilled Persons from any Printed Yusic. Illustrated by Numerous Explanstory Diagrams and Illustrative Examples. By C. H. WILkINson. Demy 4to, price £2 28 , nett.

Dogs, Breaking and Training: Being Concise Directions for the proper education of Dogs, both for the Field and for Companions. Second Edition. By "PATafinder." With Chapters by Hü Dalzixi Illustrated. In cloth gilt, price 6s. 6d., by post 6 s. $10 d$.

Dogs, British, Ancient and Modern: Their Varieties, History, and Characteristics. By Huar DALZIEL, assisted by Eminent Fanciers. Beautifully Illustrated with COLOURED PLATES and full-page Engravings of Dogs of the Day, with numerous smaller illustrations in the text. This is the fullest work on the various breeds of dogs kept in England. In three volumes, demy 800 , eloth gilt, price 10s. $6 d$. each, by post 118 . each.

Vol. I. Dogs Used in Field Sports.

Vol. II. Dogs Useful to Man in other Work than Field Sports; Hovse and Toy Dogs.

Vol. III. Practical Kénnel Management: A Complete Treatise on all Matters relating to the Proper Management of Dogs whether kept for the Show Bench, for the Field, or for Companions.

Dogs, Diseases of: Their Causes, Symptoms, and Treatment; Modes of Administering Medicines; Treatment in cases of Poisoning, \&c. For the use of Amateurs. By HuGH DALzieL. Fourth Edition. Entirely Re-written and brought up to Date. In paper, price 18., by post 18. $2 d$. ; in cloth gilt, 2s., by post $28.3 d$.

Dos-Keeping, Popular: Being a Handy Guide to the General Managemen and Training of all Kinds of Dogs for Companions and Pets. By J. Maxrez. Illustrated. In paper, price 1s., by post $18.2 d$.

Fngravings and their Yalue. Containing a Dictionary of all the Greatest Engravers and their Works. By J. H. SLATER. New Kdition, Revised and brought up to date, with latest Prices at Auction. In cloth gilt, price 158. nett, by post, 158. $5 d$.

Entertainments, Amateur, for Charitable and other objects: How to Organise and Work them with Protit and Success By ROBERT GANTHONY In coloured cover. price 18., by post 1s. $2 d$.

Fancy Work Series, Artistic. A Series of Illustrated Manuals on Artistic and Popular Fancy Work of various kinds. Fach number is complete in itself, and issued at the uniform price of $6 d$., by post $7 d$. Now ready-(1) MaCramk Lace (Second Edítion); (2) Patchwork ; (3) Tatring ; (4) CRewei WORK; (5) APPLIQUE ; (6) FANCT NETTING.

Feathered Friends, Old and New. Being the Experience of many years Observation of the Habits of British and Foreign Cage Birds. By DR. W. T. GRRENE Illustrated. In cloth gilt, price 58., by post $58.4 d$.

Ferns, The Book of Cholce: for the Garden, Conservatory, and Store. Describing the best and most striking Ferns and Selaginellas, and giving explicit directions for their Cultivation, the formation of Rockeries, the arrangement of Ferneries, \&c. By GEORGR SCHNEIDER. With numerous Coloured Plates and other Illustrations. In 3 vols., large post 4 to. Cloth gilt, price $£ 33$. nett, by post $£ 358$.

Ferns, Choice British. Descriptive of the most beautiful Variations from the common forms, and their Culture. By C. T. DRUERY, F.I.S. Very accurate PLATES, and other Illustrations. In cloth gilt, price $28.6 d .$, by post $28.9 d$.

Ferrets and Ferreting. Containing Instructions for the Breeding, Manage. ment, and Working of Ferrets. Second Edition, Re-written and greatly Enlarged. Illustrated. In paper, price $6 d$., by post $7 d$.

Fertllity of Eggs Certificate. These are Forms of Guarantee given by the Sellers to the Buyers of Eggs for Hatching, undertaking to refund value of any unfertile eggs, or to replace them with good ones. Very valuable to sellers of eegs, as they induce purchases. In books, with counterfoils. price $6 d$, by nost $7 d$. 
Firework Making for Amateurs. A complete, accurate, and easily. understood work on Making simple and High-class Fireworks. By DR. W. H. BROWNE, M.A. In coloured wrapper, price $2 s 6 d$, by post $28.9 d$.

Fisherman, The Practical. Jealing with the Natural History, the Legendary Lore, the Capture of British Fresh-Water Fish, and Tackle and Tackle-making. By J. H. KeENE. In cloth gilt, price 7s. 6d., by post 7s. 10d.

Fish Flesh, and FowI When in Season, How to Select, Cook, and Serve. BY MARY BARRETT BROWN. In coloured vrapper, price 18., by post 18. 3d.

Forelgn Birds, Fayourlte, for Cages and Aviaries. How to Keep them in Health. Fully Illustrated. By W. T. GREENE, M.A., M.D., F.Z.S., \&c. In cloth, price $28.6 \bar{d}$., by post $2 s .9 d$.

Fox Terrler, The. Its History, Points, Breeding, Rearing, Preparing for Exhibition, and Coursing. By HUGH DALzIEL Illustrated with Coloured Frontispiece and Plates. In paper, price 18., by post 18. $2 d$.; cloth, 2s., by post 2s. $3 d$.

Fox Terriex Stud Book. Edited by HuGH DAlzIEL. Price 38.6d. each, by post 3s. $9 d$. each.

Vol. I., containing Pedigrees of over 1400 of the best-known Dogs, traced to their most remote known ancestors.

Vol. II. Pedigrees of 1544 Dogs, Show Record, \&c.

Vol. III. Pedigrees of 1214 Dogs, Show Record, \&c.

Vol. IV. Pedigrees of 1168 Dogs, show Record, \&c.

Vol. $\boldsymbol{V}$. Pedigrees of 1662 Dogs, Show Record, \&c.

Fretwork and Marquetry. A Practical Manual of Instructions in the Art of Fret-cutting and Marquetry Work. Profusely Illustrated. By D. DENNing. In cloth, price $2 s .6 d$., by post $2 s .9 d$.

Friesland Meres, $\mathbb{A}$ Cruise on the. By Ernest R. Suffling. Illustrated. In paper, price 1s., by post 1s. $2 d$.

Fruit Culture for Amateurs. By S. T. WRIGHT. With Chapters on Insect and other Fruit Pests by W. D. DRURY. Illustrated. In cloth gilt, price $38.6 d$. , by post $38.9 d$.

Game Preserying, Practical. Containing the fullest Directions for Rearing and Preserving both Winged and Ground Game, and Destroying Vermin; with other Information of Value to the Game Preserver. By W. Carnegis. Illustrated. In cloth gilt, demy $8 v 0$, price 21 s., by post $218.5 \mathrm{~d}$.

Games, the Book of a Hundred. By MARY WHITE. These Games are for Adults, and will be found extremely serviceable for Parlour Entertainment. They are Clearly Explained, are Ingenlous, Clever, Amusing, and exceedingly Novel. In stiff boards, price $2 s$. $6 d$. by post $28.9 d$.

Gardening, Dictionary of. A Practical Encyclopædia of Horticulture, for Amateurs and Professionals. Illustrated with 2440 Engravings. Edited by G. Nicholson, Curator of the Royal Botanic Gardens, Kew ; assisted by Prof. Trail, M.D., Rev. P. W. Myles, B.A., F.L.S., W. Watson, J. Garrett, and other Specialists. In 4 vols., large post 4 to. In cloth gilt, price $£ 3$, by post $£ 328$.

Gardening in Egy pt. A Handbook of Gardening for Lower Egypt. With a Calendar of Work for the different Months of the Year. By WALTER DRAPER. In cloth, price $3 s .6 d$., by post $38.9 d$.

Gardening, Home. A Manual for the Amateur, Containing Instructions for the Laying Out, Stocking, Cultivation, and Management of Small GardensFlower, Fruit, and Vegetable. By W. D. DRURY, F.R.H.S. Illustrated. In coloured wrapper, price 18., by post 18. $2 d$.

Goat, Book of the. Containing Full Particulars of the Various Breeds of Goats, and their Protitable Management. With many Plates. By H. STEPHeN Holmes PEGLER. Third Edition, with Engravings and Coloured Frontispiece. In cloth gilt, price 48. 6d., by post $48.10 d$.

Goat-Keeping for A mateurs: Being the Practical Management of Goats for Milking Purposes. Abridged from "The Book of the Goat." Illustrated. In paper, price 18., by post 18.2d.

Grape Growing for A mateurs. A Thoroughly Practical Book on Successful Vine Culture. By E. Moly NEUX. Illustrated. In paper, price 18., by post 18. $2 d$.

Greenhouse Management for Amateurs. The Best Greenhouses and Frames, and How to Build and Heat them, Illustrated Descriptions of the most suitable Plants, with general and Special Cultural Directions, and all necessary information for the Guidance of the Amatear. Second Edition, Revised and Enlarged. Magniflcently Illustrated. By W. J. MAY. In cloth gilt, price $5 \varepsilon_{.}$, by post $58.4 d$.

Greyhound, The : Its History, Points, Breeding, Rearing, Training, and Running. By Hugh Dalziel. With Coloured Frontispiece. In cloth gilt, demy 8v0., price $28.6 d$., by post $28.9 d$. 
Guinea Pig, The, for Food, Fur, and Fancy. Its Varieties and its Management. By C. CUMBerland, F.7.S. Illustrated. In coloured wrapper, price 18., by post 18. $2 d$. In cloth gilt, with coloured frontispiece, price 28. 6d., by post 28. $9 d$.

Handwriting, Character Indicated by. With Illustrations in Support of the Theories advanced, taken from Autograph Letters, of Statesmen, Lawyers, Soldiers, Ecclesiastics, Authors, Poets, Musicians, Actors, and the persons. Second Edition. By R. BAUGBAN, In cloth gilt, yriee $286 d$., by post 2s. $9 d$.

Hardy Perennials and Old-fashioned Garden Flowers. Descriptions, alphabetically arranged, of the most desirable Plants for Borders, Rockeries, and Shrubberies, including Foliage as well as Flowering Plants. By J. WooD. Profusely Illustrated. In cloth, yrice 38. 6d., by post 38.9 9 .

Hawk Moths, Book of British. A Popular and Practical Manual for all Lepidopterists. Copiously illustrated in black and white from the Author's own exquisite Drawings from Nature. By W. J. LuCAs, B.A. In cloth, price 38. 6 d., by post 3s. $9 d$.

Home Medicine and Surgery : A Dictionary of Diseases and Accidents, and their proper Home Treatment. For Family Use. By W. J. MaCkENzie, M.D. Illustrated. In cloth, price $28.6 d$., by post $28,9 d$.

Horse-Keeper, The Practical. By George Fleming, C.B., LL.D., F.R.C.V.S. late Principal Veterinary Surgeon to the British Army, and Kx-President of the Royal College of Veterinary Surgeons. In cloth, price 3. $6 d$., by post 3. $10 d$.

Horse-Keeping for Amateurs. A Practical Manual on the Management of Horses, for the guidance of those who keep one or two for their personal use. By FoX RUSSELL. In paper, price 18., by post 18. $2 d$. ; cloth 28., by post $28.3 d$.

Horses, Diseases of: Their Causes, Symptoms, and Treatment. For the use of Amateurs. By HUGH DALZIEL. / In paper, price 18., by post 18. 2d. ; cloth 28 , by post 28 . $3 d$.

Incubators and their Management. By J. H. Sutcliffe. New Edition, Rovised and Enlarged. Illustrated. In paper, price 18., by post 18. $2 d$.

Inland Watering Places. A Description of the Spas of Great Britain and Ireland, their Mineral Waters, and their Medicinal Value, and the attractions which they offer to Invalids and other Visitors. Profusely lllustrated. A Companion Volume to "Seaside Watering Places," In cloth, price 2s. 6d., by post 2s. $10 d$.

Jack All Alone. Being a Collection of Descriptive Yachting Reminiscences. By Frank CowPER, B.A., Author of "Sailing Tours." Illustrated. In cloth gilt, price 38. 6d., by post 38. $10 d$.

Journalism, Practical: How to Enter Thereon and Succeed. A book for all who think of "writing for the Press." By JoHN DAwson. In cloth gilt, price 28. $6 d .$, by post 28.92 .

Laying Hens, How to Keep and to Rear Chickens in Large or Small Numbers, in Absolute Confinement, with Perfect Success. By MAJOR G. F. MORANT. In paper, price $6 d$., by post $7 d$.

Library Manual, The. A Guide to the Formation of a Library, and the Values of Rare and Standard Books. By J. H. Slater, Barrister-at-Law. Third Edition. Rovised and Greatly Enlarged. In cloth gilt, price 7s. $6 d$. nett, by post 78. 10d.

Magic Lanterns, Modern. A Guide to the Management of the Optical Lantern, for the Use of Entertainers, Lecturers, Photograpers, Teachers, and others. By R. Chinn BAYLEY. In paper, price 18., by post 18.2d.

Mice, Fancy: Their Varieties, Management, and Breeding. Third Edition, with additional matter and Illustrations. In coloured wrapper representing different varieties, price 18., by post 18. $2 d$.

Millinery, Handbook of. A Practical Manual of Instruction for Ladies. Illustrated. By MME. Roske, Court Milliner, Principal of the School of Millinery. In paper, price 18., by post 18. 2d.

Model Yachts and Boats: Their Designing, Making, and Sailing. Illustrated with 118 Designs and Working Diagrams. By J. DU V. Grosvenor. In leatherette, price 58. , by post 5 s. $3 d$.

Monkeys, Pet, and How to Manage Them. Illustrated. BJ ARTHUR Patrera SON. In cloth gilt, price $28.6 d$., by post 28 .' $9 d$. 
Mountalneering, Welsh. A Complete and Handy Guide to all the Best Roads and Bye-Paths by which the Tourist should Ascend the Welsh Mountains. By A. W. PERRY. With numerous Maps. In cloth gilt, price 2s. $6 d$., by post $2 s$. $9 d$.

Mushroom Culture for Amateurs. With Full Directionz for Successful Growth in Houses, Sheds, Cellars, and Pots, on Shelves, and Out of Doors. Illustrated. By W. J. MAY. In paper, price 1s., by post 18. $2 d$.

Natural History Sketches among the Carnivora-Wild and Domesticated; with Observations on their Habits and Mental Faculties. By ARTHUR Nicols, F.G.S., F.R.G.S. Illustrated. In cloth gilt, price 28 . 6d., by post 28. $9 d$.

Naturalist's Directory, The, for 1898 (fourth year of issue). Invaluable to all Students and Collectors. In paper, price 18., by post 18. Id.

Needlework, Dictionary of. An Encyclopredia of Artistic, Plain, and Fancy Needlework; Plain, practical, complete, and magnificently Illustrated. By S. F. A. CAULFEILD and B. C. SAWARD. In demy 4to, 528pp, 829 Illustrations, extra cloth gilt, plain edges, cushioned bevelled boards, price 218. nett, by post 218.9 d.; with COLOURED PLATES, elegant satin brocade cloth binding, and coloured edges, 31s. $6 d$. nett, by post 328 .

Orchids: Their Culture and Management, with Descriptions of all the Kinds in General Cultivation. Illustrated by Coloured Plates and Engravings. By W. WAtson, Assistant-Curator, Royal Botanic Gardens, Kew; Assisted by W. BEan, Foreman, Royal Gardens, Kew. Second Edition, Revised and with Extra Plates. In cloth gilt and gilt edges, price $£ 1$ 1s. nett, by post £1 1s. $6 d$.

Painters and Their Works. A Work of the Greatest Value to Collectors and such as are interested in the Art, as it gives, besides Biographical Sketches of all the Artists of Repute (not now living) from the 13th Century to the present date, the Market Value of the Principal Works Painted by Them, with Full Descriptions of Same. In 3 vols., cloth, price 15s. nett per vol., by post 158. $5 d$., or 378.6 . nett the set of 3 , by post $388.3 d$.

Palntings, Decoratiye. A practical Handbook on Painting and Etching npon Textiles, Pottery, Porcelain, Paper, Vellum, Leather, Glass, Wood, Stone, Metals, and Plaster. for the Decoration of our Homes. By B. C. SAWARD. In cloth gilt, price $38.6 d$., by post $38.9 d$.

Parcel Post Dispatch Book (registered). An invaluable book for all who send parcels by post. Provides Address Labels, Certificate of Posting, and Record of Parcels Dispatched. By the use of this book parcels are insured against loss or damage to the extent of £2. Authorised by the Post Office. Price 18., by post 18. 2d., for 100 parcels; larger sizes if required.

Parrakeets, Popular. How to Keep and Breed Them. By DR. W. T. GREENE, M.D., M.A., F.Z.S., \&c. In coloured wrapper, price 1s., by post, 1s. $2 d$.

Parrot, The Grey, and How to Treat it. By W. T. GRene, M.D., M.A., F.Z.S., \&c. In coloured wrapper, price 18., by post 18. $2 d$.

Parrots, the Speaking. The Art of Keeping and Breeding the principal Talking Parrots in Confinement. By DR. KARL RUSS. Illustrated with COLOURED PLATES and Engravings. In cloth pilt, price 58. , by post 5 s. $4 d$.

Patience, Games of, for one or more Players. How to Play 142 different Games of Patience. By M. Whitmore Jones. Illustrated. Series I., 39 games; Series II., 34 games; Series III., 33 games; Series IV., 37 games. Each 18., by post 18. 2d. The four bound together in cloth gilt, price 5s., by post $58.4 d$.

Perspective, The Essentials of. With numerous Illustrations drawn by the Author. By L. W. MILLER, Principal of the School of Industrial Art of the Pennsylvania Museum, Philadelphia. Price 68. $6 d .$, by post $68.10 d$.

Pheasant-Keeping for Amateurs. A Practical Handbook on the Breeding, Rearing, and General Management of Fancy Pheasants in Confinement. By GEO. HORNE. Fully Illustrated. In cloth gilt, price 38.6d., by post 3s. 9d.

Photographic Printing Processes, Popular. A Practical Guide to Printing with Gelatino-Chloride, Artigue, Platinotype, Carbon, Bromide, Collodio-Chloride, Bichromated Gum, and other Sensitised Papers. Illustrated. By H. Maclean, F.R.P.S. Price 2s. $6 d$, by post 2s. $10 d$.

Photography (Modern) for Amateurs. New and Revised Edition. By J. EATON FEARN. In paper, price 18., by post 18. $2 d$.

Pianofortes, Tuning and Repairing. The Amateur's Guide to the Practical Management of a Piano without the intervention of a Professional. By Charles BabBington. In paper, price $6 d$., by post $6 \frac{1}{2} d$. 
Plcture-Frame Making for Amateurs. Being Practical Instruction: in the Muking of various kinds of Frames for Paintings, Drawings, Photographs, and Engravings. Illustrated. By the REv. J. LUKIN. In paper, jrice 18., by post is $2 d$.

Pig, Book of the. The Selection, Breeding, Feeding, and Management of the Pig; the Treatment of its Diseases; the Curing and Preserving of Hams, Bacon, and other Pork Foods; and other information appertaining to Pork Farming. By Professor James LoNG. Fully Illustrated with Portraits of Prize Pigs, Plans of Model Piggeries, \&c. In cloth gilt, price 108. 6d., by post 10s. 11d.

Plg-Keeping, Practical: A Manual for Amateur, based on personal Experience in Breeding, Feeding, and Fattening; also in Buying and Selling Piga at Market Prices.' By R. D. GARRATT. In paper, price 1s., by post 1s. $2 d$.

Pigeons, Fancy. Containing full Directions for the Breeding and Manage. ment of Fancy Pigeons, and Descriptions of every known Variety, together with all other information of interest or nse to Pigeon Fanciers. Third Edition. 18 COLOURED PLATES, and 22 other full-page Illustrations. By J. C. LYELL. In cloth gilt, price 10s. 6d., by post 108. $10 d$.

Pigeon-Keeping for Amateurs. A Complete Guide to the Amateur Breeder of Domestic and Fancy Pigeons. By J. C. LYELL. Illustrated. In cloth, price 2s. $6 d$., by post 2s. 9d.

Polishes and Stains for Wood: A Complete Guide to Polishing Wood. work, with Directions for Staining, and Full Information for Making the Stains, Polishes, \&c., in the simplest and most satisfactory manner. By David DenNing. In paper, 18., by post 18. $2 d$.

Pool, Games of. Describing Varions English and American Pool Games, and giving the Rules in full. Illustrated In paper, price 18., by post 18. 2 d.

Postage Stamps, and their Collection. A Practical Handbook for Collectors of Postal Stamps, Envelopes, Wrappers, and Cards. By OLIVER FirTi, Member of the Philatelic Societies of Lonion, Leeds, and Bradford. Profusely Illustrated. In cloth gilt, price $38.6 d .$, by post $38.10 d$.

Postage Stamps of Europe, The Adhesive: A Practical Guide to their Collection, Identitication, and Classidcation. Especially designed for the use of those commencing the Study. By W. A. S. Westoby. Beautifully Illustrated. In Parts, 18. each, by post 18. $2 d$.

Postmarks, History of British. With 350 Illustrations and a List of Numbers used in Obliterations. By J. H. DANIELS. In cloth, price $2 s_{\bullet} 6 d$, by post $28.9 d$.

Pottery and Porcelain, English. A Guide for Collectors. Handsomely Illustrated with Engravings of Specimen Pieces and the Marks used by the different Makers. New Edition, Revised and Enlarged. By the REV. E. A. DOWNMAN. In cloth gilt, price 58, by post 58. $3 d$.

Poultry-Farming, Profitable. Describing in Detail the Methods that Give the Best Results, and pointing out the Mistakes to be Aroided. Illustrated. By J. H. Sutcliffe. Price 18., by post 18. $2 d$.

Poultry-Keeping, Popular. A Practical and Complete Guide to Breeding and Keeping Poultry for Eggs or for the Table. By F. A. MAckevzie. Illus. trated. In paper, price 18., by post 18. $2 d$.

Poultry and Pigeon Diseases Their Causes, Symptoms, and Treatment. A Practical Manual for all Fanciers. By Quintin Craig and James LYell. In paper, price 18., by post 18. $2 d$.

Poultry for Prizes and Profit. Contains: Breeding Poultry for Prizes, Exhibition Poultry and Management of the Poultry Yarc. Handsomely Illus. trated. Second Edition. By PROF. JAMES LONG. In cloth gilt, price $\mathrm{Zs.} \mathrm{6d.,}$ by post $28.10 d$.

Rabbit, Book of The. A Complete Work on Breeding and Rearing all Varieties of Fancy Rabbits, giving their History, Variations, Uses, Points, Selection, Mating, Management, \&c., \&c. SECOND EDITION, Edited by KEMPSTER W. KNIGHT. Illustrated with Coloured and other Plates. In clpth gilt, price 10s. 6d., by post 108. 11d.

Rabblts, Diseases of: Their Causes, Symptoms, and Cure. With a Chapter on THE DISEASES OF CAviEs. Reprinted from "The Book of the Rabbit" and "The Guinea Pig for Food, Fur and Fancy." In paper, price 18., by post 1s. 2d. 
Rabbits for Prizes and Profit. The Proper Management of Fancy Rabbits in Health and Disease, for Pets or the Market, and Descriptions of every known Variety, with Instructions for Breeding Good Specimens. Illustrated. By Charles Rayson. In cloth gilt, price 28. 6d., by post 28. 9d. Also in Sections, as follows:

General Management of Rabbits. Including Hutches, Breeding, Feeding, Diseases and their Treatment, Rabbit Courts, \&c. Fully Illustrated. In paper, price 1s., by post 1s. $2 d$.

Exhibition Rabbits. Being descriptions of all Varieties of Fancy Rabbits, their Points of Excellence, and how to obtain them. Illustrated. In paper, price 18., by post 18. $2 d$

Road Charts (Registered). For Army Men, Volunteers, Cyclists, and other Road Users. By S. W. H. DIXON and A. B. H. CLERKE. No. 1.-London to Brighton. Price $2 d$., by post $2 \frac{1}{2} d$.

Roses for Amateurg. A Practical Guide to the Selection and Cultivation of the best Roses. Illustrated. By the Rev. J. HONYwOod D'OMBrarn, Hon. Sec. Nat. Rose Soc. In paper, price 1s., by post 18. $2 d$.

Salling Guide to the Solent and Poole Harbour, with Practical Hints as to Living and Cooking on, and Working a Small Yacht. By LIEUT.-CoL. T. G. CUTHELL. Illustrated with Coloured Charts. In cloth gilt, price $28.6 d$., by post 28 . $\& d$.

Salling Tours. The Yachtman's Guide to the Cruising Waters of the English and Adjacent Coasts. With Descriptions of every Creek, Harbour, and Roadstead on the Course. With numerous Charts printed in Colours, showing Deep water, Shoals, and Sands exposed at low water, with sounding. In Croun $8 v o$. , cloth gilt. By Frank CoWPER, B.A.

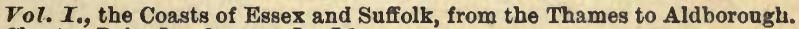
Six Charts. Price 58., by post 58 . $3 d$.

Vol. II. The South Coast, from the Thames to the Scilly Islands, twentyfive Charts. Price 78. 6d., by post 78. $10 d$.

Vol. III. The Coast of Brittany, from I'Abervrach to St. Nazaire, and an Account of the Loire. Twelve Charts. Price 78. 6d., by post 78. $10 d$.

Vol. IV. The West Coast, from Land's End to Mull of Galloway, including the East Coast of Ireland. Thirty Charts. Price 10s. 6d., by post 108. $10 d$.

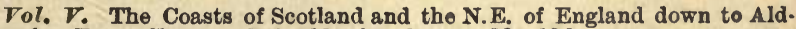
borough. Forty Charts. Price 108. 6d., by post 10s. $10 d$.

St. Bernard, The. Its History, Points, Breeding, and Rearing. By Huar DAt.TIRT. Illustrated with Coloured Frontispiece and Plates. In cloth, price $2 s 6 d .$, by post $28.9 d$.

St. Bernard Stud Book. Edited by Hugh DalzinL. Price 3s. 6d. each, by post 38. 9d. each.

$V o l$. $\boldsymbol{I}$. Pedigrees of 1278 of the best known Dogs traced to their mowt remote known ancestors, Show Record, \&c.

Vol. II. Pedigrees of 564 Dogs, Show Record, \&c.

Sea-Fishing for Amateurs. Practical Instructions to Visitors at Seaside Places for Catching Sea-Fish from Pier-heads, Sbore, or Boats, principally by means of Hand Lines, with a very useful List of Fishing Stations, the Fish to be caught there, and the Best Seasons. By FrANK HUDSON. Illustrated. In paper, price 18., by post 18. $2 d$.

Sea-Fishing on the English Coast. The Art of Making and Using SeaTackle, with a full account of the methods in vogue during each month of the year, and a Detailed Guide for Sea-Fishermen to all the most Popular Water. ing Places on the English Coast. By F. G. AFLALO. Illustrated. In cloth gilt, price $28.6 d$., by post $28.9 d$.

Sea-Life, Realities of. Describing the Duties, Prospects, and Pleasures of a Young Sailor in the Mercantile Marine. By H. E. ACRAMan Conte. With a Preface by J. R. DIGGLE, M.A., M.L.S.B. In cloth, price 3s. 6d., by post 3s. $10 d$.

Seaside Watering Places. A Description of the Holiday Resorts on the Coasts of England and Wales, the Channel Islands, and the Isle of Man, giving full particulars of them and their attractions, and all information likely to assist persons in selecting places in which to spend their Holidays according to their individual tastes. Illustrated. Twenty-second Year of Issue. Ready in May. In cloth, price $2 s .6 d .$, by post $2 s .10 d$. 
Sea Terms, a Dictionary of. For the use of Yachtsmen, Amateur Boatmen, and Beginners. By A. ANsted. Fully Illustrated. Cloth gilt, price 78. 6d. net, by post $78.11 d$.

Bhadow Entertainments, and How to Work them : being Something about Shadows, and the way to make them Prottable and Funny. By A. PATtre. sox. In paper, price 18., by post 18. $2 d$.

Shaye, An Easy: The Mysteries, Secrets, and Whole Art of, laid bare for 18., by post 18. 2d. Edited by Joseph MORTON.

Sheet Metal, Working in : Being Practical Instructions for Making and Mending Small Articles in Tin, Copper, Iron, Zinc, and Brass. Illustrated. Third Edition. By the Rev. J. LUKIN, B.A In paper, price 18., by post 18. $1 d$.

Shorthand, on Gurney's System (Improxed), LESSONS IN : Being Instructions in the Art of Shorthand Writing as used in the Service of the two Houses of Parliament. By R. E. MILLER. In paper, price 18., by post 18. $2 d$.

Shorthand, Exercises In, for Daily Half Hours, on a Newly-devised and Simple Method, free from the Labour of Learning. nlustrated. Being Part II. of "Lessons in Shorthand on Gurney's System (Improved)." By R. E. MILLER. In paper, price 9d., by post $10 d$.

Skating Cards: An Easy Method of Learning Figure Skating, as the Cards can be used on the Ice. In cloth case, 2s. 6d., bv post 28. 9d.; leather, 38. $6 d$., by post 38. 9d. A cheap form is issued printed on paper and made up as a small book, 18., by post 18. $1 d$.

Bleight of Hand. A Practical Manual of Legerdemain for Amateurs and Others. New Edition, Revised and Enlarged Profusely Illustrated. By E. SACHS. In eloth gilt, price 6s. $6 d$., by post $68.10 d$.

Enakes, Marsupials, and Birds. A Charming Book of Anecdotes, Adren. tures, and Zoological Notes. A capital Book for Boys. By ARTHUR Nicots, F.G.S., F.R.G.S., \&c. Ilustrated. In cloth gilt, price 38. 6d., by post 38. $10 d$.

Taxidermy, Practical. A Manual of Instruction to the Amateur in Collecting, Preserving, and Setting-up Natural IHistory Specimens of all kinds. With Examples and Working Diagrams. By Moxtagu BRowne, F.Z.S., Curator of Leicester Museum. Second Edition. In cloth gilt, price 7s. 6d., by post 78. $10 d$.

Thames Guide Book. From Lechlade to Richmond. For Boating Men, Anglers, Plcnic Parties, and all Pleasure-seekers on the River. Arranged on an entirely new plan. Socond Edition, profusely Illustrated. In cloth, price 18. $6 d$., by post 1s. $9 d$.

Tomato and Fruit Growing as an Industry for Women. Lectures given at the Forestry Exhibition, Earl's Court, during July and August, 1893. By Grace Harriman, Practical Fruit Grower and County Council Lecturer. In paper, price 18., by post 18. $1 d$.

Tomato Culture for Amateurs. A Practical and very Complete Mianual on the subject. By B. C. RAvenscroft. Illustrated. In paper, price 18., by post 18. $1 d$.

Trapping, Practical: Being some Papers on Traps and Trapping for Vermin, with a Chapter on General Bird Trapping and Snaring. By W. CARNEGIE. In paper, price 18., by post $18.2 d$.

Turning for Amateurs: Being Descriptions of the Lathe and its Attachments and Tools, with minute Instructions for their Effective Use on Wood, Metal, Ivory, and other Materials. Second Edition, Revised and Enlarged. By JAMEs LUKIN, B.A. Ulustrated with 144 Engravings. In cloth gilt, price 2s. $6 d .$, by post $28.9 d$.

Turning Lathes. A Manual for Technical Schools and Appientices. A Guide to Turning, Screw-cntting, Metal-spinning, \&c. Edited by JaMes LUkis, B.A. Third Edition. With 194 Illustrations. In cloth gilt, price 3., by post 38. 3d.

Yamp, How to. A Practical Guide to the Accompaniment of Songs by the Unskilled Musician. With Examples. In paper, price 9d., by post 10d.

Yegetable Culture for Amateurs. Containing Concise Directions for the Cultivation of Vegetables in small Gardens so as to insure Good Crops. With Lists of the Best Varieties of each ISort. By W. J. MAY Illustrated. In paper, price 18., by post $18.2 d$. 
Yentriloquism, Practical. A thoroughly reliable Guide to the Art of Voice Throwing and Vocal Mimicry, Vocal Instrumentation, Ventriloquial Figures, Entertaining, \&c. By ROBERT GANTHONY. Numerous Illustrations. In cloth gilt, price 28 . $6 d$., by post $28.9 d$.

Ylolins (Old) and their Makers: Including some References to those of Modern Tinies. By JAMES M. Fleming. Illustrated with Facsimiles of Tickets, Sound-Holes, \&c. In cloth gilt, price 68. $6 d$. nett, by post $68.10 d$.

Ylolin School, Practical, for Home Students. Instruetions and Exercises in Violin Playing, for the use of Amateurs, Self-learners, Teachers, and others. With a Supplement on "Easy Legato Studies for the Violin." By J. M. Fleming. Demy 4to, eloth gilt, price 9s. 6d., by post 10s. $2 d$. Without Supplement, price 78. $6 d$., by post 88 .

Yiyarium, The. Being a Full Description of the most Interesting Snakes, Lizards, and other Reptiles, and How to Keep Them Satisfactorily in Confinement. By REV. G. C. BATEMaN. Beautifully Illustrated. In cloth gilt, price $78.6 d$. nett, by post $8 s$.

War Medals and Decorations. A Manual for Collectors, with some account of Civil Rewards for Valour. Beautifully Illustrated. By D. HASTINGS IRWIN. In cloth gilt, price 78. 6d., by post $78.10 d$.

Whippet and Race-Dog, The: How to Breed, Rear, Train, Race, and Exhibit the Whippet, the Management of Raee Meetings, and OriginaI Plans of Courses. By Freeman LLOYd. In cloth gilt, price 3.6. $6 d$., by post 38. $10 d$.

Whist, Modern Sclentific. A. Practical Manual on new Lines, and with Illustrative Hands, printed in Colour. By C. J. Melrose. In cloth gilt, price 68 , by post $68.6 d$.

Wildfowling, Practical: A Book on Wildfowl in Wildfowl Shooting. By HY. SHARP. The result of 25 years' experience Wildfowl Shooting under all sorts of conditions of locality as well as circumstances. Profusely Illus. trated. Demy 8vo, cloth gilt, price 12s. 6d. nett, by post 12s. $10 d$.

Wild Sports in Ireland. Being Picturesque and Entertaining Descriptions of several visits paid to Ireland, with Practical Hints likely to be of service to the Angler, Wildfowler, and Yachtsman. By JOHN BICKERDYKE, Author of "The Book of the All-Round Angler," \&c. Beautifully Illustrated from Photographs taken by the Author. In cloth gilt, price 68., by post 68. $4 d$.

Window Ticket Writing: Containing full Instructions on the Method of Mixing and Using the Various Inks, \&c, required, Hints on Stencilling as applied to Ticket Writing, together with Lessons on Glass Writing, Japanning on Tin, \&c. Especially written for the use of Learners and Shop Assistants. By WM. C. ScoTr. In paper, price 18., by post 18. $2 d$.

Wire and Sheet Gauges of the World. Compared and Compiled by C. A. B. PFEILSCHMIDT, of Sheffield. In paper, price 18., by post 18. 1 d.

Wood Carying for Amateurs. Full Instructions for producing all the different varieties of Carvings. SECOND EDITION. Edited by D. DENNING. In paper, price 18., by post 18. $2 d$.

Workshop Makeshifts. Being a Collection of Practical Hints and Suggestions for the use of Amateur Workers in Wood and Metal. Fully Illustrated. By H. J. S. CASSALL. In cloth gilt, price $2 s .6 d .$, by post $2 s .9 d$.

\section{FICTION LIBRARY.}

Decameron of a Hypnotist. Tales of Dread. By E. SuFfling, Author of "The Story Hunter," \&c. With Illustrations. Cloth gilt, 38. 6d., by post 38. $10 d$.

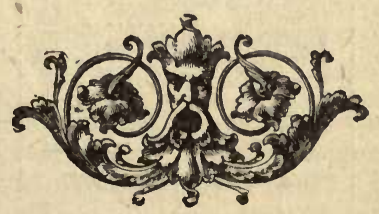




\section{CLASSIFICATION INDEX}

\section{PAGE. \\ ART.}

DEsigning ........... 4

OLD VIOLINS ......... 11

Painting..............

Perspective........... ?

VIOLIN SCHOOL........ 11

AMUSEMENTS.

Amateur ENTERTain.

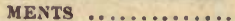
BuNKUM ENTERTAin. MENTS .............

Card Conjuring......

Card Tricks...........

Conjuriva........... 3, 10

GaMES .............. 5

Magic Lanterns......

Patience.............

POOL

SHADOW ENTERTAIN.

MENTS .............

SLEIGHT OF HAND ....

VAMPING .............

VENTRILOQUISM ......

WHIST ................

\section{COLLECTORS.}

AUTOGRAPH

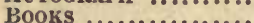

Corss ...............

ENGravings ..........

HANDWRITING ........

Library MaNUAL ....

Painters ...........

Postage Stamps ......

Postmarks

Pottery and Porce.

LAIN ...................

STAMPS OF EUROPE....

WAR MEDALS.........

\section{DOGS \& HORSES.}

BRRaKING Dogs

BRITISH DOGS ........

Colbie ................

DISEASES OF Dogs ..

Diseases of HoRses..

DOG-KEEPING

Fox TERrier .........

Grayhound ...........

HORSE-KEEPER $\ldots \ldots$

HoRSE-KEEPING ......

ST. BERNARD........

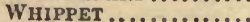

\section{FARM.}

Goat.KeEPING ......... PIG-KEEPING........... POUltry FARMING....
IGARDENING.

PAGE.

Begonia Culture ....

Bulb Cultue .........

Cactus Culture......

Carnation Culture ..

Chrysanthemum CUL

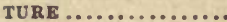

CUCUMBer CUlTUR ...

Dictionary .........

FERNS ................

Fruit Culture ......

Gardening in haYpt..

GRAPE Growing .......

Greenuouse Manage-

MENT . ...........

HARDY PERENila

HOME ...............

MUShROOM CULTURE..

OrCIIIDS ...............

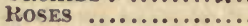

Tomato Cúture .... 10

Tomato Growing .... 10

Vegetable Culture.. 10

HOME.

A MERICAN DAINTIES .. COLD MEAT COOKERY.. COOKERY................ FANCY WORK.......... FISH, FLESH, \& FowL. HOME MEDICINE ......

MILLINERY ............

NeEdework DicTIONARY ............

SIIAVING ............ 10

\section{MECHANICS.}

BENT IRONWORK...... BOAT BUILDING ....... BOOKBINDING ......... Cabinet Making...... CANE Basket WORK .. FIREWORK MAKRig .. FRETWORK............. Marqueterie ......... MODEL YACHTS........ Piano Tuning ......... picture-Frame Mak. ING

SHEET METAL WORK... TICKET WRITING ...... TURNISG ............... TURNING LATHES...... WIRE GAUGES ........ WOOD CarVING ....... WoOd Polishes ....... WORKSHOP MAKESHIFTS .............

NATURAL HISTORY. AQUARIA .............
BEES ............ PAGE

Butterfies...........

DIRECTORY...............

HaWK Moths ........

SKETCHES ............

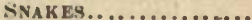

TAXIDERMY $\ldots \ldots \ldots \ldots$

VIVARIUM ...........

PETS.

British Birng........ Cagie BIRds' Diseases Canaries

Cats .....................

Feathered Friends...

FOREIGN BIRDS

GrEY PARROTS $\cdots . .$.

Guivea PIG ..........

MICR. . ..............

Moskeys ............

ParrakeEts ..........

PHEASANTS ............

RABBITS .............

SPEAKING PARRots....

10

10

11

\section{POULTRY \& PIGEONS.}

COLUMBarIUM ........ 3

Disfases..............

Fancy PIgeoss ......

INCUBATRRS ...........

haYiNg HENS..........

PIGEON-KEEPING ....

Poultry-Farmive ....

Poultry-IKEePINe ....

SPORT.

ANGLING ............ 1, 5 Bont Building ......... Bont SaILING ......... 2 CYCLING MAP........ 4, 9

FERRETS ............. Game Preserving... 5 SEA-FISHING .......... 1, 9

SKATINe ............. 10

TRAPPING ............ 10

WILDFOWIING ........ 11

WILd SPORTS......... 11

\section{TOURIST.}

FriEsLAND MERES

IN LA ND WATERING

Places.............

Mountaineering .....

ROAD CHART ...........

SAILING TOURS ..........

SEASIDE WATERING

Places..............

SOLENT GUIDE ..........

ThaMES Guide $\ldots \ldots .10$
5

6 7 
EXTRA SUPPLEMENTS Well Illustrated.

The Ladies', each Month, 1st Wed.; The Philatelists', 2nd Wed.: The Home, 3rd Wed.:

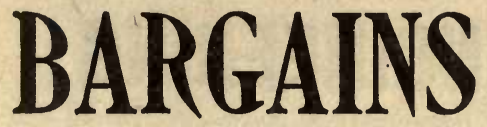

in Everything and Anything are readily secured through The Bazaar, Exchange and Mart Newspaper, which is used by Private Persons for disposing of things they no longer require. THE paper for Buying, Selling, and Exchanging by Private Persons.

TELEgRAMS: "BAzAAR, LONDON."

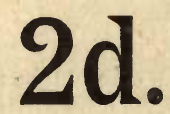

at

Newsagents.

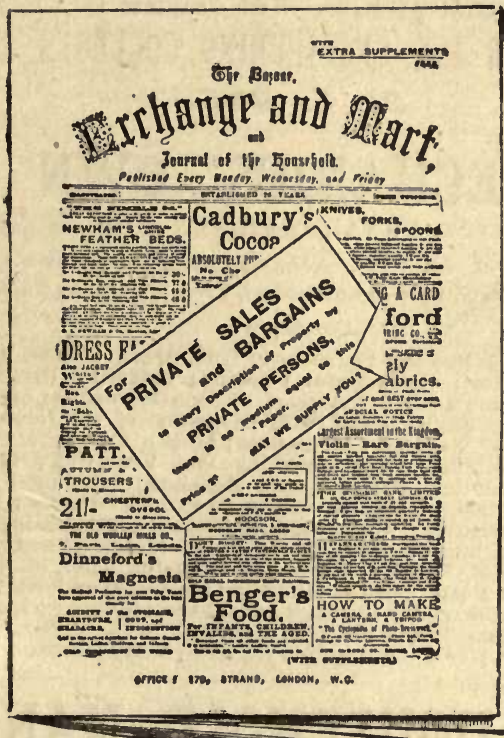

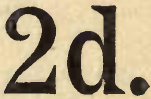

at

Bookstalls.

By post for 3 Stamps.

OFFICE: 170, STRAND, LONDON.

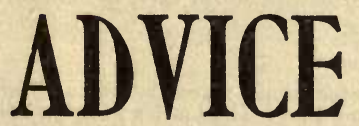

on every possible subject may be obtained on application to The Bazaar, Exchange and Mart, which has the largest staff of Eminent Experts of any paper in the Kingdom, and these Experts freely advise its readers. THE paper par excellence for Amateurs.

\section{EXTRA SUPPLEMENTS-continued.}

The Cyclists', each Month, 1st Mon. ; The Sportsman's, 2nd Mon. :-

The Garden, 3rd Mon.; The Dog Owners', Last Mon. 
Crown 4to, full gilt, fancy cloth, 478 pages Letterpress and 735 Engravings, price 7s. 6d.

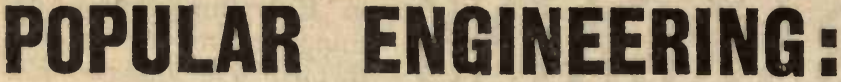

BEING INTERESTING AND INSTRUCTIVE EXAMPLES IN

CIVIL, MECHANICAL, ELECTRICAL, CHEMICAL, MINING, MILITARY, and NAVAL ENGINEERING.

GRAPHICALLY AND PLAINLY DESCRIBED AND

Specially Written for those about to enter the Engineering Profession and the Scientific Amateur. With Chapters npon

PERPETUAL MOTION and ENGINEBRING COLLEGES and SCHOOLS. BY F. DYE.

\section{SPONS' MECHANICS' OWN BOOK :}

A MANUAL FOR HANDICRAFTSMEN AND AMATEURS.

Complete in One large Vol., demy 8 vo, cloth, containing 700 pp. and 1420 Illustratiens.

Fourth Edition, 6s.; or half-bound, French morocco, 7s. 6d.

\section{Contents :}

Mechanical Drawing ; Casting and Founding in Iron, Brass, Bronze, and other Alloys; Forging and Finishing Iron; Sheet Metal Working; Soldering, Brazing, and Burning; Carpentry and Joinery, embracing descriptions of some 400 woods ; over $\angle 00$ Illustrations of Tools and their Uses; Explanations (with Diagrams) of 116 Joints and Hinges, and Details of Construction of Workshop Appliances; Rough Furniture, Garden and Yard Erections, and House-Building; Cabinet-making and Veneering; Carving and Fretcutting : Upholstery; Painting, Graining, and Marbling; Staining Furniture, Woods, Floors, and Fittings: Gilding, Dead and Bright, on various Grounds ; Polishing Marble, Metals and Wood; Varnishing; Mechanical Movements, illustrating contrivances for transmitting Motion; Turning in Wood and Metals : Masonry, embracing Stonework, Brickwork, Terra-cotts, and Concrete; Roofing with Thatch, Tiles, Slates, Felt, Zinc, \&c. ; Glazing with and without Putty, and Lead Glazing; Plastering and Whitewashing ; Paper. hanging ; Gas-fitting ; Bell-hanging, Ordinary and Electric Systems ; Lighting ; Warming; Ventilating ; Roads, Parements and Bridges; Hedges, Ditches andDrains ; Water Supply and Sanitation; Hints on House Construction suited to New Countries.

\section{SPONS' HOUSEHOLD MANUAL :}

\section{$\triangle$ TREASURY OF DOMESTIC RECEIPTS AND GUIDE FOR HOME MANAGEMENT.}

Demy 8vo, cloth, containing 957 pp. and 250 Illustrations, price 7s. 6d.; or half.bound

French morocco, 9s.

Principal Contents :

Hints for selecting a good House; Sanitation; Water Supply; Ventilation and Warm. ing; Lighting ; Furniture and Decoration; Thieves and Fire ; The Larder; Curing Foods for lengthened Preservation; The Dairy; The Cellar; The Pantry; The Kitchen; Receipts for Dishes; The Housewife's Room; Housekeeping, Narketing; The Dining: room; The Drawing-room; The Bed-room; The Nursery; The Sick-room; The Bath. room; The Laundry; The School-room; The Playground; The Work-room; The Library; The Garden ; The Farmyard ; Small Motors; Household Law.

Iondon: I. \& F. N. SPON, Itd., 125, Strand. New York: SPON \& CHAMBEIUAIN, 12, Cortlandt Street. 


\section{POST FREE 1s, 1d. EACH.}

Allments of Poultry. By F. T. BARTON.

tHorses. The Gentleman's Guide. By JaMres MrLLs, M.V.C.S. With suggestions relative to the treatment of Diseases of Horses, and the Art of Horsemanship, by RAREY. 21st Edition.

*Kennel Companion and Referee By DR. Gordon Stables. Illustrated.

*Pet Animals ; or, the Amateur's Zoo. Their Habits, Characteristies, and How to Manage them in Captivity. By ArThUR PA Trisrsor. With 40 Illustrations.

tThe British Aviary; or, Song Birds. Containing Addenda on the various breeds of Canaries. BY THOMA8 ANDREWs. Coloured Frontispiece.

*Canaries. How to Breed, Rear, and Keep them in Health. With pictures of nineteen varieties, and chapter on Mules. By KA RL Russ.

tParrots, Cockatoos, \&c. By Captain Brown. Forty Illustrations, by JOSEPH P. KIDD.

tCage Birds. By Bechstein (including Parrots). Fifty-six Illustrations. Edited by H. G. ADA MS.

†Rabbit Keeper's Guide. How best to Rear, Feed, and Keep the several kinds of Rabbits.

*Pigeons. Their Varieties, Treatment, Breeding, and Diseases. By EDWARD BROw:, F.L.S. Illustrated by LUDLOw.

*Poultry. Their Varieties, Breeding, and Diseases. By EDWARD Brown, F.L.S. Twenty-four Illnatrations by LUDLOW.

Sheep. Their Varieties, Points, and Characteristics. BY JOSEPH DaRBY.

Cookery Made Easy. By a Lady. With Coloured Plates. 24th Edition.

Confectionery, Pastry, Preserving Sweets, \&e. By George ReID.

${ }^{*}$ Card Tricks and Conjuring Up-to-Date. By Hercat.

Fireworks and Chemical Surprises, By Charles Gilbert.

Crown 8vo. Illustrated. "Bound in Illustrated stiff varnished paper covers. + Bound in Illustrated stiff paper covers, $¥$ Cloth bound, gilt lettering.

LONDON: DEAN \& SON, LIMITED, 160a, FLEET ST., E.C.

Entirely New Edition-Now Ready,

Showing the Very Latest Changes. JOHNSTON'S

"MODERN" LBBRARY MAP of ENGLLND \& WALES.

\section{SIZE 68in. by 54 in.}

On Cloth, Mahogany Rollers, bound with Silk up the sides, and Varnished, price £1 7s. 6d.; on Cloth, Stained Wood Rollers, and Varnished, price $£ 1$ 1s.; also in 4 Sheets, size 35 in. by $29 \frac{1}{2}$ in., each price 2s. per sheet in Cloth Case; or 3s. 6d. per sheet on Cloth to fold, and in Cloth Case.

\section{Also Third Edition, \\ W. \& A. K. JOHNSTON'S}

RAILWAY \& CANAL MAP OF ENGLAND \& WALES,

Showing each Railway System in a particular colour and marking. Size, $50 \mathrm{in}$. by $42 \mathrm{in}$. Price, in two sheets, 7s. 6d.; on Cloth, Rollers, and Varnished, 10s.; on Cloth to fold in Titled Cloth Case, $10 \mathrm{s.}$

\section{W. \& A. K. JOHNSTON,}

Edina Works, Easter Road, and 7, Hanover Street, EDINBURGH ;

5, White Hart Street, Warwick Lane, London, E.C. 


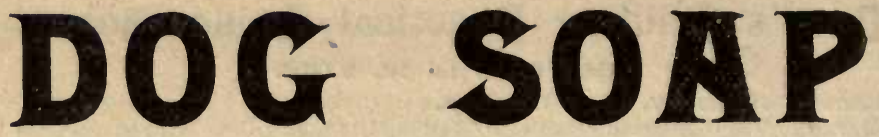

MADE BY

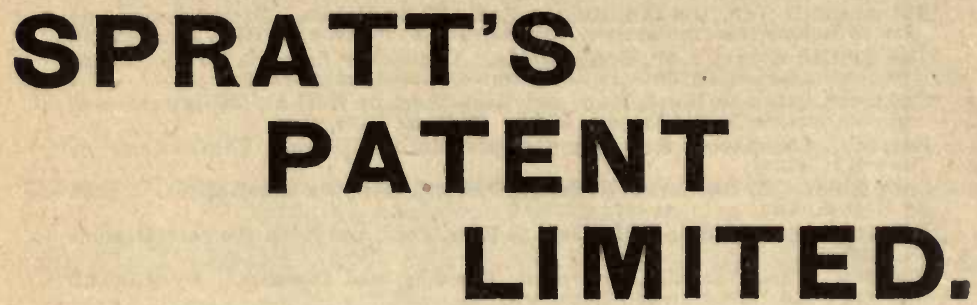

\section{A NON-POISONOUS PREPARATION.}

Invaluable for Preparing the Coat for Exhibition. SOLD IN TABLETS.

\section{DOG MEDICINES.}

Alterative Cooling Powders

Aperient Tasteless Biscuits

Chronic Skin Disease Care

Cough Pills

Chemical Food

Chorea Pills (St. Vitus' Dance)

Diarrhœa Mixture

Distemper Powders

Distemper Pills

Disinfectant for Kennels

Ear Canker Lotion

Eczema Lotion

Eye Lotion

Hair Stimulant
Jaundice or "Yellows" Pills

Locurium Oil (Patent) for Animal Use

Locurium Oil (Patent) for Human Use (including Govern. ment Stamp)

Mange Lotion

Parging Pills

Rhenmatic and Sprain Liniment

Rheumatic and Chest Founder Pills

Tonic Condition Pills

Vegetable Puppy Vermifuge

Worm Powders

Worm Pills

YOUR TRADESMAN OR STORES WILL SUPPLY YOU. Spratt's Patent Limited, Bermondsey, London, S.E. PAMPHLET ON CANINE DISEASES, POST FREE. 
280

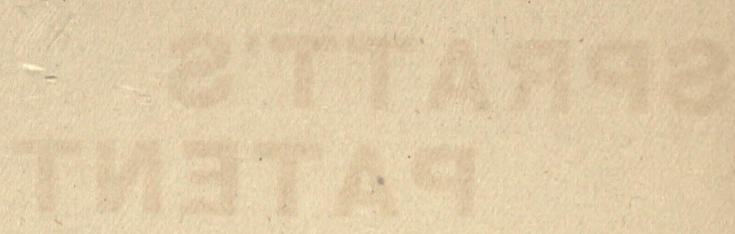

ahom

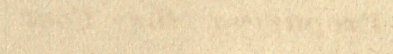

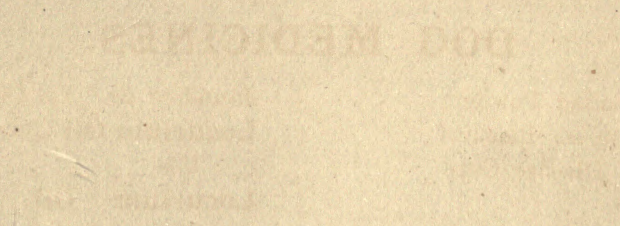

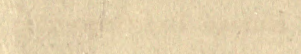
l

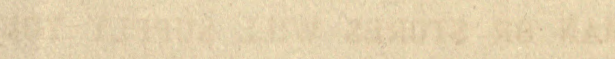

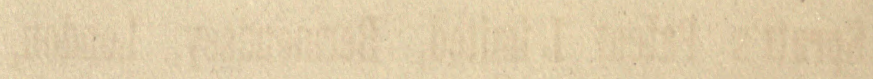

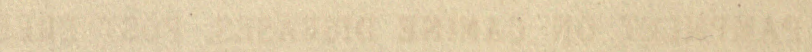






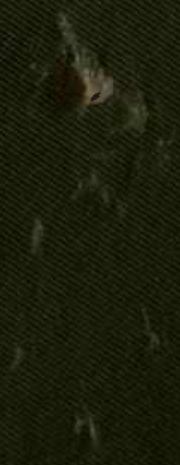

